\title{
ZUSGS
}

\section{Geologic Map of the State of Hawai'i}

By David R. Sherrod, John M. Sinton, Sarah E. Watkins, and Kelly M. Brunt

Pamphlet to accompany

Scientific Investigations Map 3143

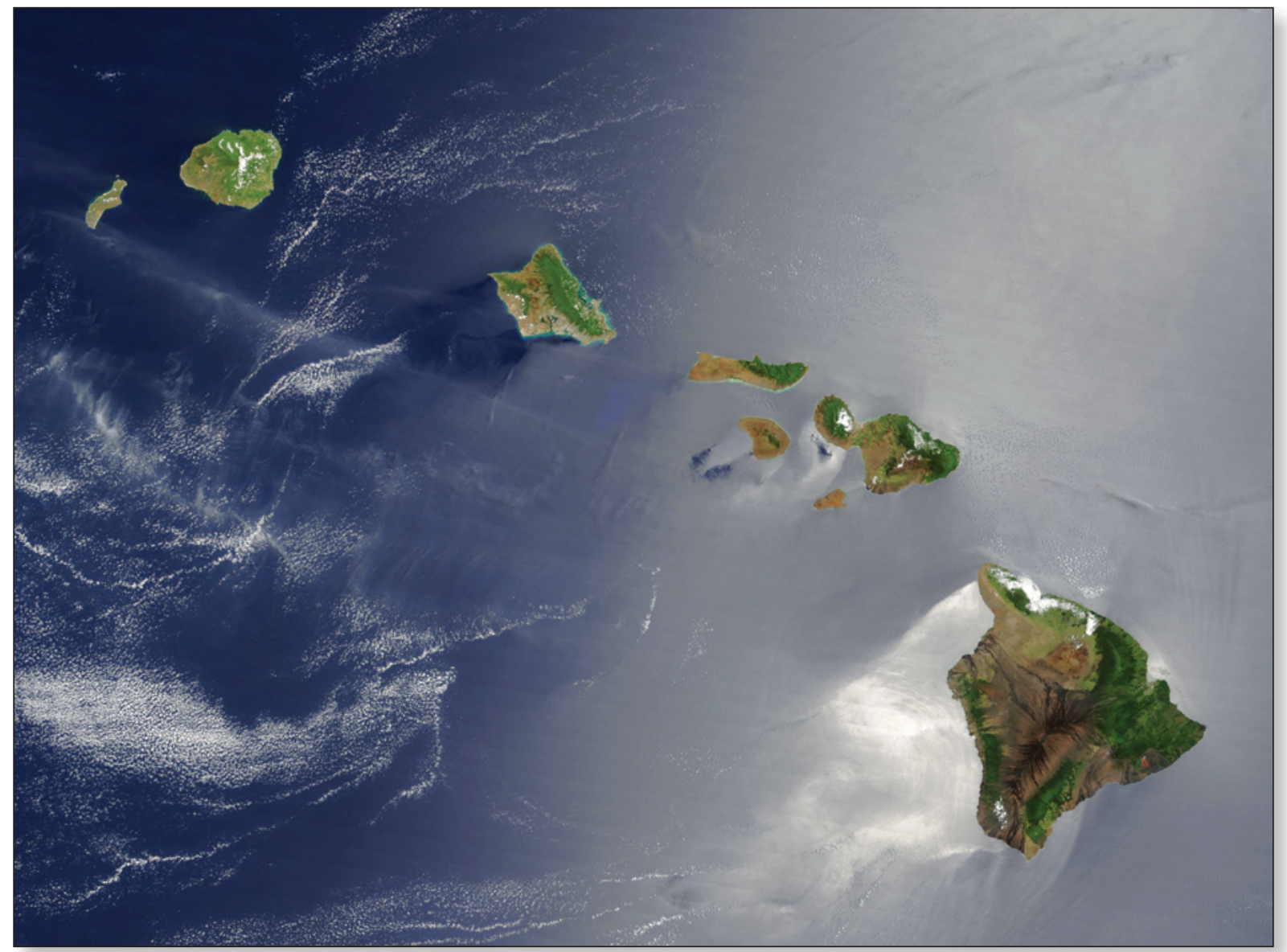

2021

U.S. Department of the Interior

U.S. Geological Survey 


\section{U.S. Geological Survey, Reston, Virginia: 2021}

For more information on the USGS — the Federal source for science about the Earth, its natural and living resources, natural hazards, and the environment-visit https://www.usgs.gov or call 1-888-ASK-USGS.

For an overview of USGS information products, including maps, imagery, and publications, visit https://store.usgs.gov.

Any use of trade, firm, or product names is for descriptive purposes only and does not imply endorsement by the U.S. Government.

Although this information product, for the most part, is in the public domain, it also may contain copyrighted materials as noted in the text. Permission to reproduce copyrighted items must be secured from the copyright owner.

Suggested citation:

Sherrod, D.R., Sinton, J.M., Watkins, S.E., and Brunt, K.M., 2021, Geologic map of the State of Hawai'i: U.S. Geological Survey Scientific Investigations Map 3143, pamphlet 72 p., 5 sheets, scales 1:100,000 and 1:250,000, https://doi.org/10.3133/sim3143.

Associated data for this publication: Sherrod, D.R., Robinson, J.E., Sinton, J.M., Watkins, S.E., and Brunt, K.M., 2021, Geologic map database to accompany geologic map of the State of Hawaii: U.S. Geological Survey data release, https://doi.org/10.5066/P9YWXT41.

ISSN 2932-1311 (print)

ISSN 2932-132X (online)

Cover. True-color moderate resolution imaging spectroradiometer (MODIS) satellite image 05292003 showing the eight principal islands of the Hawaiian Island chain from May 21, 2003. Distance from Island of Ni'ihau (farthest west) to the eastern tip of the Island of Hawai'i is $620 \mathrm{~km}$. The northeast sides of the islands receive more rain owing to prevailing trade winds; green hues of vegetation thus are generally more expansive there than on the leeward sides. Areas above about 7,000 ft altitude are arid and vegetation poor. Island of Hawai'i, the largest of the eight islands, shows reddish heat spot on Kīlauea Volcano, in its southeast corner, taken from the thermal channel of the MODIS instrument and composited onto the image. Satellite image is courtesy of MODIS Land Rapid Response Team, https://visibleearth.nasa.gov/. 


\section{Contents}

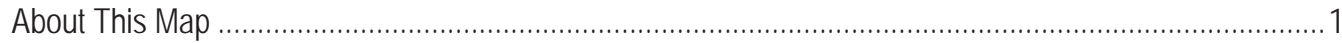

Sources of Mapping, Methods of Compilation, Origin of Stratigraphic Names, and Divisions of the

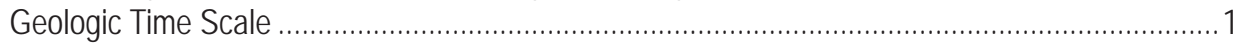

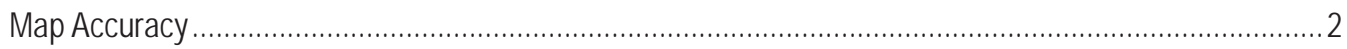

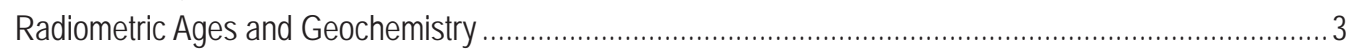

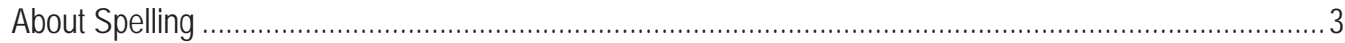

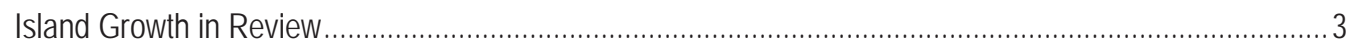

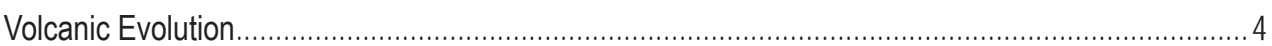

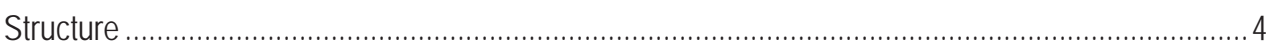

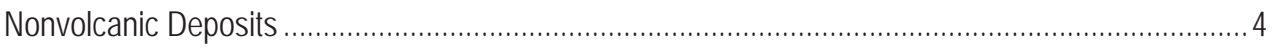

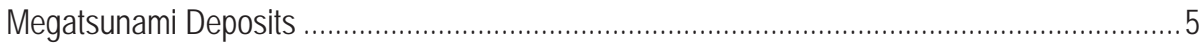

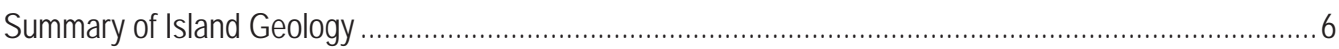

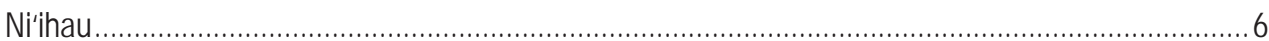

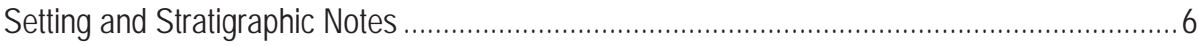

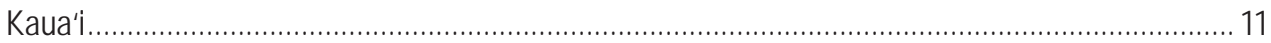

Setting and Stratigraphic Notes ......................................................................... 11

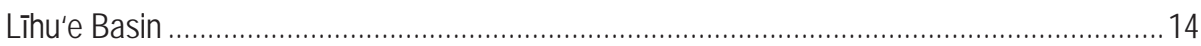

Two Shields or One?

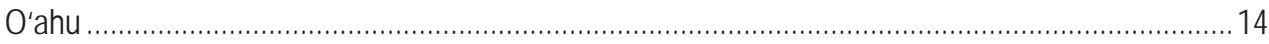

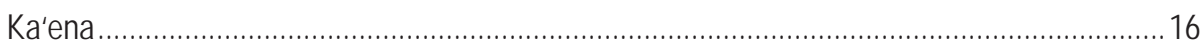

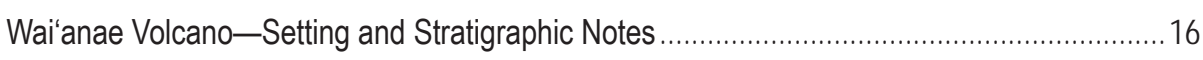

Ko'olau Volcano-Setting and Stratigraphic Notes...........................................................19

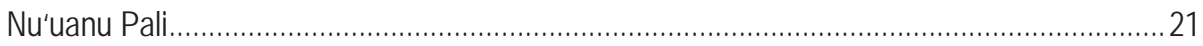

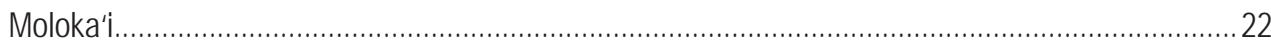

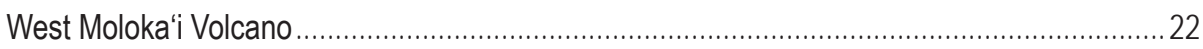

East Moloka'i Volcano

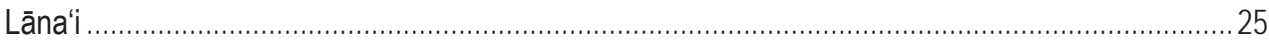

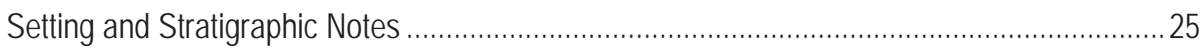

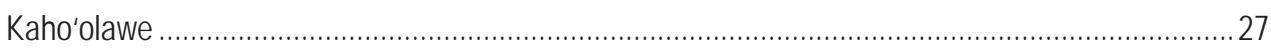

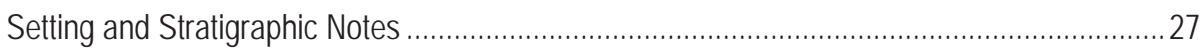

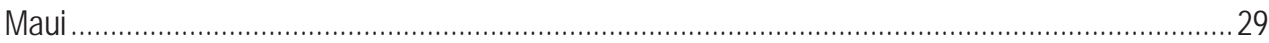

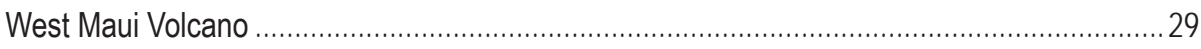

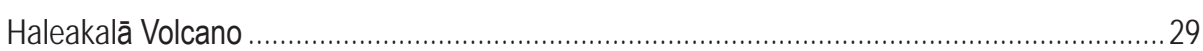

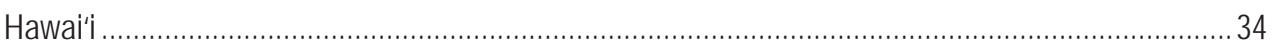

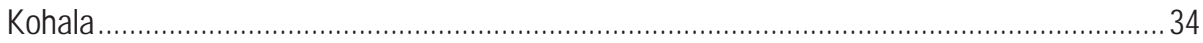

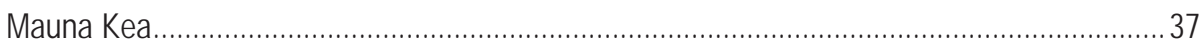

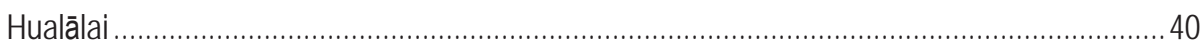

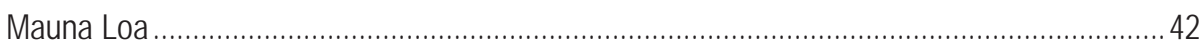

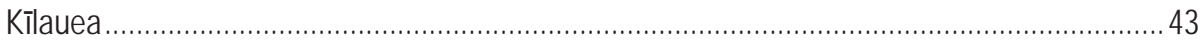

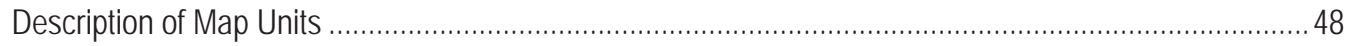

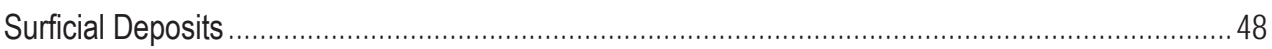

Volcanic and Intrusive Rocks on the Island of Ni ihau .............................................................. 50

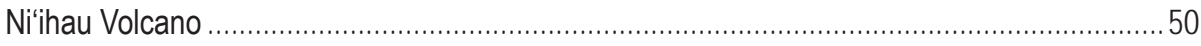

Volcanic and Intrusive Rocks on the Island of Kaua'i .......................................................

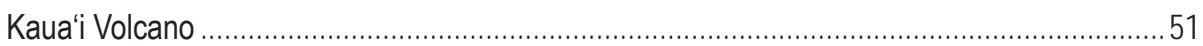

Volcanic and Intrusive Rocks on the Island of O'ahu................................................................5

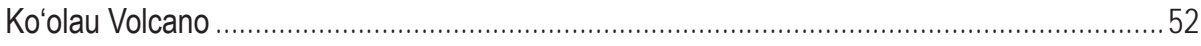

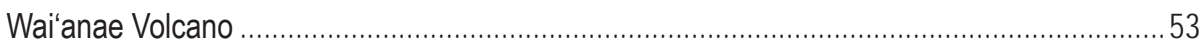




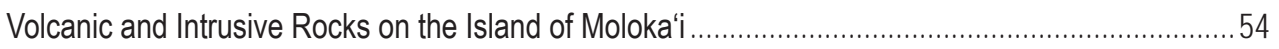

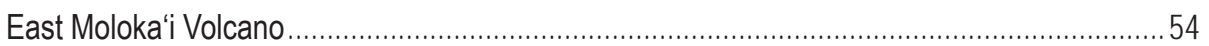

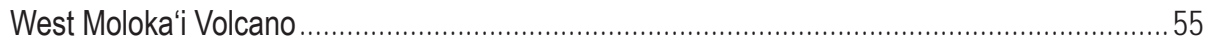

Volcanic and Intrusive Rocks on the Island of Lāna'i............................................................56

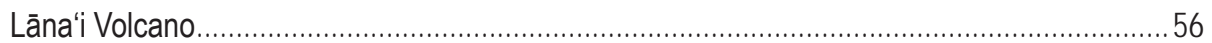

Volcanic and Intrusive Rocks on the Island of Kaho'olawe.................................................57

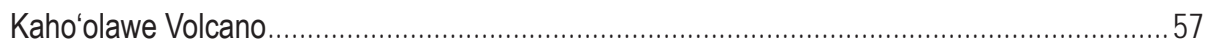

Volcanic and Intrusive Rocks on the Island of Maui .........................................................5

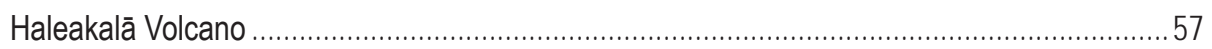

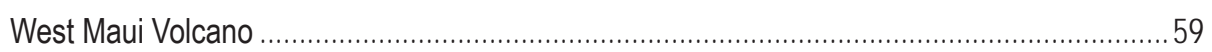

Volcanic and Intrusive Rocks on the Island of Hawaili..........................................................5

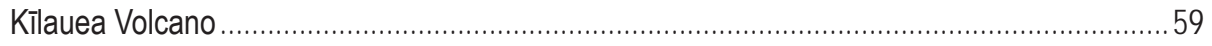

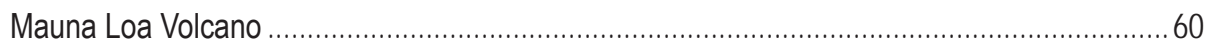

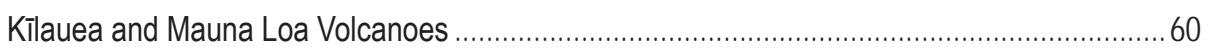

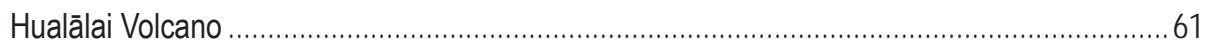

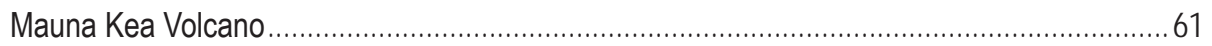

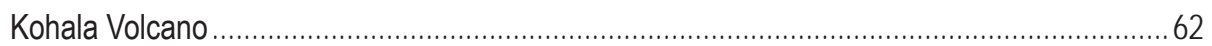

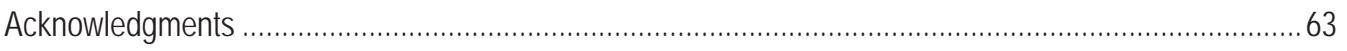

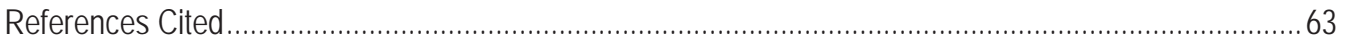

Appendix 1. Information About the Recalculating of Radiometric Ages for Hawai'i State Geologic Map.......... 72

\section{Figures}

1. Chief sources of mapping used in compilation of geologic map of State of Hawai'i ..................2

2. Alkali-silica diagram $\left(\mathrm{Na}_{2} \mathrm{O}+\mathrm{K}_{2} \mathrm{O}\right.$ versus $\mathrm{SiO}_{2}$ ) composited from several volcanoes ................... 5

3. Geologic map of Nithau, generalized from this publication's digital map database ................... 7

4. Radiometric ages for geologic units on Nithau and Kaua'i..................................................10

5. Alkali-silica $\left(\mathrm{Na}_{2} \mathrm{O}+\mathrm{K}_{2} \mathrm{O}\right.$ versus $\left.\mathrm{SiO}_{2}\right)$ diagram for analyzed rocks from Nithau...................... 10

6. Geologic map of Kaua'i, generalized from this publication's digital map database ..................12

7. Alkali-silica $\left(\mathrm{Na}_{2} \mathrm{O}+\mathrm{K}_{2} \mathrm{O}\right.$ versus $\left.\mathrm{SiO}_{2}\right)$ diagram for analyzed rocks from Kaua'i....................... 13

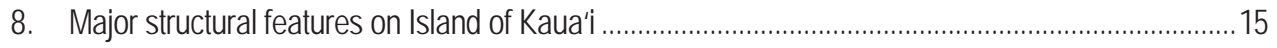

9. Geologic map of O'ahu, generalized from this publication's digital map database ....................17

10. Radiometric ages from Wai'anae volcano, Island of O'ahu .................................................... 18

11. Alkali-silica $\left(\mathrm{Na}_{2} \mathrm{O}+\mathrm{K}_{2} \mathrm{O}\right.$ versus $\left.\mathrm{SiO}_{2}\right)$ diagram for analyzed rocks from Wai'anae volcano, O'ahu....19

12. Alkali-silica $\left(\mathrm{Na}_{2} \mathrm{O}+\mathrm{K}_{2} \mathrm{O}\right.$ versus $\left.\mathrm{SiO}_{2}\right)$ diagram for analyzed rocks from Ko'olau volcano, O'ahu.......20

13. Radiometric ages from Ko'olau volcano, O'ahu .................................................................. 21

14. Geologic map of Moloka'i, generalized from this publication's digital map database....................23

15. Alkali-silica $\left(\mathrm{Na}_{2} \mathrm{O}+\mathrm{K}_{2} \mathrm{O}\right.$ versus $\left.\mathrm{SiO}_{2}\right)$ diagram for analyzed rocks from Moloka'i. .................... 24

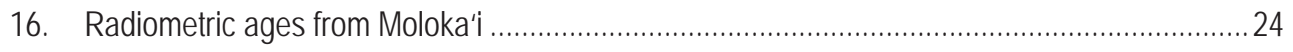

17. Geologic map of Lāna'i, generalized from this publication's digital map database ....................25

18. Alkali-silica $\left(\mathrm{Na}_{2} \mathrm{O}+\mathrm{K}_{2} \mathrm{O}\right.$ versus $\left.\mathrm{SiO}_{2}\right)$ diagram for analyzed rocks from Lāna'i ........................ 26

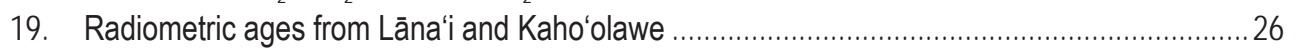

20. Geologic map of Kaho'olawe, generalized from this publication's digital map database ..................27

21. Alkali-silica $\left(\mathrm{Na}_{2} \mathrm{O}+\mathrm{K}_{2} \mathrm{O}\right.$ versus $\left.\mathrm{SiO}_{2}\right)$ diagram for analyzed rocks from Kaho'olawe ................28

22. Geologic map of Maui, generalized from this publication's digital map database ....................30

23. Alkali-silica $\left(\mathrm{Na}_{2} \mathrm{O}+\mathrm{K}_{2} \mathrm{O}\right.$ versus $\left.\mathrm{SiO}_{2}\right)$ diagram for analyzed rocks from West Maui................... 31

24. Radiometric ages from West Maui volcano ………............................................................ 31 
25. Alkali-silica $\left(\mathrm{Na}_{2} \mathrm{O}+\mathrm{K}_{2} \mathrm{O}\right.$ versus $\left.\mathrm{SiO}_{2}\right)$ diagram for analyzed rocks from Haleakalā volcano,

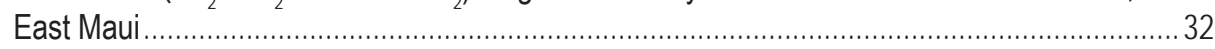

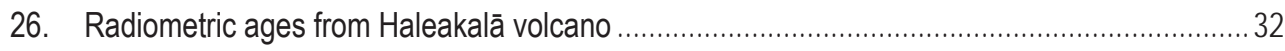

27. Map showing strata of the Hāna Volcanics, on Maui, by age ................................................33

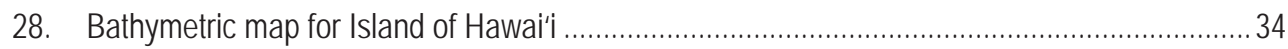

29. Map showing stratigraphic formations for volcanoes on Island of Hawaili.................................35

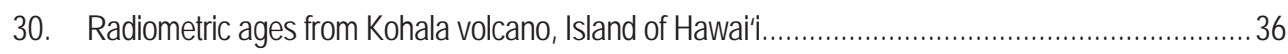

31. Alkali-silica $\left(\mathrm{Na}_{2} \mathrm{O}+\mathrm{K}_{2} \mathrm{O}\right.$ versus $\left.\mathrm{SiO}_{2}\right)$ diagram for analyzed rocks from Kohala volcano, Island of Hawaiti.

32. Alkali-silica $\left(\mathrm{Na}_{2} \mathrm{O}+\mathrm{K}_{2} \mathrm{O}\right.$ versus $\left.\mathrm{SiO}_{2}\right)$ diagram for rocks from Mauna Kea volcano, Island of Hawai'i, as sampled at the surface and in Hilo drill hole ........................................................... 38

33. Potassium-argon ages from Mauna Kea's surface volcanic rocks .......................................39

34. Calibrated ages from charcoal beneath Holocene volcanic rocks, Mauna Kea volcano,

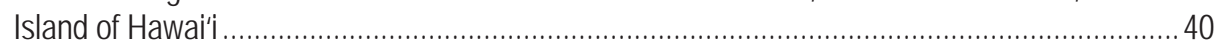

35. Distribution of volcanic rocks by age for Hualälai, Mauna Loa, and Kïlauea volcanoes, Island

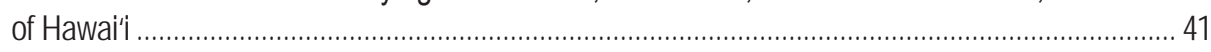

36. Alkali-silica $\left(\mathrm{Na}_{2} \mathrm{O}+\mathrm{K}_{2} \mathrm{O}\right.$ versus $\left.\mathrm{SiO}_{2}\right)$ diagram for analyzed rocks from Hualälai volcano, Island of Hawaili.

37. Radiometric ages from lava flows in the Ninole Basalt ..........................................................4

38. Radiometric ages from early alkalic volcanic rocks on Kïlauea's submarine flank and from tholeitic lava in $\mathrm{SOH}-1$ and $\mathrm{SOH}-4$ drill holes . .44

39. Alkali-silica $\left(\mathrm{Na}_{2} \mathrm{O}+\mathrm{K}_{2} \mathrm{O}\right.$ versus $\left.\mathrm{SiO}_{2}\right)$ diagram for analyzed rocks from Kïlauea Volcano sampled in $\mathrm{SOH}-1$ drill hole and offshore submarine setting...

40. Exposure of well-dated Puna Basalt sequence and underlying thick tephra deposits (Pāhala Ash), Nanahu arroyo .............................................................................................. 46

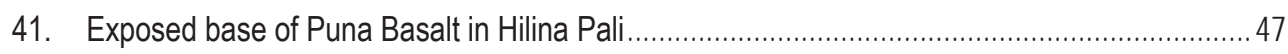

42. Escarpment-mantling lava flows and positioning of faults ................................................. 48

\section{Tables}

1. Potassium-argon ages for Pānit'au and Ki'eki'e Basalts, Island of Ni'ihau, Hawai'í....................8

2. Radiocarbon ages to determine rate of stratigraphic accumulation and age at base of Puna Basalt in Hilina Pali, Kīlauea Volcano, Hawaíi. 


\title{
Geologic Map of the State of Hawai'i
}

\author{
By David R. Sherrod, John M. Sinton, Sarah E. Watkins, and Kelly M. Brunt
}

\section{About This Map}

This geologic map and its digital databases present the geology of the eight major islands of the State of Hawai' $i$. The map should serve as a useful guide to anyone studying the geologic setting and history of Hawai $i$, including ground- and surface-water resources, economic deposits, and landslide or volcanic hazards. Its presentation in digital format allows the rapid application of geologic knowledge when conducting field work; analyzing land-use or engineering problems; studying onshore or nearshore biologic communities; or simply understanding the relation between the geology, scenery, and cultural history of the Hawaiian paradise.

The map includes a Description of Map Units, which describes the lithologic characteristics and distribution of the geologic deposits. A Correlation of Map Units shows how the different geologic formations are related to each other stratigraphically. A fairly complete geospatial database of the radiometric ages and geochemical analyses has been compiled from findings published over the past 100 years by numerous Earth scientists working across the island chain. The digital map, analytical databases, and metadata may be downloaded from the U.S. Geological Survey's publication website at https://doi.org/10.3133/sim3143.

\section{Sources of Mapping, Methods of Compilation, Origin of Stratigraphic Names, and Divisions of the Geologic Time Scale}

The geologic map of Hawai'i relies heavily on the mapping by Harold Stearns and Gordon Macdonald done in the 1930s, 1940s, and 1950s for Ni'ihau, Kaua'i, Moloka'i, Lāna'i, Kaho'olawe, much of O'ahu, and West Maui (fig. 1). Their seminal publications have been out of print for decades and are available only in a few libraries and private collections. Recently the text for each has been transferred into portable document format and may be downloaded from the U.S. Geological Survey (USGS) publication website (specifically http://pubs.usgs.gov/ misc_reports/stearns, last visited February 2020). Map plates that accompanied those publications have been scanned and made available at the National Geologic Map Database website (ngmdb. usgs.gov). We add to this map our own mapping for west $\mathrm{O}^{\text {'ahu }}$ and West Moloka'i (J.M. Sinton) and East Maui (D.R. Sherrod).
The Island of Hawai' $i$ has fared better than the rest of the state with regard to readily available mapping in recent years, owing to a map that brought a vast improvement in detail for the five subaerial volcanoes there (Wolfe and Morris, 1996a). On our statewide map we utilize the Wolfe and Morris (1996a) geologic depiction of the Island of Hawai'i as it was made available electronically (Trusdell and others, 2006). The Hawai'i Island mapping is revised herein to show lava flows emplaced in the past 20 years on Kīlauea Volcano (unpub. data, current as of 2019, Hawaiian Volcano Observatory, U.S. Geological Survey) and a few other minor changes discussed later.

The decision to use legacy mapping as our depiction for several of the islands instead of undertaking new field work stems partly from the lack of resources and the pressing need for a digital geologic map but also from the notable insight contained in the earlier geologic mapping for many areas. Those maps carry an inherent problem, however-the inaccuracy associated with their topographic base maps. Hawai'i's first topographic maps were produced early in the twentieth century, before the advent of more precise tools like aerial photography and photogrammetry. Many parts of the state were remote or inaccessible when the first topographic base maps were made; consequently the maps were, in some areas, only generalized renditions. These shortcomings were recognized and described tersely on occasion. For example, H.T. Stearns (in Stearns and Macdonald, 1947, p. 19) described how "Detailed traverses were made up each tributary of Wailau and Pelekunu streams [on Moloka'i], but the results could not be plotted on the topographic base map because the stream pattern shown on the map is seriously in error." Such was the world when Harold Stearns began his phenomenal geologic march across the island chain in the 1930s, an effort that culminated when Gordon Macdonald and his team published the Kaua'i geologic map in 1960.

Another source of discrepancy arises simply because the geographic setting of the Hawaiian island chain, as a map projection problem, was not as well known as now through modern geodesy. For example, an intracanyon lava flow, correctly depicted within its canyon on the older maps, may well be shifted geographically to a ridge top when digitized and recast unwittingly onto a modern topographic map. Therefore, when making this map, the boundary of every geologic unit shown on older maps had to be reinterpreted in order to display properly on modern 1:24,000-scale topographic quadrangle maps. Compilation was straightforward where newer geologic mapping was available, as was the case for west $\mathrm{O}^{\text {‘ } a h u, \text { Moloka }} \mathrm{i}$, East Maui, and the Island of Hawai' $i$. 


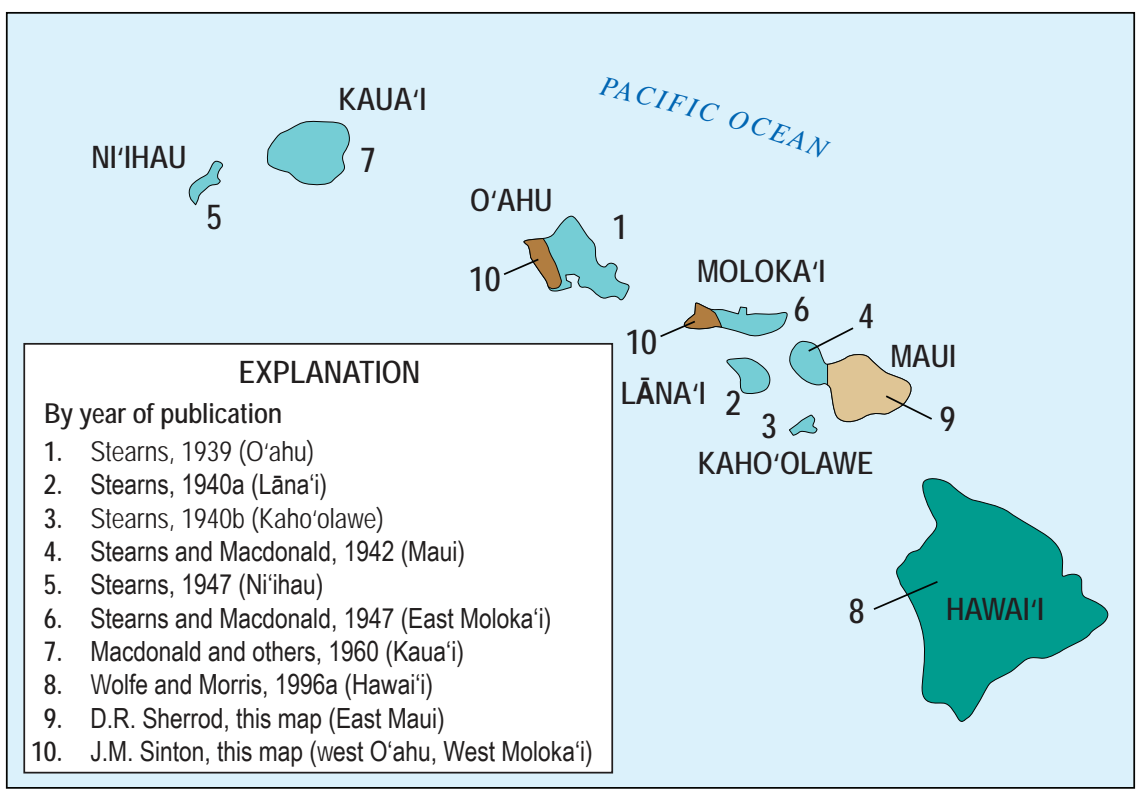

Figure 1. Chief sources of mapping used in compilation of geologic map of State of Hawai'i. See References Cited for full bibliographic citations. Pale green shading represents geologic mapping published before the 1970s; darker green, in the 1990s; brown, published as this map.

In some cases, we have modified the older geologic maps by showing a few geologic map units lacking on the legacy map plates but found on generalized figures within the monographs that described those maps. We have chosen to incorporate as much of that geologic knowledge as possible, especially where the geologic interpretation has been borne out by subsequent chemical analyses and where the old map figures were prepared so carefully that contacts can be traced accurately; for example, some lava flows on the Haleakalā's north slope (East Maui). We view our map as a guide to future research and have attempted to include as much substantive information as available to us.

The stratigraphic names of nearly all major volcanic units on the Hawaiian Islands were formalized long ago. A revision of those names was undertaken by Langenheim and Clague (1987) to meet changing national standards and to keep the naming straightforward. We follow the Langenheim and Clague usage explicitly. For west $\mathrm{O}^{`}$ ahu, we rely upon a revision to the stratigraphic nomenclature of the Wai'anae volcano (Sinton, 1987; Presley and others, 1997), and for West Moloka 'i we adopt the stratigraphic revisions of Sinton and others (2017). Volcanic formations on the Island of Hawai' $i$ are unchanged from their representation by Wolfe and Morris (1996a), which modified the Langenheim and Clague usage only by using the more inclusive name Pololū Volcanics for the oldest strata at Kohala volcano, which are slightly more diverse than basalt.

The time scale used herein is that published by the International Commission on Stratigraphy (Gradstein and others, 2004). A prominent change pertinent to our discussion of Hawaiian geology is the revision of the Pleistocene-Holocene boundary to $11,500 \mathrm{yr}$ before present (yr before A.D. 1950). This change results from calibrating to sidereal years the long-established 10,000-yr radiocarbon age (Gibbard and Van Kolfschoten, 2004). The accepted age of the Pliocene-Pleistocene boundary changed during the production of this map (2.58 million years ago [Ma]; Gibbard and others, 2010), a revision we adopted as this map was entering publication. The Miocene-Pliocene boundary is $5.33 \mathrm{Ma}$. Minor revisions to chron boundaries in the geomagnetic-polarity time scale are also incorporated (Ogg and Smith, 2004).

\section{Map Accuracy}

Accuracy ranges widely across the map. For most of the islands, contacts should be considered "approximately located," with standard error of $100 \mathrm{~m}$ (plus or minus $50 \mathrm{~m}$ ). This estimate allows for the vagaries associated with the change from an antiquated topographic base to a modern base for most of the islands. It also has some basis in the old saying, "accuracy is commonly a millimeter at the presentation scale of the map," from which a 100-m error estimate corresponds to the 1:100,000 scale of the Island of Hawai'i geologic map (Wolfe and Morris, 1996a). We found during limited field testing on Kaua' $i$ and West Maui that the accuracy is generally well within that limit, commonly better than $50 \mathrm{~m}$-perhaps surprising in view of the geographic fitting undertaken for the legacy maps, the locally forbidding nature of the Hawaiian landscape faced by any field worker, and the commonly poor geologic exposure encountered during field work both then and now. The geology for the Island of Hawai' $i$ (from Wolfe and Morris, 1996a) retains an accuracy of plus-or-minus $50 \mathrm{~m}$ overall. The new mapping from west $\mathrm{O}^{`}$ ahu, West Moloka' $\mathrm{i}$, and East Maui ranges in accuracy from 15 to $50 \mathrm{~m}$. No effort has been made to further classify the accuracy or precision of linework.

One other caveat is offered. We adapted the older published maps, originally published at scale 1:62,500, to portray suitably at 1:24,000 scale, the only series of topographic maps for entire-state coverage at large or intermediate scale when we began our work. (The U.S. Geological Survey's 100,000scale topographic maps are unfinished for some islands, and the 1:250,000-scale maps are too generalized for many purposes). By fitting contacts to large-scale topographic depictions, we have added an apparent precision perhaps unwarranted by the accuracy available in the published data.

No estimate of accuracy is assigned to the presentation of the numerous dikes and sparse sills shown for several of the islands. Dikes in the State of Hawai'i typically lack topographic expression. Consequently we had few clues to aid in fitting the 
older geologic rendition to modern base maps. The dike coverage should be considered a schematic representation derived from the published depictions, useful for studying dike trends and abundance and their relation to rift zones on eroded volcanoes.

\section{Radiometric Ages and Geochemistry}

As part of our map depiction we compiled GIS (geographic information system) layers showing radiometric ages and wholerock geochemical analyses from the published literature and a few unpublished sources for all the islands except Hawai'i. For the Island of Hawai' $i$, the substantial presentation by Wolfe and Morris (1996b), with its 1,786 major-element analyses, proved sufficient for our purposes. All these databases have been static in the years following the 2007 preliminary publication of this report.

Potassium-argon ages obtained prior to 1977 were recalculated to conform to a change in international standards for the isotopic abundance and decay rates (Steiger and Jäger, 1977). For consistency, all ages are reported herein with their twosigma (95 percent) confidence interval, the method adopted increasingly as new ages are reported. Analytical error was not reported directly for some seminal ages reported by McDougall (1964), but his text was sufficiently detailed to allow for their calculation, the results of which are included herein. The digital database for ages includes one- and two-sigma error for all the $\mathrm{K}$-Ar and ${ }^{40} \mathrm{Ar}^{/ 39} \mathrm{Ar}$ ages, as well as an indication of how the data were reported originally. See appendix 1 for additional comments about the radiometric dating database.

Radiocarbon ages representing volcanic events are an important part of the geochronologic record for East Maui (Haleakalā) and most of the volcanoes on the Island of Hawai' $i$. These ages are customarily reported as "raw data"; that is, in radiocarbon years before present (before A.D. 1950) and with one-sigma confidence interval, and so they are shown in the digital database. However, for purposes of discussion in our explanatory text and description of map units, we calibrate the ages to sidereal years using the CALIB radiocarbon calibration program, version 5.0.1 (after Stuiver and Reimer, 1993) in conjunction with a recent decadal atmospheric ${ }^{14} \mathrm{C}$ database (Reimer and others, 2004). We chose the option of two-sigma confidence for the analytical uncertainty of the calibrated ages.

The whole-rock geochemical database originates from a compilation undertaken by Kevin Johnson while at the Bishop Museum (in Honolulu) in the mid-1990s. We have built upon Johnson's database to incorporate analyses published since 1996 and some previously unpublished data that have been made available to us. No attempt was made to assess geochemical data quality or reliability except by verifying from the original published accounts.

Nearly 90 percent of the dated samples and 70 percent of geochemical analyses in the database have geographic coordinates assigned by us from written sample descriptions or sample location maps that accompanied many publications. This step was necessary to verify stratigraphic setting but also to grasp the sporadic spatial distribution of samples collected over the years. Through written correspondence, nearly 40 percent of the locations have been rechecked by the numerous scientists who made the original field collections, heightening the accuracy and precision of the geospatial data. Hidden in the convenience of this geochemical database is a huge blessing of aloha to those contributors for a debt we can never fully repay.

\section{About Spelling}

Spelling of Hawaiian words follows the usage in the Hawaiian Dictionary (Pukui and Elbert, 1986). Geographic place names are written as found in the Atlas of Hawai 'i (Juvik and others, 1998) and the online Geographic Names Information System managed by the U.S. Geological Survey (https://geonames.usgs. gov), as of 2018. We use a Hawaiian glottal stop, or 'okina, when writing State of Hawai'i, in keeping with the University of Hawai'i’s style guide. (Hawaiian is a fully anglicized word and requires no diacritical marks.)

We favor the parsimonious use of capital letters or "down" style advocated by the Chicago Manual of Style (University of Chicago Press, 2003) when referring to informally named features such as the major volcanoes along the island chain (for example, Ko'olau volcano, lowercase v). Kīlauea Volcano is officially rec-ognized by the U.S. Board on Geographic Names; therefore both its given name and generic term are capitalized. Most of the strati-graphic names applied to rock units have been formalized by past workers, but a few retain informal status. The use of uppercase and lowercase typography aids in making that distinction, too.

Titles in the "References Cited" section are written as found in the original publications. The Earth sciences literature is slowly accepting modern Hawaiian orthography. Thus, titles published before 1996 typically lack any diacritical marks; the 'okina occurs sporadically after 1996; and the Hawaiian macron, the kahakō, has crept into Earth science publications since 1999.

A final note on spelling may be helpful to users who avail themselves of the electronic databases that support this map. No diacritical marks are used in the geology-oriented part of the database, owing to the lack of conformity among the differing computer software for interpreting uncommon character encodings. Diacritical marks pose problems for GIS users who wish to search for text strings of stratigraphic names. In contrast, diacritical marks are retained in the spellings for the many geographic names in electronic files for base-map construction, because they appear on the map sheets.

\section{Island Growth in Review}

An island's growth and demise along the HawaiianEmperor chain is a history of volcanism, extinction, and erosion. Geologic mapping investigations led to a synoptic model in which the volcanoes grow through several volcanic stages, defined chiefly on the basis of gross lithologic, petrographic, and geomorphic changes (for example, Stearns, 1946). Subsequent advances in submarine geology and geophysics, the advent of radiometric dating, and ready availability of multi-element geochemical analyses have substantiated many aspects of these growth stages, including the timing of events. 


\section{Volcanic Evolution}

Popular today is an idealized model of Hawaiian volcano evolution that involves four eruptive stages: preshield, shield, postshield, and rejuvenated stages (Clague, 1987b; Clague and Dalrymple, 1987; Peterson and Moore, 1987). These stages likely reflect variation in the amount and rate of heat supplied to the lithosphere as the Pacific plate overrides the Hawaiian hot spot (Moore and others, 1982; Wolfe and Morris, 1996a). Volcanic extinction follows as a volcano moves away from the hot spot. Dissection by large landslides may occur any time in the growth or quiescence of a volcano, and subaerial erosion is ongoing whenever the volcano is emergent.

The geologic map units or groups of units on this map typically correspond closely to idealized stages of a volcano's growth-hardly surprising since the interpretive stages are rooted in geologic mapping. An illustrative example is West Maui volcano (Stearns and Macdonald, 1942). There, the Wailuku Basalt consists of tholeiitic basalt of the shield stage. Preshield lava, if present, is buried deeply in the core of the volcano. Analyses from the Wailuku Basalt indicate a spotty transition to more alkalic lava toward the end of shield growth. Overlying the Wailuku is the Honolua Volcanics, a postshield-stage sequence that contains distinctly more fractionated alkalic lava flows of benmoreite and trachyte; rocks of tholeiitic composition are lacking. Rejuvenated-stage volcanic rocks, the Lahaina Volcanics, are represented by four cinder and spatter cones and associated basanitic lava flows found on the west, southwest, and southeast sides of the West Maui volcano. The map units are based on field criteria, however, and not the interpretation of a volcanic episode. The assignment of growth-stage characteristics is an interpretation imposed after a geologic map is completed.

The transition from shield- to postshield-stage volcanism may be abbreviated or may not occur at all. In the abbreviated case, some of the stratigraphic units characteristic of shieldstage episodes may include, in their upper part, alkalic basalt interbedded among the tholeiitic lava flows. In the case of Kaua' $i$, sporadically distributed flows of even more evolved lava such as hawaiite or mugearite are found at the top of the shield-stage Nāpali Member or caldera-filling Olokele Member, both of the Waimea Canyon Basalt. No separate formation corresponding to these lava flows was mapped because of limited exposure or insufficient time available for mapping (Macdonald and others, 1960). Similarly, Kohala volcano (Island of Hawai'i) has sparse hawaiite and mugearite among the strata of the Pololū Volcanics, the stratigraphic formation that characterizes the shield stage there. Examples in which a volcano possesses no transitional or postshield lava are limited to Ko'olau and Lāna'i volcanoes (see Clague and Dalrymple, 1987), as well as the still-robust shieldstage volcanoes Mauna Loa and Kîlauea that may someday exult in the final stages of volcanic evolution.

The peppering of alkalic basalt lava flows in the upper part of some shield-stage sequences leads to a petrologic interpretation that the shield-to-postshield transition at some volcanoes begins before the onset of readily mapped postshield stratigraphic units (Macdonald, 1968; Sinton, 2005; Sinton and others, 2017). Consider a chemical variation diagram showing total alkalis versus silica (fig. 2), in which we create a composite picture showing the key volcanic stages from several well-known stratigraphic sequences. Few would argue against the shield-stage assignment for wholly tholeiitic lava from Kîlauea or Mauna Loa; nor is there quarrel that the benmoreite and trachyte of West Maui's Honolua Volcanics or the hawaiite and mugearite of Wai'anae's Pālehua Member of the Wai'anae Volcanics are postshield. But compositions annotated as stratigraphically transitional basalt on figure 2 , in this case from the Honomanu Basalt of Haleakalā and the Hāmākua Volcanics of Mauna Kea, lead to varying interpretation. The Hāmākua, the lowest stratigraphic sequence exposed at Mauna Kea, was considered shield-stage volcanism by Stearns and Macdonald (1946) but was redefined as a basaltic substage of postshield volcanism by Wolfe and others (1997). Are shield-stage strata exposed at Mauna Kea? The answer hinges on the interpretation of the geochemical data, a story we revisit in our discussion of Mauna Kea's history.

\section{Structure}

Geologic structures such as faults and folds are sparse on the geologic map (sheets 1-5). Except for caldera-bounding structures, few faults are mapped among the older volcanoes of the Hawaiian Islands. Kaua' $i$ is notable as the one older volcano with substantial structural complexity at the present level of subaerial exposure. This general lack of subaerial structure along the island chain is surprising, inasmuch as seismicity and active faulting are rampant during the shield-building stage, as determined from the historical record of the active volcanoes Kîlauea and Mauna Loa. Kîlauea, with its Hilina and Koa'e fault systems, has the best-developed subaerial fault system in the islands, at least for exposed offset. Presumably many of the structural zones are lost from view owing to large submarine landslides and slumps. What scarps might remain probably become mantled by later shield lava flows or, less commonly, by postshield lava.

\section{Nonvolcanic Deposits}

Erosion at volcanoes is constantly taking place, but its subaerial depositional products are mostly unremarkable during the shield and postshield stages of volcanism. Stream courses have moderate to high topographic gradients, so alluvium is transported to the sea, and only trifling amounts are left sandwiched thinly between lava flows. Some detritus is captured in structural traps such as calderas and graben, but typically these depressions are inundated and filled quickly by lava flows. Thus, little sediment is stored on the volcano, and that found is difficult to show at most map scales. As volcanism wanes, however, the balance is tipped toward more extensive alluvial deposits. Canyon floors of the windward drainages broaden and hold the sand and silt of meander belts (unit Qa). Large alluvial fans, shown as older alluvium (unit Qao) on the geologic map, mantle valley walls and some floors. In a few cases, younger lava flows have draped part of the older alluvium; examples are found on West and East Maui. On Kaua'i, some older alluvium is mapped as the Palikea Breccia Member of the Kōloa Volcanics. On O'ahu, similar beds are included locally in the Kolekole Member of the Wai'anae Volcanics. 


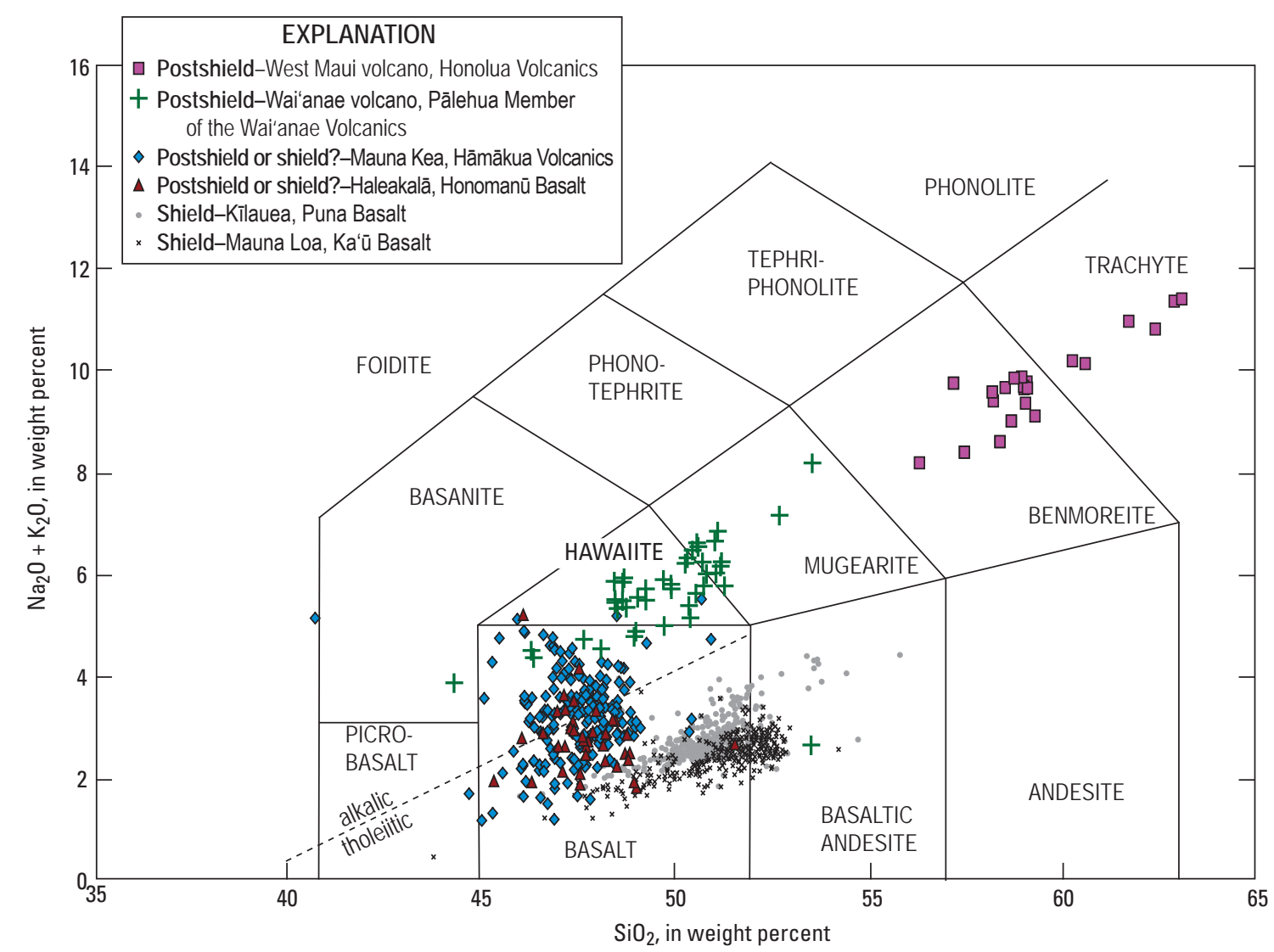

Figure 2. Alkali-silica diagram $\left(\mathrm{Na}_{2} \mathrm{O}+\mathrm{K}_{2} \mathrm{O}\right.$ versus $\left.\mathrm{SiO}_{2}\right)$ composited from several volcanoes. Rock classification grid labeled from Le Bas and others (1986), with tephrite-basanite field shown specifically as the olivine-bearing occurrence, basanite, as found commonly in Hawai'i. Dashed line shows boundary separating tholeiitic and alkalic basalt (Macdonald and Katsura, 1964). Data for Kīlauea and Mauna Loa on this and subsequent alkali-silica diagrams from Wolfe and Morris (1996b). Data sources for the other volcanoes are listed in captions for figures $11,23,25$, and 32.

Sedimentation also occurs at all volcanoes by the wind-driven redistribution of beach sand inland, where it forms dune deposits. Substantial calcareous dunes, however, develop only at volcanoes that have ended their shield- and postshield-stage volcanism, when rapid island subsidence ceases. In interpretations prior to 1980, these deposits were thought to have formed during Pleistocene low sea-level stands, when broad sand-covered flats might have been intermittently emergent and subject to ablation. Most modern workers disagree and instead favor formation during interglacial high stands of the sea (for example, Fletcher and others, 1999; Blay and Longman, 2001). Subsequent diagenetic cementation and recrystallization lithifies the deposits into eolianite.

Episodic deposition has created some features specific to a particular volcano. For example, glaciation of Mauna Kea has crowned it with moraines and outwash, deposits unique along the island chain. A large debris-flow sequence, the Kaupō Mud Flow on Haleakalā's south slope, probably stands alone among the archipelago's subaerial exposures by virtue of its preserved extent, thickness, and coarse, poorly sorted aspect. Smaller landslide deposits are mapped sporadically; the most extensive of these is the A.D. 1868 Wood Valley landslide on the southeast side of Mauna Loa. Landslides happen frequently, but most are small enough that their deposits are reworked downslope relatively quickly and lost from the geologic record. So, too, for the onshore deposits of conventional tsunami, which invariably are far too thin to show on most geologic maps.

\section{Megatsunami Deposits}

Disagreement still surrounds the origin for poorly sorted, coralline-bearing breccia found at widely ranging altitudes on the leeward sides of Kohala, West Maui, Lāna'i, and East Moloka'i volcanoes. These deposits are shown on our map as calcareous breccia and conglomerate (unit Qcbc) where sufficiently extensive to map separately. Many smaller sites are compiled as a separate layer in the GIS database. Although Stearns (1978) generally attributed these deposits to glacioeustatic marine high sea-level stands, substantial uplift of Lāna' $i$ and Moloka' $i$ is required to explain the deposits at these altitudes by this mechanism.

A hypothesis that has gained a wide level of acceptance explains these deposits as the consequence of catastrophic, giant waves (megatsunami) generated by several prehistoric large submarine landslides (J.G. Moore and Moore, 1984; G.W. Moore and Moore, 1988). The interpretation stems partly from the landward fining of the Lāna'i deposits (Moore and Moore, 1984) and landward fining in the carbonate-clast component of 
the Moloka'i deposits (A.L. Moore, 2000). The Lāna'i deposits were specifically attributed to the 'Ālika 2 Slide on the west side of Hawai' $i$ Island (Moore and others, 1989). The 'Ālika 2 was emplaced about $125 \mathrm{ka}$ on the basis of several lines of analysis (McMurtry and others, 1999).

The outstanding challenges to a giant-wave origin are threefold. One geochronologic study found a moderately high level of internal stratigraphic order for coral clasts within some of the deposits, on the basis of radiometric ages of the fragments (Rubin and others, 2000), results not in accord with chaotic deposition during a single megatsunami event. Some detailed sedimentologic analyses describe the Lāna' $i$ deposits as not exclusively tsunamigenic in origin (Felton and others, 2000). And interpretations that wave-cut notches are exposed above sea level on Moloka'i and Lāna' $i$ and that terraces lie at several altitudes on Moloka' $i$ (Grigg and Jones, 1997) call into question the amount of uplift that Lāna' $i$ and Moloka'i might have experienced in the past several hundred thousand years.

Recent estimates for uplift of O‘ahu suggest rates of 0.020$0.024 \mathrm{~m}$ per $1,000 \mathrm{yr}$ for the past 400,000 yr (Hearty, 2002). The result has been to expose calcareous reef rock and marine sediment (unit Qcrs), which is found only on O'ahu. The lack of these emerged reefs and lagoonal limestone beds elsewhere along the island chain suggests that uplift is the exception, not the rule. Although rates are less precisely defined for Lāna'i, during the past 30,000 yr that island has been relatively stable, with uplift or subsidence bracketed between +0.1 and $-0.4 \mathrm{~m}$ per $1,000 \mathrm{yr}$, on the basis of a sedimentary facies model for carbonate deposits on submerged terraces adjacent to the island (Webster and others, 2006). Clearly, a better understanding of vertical motions of all the Hawaiian Islands remains an important area of future research.

Compelling evidence in favor of the giant-wave hypothesis comes from deposits on Kohala volcano, Island of Hawai'i, where the question of uplift is made moot by the ongoing subsidence that has characterized Hawai'i Island since its emergence. The calcareous breccia of Kohala, found today at altitudes ranging from sea level to $100 \mathrm{~m}$, must have been deposited originally at altitude 350 to $390 \mathrm{~m}$ higher if corrected for modern rates of subsidence and reported age of the deposits (McMurtry and others, 2004).

\section{Summary of Island Geology}

We describe in the following sections the salient geologic features of each island, with an emphasis on new stratigraphic findings (for most islands as of 2007 and 2017 for West Moloka ${ }^{i}$ ) and unresolved problems of research in the past two decades. Numerous stratigraphic and lithologic details, omitted here, are available in most cases from the original reports that led to the sources of mapping used here. Readers should seek out those sources, both for the authoritative descriptions therein but also for an illuminating historical view of Hawai'i and ocean-island science during the 1930s, '40s, and '50s. We also highly recommend the island-byisland descriptions presented as the story of Hawai'i’s geology by Gordon Macdonald and colleagues, a book which through its first two editions has provided the fundamental introduction and reference work for generations of laypeople and scientists alike (Macdonald and others, 1983). Throughout our research we referred frequently to the stratigraphic summary of Langenheim and Clague (1987) and the geochronology summary by Clague and Dalrymple (1987, their appendix 1.1) for statewide topics reported here. Our discussion for volcanic stratigraphy on the Island of Hawai' $i$ is shortened relative to the other islands because past summaries by Moore and Clague (1992) and Wolfe and Morris (1996a) cover so much of the ground in exemplary style.

Herein we shy away from much discussion of the petrologic details of each volcano. Those studies have created an immense body of work, owing in part to the importance of the Hawaiian Islands in understanding basaltic volcanism worldwide. To present them fairly and comprehensively would double or triple the scope of our undertaking. Another harsh decision was the limited presentation of the submarine geology of the island chain, except as needed to better explain some of the subaerially exposed features.

\section{Ni'ihau}

\section{Setting and Stratigraphic Notes}

$\mathrm{Ni}$ 'ihau, covering $187 \mathrm{~km}^{2}$, is third smallest of the major Hawaiian Islands, larger only than Kaho'olawe and Lāna'i. Its land is held privately, and access is controlled; consequently it is one of the least visited and least studied of the Hawaiian Islands. Our geologic knowledge of the island's surface is limited almost entirely to the seminal study by Stearns (1947) and investigations in the 1970s by David A. Clague, G. Brent Dalrymple, and Richard R. Doell (for example, Doell, 1972).

$\mathrm{Ni}$ 'ihau is the eroded remnant of a single shield volcano (sheet 1; fig. 3). Topographically it consists of a central highland built almost entirely of shield-stage pāhoehoe lava flows (Pānī'au Basalt). A late vent, Kā'eo, stands about $60 \mathrm{~m}$ above the surrounding surface. Possibly a product of postshield-stage activity (Langenheim and Clague, 1987), Kā'eo is eroded to show mostly intrusive basalt. A surrounding coastal platform is underlain by lava flows (Ki'eki'e Basalt) assigned to rejuvenatedstage volcanism. More than 23 percent of this platform's area is mantled by alluvium and dune deposits. Offshore, a fringing wave-cut shelf extends out 5-10 km, beyond which the slopes plunge steeply to abyssal depth (fig. 3).

Radiometric ages were described only summarily by Langenheim and Clague (1987). The complete set of radiometric data, kindly provided by G. Brent Dalrymple (written commun., 2004), is presented here as table 1. Shield-stage lava, mapped as the Pānī'au Basalt, ranges in age from about 6.3 to $4.3 \mathrm{Ma}$ (table 1; fig. 4), a span of time similar to that represented by the exposed shield-stage lava flows of nearby Kaua' $i$ Island. The only available paleomagnetic data indicate that at least some of the dated lava flows possess reversed-polarity magnetization, and no normal-polarity findings were reported (Doell, 1972). As known today, the paleomagnetic time scale has a reversed-polarity epoch occurring from 4.799 to 4.631 Ma (Ogg and Smith, 2004), possibly the chief emplacement age of the exposed lava flows. Only about $400 \mathrm{~m}$ of shield-stage strata are found in the island's eastern sea cliffs. A duration as lengthy as 3 million years (m.y.) is allowed by the radiometric ages at 68 percent analytical 


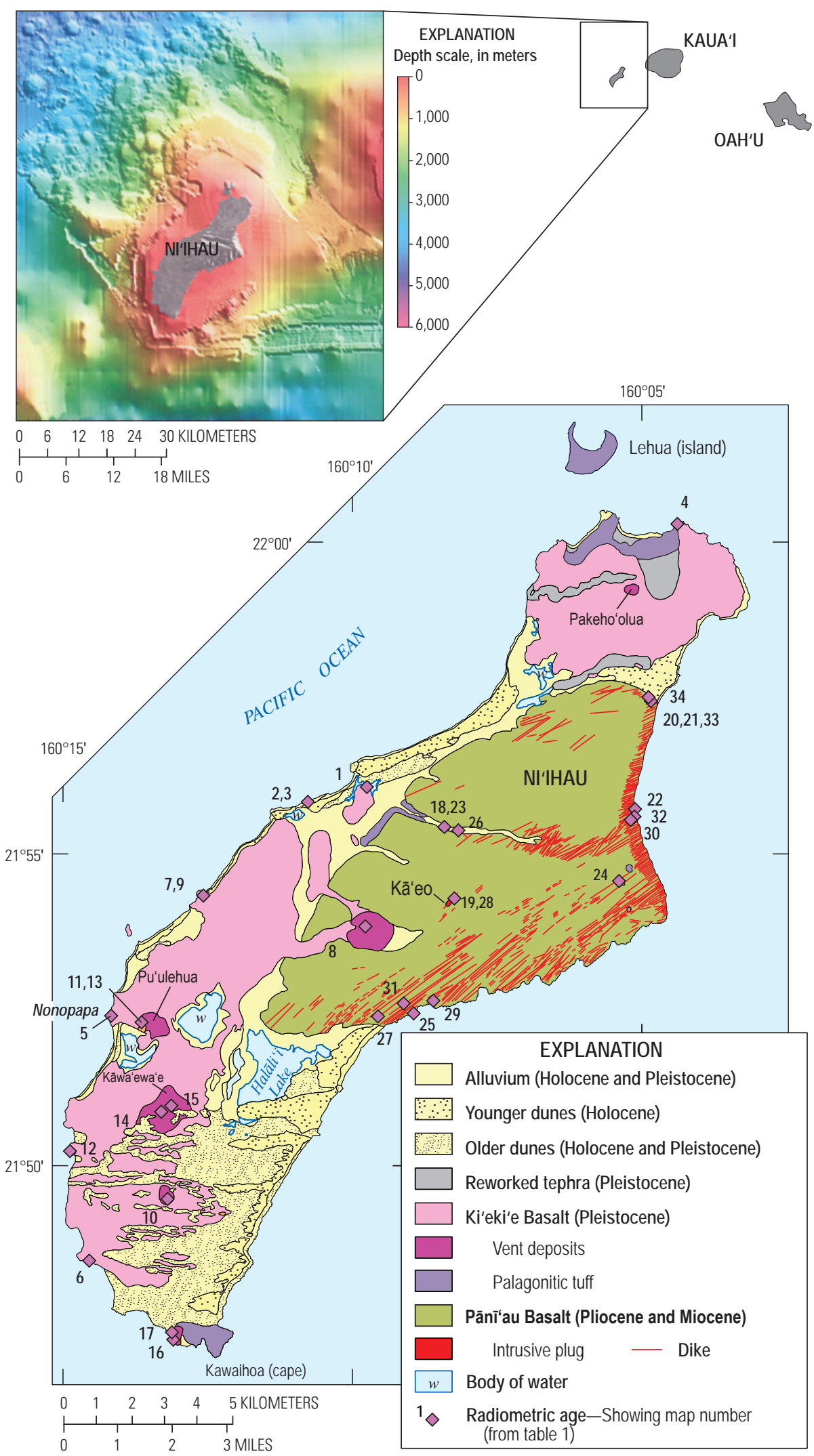

Figure 3. Geologic map of Ni'ihau, generalized from this publication's digital map database. Geology from Stearns (1947). Radiometric ages in table 1. Bathymetric map (at top) from Eakins and others (2003). 
confidence, but the actual span likely is less than 1 m.y. on the basis of accumulation rates known for other late-shield sequences along the island chain (Sharp and others, 1996; Guillou and others, 2000; Sherrod and others, 2007a).

Published chemical analyses for $\mathrm{Ni}$ ' ihau are sparse, so we rely heavily on unpublished data provided by D.A. Clague (written commun., 2004). The Pānī'au Basalt is almost entirely tholeiitic basalt, with the exception of a transitional basalt plug at Kā'eo, which straddles the boundary between tholeiitic and alkalic basalt (fig. 5). Langenheim and Clague (1987) described this lava as belonging to a postshield stage of volcanism but retained it within the Pānī'au Basalt. Two samples from that plug yielded ages of $5.15 \pm 0.11 \mathrm{Ma}$ and $4.67 \pm 0.08 \mathrm{Ma}$ (table 1), indistinguishable from ages obtained elsewhere in the Pānī'au Basalt.

$\mathrm{Ni}$ 'ihau's rejuvenated-stage lava ranges in age from about 2.32 to $0.35 \mathrm{Ma}$, with most of the lava flows younger than $1 \mathrm{Ma}$ (fig. 4). These lava flows and associated vent deposits form the $\mathrm{Ki}^{\prime}{ }^{\circ} \mathrm{ki}^{6} \mathrm{e}$ Basalt. They are chiefly alkalic basalt with lesser amounts of tholeiitic basalt (fig. 5). Reversed-polarity Ki'eki'e lava was sampled at the southern tip of the island (Doell, 1972), from the site that yielded K-Ar ages of $2.68 \mathrm{Ma}$ and $2.32 \mathrm{Ma}$ (table 1). The combination of the paleomagnetic polarity and radiometric age data suggest that the southern site is younger than $2.60 \mathrm{Ma}$.
Normal-polarity magnetization characterizes most other sampled $\mathrm{Ki}^{\prime}$ eki'e lava flows. Those sites are entirely within lava-flow units whose radiometric ages are younger than $0.78 \mathrm{Ma}$, in agreement with their emplacement during the Brunhes Normal-Polarity Chron.

Lehua island is a tiny $\mathrm{Ki}^{6}$ eki'e Basalt tuff cone, only $1.1 \mathrm{~km}^{2}$ in area, that lies $1 \mathrm{~km}$ north of $\mathrm{Ni}^{\prime}$ 'ihau (fig. 3). Undated, it is fairly youthful, to judge from its landform. Ash from its eruptions carried across much of $\mathrm{Ni}$ ' ihau and formed weakly consolidated dunes on the northern part of the island. These deposits are 1-5 m thick where mapped on Pakeho'olua ${ }^{1}$ cone, a small Ki'eki'e shield vent emplaced about 0.52 Ma that now forms the northern quarter of Ni'ihau. Stearns (1947) thought that Pakeho'olua was the youngest subaerial feature on $\mathrm{Ni}$ 'ihau itself (nearby Lehua island would be even younger.) Ages slightly younger than the 0.52-Ma Pakeho'olua age were obtained by G.B. Dalrymple (table 1) for some lava flows farther south along the west shore, but the stratigraphic relation of those units to Pakeho'olua and Lehua island cone is unknown.

\footnotetext{
${ }^{1}$ The geographic term "Pakeho'olua" was used by Stearns (1947) in his text but does not appear on the 1926 topographic base map or subsequent maps of $\mathrm{Ni}$ ' $i h a u$. The term is absent from modern geographic lexicons.
}

Table 1. Potassium-argon ages for Pānī'au and Ki'eki'e Basalts, Island of Ni'ihau, Hawai'i.

[Data courtesy of G. Brent Dalrymple. Geographic coordinates for sample locations in GIS data that accompany the digital version of this map on the Web at https://doi.org/10.3133/sim3143. See figure 3 for locations of samples. wt. \%, weight percent; g, grams; mol/g, mole per gram; Ma, mega-annum]

\begin{tabular}{|c|c|c|c|c|c|c|c|c|}
\hline $\begin{array}{c}\text { Map } \\
\text { No. }\end{array}$ & Sample No. & $\begin{array}{c}\mathrm{K}_{2} \mathrm{O} \\
\text { (wt. \%) }\end{array}$ & $\begin{array}{c} \pm S . D . \\
\text { (for } n>2)\end{array}$ & $\begin{array}{l}\text { Weight } \\
\text { (g) }\end{array}$ & $\begin{array}{c}{ }^{40} \mathrm{Ar}_{\mathrm{rad}}^{\dagger} \\
\left(10^{-12} \mathrm{~mol} / \mathrm{g}\right)\end{array}$ & $\begin{array}{l}{ }^{40} \mathrm{Ar}_{\text {rad }} \\
\text { (percent) }\end{array}$ & $\begin{array}{l}\text { Age } \pm 1 \sigma \text { error }^{\S} \\
(\mathrm{Ma})\end{array}$ & Rock type \\
\hline \multicolumn{9}{|c|}{ Ki'eki'e Basalt } \\
\hline 1 & 69 NII-8 & 0.326 & \pm 0.002 & 26.450 & 0.1650 & 4.9 & $0.35 \pm 0.07$ & \\
\hline 2 & 69NII-7 & 0.288 & \pm 0.007 (7) & 19.989 & 0.1677 & 4.1 & $0.40 \pm 0.14$ & Alkalic lava flow \\
\hline 3 & 69 NII-7 & 0.311 & \pm 0.003 & 28.420 & 0.2114 & 7.6 & $0.47 \pm 0.06$ & \\
\hline \multirow[t]{2}{*}{4} & $70 X 121$ & 0.248 & \pm 0.005 (8) & 17.905 & 0.1983 & 3.2 & $0.52 \pm 0.20$ & \\
\hline & & & & 17.943 & 0.1490 & 1.7 & & \\
\hline 5 & 69 NII-4 & 0.243 & \pm 0.005 (6) & 15.645 & 0.2137 & 2.1 & $0.61 \pm 0.32$ & Alkalic lava flow \\
\hline \multirow[t]{2}{*}{6} & 70NII-7 & 0.295 & \pm 0.003 & 20.091 & 0.2540 & 7.3 & $0.63 \pm 0.15$ & Alkalic lava flow \\
\hline & & & & 20.047 & 0.3805 & 4.1 & & \\
\hline 7 & 69NII-3 & 0.208 & \pm 0.003 & 23.983 & 0.1911 & 3.5 & $0.64 \pm 0.18$ & Alkalic lava flow \\
\hline \multirow[t]{2}{*}{8} & 70NII-18 & 0.453 & \pm 0.007 (8) & 16.939 & 0.3697 & 5.8 & $0.66 \pm 0.07$ & Alkalic lava flow \\
\hline & & & & 17.102 & 0.5163 & 8.1 & & \\
\hline 9 & 69 NII-3 & 0.222 & $\pm 0.011(8)$ & 19.982 & 0.2156 & 3.4 & $0.67 \pm 0.20$ & \\
\hline \multirow[t]{2}{*}{10} & 75NII-13 & 0.486 & \pm 0.004 (4) & 24.889 & 0.553 & 16.5 & $0.69 \pm 0.03$ & Alkalic lava flow, Mau'uloa \\
\hline & & & & 25.125 & 0.404 & 12.4 & & \\
\hline 11 & 69NII-6 & 0.310 & \pm 0.003 (4) & 25.607 & 0.3444 & 3.3 & $0.77 \pm 0.23$ & Alkalic lava flow \\
\hline \multirow[t]{2}{*}{12} & 70NII-11 & 0.291 & \pm 0.004 (7) & 19.965 & 0.4082 & 5.4 & $1.05 \pm 0.10$ & Alkalic lava flow \\
\hline & & & & 19.761 & 0.4617 & 7.6 & & \\
\hline 13 & 69NII-6 & 0.274 & \pm 0.002 & 19.975 & 0.5465 & 5.3 & $1.38 \pm 0.25$ & \\
\hline \multirow[t]{2}{*}{14} & 70NII-21 & 0.376 & \pm 0.004 (4) & 18.877 & 1.0730 & 18.0 & $2.03 \pm 0.07$ & Alkalic lava flow, Kāwa'ewa'e \\
\hline & & & & 18.826 & 1.1370 & 18.5 & & \\
\hline \multirow[t]{2}{*}{15} & 75NII-14 & 0.304 & \pm 0.005 (4) & 25.272 & 0.937 & 21.9 & $2.28 \pm 0.05$ & Alkalic lava flow, Kāwa'ewa'e \\
\hline & & & & 25.406 & 1.048 & 33.8 & & \\
\hline
\end{tabular}


Table 1. Potassium-argon ages for Pānī'au and Ki'eki'e Basalts, Island of Ni'ihau, Hawai'i.—Continued

\begin{tabular}{|c|c|c|c|c|c|c|c|c|}
\hline $\begin{array}{l}\text { Map } \\
\text { No. }\end{array}$ & Sample No. & $\begin{array}{c}\mathrm{K}_{2} \mathrm{O} \\
\text { (wt. \%) }\end{array}$ & $\begin{array}{c} \pm S . D . \\
\text { (for } n>2 \text { ) }\end{array}$ & $\begin{array}{l}\text { Weight } \\
\text { (g) }\end{array}$ & $\begin{array}{c}{ }^{40} \mathrm{Ar}_{\mathrm{rad}}{ }^{\dagger} \\
\left(10^{-12} \mathrm{~mol} / \mathrm{g}\right)\end{array}$ & $\begin{array}{l}{ }^{40} \mathrm{Ar}_{\text {rad }} \\
\text { (percent) }\end{array}$ & $\begin{array}{c}\text { Age } \pm 1 \sigma \text { error }^{\S} \\
(\mathrm{Ma})\end{array}$ & Rock type \\
\hline \multicolumn{9}{|c|}{ Ki'eki'e Basalt-Continued } \\
\hline \multirow[t]{2}{*}{16} & 70NII-4 & 0.222 & \pm 0.001 & 18.748 & 0.8066 & 21.2 & $2.32 \pm 0.09$ & Alkalic lava flow \\
\hline & & & & 19.192 & 0.6971 & 18.5 & & \\
\hline \multirow[t]{4}{*}{17} & 75 NII-69 & 0.286 & \pm 0.006 (4) & 18.151 & 1.100 & 5.4 & $2.68 \pm 0.30$ & \\
\hline & & & & 23.438 & 1.061 & 5.0 & & \\
\hline & & & & 21.923 & $(1.350)$ & 5.7 & & \\
\hline & & & & 17.426 & 1.168 & 4.7 & & \\
\hline \multicolumn{9}{|c|}{ Pānī‘au Basalt } \\
\hline \multirow[t]{2}{*}{18} & 70NII-15 & 0.479 & \pm 0.005 (8) & 19.169 & 3.129 & 7.7 & $4.33 \pm 0.45$ & Tholeiitic lava flow(?) \\
\hline & & & & 19.387 & 2.837 & 6.7 & & \\
\hline \multirow[t]{4}{*}{19} & 75NII-1 & 0.636 & \pm 0.003 & 24.806 & 4.067 & 45.7 & $4.67 \pm 0.08$ & Alkalic lava flow, Kā‘eo \\
\hline & & & & 24.637 & (3.699) & 43.7 & & \\
\hline & & & & 25.508 & 4.436 & 49.9 & & \\
\hline & & & & 25.441 & 4.384 & 46.0 & & \\
\hline \multirow[t]{2}{*}{20} & $69 \times 019$ & 0.263 & \pm 0.005 (8) & 14.999 & 1.791 & 24.4 & $4.68 \pm 0.14$ & Tholeiitic lava flow \\
\hline & & & & 15.001 & 1.753 & 21.5 & & \\
\hline 21 & $69 \times 018$ & 0.264 & (2) & 26.384 & 1.811 & 24.9 & $4.76 \pm 0.14$ & Tholeiitic lava flow \\
\hline \multirow[t]{2}{*}{22} & 70NII-23 & 0.536 & \pm 0.003 (4) & 18.558 & 3.753 & 42.3 & $4.86 \pm 0.11$ & Alkalic dike \\
\hline & & & & 18.535 & 3.763 & 44.7 & & \\
\hline \multirow[t]{2}{*}{23} & 70NII-14 & 0.275 & \pm 0.007 (8) & 20.134 & 1.978 & 21.5 & $4.90 \pm 0.16$ & Tholeiitic lava dike \\
\hline & & & & 20.030 & 1.914 & 22.5 & & \\
\hline \multirow[t]{2}{*}{24} & 75NII-10 & 0.713 & \pm 0.005 (4) & 24.686 & 4.882 & 55.8 & $4.90 \pm 0.10$ & Alkalic dike \\
\hline & & & & 24.667 & 5.217 & 61.2 & & \\
\hline \multirow[t]{3}{*}{25} & 75 NII-61 & 0.281 & \pm 0.003 (4) & 24.731 & 1.999 & 14.4 & $4.98 \pm 0.28$ & Tholeiitic lava flow \\
\hline & & & & 24.662 & $(2.496)$ & 18.7 & & \\
\hline & & & & 10.624 & 2.061 & 9.8 & & \\
\hline \multirow[t]{2}{*}{26} & 70NII-17 & 0.536 & \pm 0.005 (8) & 19.004 & 3.866 & 45.5 & $5.05 \pm 0.23$ & Tholeiitic dike(?) \\
\hline & & & & 19.234 & 4.232 & 36.2 & & \\
\hline \multirow[t]{2}{*}{27} & $75 \mathrm{NII}-65$ & 0.340 & \pm 0.004 & 24.984 & 2.404 & 12.1 & $5.11 \pm 0.24$ & Tholeiitic lava flow \\
\hline & & & & 23.012 & 2.584 & 14.5 & & \\
\hline \multirow[t]{2}{*}{28} & 75NII-2 & 0.617 & \pm 0.002 & 23.827 & 4.803 & 60.6 & $5.15 \pm 0.11$ & Alkalic lava flow, $K \bar{a}$ ‘eo \\
\hline & & & & 23.852 & 4.386 & 59.5 & & \\
\hline \multirow[t]{2}{*}{29} & 75NII-57 & 0.327 & \pm 0.004 (4) & 24.619 & 2.550 & 22.7 & $5.38 \pm 0.13$ & Tholeiitic lava flow \\
\hline & & & & 24.344 & 2.528 & 23.0 & & \\
\hline \multirow[t]{2}{*}{30} & 70NII-24 & 0.193 & \pm 0.003 & 15.952 & 1.549 & 20.1 & $5.54 \pm 0.19$ & Tholeiitic dike \\
\hline & & & & 17.059 & 1.554 & 18.8 & & \\
\hline \multirow[t]{4}{*}{31} & $75 \mathrm{NII}-67$ & 0.314 & \pm 0.004 (4) & 19.893 & 2.279 & 10.9 & $5.56 \pm 0.24$ & Tholeiitic lava flow \\
\hline & & & & 20.616 & 2.418 & 12.9 & & \\
\hline & & & & 20.011 & 2.916 & 13.0 & & \\
\hline & & & & 14.893 & $(5.187)$ & 17.0 & & \\
\hline \multirow[t]{2}{*}{32} & 70NII-25 & 0.181 & \pm 0.015 (4) & 18.764 & 1.494 & 3.5 & $6.30 \pm 1.19$ & Tholeiitic lava flow \\
\hline & & & & 9.348 & 1.830 & 3.9 & & \\
\hline 33 & $69 \times 020$ & 0.299 & \pm 0.017 (4) & 22.961 & 1.161 & 16.4 & $(2.69 \pm 0.34)$ & Tholeiitic lava flow \\
\hline 34 & $69 \times 028$ & 0.367 & (2) & 20.953 & 1.550 & 14.0 & $(3.05 \pm 0.13)$ & Tholeiitic lava flow \\
\hline
\end{tabular}

${ }^{\dagger}$ Values shown parenthetically for ${ }^{40} \mathrm{Ar}_{\text {rad }}$ not used in final age calculation (G.B. Dalrymple, written commun.).

$\S$ Values shown parenthetically for age of samples 33 and 34 rejected for stratigraphic reasons (G.B. Dalrymple, written commun.). 


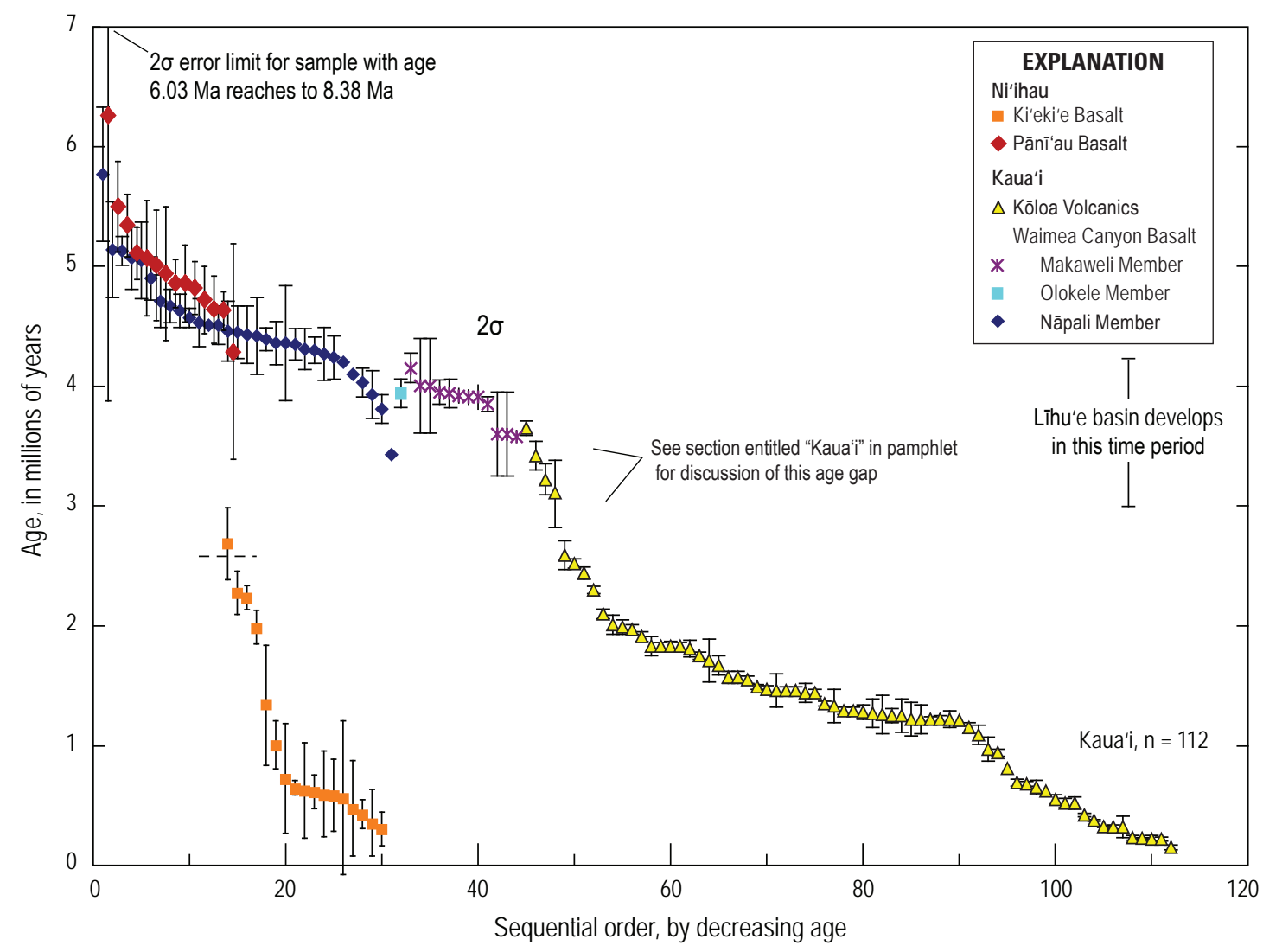

Figure 4. Radiometric ages for geologic units on Nithau and Kaua'i. Data for Nitihau courtesy of G.B. Dalrymple (table 1). For Kaua'i, one Nāpali Member age reported without analytical error (Evernden and others ,1964). Other ages from Evernden and others (1964), McDougall (1964, 1979), Clague and Dalrymple (1988), Hearty and others (2005), Garcia and others (2010), Clague and Sherrod (2014), and Sherrod and others (2015). Dashed line marks age of magnetic polarity-chron boundary, which restricts oldest Ki'eki'e sample to age younger than $2.58 \mathrm{Ma}$.

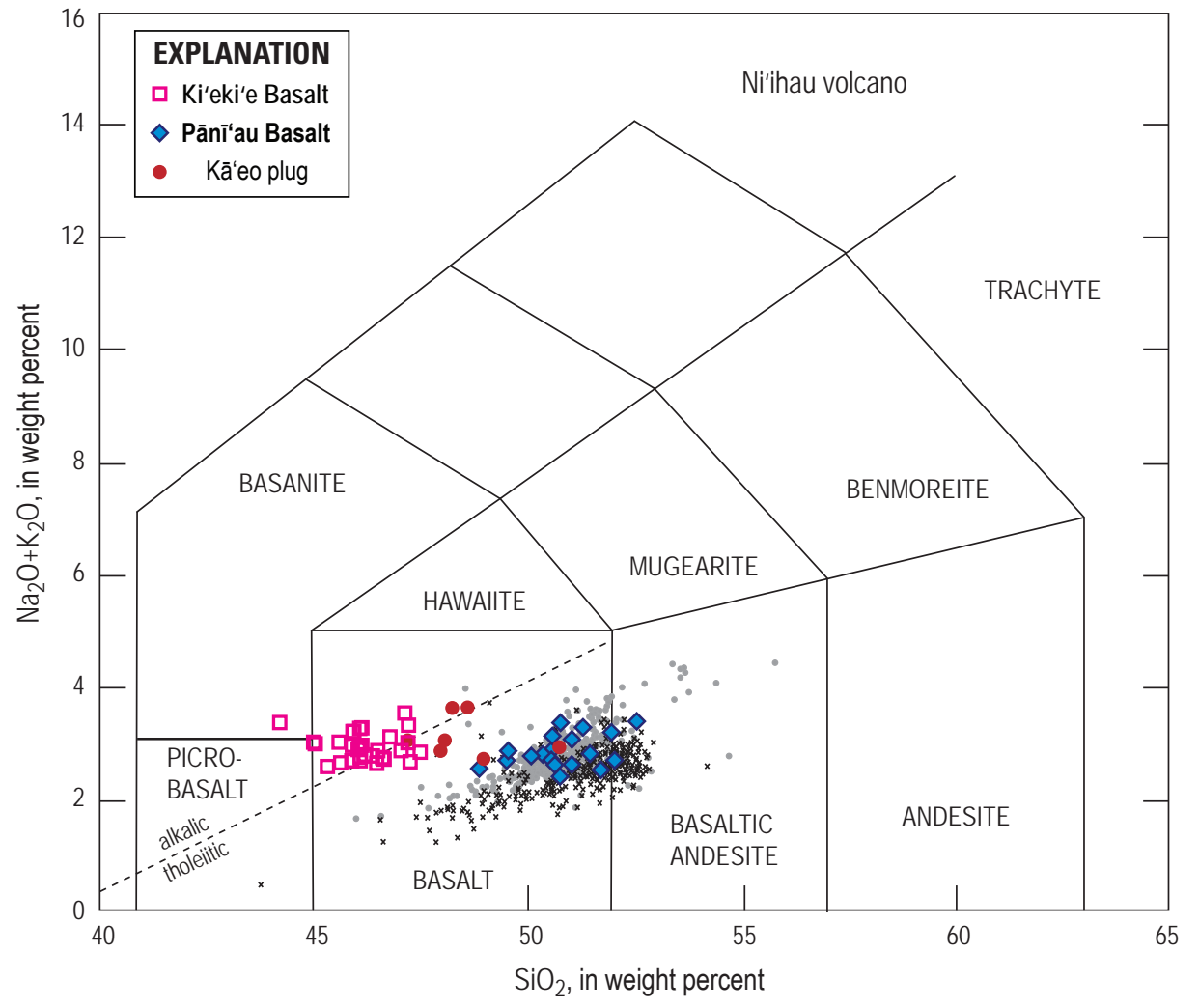

Figure 5. Alkali-silica $\left(\mathrm{Na}_{2} \mathrm{O}+\mathrm{K}_{2} \mathrm{O}\right.$ versus $\mathrm{SiO}_{2}$ ) diagram for analyzed rocks from Nitihau. Grid fields labeled for those compositional types commonly recognized in Hawaiian Islands; grid boundaries and Mauna LoaKïlauea data (small black $x$ and gray dot symbols) referenced in figure 2 caption. Nitihau chemical data from D.A. Clague (unpub. data, 50 analyses), Washington and Keyes (1926, 5 analyses), and Macdonald (1968, 1 analysis). 
Stearns (1947) described four shoreline features at 8 and $60 \mathrm{~m}$ altitude on cinder cones and lava flows of the $\mathrm{Ki}^{\text {'eki'e }}$ Basalt that may warrant reevaluation in light of megatsunami deposits found elsewhere along the island chain. On the southern part of the island, black mud, possibly of marine origin, fills the crater of Pu'ulehua cone, and a ledge of rock he thought had been swept bare by the sea crops out on the northwestern side of the cone at about $30 \mathrm{~m}$ altitude. A well-preserved shoreline was found farther south, at Kāwa'ewa'e cone, where fossiliferous limestone at about $8 \mathrm{~m}$ altitude can be traced around the cone's northwest slope. At the southern tip of the island, Stearns found a ledge of reef limestone perched at $30 \mathrm{~m}$ altitude on Kawaihoa cone. The Kāwa'ewa'e and Kawaihoa limestone occurrences are each shown by an $\times$ symbol on his map (Stearns, 1947), which suggests their extent was limited. (An $\times$ marks the spots on our rendition, too; sheet 1.) Deposits mapped and described in a similar manner on Lāna'i and Maui (Stearns, 1940c; Stearns and Macdonald, 1942) are thought by many modern researchers to be onshore evidence of megatsunami.

The fourth occurrence, on the northwest coast, was described as a "stack of coralline limestone about $12 \mathrm{ft}$ high" exposed where the road landward of Keawanui Bay crosses older dune deposits (unit Qdo) near Kahunalii Valley. This low-lying deposit ( $<5 \mathrm{~m}$ altitude) lies in a trough behind the shoreline dune crest.

\section{Kaua'i}

\section{Setting and Stratigraphic Notes}

Kaua' $i$, one of the older islands in the chain, is also the most complex structurally. Generally thought of as a singlevolcano island, some isotopic data challenge that interpretation. Consequently, Kaua'i provides many opportunities to substantially broaden our understanding of how ocean-island volcanoes develop.

Strata forming the main mass of the Kaua'i volcanic complex are assigned to the Waimea Canyon Basalt, a formation containing separate members that record the growth of the shield and the late structural development of a central caldera and adjacent graben (fig. 6). Radiometric ages indicate that the subaerial part of the Kaua'i volcanic complex grew mainly between 5.5 and $4 \mathrm{Ma}$ (fig. 4); these strata form the Nāpali Member of the Waimea Canyon Basalt. A caldera was probably present throughout much of Waimea time, and it ultimately expanded to encompass a roughly circular area 18-19 km across. The caldera-filling deposits, assigned to the Olokele Member, are chiefly thick lava flows that ponded within the caldera depression about $4 \mathrm{Ma}$, on the basis of a single radiometric age. Talus breccia accumulated near the caldera walls and is exposed locally along the present-day mapped boundary. Mapping of the caldera boundary was based on the finding of thick lava flows (of the Olokele Member) juxtaposed against thin lava flows (of the Nāpali Member) and, where exposures were suitable, the presence of colluvial breccia deposits preserved on the paleoslopes of the caldera walls (Macdonald and others, 1960).

The geologic map (sheet 1) shows the Kalalau fault, of highly irregular trace, north of the Olokele caldera. Macdonald and others (1960) thought this fault formed at about the same time and in same manner as the caldera-bounding fault. When viewed in detail on topographic base, it is seen to range from nearly vertical to nearly horizontal. Little is known in detail of the Kalalau fault, which may be a composite of features found in the cliffy exposures of northeast Kaua' $i$.

Eruptions filled the summit caldera, and lava spilled outward in some areas. Once free of the ponding effect of the caldera depression, these lava flows formed thin pāhoehoe and 'a'ā, similar to lava flows of the Nāpali Member. These spillover flows were necessarily included with the Nāpali Member, owing to their similar aspect and the limited amount of time available for the original mapping project (Macdonald and others, 1960). Thus the Nāpali is a time-transgressive stratigraphic unit whose upper part is coeval with the Olokele Member.

A more restrictive view of the Nāpali-Olokele relation was suggested by Bogue and Coe (1984) on the basis of paleomagnetic directions measured at four sites across the island. In their interpretation, the upper part of the Nāpali contains the reversed-polarity chronozone 3n.1.r and overlying normalpolarity chronozone 3n.1.n, the boundary of which is about 4.30 Ma (Ogg and Smith, 2004). The caldera-filling Olokele Member preserves another polarity reversal interpreted by Bogue and Coe (1984, their Kāhililoa site) as normal-polarity chronozone 3n.1.n overlain by reversed-polarity chronozone 2Ar. This latter polarity boundary formed about 4.187 Ma (Ogg and Smith, 2004). Applied broadly, this interpretation suggests that the Olokele caldera never overflowed extensively, because the capping reversed-polarity lava flows of the Olokele Member are lacking from the upper part of the Nāpali Member. In our view, the number of paleomagnetic sampling sites is too sparse, but the application of paleomagnetism for refining the stratigraphic understanding of Kaua'i remains tantalizing. Indeed, future detailed mapping may resolve chemical or magnetostratigraphic characteristics that permit finer delineation across the mapped breadth of the Nāpali and Olokele Members.

Late in Olokele time, a flanking structural trough, the Makaweli graben, developed southward from the Olokele caldera to become another site of lava deposition. Lava flows in the graben are assigned to the Makaweli Member of the Waimea Canyon Basalt. A volumetrically minor part of the Makaweli Member is the Mokuone Breccia Beds, which contains a few layers of conglomerate and breccia found at the base of the graben-filling sequence and interbedded in its lower part. Radiometric ages indicate that lava was emplaced in the Makaweli graben from about 4 to $3.5 \mathrm{Ma}$.

Another stratigraphic unit, the Hā'upu Member of the Waimea Canyon Basalt, was thought to have originated in a small caldera on the southeast flank of the Kaua'i volcanic complex, $20 \mathrm{~km}$ from the summit area. The Hā'upu Member contains nearly flat-lying, thick lava flows and coarse breccia described as sitting concordantly and discordantly on the underlying Nāpali Member (Macdonald and others, 1960). No faults are shown in the area on the original geologic map, but a small page-size figure showed the Hā'upu caldera as fault bounded (Macdonald and others, 1960, compare their plate 1 and their fig. 18). Doubtless the Hā'upu Member is a record of volcanic fill, but whether it is a separate caldera $4 \mathrm{~km}$ in diameter, the remnant of a valley wall, or the edge of the much larger Lìhu'e 

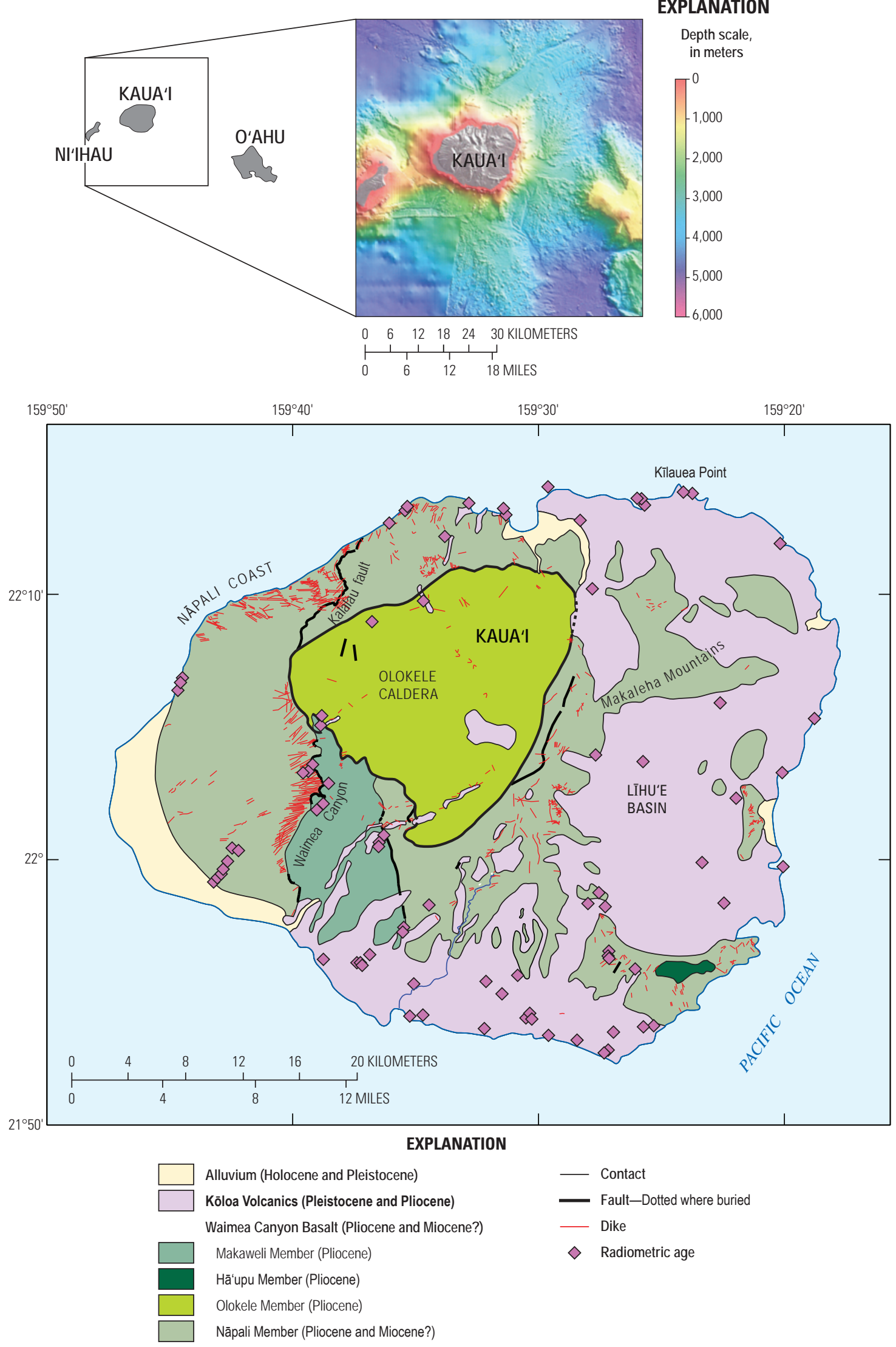

Figure 6. Geologic map of Kaua'i, generalized from this publication's digital map database. Geology from Macdonald and others (1960). Bathymetric map (at top) from Eakins and others (2003). 
basin (in the section "Lîhu'e Basin") seems open to speculation. The Hā'upu Member has radiometric ages in the range 4.4 to 4.3 Ma (Garcia and others, 2010).

Rift zones on Kaua'i are poorly developed, as indicated by the symmetrical form of the Kaua'i shield compared to the typical Hawaiian shield volcano. This distinction may result from Kaua'i’s distance from its nearest neighbor, $\mathrm{Ni}^{\prime}$ ihau, which allowed it to grow in a nearly symmetrical stress field (Fiske and Jackson, 1972). The shield-stage lava flows assigned to the Nāpali Member of the Waimea Canyon Basalt typically dip outward away from the main volcanic center defined by the island's summit area. Bouguer gravity contours (Krivoy and others, 1965) show an elongate gravity high that extends northwestward from a maximum in the Lìhu'e basin; these gravity contours are the basis for some depictions showing a rift zone in a northwest-southeast orientation (Fiske and Jackson, 1972). The density of gravity stations is sparse, however, and enhanced station coverage in the mountainous region southwest and west of the Linh'e basin could change the sense of elongation or weaken it greatly. An alternative interpretation of two rift zones oriented northeast and west-southwest arise from the geologic source map (Macdonald and others, 1960). The northeast trend is inferred from the gentle dip of lava flows in the Makaleha Mountains in the northeastern part of the island and a submarine bathymetric bulge off the northeast shore (fig. 6, bathymetric map). The west-southwest trend is inferred from the numerous dikes exposed in the west wall of Waimea Canyon (Macdonald and others, 1960; Macdonald and others, 1983).

Kaua'i geologic maps lack a stratigraphic unit that corresponds directly to the postshield volcanic stage found at several Hawaiian volcanoes. However, some lava flows in the compositional range hawaiite to mugearite, characteristic of postshield strata in other volcanoes, are scattered among the upper part of the Olokele and Makaweli Members and were encountered in drill holes that penetrate the Lìhu'e basin (Reiners and others, 1999) (fig. 7). The drill-hole analyses, obtained from bulk cuttings thought to represent lava flows in the Nāpali Member, are compositionally distinct from analyses of Nāpali basaltic rocks from outcrops (fig. 7).

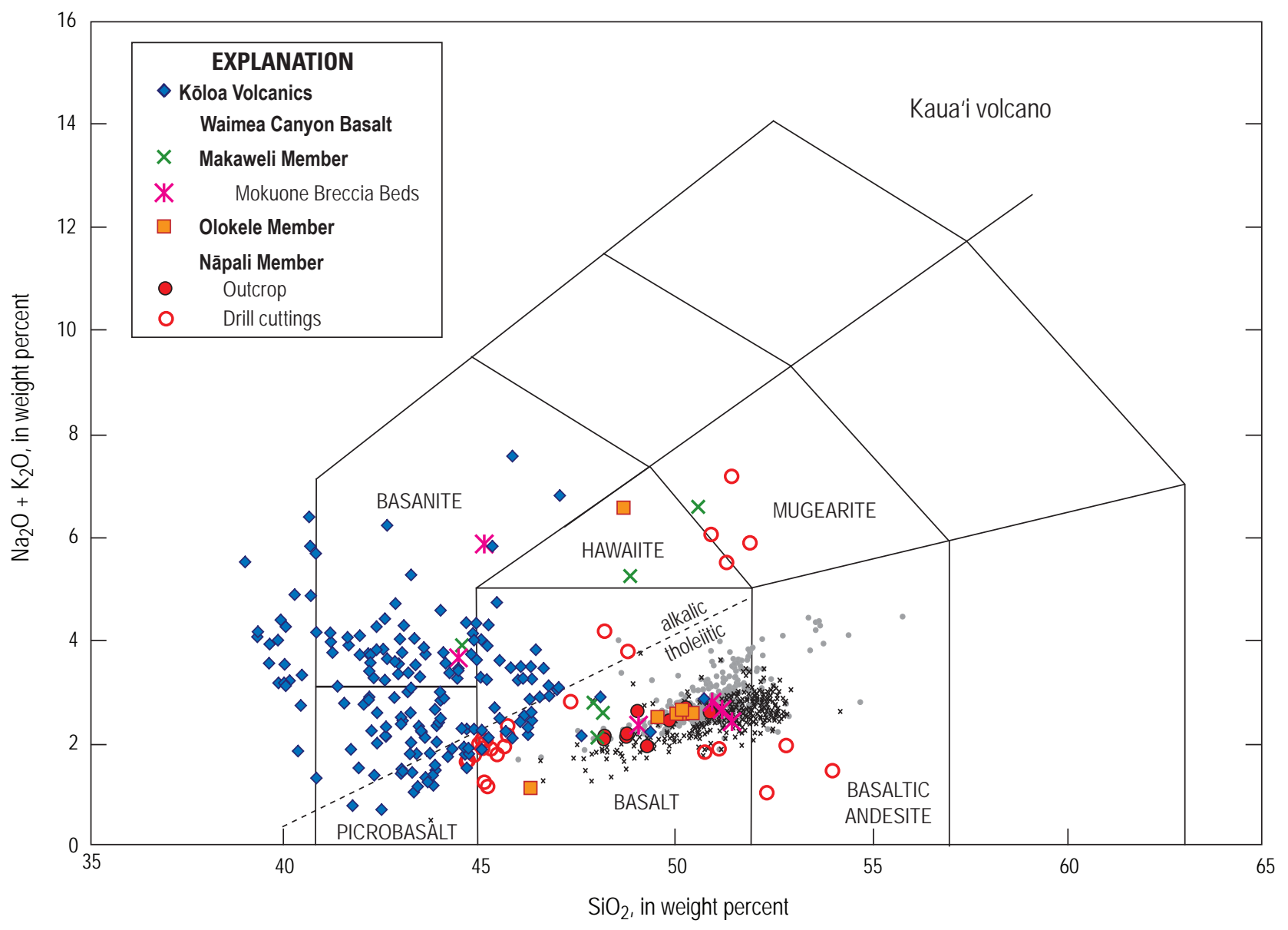

Figure 7. Alkali-silica $\left(\mathrm{Na}_{2} \mathrm{O}+\mathrm{K}_{2} \mathrm{O}\right.$ versus $\left.\mathrm{SiO}_{2}\right)$ diagram for analyzed rocks from Kaua'i. Grid boundaries and Mauna Loa-Kīlauea data (small black $x$ and gray dot symbols) referenced in figure 2 caption. Kaua'i chemical data from Clague and Dalrymple (1988, 55 analyses), Reiners and others (1999, 54 analyses), Reiners and Nelson (1998, 46 analyses), Palmiter (1975, 29 analyses), Washington and Keyes (1926, 1 analysis), Maaløe and others (1992, 18 analyses), Macdonald and others (1960, 14 analyses), Garcia (1993, 14 analyses), Macdonald and Katsura (1964, 12 analyses), Macdonald (1968, 11 analyses), Feigenson (1984, 11 analyses), Cross (1915, 3 analyses), and Kay and Gast (1973, 3 analyses). 
What Kaua'i may lack in readily mapped postshield strata seems more than compensated for by an extensive field of rejuvenated-stage volcanic rocks, the Kōloa Volcanics. The Kōloa includes all the lava flows and vent deposits lying largely in a post-erosional setting that were erupted long after the main stage of shield growth ended. The rejuvenated-stage lava flows, chiefly basanite, were emplaced mainly between 2.6 and $0.15 \mathrm{Ma}$ (Clague and Dalrymple, 1988; Garcia and others, 2010). A few ages reach back to $3.65 \mathrm{Ma}$ (Clague and Dalrymple, 1988), including three from drill cuttings in the Lihue basin (Sherrod and others, 2015), all of which have ${ }^{87} \mathrm{Sr} /{ }^{86} \mathrm{Sr}$ isotopic ratios characteristic of the Kōloa. The oldest age, $3.65 \pm 0.06 \mathrm{Ma}$, overlaps with ages from the underlying Makaweli Member (fig. 4, this report; Clague and Dalrymple, 1988). It provokes the longstanding debate between those who view "rejuvenated stage" as a geochemical distinction marked by the occurrence of undersaturated alkalic lava versus those who desire geologic or geochronologic evidence for a significant break in eruptive activity prior to rejuvenation.

\section{Līhu'e Basin}

The Lîhu'e basin is an elongate lowland on the east-central side of Kaua' $i$. It is fully drained by east-flowing streams mostly tributary to the Wailua River and Hanamā'ulu and Hulē'ia Streams. A north-trending ridge of shield-stage lava flows (Nāpali Member of Waimea Canyon Basalt) forms the east side of the basin, within which a pervasive veneer of Kōloa Volcanics is as thick as $225 \mathrm{~m}$ (Reiners and others, 1999). In the basin, fossiliferous marine mudstone was penetrated in drill holes at depths 125 to 175 m below modern sea level (Izuka and Gingerich, 1997a, b, c, d; Gingerich and Izuka, 1997a, b).

A structure-contour map (fig. 8) shows the altitude at the base of the Kōloa Volcanics within the basin; elsewhere the contours mark the altitude at the top of the Kaua'i shield. The structure map also elucidates a 30-km-long east-facing steep slope thought to have originated as the headwall escarpment for a major gravitydriven flank fault that ceased motion before the east side of the island dropped completely below sea level (fig. 8B, this report; Sherrod and others, 2015). The fault lacks expression on the north and south submarine flanks of Kaua' $i$, which is in agreement with its diminished offset away from the island's center. The Lîhu'e basin's west side is coincident with the headwall escarpment, but the basin itself lies wholly within the area of the large downdropped block (fig. 8C). The structure-contour map and adjacent bathymetric setting (fig. 8) lead us to favor a subsidence origin for the Lìhu'e basin. The hypotheses for erosional and calderacollapse origins for the basin were summarized by Macdonald and others (1960), who concluded that evidence was sparse but that a caldera-collapse origin might be favored because it was the simpler of the two choices considered by them. A landslide hypothesis was suggested by Reiners and others (1999) and us, in a preliminary version of this map (Sherrod and others, 2007b).

\section{Two Shields or One?}

As offered by Macdonald and others (1960), the depiction of Kaua' $\mathrm{i}$ as a single-shield volcano is the best-known interpretation of volcanic history for the island. An alternative interpretation has been suggested on the basis of strontium isotopic analyses from late-shield strata of the Waimea Canyon Basalt on the west and east sides of the island, which differ sufficiently to suggest that two magma-supply systems were erupting during the growth of Kaua'i (Holcomb and others, 1997). An additional rationale offered in support of a two-volcano hypothesis is the possibility of numerous rift zones radiating outward in as many as five directions (Holcomb and others, 1997). The suggestion that numerous weakly developed Kaua'i rift zones may coincide with small elongate submarine ridges was noted earlier by Clague (1990). Most Hawaiian volcanoes have three or fewer rift zones (see Fiske and Jackson, 1972); hence the inference that more than one volcano is present on an island with multiple rift zones. A twovolcano, five-zone rift system was depicted in a simplified map figure by Clague (1996), but no discussion ensued.

Another explanation for the Sr isotopic spatial pattern is that it results from sampling across disparate parts of a single volcano's stratigraphic sequence. Thus, the across-island isotopic variation could mark the volcanic expression of changing mantle source as the Pacific plate was transported over a radially or vertically zoned hot-spot plume, as suggested by Mukhopadhyay and others (2003) from their more detailed study of isotopic variations within Nāpali Member strata. A zoned plume was invoked by previous workers to explain contrasts within volcanoes like West Maui, Haleakalā, and Mauna Loa.

To diminish the effect of stratigraphic variation, Holcomb and others (1997) based their sampling on the position of a magnetostratigraphic polarity boundary thought correlative across Kaua'i, on the basis of similar paleomagnetic directions measured at sites on the west and east sides of the island (Bogue and Coe, 1984). This correlation has never been tested rigorously, however, insofar as no radiometric ages have been reported from the Waimea Canyon Basalt on the east half of the island. Most of the ages obtained from the Waimea Canyon Basalt span the time from about 5 to $4 \mathrm{Ma}$, a period when the Earth's magnetic polarity switched from reversed to normal and back no fewer than four times. Thus the sampled strata, if mismatched, may differ in age by as little as $0.26 \mathrm{~m}$.y. or as much as $0.91 \mathrm{~m}$.y. The two-volcano hypothesis remains a topic worthy of pursuit. Its resolution will depend on some closely linked, detailed magnetostratigraphic observations, radiometric dating, and analytical chemistry.

\section{O’ahu}

O‘ahu was built by three volcanoes. Two of them, Wai'anae and $\mathrm{Ko}^{\prime} \mathrm{olau}$, form the extent of $\mathrm{O}^{`} \mathrm{ahu}$ (island). The third is Ka'ena, also the oldest, whose summit lies beneath the waves on a submarine platform west of $\mathrm{O}^{\prime}$ ahu (fig. 9). Once thought only a rift zone of adjacent Wai'anae, substantial evidence has been compiled to warrant its interpretation as separate volcano (Sinton and others, 2014). Of the exposed volcanoes, Wai'anae is older than the more easterly Ko'olau. Ka'ena, Wai'anae, and Ko‘olau volcanoes have been truncated by massive submarine slides, the Ka'ena Slide on the north side of Ka'ena Ridge, Wai'anae Slump on O'ahu's southwest side, and Nu'uanu Slide on the northeast. Walker (1995) noted the general dearth of plant molds in lava flows of $\mathrm{O}^{\prime}$ ahu volcanoes and suggested that the exposed lava sequences represent the arid, upper 1,000-m remnants of 

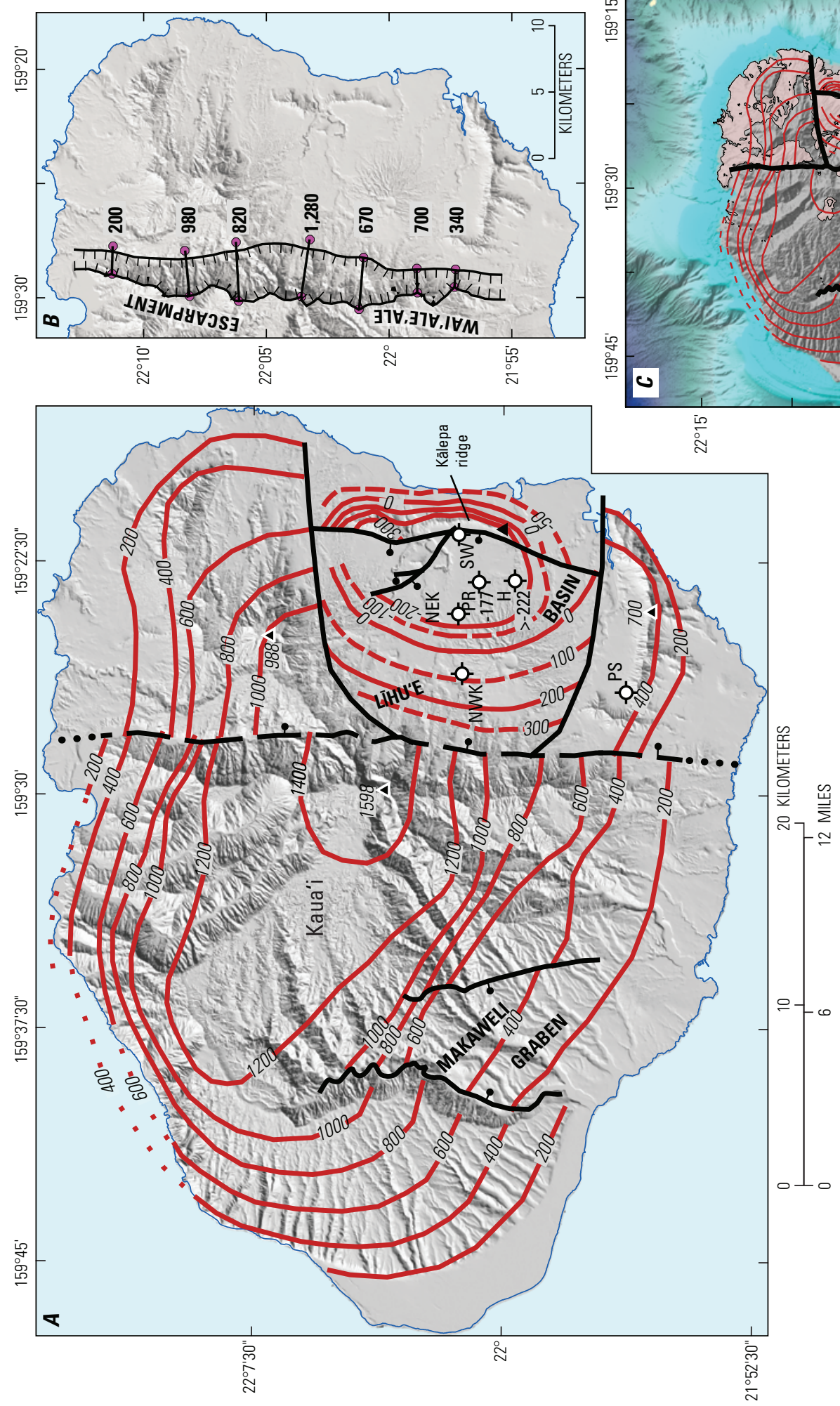

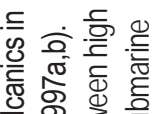

응 总

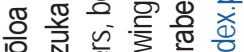

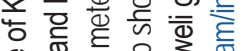

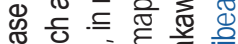

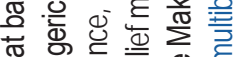

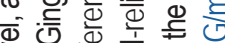

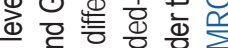

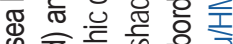

둥 은 훙

品

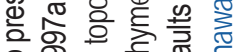

응 휴

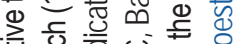

훙 응 능 웅

क 㐘

\% 웡 है है

这 完

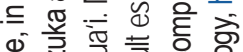

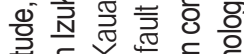

表

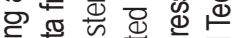

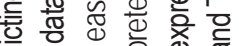

잉히웡

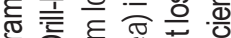

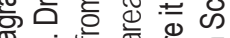

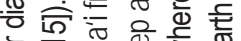

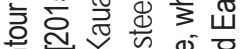

8 잉

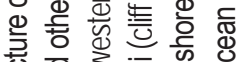

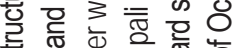

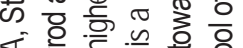

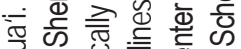

舫

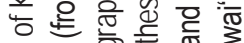

은

증 कृष

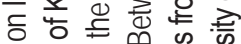

递喜

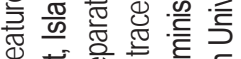

击

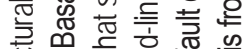

등 요을

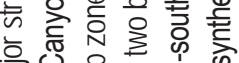

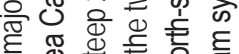

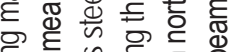

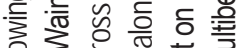

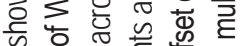

응 苃 흥

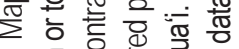

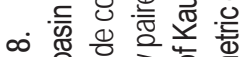

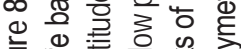

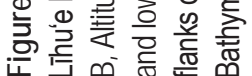


mountains that once projected above the altitude of trade winds (approximately 3,000 $\mathrm{m}$ above present sea level). This interpretation is consistent with the argument that most of the older Hawaiian islands have subsided several thousand meters since formation (Moore, 1987) by their imposition on the underlying oceanic crust.

\section{Ka'ena}

Most of Ka'ena is composed of pillow lavas with ages ranging from 4.9 to $3.6 \mathrm{Ma}$ and chemical composition that distinguishes them from nearby Wai'anae volcano. The base of Ka'ena is at abyssal depths of about $4,600 \mathrm{~m}$, and the present summit lies about $700 \mathrm{~m}$ below sea level. However, samples recovered by remotely operated vehicles from depths shallower than 1,800 m lack pillow structure and are highly vesicular, characteristics that suggest subaerial eruption. Thus, Ka‘ena likely breached sea level late in its eruptive history, about 3.5 Ma, and attained a maximum elevation of about $1,000 \mathrm{~m}$ above sea level. Subaerial lavas include compositionally transitional and alkalic basalt and hawaiite (termed "Ka"ena B" by Sinton and others, 2014), although samples from the shoalest regions are tholeiitic basalt. Thus, the youngest part of the volcano includes mixed alkalic and tholeiitic lava flows, and there is no evidence for a topographic caldera, characteristics typical of the latest shield stage of many Hawaiian volcanoes. The age of youngest volcanism on Ka'ena volcano is poorly known from existing data, an area for further research.

Samples from the Ka'ena Slide deposit (Coombs and others,

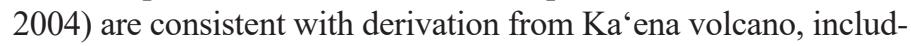
ing some of the younger Ka'ena B compositions, indicating that at least part of the deposit is $3.6 \mathrm{Ma}$ or younger. In contrast, samples from the Wai'anae Slump suggest derivation from Wai'anae volcano, with no evidence for a contribution from Ka'ena.

\section{Wai'anae Volcano-Setting and Stratigraphic Notes}

Wai'anae volcano, the older of the two O'ahu volcanoes above present sea level, is built of the Wai'anae Volcanics, whose four members (Lualualei, Kamaile‘unu, Pālehua, and Kolekole Members) encompass (1) shield-building tholeiitic basalt, (2) a late-shield or transitional phase that includes caldera-filling lava, (3) a dominantly hawaiitic postshield-stage phase, and (4) a later post-erosional, dominantly basaltic postshield phase (fig. 9). The first systematic geologic map of $\mathrm{O}^{\prime}$ ahu (Stearns, 1939) grouped the Wai'anae Volcanics into a single map unit, although informal members were described earlier (Stearns and Vaksvik, 1935) and an upper member (Pālehua and Kolekole Members on our map, sheet 2) was later shown separately on a small-scale map figure (Macdonald, 1940a). In addition, Stearns (1939) recognized the post-erosional character of a lava flow at Kolekole Pass, which he later named as a formal stratigraphic unit (Stearns, 1946).

Sinton (1987) revised the stratigraphic nomenclature for the Wai'anae Volcanics by replacing the former lower, middle, and upper members with newly defined Lualualei, Kamaile'unu, and Pālehua Members. The Kolekole Volcanics was extended to include several lava flows and cinder cones on the southeastern and south flanks of the Wai'anae Range, on the basis of chemical and stratigraphic similarity to the type section at Kolekole Pass (Sinton, 1987). Subsequently it was determined that the age of Kolekole eruptions is barely distinguishable from that of the earlier Pālehua lavas, with the transition occurring about $3 \mathrm{Ma}$, and that the intervening unconformity marked a short-lived event perhaps related to the massive submarine slumping of the west side of the Wai'anae volcano (Presley and others, 1997). As a consequence, the Kolekole Volcanics unit is now thought to represent a continuation of postshield volcanism that began with the eruptions of the Pālehua Member, and not the product of a separate, rejuvenated-stage volcanic episode. For these reasons, Presley and others (1997) chose to reduce the rank of the Kolekole Volcanics from formation to member and to include it in the encompassing Wai'anae Volcanics.

More recent mapping has further clarified the outcrop areas of Pālehua and Kolekole Members of the Wai'anae Volcanics (sheet 2). The combined outcrop area of these postshield members is more areally restricted on our map than in the depiction of the upper member of Stearns (1939) and Macdonald (1940a), with most of the difference lying along the range crest northwest of Ka'ala summit.

The Wai'anae Volcanics have radiometric ages ranging from about 4.0 Ma to as young as about 2.9 Ma. A few younger ages were reported by Doell and Dalrymple (1973), but we interpret those ages as too young, in view of the more complete dating and stratigraphic information available today (fig. 10). The period between 4 and 3 Ma was one of frequent magnetic polarity reversals spanning parts of the Gilbert and Gauss Chrons, including the Mammoth and Ka'ena Reversed-Polarity Subchrons within the Gauss Normal-Polarity Chron (Ogg and Smith, 2004). The combination of relatively easy access, numerous magnetic reversals, 80 radiometric ages (McDougall, 1963, 1964; Funkhouser and others, 1966, 1968; Doell and Dalrymple, 1973; Presley and others, 1997; Laj and others, 1999; Guillou and others, 2000), and advanced stage of erosion on the leeward (dry) side of $\mathrm{O}^{\text {' }}$ ahu has allowed a fairly precise stratigraphic resolution of the volcano.

The oldest exposed lava flows in the Lualualei Member are tholeiitic olivine basalt that have reversed polarity magnetization and radiometric ages ranging from slightly older than about 3.9 to as young as $3.55 \mathrm{Ma}$. A well-developed caldera near Lualualei valley was present throughout the eruption of the Lualualei lava flows, as was a well-developed rift zone trending approximately N. $60^{\circ}$ W. from near Kolekole Pass. Another lesser rift zone runs southeast from the head of Lualualei valley, which marks the volcano's center, but its dikes trend along a more radial pattern as they swing around the south side of the caldera. The radial pattern is perhaps in response to the stress field created by caldera growth (Zbinden and Sinton, 1988), or possibly because this part of the volcano lacked buttressing by the underlying $\mathrm{Ka}$ 'ena volcano, on which the Wai'anae volcano was built (Sinton and others, 2014). A poorly developed third rift zone trends approximately N. $65^{\circ} \mathrm{E}$. from the volcanic center (Stearns and Vaksvik, 1935).

The Kamaile‘unu Member, erupted during a later shieldbuilding stage lasting from 3.55 to $3.06 \mathrm{Ma}$, is characterized by increasing variability of lava composition, including plagioclasephyric tholeiitic basalt, alkali olivine basalt, and alkalic, plagioclase-phyric hawaiite (composition on the basalt-hawaiite boundary, fig. 11). Eruptions of Kamaile'unu lava flows occurred within 

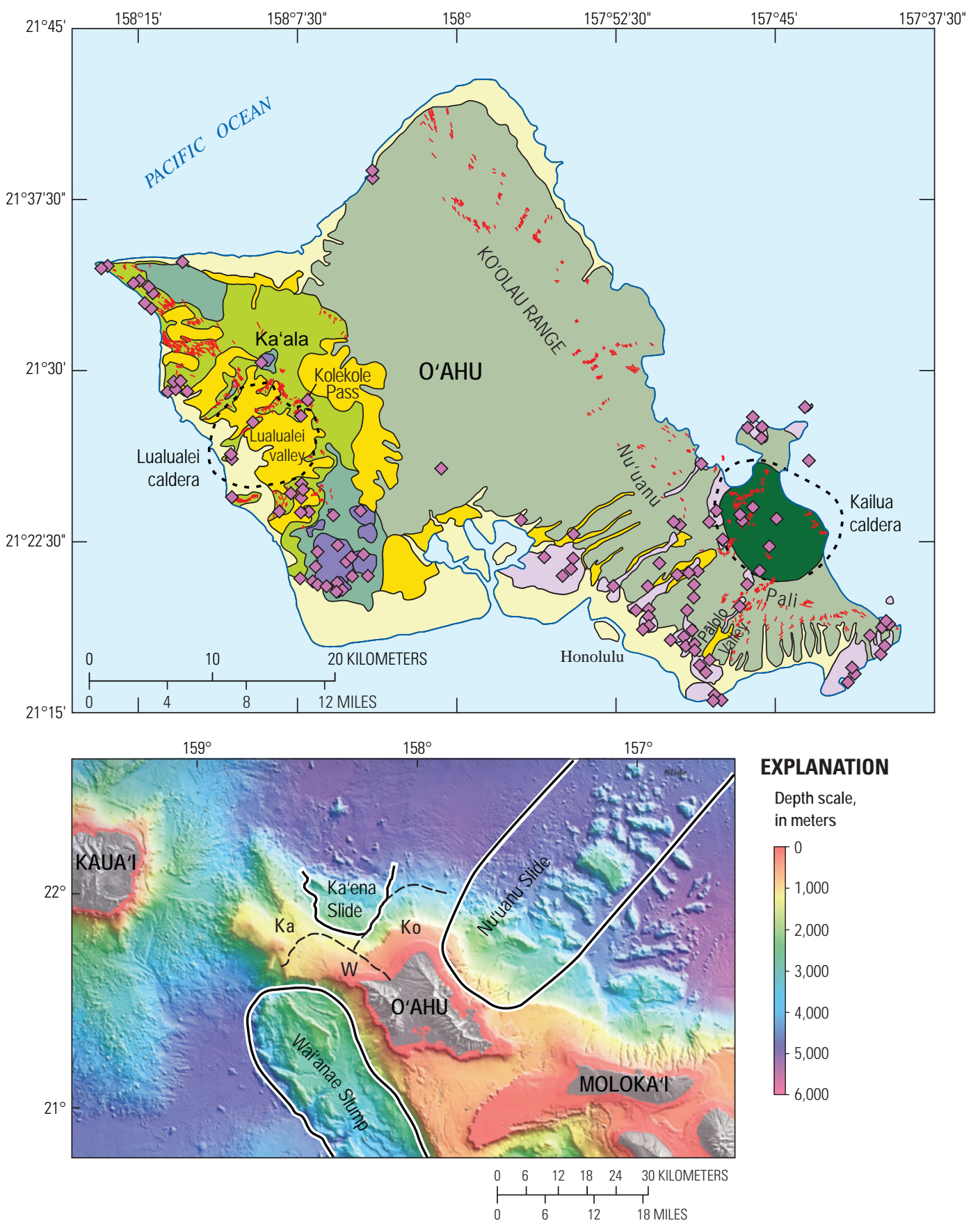

EXPLANATION

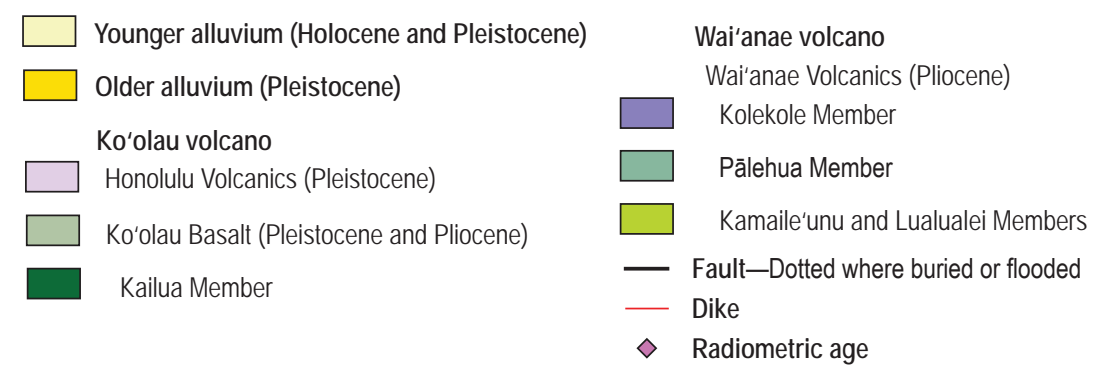

Figure 9. Geologic map of O'ahu, generalized from this publication's digital map database. Geology from Stearns (1939) and J.M. Sinton (sheet 2). Bathymetric map (at bottom) from Eakins and others (2003). Dashed lines on bathymetric map illustrate the physiographic boundaries between Ka'ena volcano (Ka, seaward) and the Wai'anae (W) and Ko'olau (Ko) volcanoes (landward) (Sinton and others, 2014). 


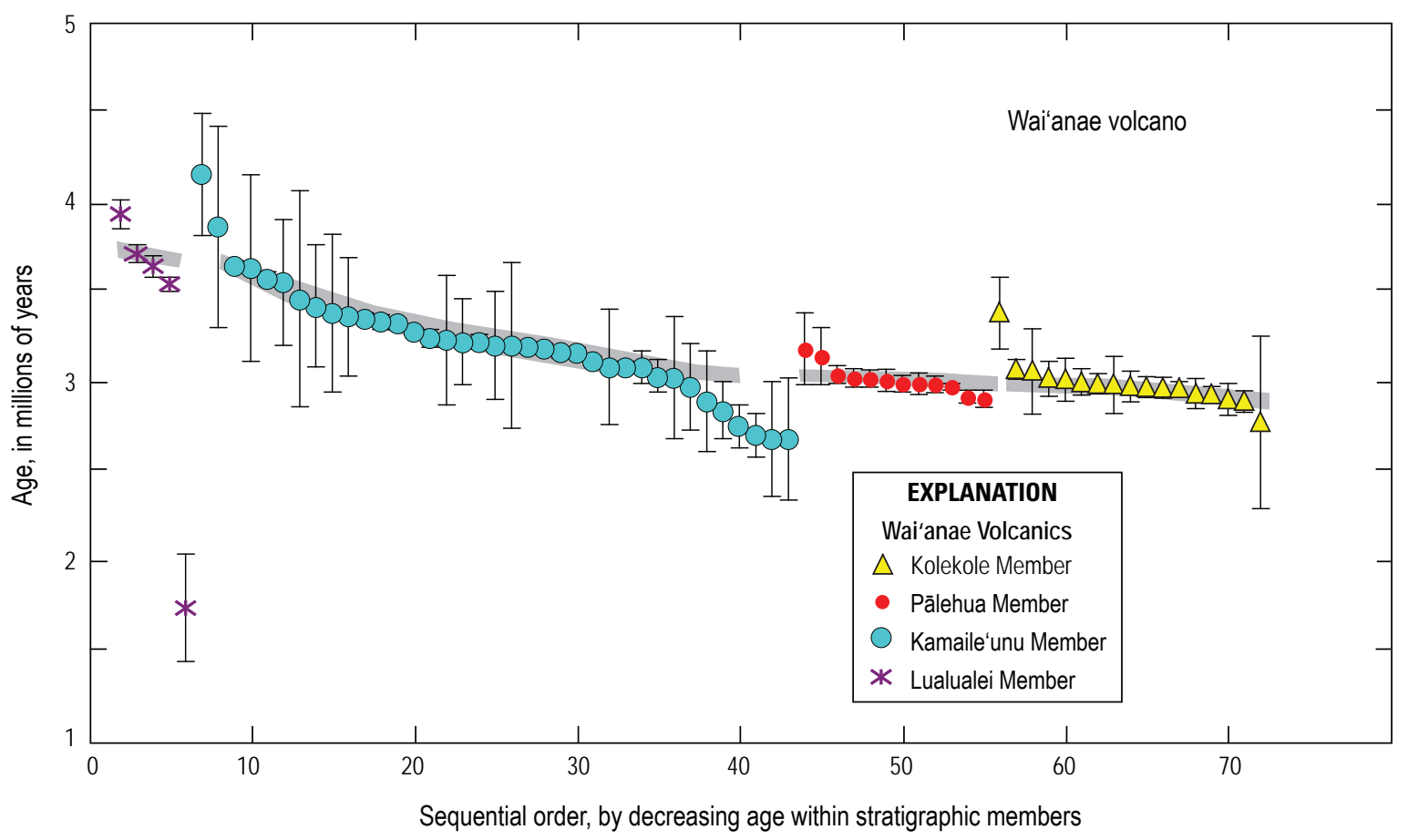

Figure 10. Radiometric ages from Wai'anae volcano, Island of O'ahu. Gray bands indicate likely range of stratigraphically valid ages, as a guide to recognizing ages too old or too young. Data from McDougall (1964), McDougall and Aziz-ur-Rahman (1972), Doell and Dalrymple (1973), Presley and others (1997), Laj and others (1999), and Guillou and others (2000).

the caldera and along rift zones outside the caldera. The caldera eventually was filled by Kamaile'unu lava flows, so this period can be viewed as a caldera-filling episode. Alkalic lava flows become increasingly abundant in Kamaile'unu sections younger than about 3.207 Ma, the upper boundary of the Mammoth Reversed-Polarity Subchron (Ogg and Smith, 2004). Silicic lava, including icelandite (Al-poor, Fe-rich andesite) and rhyodacite (fig. 11), is exposed as intracaldera dikes and flows. Radiometric ages for the Mauna Kūwale Rhyodacite Flow range from $2.4 \pm 0.3 \mathrm{Ma}$ (Funkhouser and others, 1966, 1968) to about $8.4 \mathrm{Ma}$ (McDougall, 1964), but the eruption of this unit is now known to have occurred close to the lower boundary of the Mammoth Reversed-Polarity Subchron, about 3.3 Ma (Guillou and others, 2000). The Mauna Kūwale Rhyodacite Flow, which contains 68 percent $\mathrm{SiO}_{2}$, is the most silicic lava composition reported from the Hawaiian island chain, and the Wai'anae volcano is remarkable for its eruptions of highly evolved lava emplaced during the shield stage. Lead isotopic ratios of the Mauna Kūwale rhyodacite are similar to those of the under-

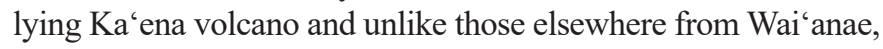
which suggests that the Mauna Kūwale rhyodacite was derived in part from partial melting of the lower ( $\mathrm{Ka}^{\prime} \mathrm{ena}$ ) crust beneath Wai'anae volcano (van der Zander and others, 2010).

The postshield cap of the volcano comprises the Pālehua and Kolekole Members. They possess mainly normal-polarity magnetization younger than the Ka'ena subchron's younger boundary, about $3.04 \mathrm{Ma}$, although rare reversed-polarity Pālehua lavas have been found near the base of the postshield section. The Pālehua Member includes hawaiite and mugearite. The overlying Kolekole Member, the "last gasp" of the Wai'anae volcano, marks a return to basaltic eruptions (fig. 11); it also commonly contains xenoliths of lower crustal dunite, pyroxenite, and gabbro. The Kolekole Member is separated from the Pālehua Member by a substantial erosional disconformity, but their difference in age is barely distinguishable; the transition occurred about $2.98 \mathrm{Ma}$ (Presley and others, 1997). Thus, the profound erosional event separating Pālehua and Kolekole Members, although short lived, correlates with a substantial decrease in the amount of magmatic differentiation.

A huge landslide has been suggested as a mechanism to precipitate the major erosional episode prior to Kolekole time, with the evidence preserved as the Wai'anae Slump (Presley and others, 1997). Covering roughly $5,500 \mathrm{~km}^{2}$, the Wai'anae Slump is one of the larger submarine landslides associated with the Hawaiian Islands (bathymetric map, fig. 9). It contains features thought typical of a slumplike landslide with a complicated and possibly prolonged history (Moore and others, 1989; Coombs and others, 2004). By one interpretation, the Wai'anae Slump occurred prior to Pālehua time (before about 3.06 Ma), inasmuch as no alkalic rocks have been collected from the slump (Coombs and others, 2004). The slump is sparsely sampled, however, owing to the ominous plexus of telecommunication cables that traverse the region. Also, the volcano's capping alkalic strata are likely thin, and most of the slump is derived from the submarine flanks of the volcano, which is broadly tholeiitic in composition. Thus, an age estimate derived on the basis of recovered rock types might be judged cautiously. But in view of the arguments for multiple events contributing to the Wai'anae Slump (Coombs and others, 2004), the Kolekole-related subaerial erosion and deposition about 2.98 Ma might be one in a series of mass-wasting events that affected the Wai'anae volcano. 


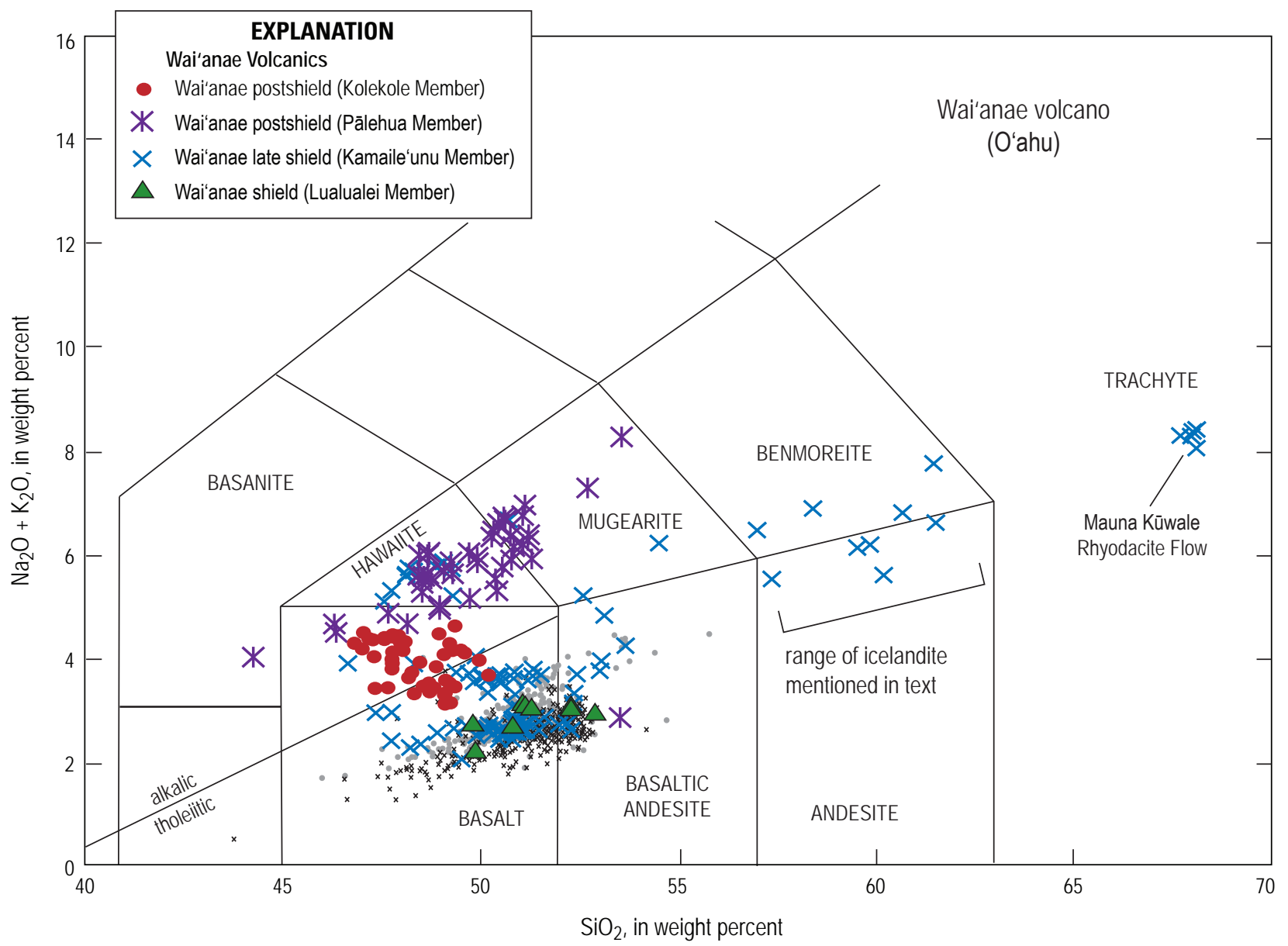

Figure 11. Alkali-silica $\left(\mathrm{Na}_{2} \mathrm{O}+\mathrm{K}_{2} \mathrm{O}\right.$ versus $\left.\mathrm{SiO}_{2}\right)$ diagram for analyzed rocks from Wai'anae volcano, O'ahu. Grid boundaries and Mauna Loa-Kïlauea data (small black $x$ and gray dot symbols) are referenced in figure 2 caption. Wai'anae chemical data from J.M Sinton and G.A. Macdonald (Bishop Museum's online database, 72 analyses), Macdonald and Katsura (1964, 50 analyses), T.K. Presley (Bishop Museum's online database, 48 analyses), Presley and others (1997, 18 analyses), Sinton (1987, 4 analyses), Macdonald (1968, 2 analyses), and Bauer and others (1973, 2 analyses).

\section{Ko'olau Volcano-Setting and Stratigraphic Notes}

The Ko'olau Range is the western dip slope and core of Ko'olau volcano (fig. 9). About 12 percent of the east half of the volcano has been carved away by large submarine landslidesspecifically, $2-4 \times 10^{3} \mathrm{~km}^{3}$ from a volcano originally containing about $25 \times 10^{3} \mathrm{~km}^{3}$ (Satake and others, 2002; Sinton and others, 2014, respectively).

Volcanic strata of the shield stage are assigned to the Ko'olau Basalt, a sequence of tholeiitic basalt lava flows (fig. 12). They $\operatorname{dip} 3^{\circ}-10^{\circ}$ west and southwest from the summit of the Ko'olau Range; thus the east face of the range is an anti-dip slope exposing about $850 \mathrm{~m}$ of the Ko'olau Basalt. A prominent northwesttrending rift zone is defined by a dike complex on the east side of the range (Stearns, 1939). Ease of access and good exposures make it the best studied dike complex in the Hawaiian Islands. Comparable zones on West Maui and East Moloka' $i$ lie in rugged terrain that lacks roads or trails. The dike complex, containing more than 7,400 subparallel dikes in a zone 3-5 km wide, is mapped as a separate part of the Ko'olau Basalt, owing to the abundance of dikes (greater than 40 percent) in much of the area it covers (Walker, 1987). The boundary between dike complex and the main mass of the Ko'olau Basalt, although shown by a distinct line on sheet 2, is a gradational zone in which the number of dikes diminishes outward from the core of the dike complex.

A caldera complex, the Kailua caldera, also formed during shield-stage volcanism. Its rocks are assigned to the Kailua Member of the Ko'olau Basalt, and they demarcate a roughly equant caldera 9-10 km in diameter (fig. 9) (Stearns, 1939; Walker, 1987).

The oldest ages for subaerially emplaced Ko'olau Basalt are about $3 \mathrm{Ma}$, as determined from surface exposures and from samples obtained by drilling (Ozawa and others, 2005, and Haskins and Garcia, 2004, respectively) (fig. 13). The youngest age from the Ko'olau Basalt is $1.78 \pm 0.26 \mathrm{Ma}$ (Doell and Dalrymple, 1973), although Ozawa and others (2005) argued that Ko'olau volcanism ended approximately 2.1-2.0 Ma, on the basis of the analytical error associated with their newly obtained ages. An age of $1.59 \pm 0.13 \mathrm{Ma}$ from one of several flows sampled near the southeast end of the Ko'olau Range was reported by Doell and Dalrymple (1973), who regarded it skeptically. Other samples gathered from that sample set range in age from 2.30 to $1.75 \mathrm{Ma}$, and of those, only two lava flows had ages that could be reproduced satisfactorily through several experimental determinations (Doell and Dalrymple, 1973). 
Scattered sporadically above the Ko‘olau Basalt are lava flows and vent deposits of the Honolulu Volcanics (fig. 9). Interpreted as products of rejuvenated-stage volcanism, the Honolulu Volcanics contains several of Hawai'i's best known vents, such as Diamond Head, Punchbowl crater, Salt Lake crater, and Koko Head. The individual eruptive units have had names applied to them in the past, and we carry those into the geologic map digital database and treat them as informally named parts of the Honolulu Volcanics, as recommended by Langenheim and Clague (1987). Some vents of the Honolulu Volcanics form alignments transverse to the rift zone that built the Ko'olau shield (for example, Stearns and Vaksvik, 1935; Winchell, 1947).

The Honolulu Volcanics have K-Ar ages that range from about 0.80 to somewhat younger than $0.1 \mathrm{Ma}$, according to a recent, detailed analysis of the unit's emplacement history (Ozawa and others, 2005) (fig. 13). Previously determined ages indicated a similar span of time, although two ages were slightly older, about 1.1-1.0 Ma (Lanphere and Dalrymple, 1980), and two other ages were much too old to make sense stratigraphically (Lanphere and Dalrymple, 1980). As can be seen in the inset for figure 13, some of the youngest reported radiometric ages
(Gramlich and others, 1971) are unrealistically precise for the methods available when the work was done.

In keeping with the mapping of Stearns (1939), this geologic map subdivides the Honolulu Volcanics to show separately its youngest deposits, those from the Tantalus Peak-Sugarloaf vent system and the Koko fissure system. As dated by Ozawa and others (2005), these volcanic deposits are distinctly younger than earlier parts of the Honolulu Volcanics. Their ages form a suite chiefly about 0.1 Ma but perhaps as young as 0.04 Ma when analytical error is considered. The older part of the Honolulu Volcanics is chiefly older than about 0.4 Ma (Ozawa and others, 2005).

Reports that the Honolulu Volcanics includes volcanic rocks with ages younger than 30,000 years probably arise from misinterpretations of the data. For example, eruptions from craters in the Koko fissure system were assigned an age between 32,000 and 7,000 years by Hazlett and Hyndman (1996). As best we can tell, the 32,000-yr age originated from the radiocarbon dating of coral fragments within the ash deposits. The result was an age greater than 32,000 years (Rubin and Suess, 1956), by which was meant a sample too old to date by radiocarbon methods at that time. The 7,000-yr age results from radiocarbon dating of reef

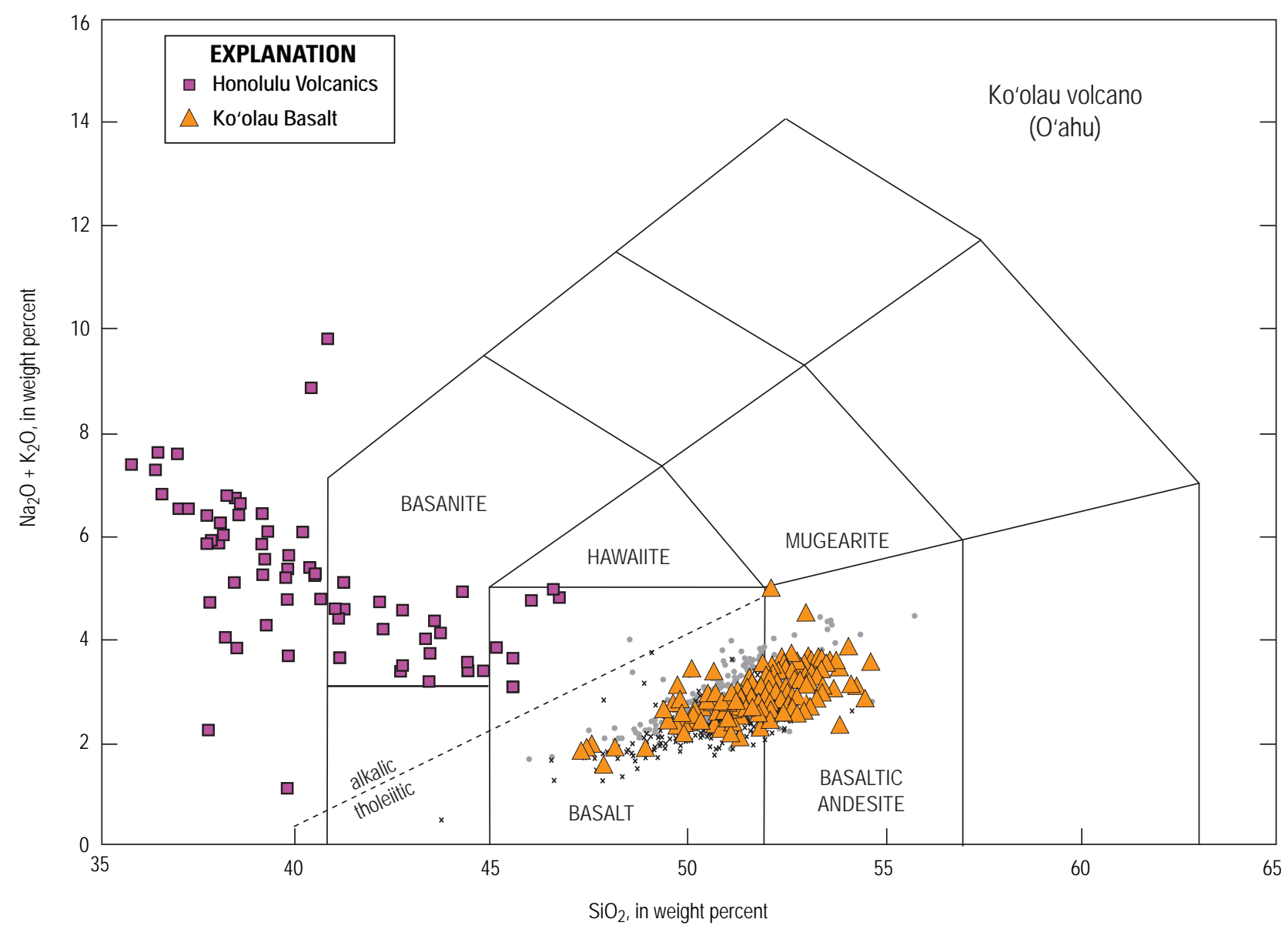

Figure 12. Alkali-silica $\left(\mathrm{Na}_{2} \mathrm{O}+\mathrm{K}_{2} \mathrm{O}\right.$ versus $\left.\mathrm{SiO}_{2}\right)$ diagram for analyzed rocks from Ko'olau volcano, O’ahu. Grid boundaries and Mauna Loa-Kīlauea data (small black $x$ and gray dot symbols) referenced in figure 2 caption. Ko'olau chemical data from Haskins and Garcia (2004, 118 analyses), Frey and others (1994, 71 analyses), Clague and Frey (1982, 41 analyses), Jackson and Wright (1970, 13 analyses), Roden and others (1984, 12 analyses), Macdonald (1968, 10 analyses), Wentworth and Winchell (1947, 9 analyses), Winchell (1947, 8 analyses), Wilkinson and Stolz (1983, 8 analyses), Yoder and Tilley (1962, 4 analyses), Muir and Tilley (1963, 2 analyses), T.K. Presley (Bishop Museum's online database, 2 analyses), Cross (1915, 1 analysis), and Macdonald and Katsura (1964, 1 analysis). 


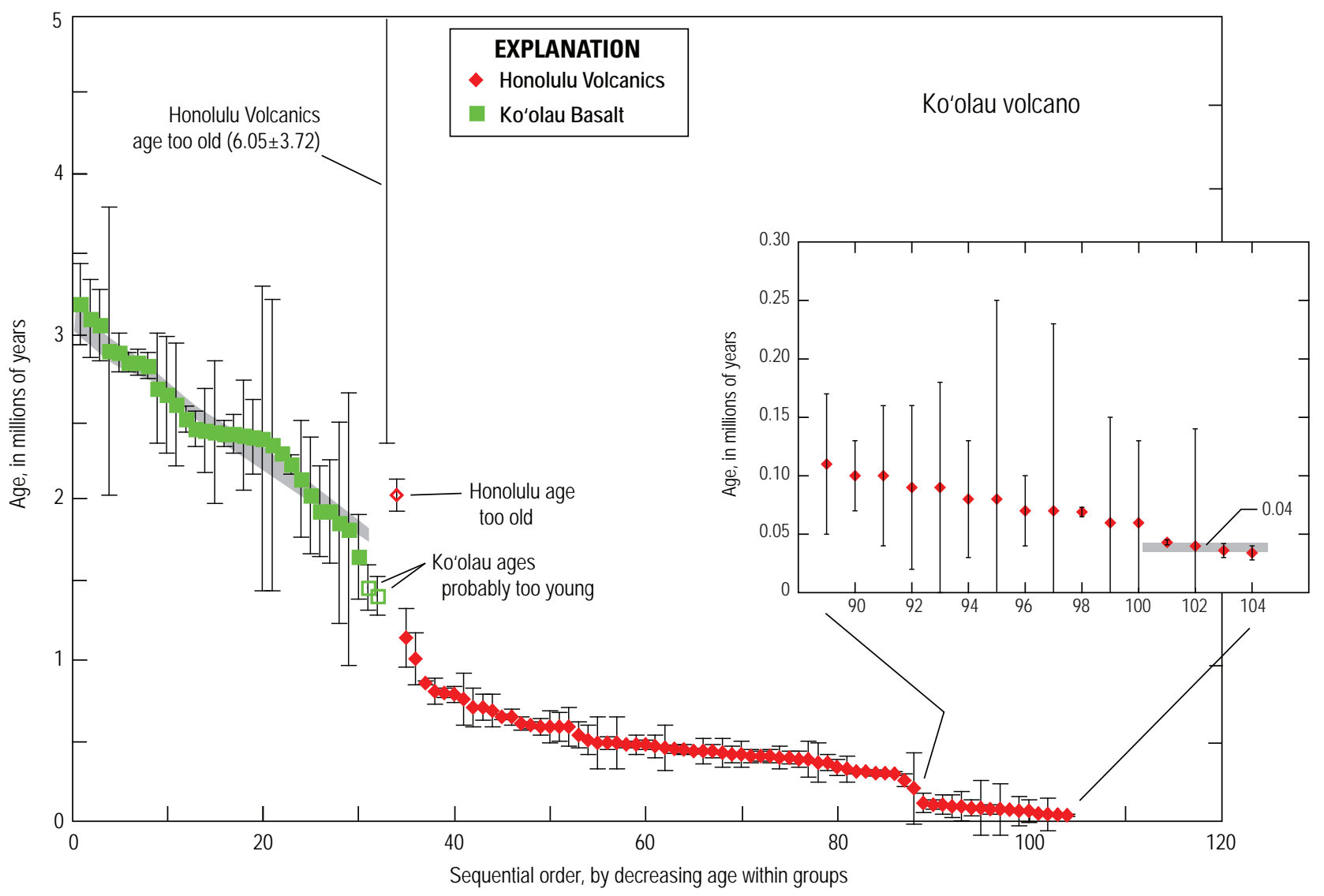

Figure 13. Radiometric ages from Ko'olau volcano, O'ahu. Open symbols denote ages likely too old or too young; see text for discussion. Labeled parenthetically is an exceptionally old age from Honolulu Volcanics, for which only the lower part of the error bar shows on range of this graph. Inset is enlargement showing 16 youngest ages from Honolulu Volcanics. Data from McDougall (1964), Gramlich and others (1971), McDougall and Aziz-ur-Rahman (1972), Doell and Dalrymple (1973), Stearns and Dalrymple (1978), Lanphere and Dalrymple (1980), Haskins and Garcia (2004), and Ozawa and others (2005).

growing on the Koko fissure deposits (Easton and Olson, 1976); thus, it is a minimum age that provides no better constraint than the 32,000-yr minimum age.

An age younger than 10,000 yr was reported for the Sugarloaf flow, a Honolulu Volcanics lava that spread out across the mouth of Mānoa Valley (Hazlett and Hyndman, 1996). This age is an interpretation that hinges on a string of assumptions by Ferrall (1981) about the age of interbedded alluvium and ash deposits that fill an ancestral Mānoa stream channel now flooded by the lava flow; no radiometric data were forthcoming. The Sugarloaf flow has been dated by K-Ar methods. In one case it produced a weighted mean age of about $0.069 \pm 0.004 \mathrm{Ma}$ (Gramlich and others, 1971); in the other, a weighted mean age of $0.11 \pm 0.13 \mathrm{Ma}$ (Ozawa and others, 2005). More recently this flow has been dated using high-precision ${ }^{40} \mathrm{Ar} /{ }^{39} \mathrm{Ar}$ methods (Clague and others, 2016), yielding a weighted mean age of $76 \pm 4 \mathrm{ka}$.

\section{Nưuanu Pali}

One of the most striking geomorphologic features in the Hawaiian Islands is the great northeast-facing cliff that extends for more than $40 \mathrm{~km}$ along the present-day crest of the Ko'olau volcano. This sheer precipice ranges in height from about 150 to $800 \mathrm{~m}$ above the surrounding terrain. The pali originated mainly by subaerial fluvial erosion (Stearns and Vaksvik, 1935; Macdonald and others, 1983). Structural origins have been proposed (for example, Dana, 1890) but refuted because stratigraphic units exposed at the foot of the pali extend eastward across the abruptly lower terrain. Also, the Ko'olau dike complex (Walker, 1987) is undisturbed. The missing eastern part of the volcano, mentioned in our introduction to Ko'olau, is now marked by the Nu'uanu Slide. This great debris avalanche has a landslide head thought to coincide with an arcuate embayment in the submarine bathymetric contours $15 \mathrm{~km}$ northeast of the present shoreline (bathymetric map, fig. 9) (Moore and Clague, 2002).

As recognized by Stearns and Vaksvik (1935), it is an oversimplification to say that faulting and caldera structures played no role whatsoever in the formation of the pali. Fluvial erosion may have been enhanced by caldera-related structures, and hydrothermally altered rocks near the ancient caldera may have been highly susceptible to removal by erosion. Nevertheless, the pali extends far beyond the western edge of the Ko'olau caldera, and it is characterized along its entire length by a pattern of scallops that resemble coalesced amphitheater heads of a Hawaiian stream valley. The coincidence of the pali and the main Ko'olau rift zone suggests the numerous dikes influenced the pattern of erosion, perhaps by controlling the volcano's permeability to ground water on its windward side. 


\section{Moloka'i}

Moloka' $i$ was built by the lava flows assigned to East Moloka' $i$ and West Moloka'i volcanoes. The island today is elongate, roughly $60 \mathrm{~km}$ long and only $15 \mathrm{~km}$ wide, but it was probably somewhat more equant earlier in its history, before the Wailau Slide chopped off the north half of the island (sheet 3; fig. 14).

\section{West Moloka'i Volcano}

West Moloka'i is a low-lying volcano whose highest point is only about $437 \mathrm{~m}$ at the Kukui benchmark. Most exposures are of thin-bedded basaltic lava flows typical of shield-stage volcanism. As summarized by Stearns and Macdonald (1947), southwest and northwest rift zones are inferred from the $2^{\circ}-10^{\circ}$ dip of lava flows away from the rift zone axes. The northwest rift zone's trace is further defined by northwest-striking dikes exposed in sea cliffs along the northwest shore of the island. The southwest rift zone is customarily drawn to coincide with a broad ridge trending west-southwest away from the summit area, where a few westsouthwest-striking dikes and several vents have been mapped, to Là'au Point. The rift zone likely extends west-southwest offshore of Moloka' $i$ along the submerged landmass locally known as "Penguin Bank." Across much of the volcano, the lava flows have weathered so deeply that little original structure can be recognized. Given the low topographic relief, gentle dips of lava, and shallow incision of the volcano, it is unlikely that more than $100 \mathrm{~m}$ of stratigraphic sequence is exposed in the gulches and coastal cliffs of West Moloka'i.

All volcanic rocks from West Moloka'i were grouped into the West Moloka'i Volcanics stratigraphic unit by Stearns and Macdonald (1947). They depicted the distribution of late lava flows in a small-scale figure (Stearns and Macdonald, 1947, their fig. 18), which forms the basis for an informally named map unit "Wai'eli and other late lava flows" in an earlier version of this map publication (Sherrod and others, 2007b). Recent mapping of West Moloka'i (Sinton and others, 2017; fig. 14) identified some $30 \mathrm{~km}^{2}$ of alkalic basalt and hawaiite (fig. 15) that has now been designated formally as Wai'eli Volcanics, which represents the postshield sequence overlying the now slightly restricted West Moloka'i Volcanics shield sequence. No rejuvenated-stage deposits are known from West Moloka'i.

Radiometric ages from West Moloka'i are limited. The top of the shield section is about $1.8 \mathrm{Ma}$, which is in agreement with ages and magnetic polarity determinations on the underlying shield lavas and overlying postshield samples (McDougall, 1964; Clague, 1987a; Sinton and others, 2017; fig. 16). Another suite of six ages, which range from about 2.8 to $1.3 \mathrm{Ma}$ (Naughton and others, 1980), include some ages with large analytical error and ages that create apparent stratigraphic inversion - in which the older age is from the stratigraphically higher lava at some localities.

The eastern edge of the West Moloka'i volcano is terminated by a fault zone with displacement of at least $150 \mathrm{~m}$. The lava from East Moloka' $i$ volcano has filled in the downdropped area, banked against the fault zone, and lapped across it onto the West Moloka' $\mathrm{i}$ lava flows.

In compiling this geologic map, we found a substantial southern expansion of the coastline in the area west of Kaunakakai during the past 60 years. Areas shown as tidal flats and open ocean on the 1922 topographic base map have been filled in by mud eroded from upland sites. The progression was already well established by 1935 , when H.T. Stearns first started the Moloka'i geologic mapping. In their text, Stearns and Macdonald (1947) describe the burial of the shoreward part of a fringing reef along the island's south coast, the result of red mud carried seaward as a result of overgrazing in the previous 150 years. Many of the ancient Hawaiian fishponds were partly filled with mud during that time. Today, our map shows 4 $\mathrm{km}^{2}$ of subaerial mudflats not found on the original geologic map, a new-land area only slightly less than that created on the Island of Hawai'i $\left(4.3 \mathrm{~km}^{2}\right)$ during the past 33 years by lava entering the sea from Kîlauea Volcano between 1986 and 2019.

\section{East Moloka'i Volcano}

East Moloka'i volcano, covers two thirds of the island (fig. 14). The north half of the volcano is missing, but its remainder suggests that the volcano likely had an east-west elongation, perhaps the basis for the suggestion that rift zones extend westnorthwest and east-northeast away from the summit area (Fiske and Jackson, 1972). The west-northwest rift zone may have additional basis arising from a broad alignment of vents that trend in this direction and a few dikes mapped in sea cliffs along its trend. Neither rift zone was postulated by Stearns and Macdonald (1947).

A caldera complex high in the shield-stage lava flows was interpreted on the basis of anomalously thick lava flows, talus breccia, and intrusive stocks and plugs (Stearns and Macdonald, 1947). A subsequent investigation into the paleomagnetic stratigraphy of the East Moloka'i volcano led to the interpretation that the caldera may have been substantially larger, $11 \mathrm{~km}$ in diameter (Holcomb, 1985). The western margin of this larger caldera coincides with a late-shield pit crater mapped by Stearns and Macdonald (1947) at Hā'upu Bay. We view Holcomb's (1985) caldera skeptically and retain the structural depiction by Stearns and Macdonald (1947) until a more rigorous examination of northslope stratigraphy is undertaken.

The East Moloka'i Volcanics was divided into lower and upper members by Stearns and Macdonald (1947). In our opinion these designations were formal in status, inasmuch as a type section was named and the units were described thoroughly and depicted on a published map with topographic base at suitable scale-meeting far more requirements than is characteristic of many stratigraphic units formalized later in the 20th and into the 21st centuries. Modern usage, however, considers the members informally named (for example, Langenheim and Clague, 1987, or USGS online GEOLEX database, http://ngmdb.usgs.gov/Geolex/geolex_home.html). Perhaps the confusion arises from the lack of a geographic term in the stratigraphic name. Regardless, we adhere to the modern use of informally named members when describing the East Moloka'i Volcanics.

The lower member consists of tholeiitic, transitional, and alkalic basalt (fig. 15). Its oldest reported age is $1.75 \pm 0.14 \mathrm{Ma}$, from a sample collected about $250 \mathrm{~m}$ below the shield-postshield contact along Hālawa Stream at the east end of the island (fig. 14) (Naughton and others, 1980). Radiometric ages of about $1.52 \mathrm{Ma}$ were obtained from two closely spaced samples near the top of the lower member along the trail to Kalaupapa, and an age from 




Figure 14. Geologic map of Moloka'i, generalized from this publication's digital map database. Geology from Stearns and Macdonald (1947) and J.M. Sinton (this map). Bathymetric map (at top) from Eakins and others (2003).

postshield strata upslope just above the contact was only slightly younger, about 1.49 Ma (McDougall, 1964; ages recalculated using modern decay constants). Newer, more precise ages confirm the age of the boundary between the lower and upper members to be about 1.52 Ma (Sinton and others, 2017). Two other samples higher in the postshield sequence on the southwest flank yielded ages of 1.39 and $1.35 \mathrm{Ma}$ (McDougall, 1964), now extended to $1.31 \mathrm{Ma}$ (Sinton and others, 2017).

Upper member postshield strata as thick as $520 \mathrm{~m}$ are preserved on the summit and flanks of the East Moloka'i volcano. The lava flows are ' $a$ 'ā that range from basanite to benmoreite (fig. 15). They were erupted from cinder cones and thick bulbous domes.
Perhaps the best-known single volcanic feature of East Moloka' $i$ is the small shield vent of Kalaupapa that grew along the northern sea cliffs after the island's last major landslide (fig. 14). The peninsula's lava flows, the Kalaupapa Volcanics, are thought to represent a single, monogenetic lava shield erupted from a vent now marked by a small prominent crater, Kauhakō (Stearns and Macdonald, 1947; Walker, 1990). Another vent about $1.6 \mathrm{~km}$ southwest was described by Coombs and others (1990). Its deposits, included here with the Kalaupapa Volcanics, lie plastered on the base of East Molokai's prominent cliff at about the 200-m altitude. They lack obvious topographic expression, have not been mapped except by a mark on a sketch figure, and have not been 


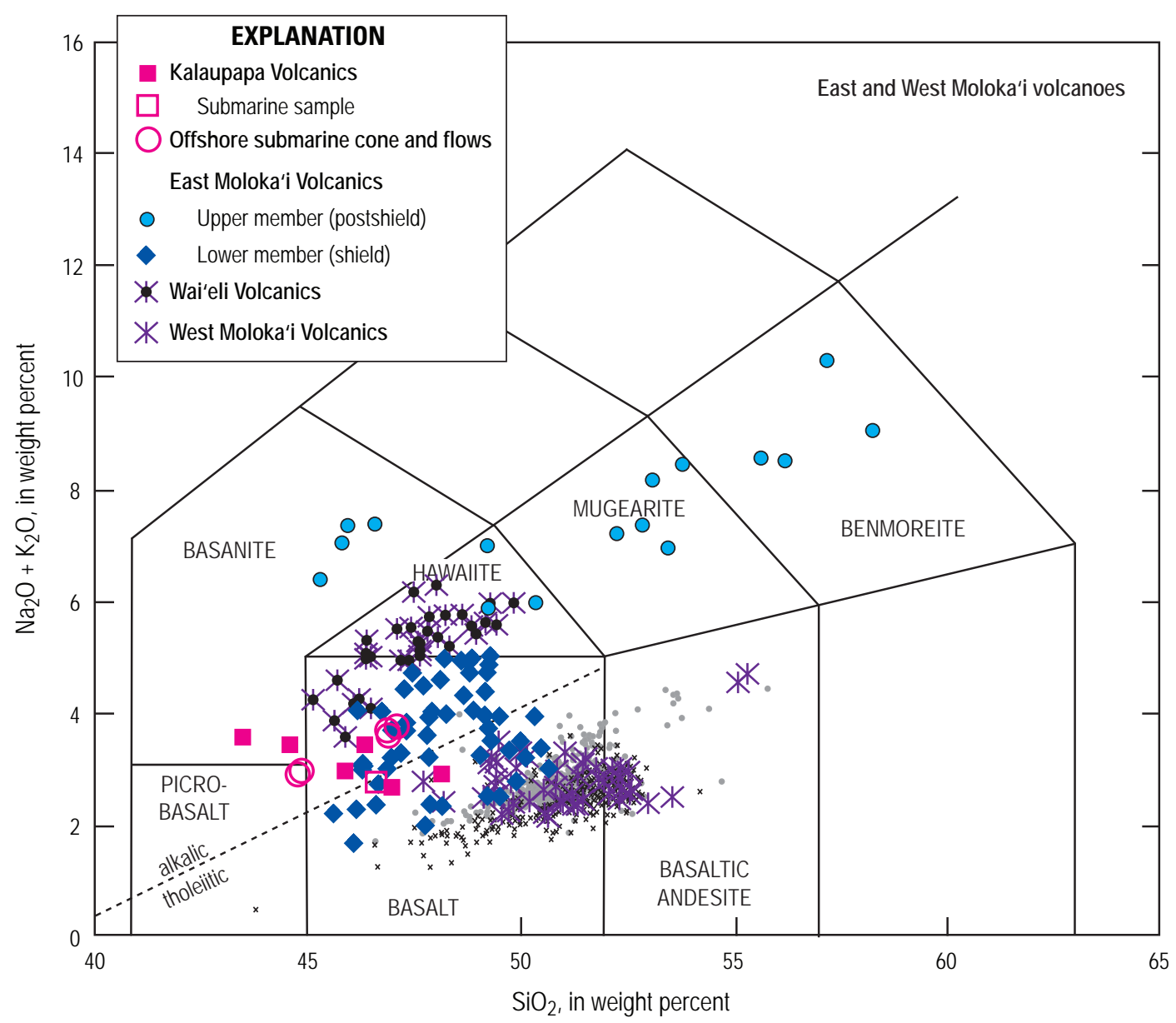

Figure 15. Alkali-silica $\left(\mathrm{Na}_{2} \mathrm{O}+\mathrm{K}_{2} \mathrm{O}\right.$ versus $\left.\mathrm{SiO}_{2}\right)$ diagram for analyzed rocks from Moloka'i. Grid boundaries and Mauna LoaKīlauea data (small black $x$ and gray dot symbols) referenced in figure 2 caption. Moloka'i chemical data from Sinton and others (2017, 67 analyses), Guangping Xu and others (2005, 39 analyses), Beeson (1976, repeated in Clague and Beeson, 1980, 26 analyses), Potter (1976, 20 analyses), Clague and Moore (2002, 10 analyses), Macdonald (1968, 5 analyses), Clague and others (1982, 5 analyses), Macdonald and Katsura (1964, 2 analyses), Sinton and Sinoto (1997, repeated in Sinton and others, 2017, 2 analyses), and Stearns and Macdonald (1947, 1 analysis).

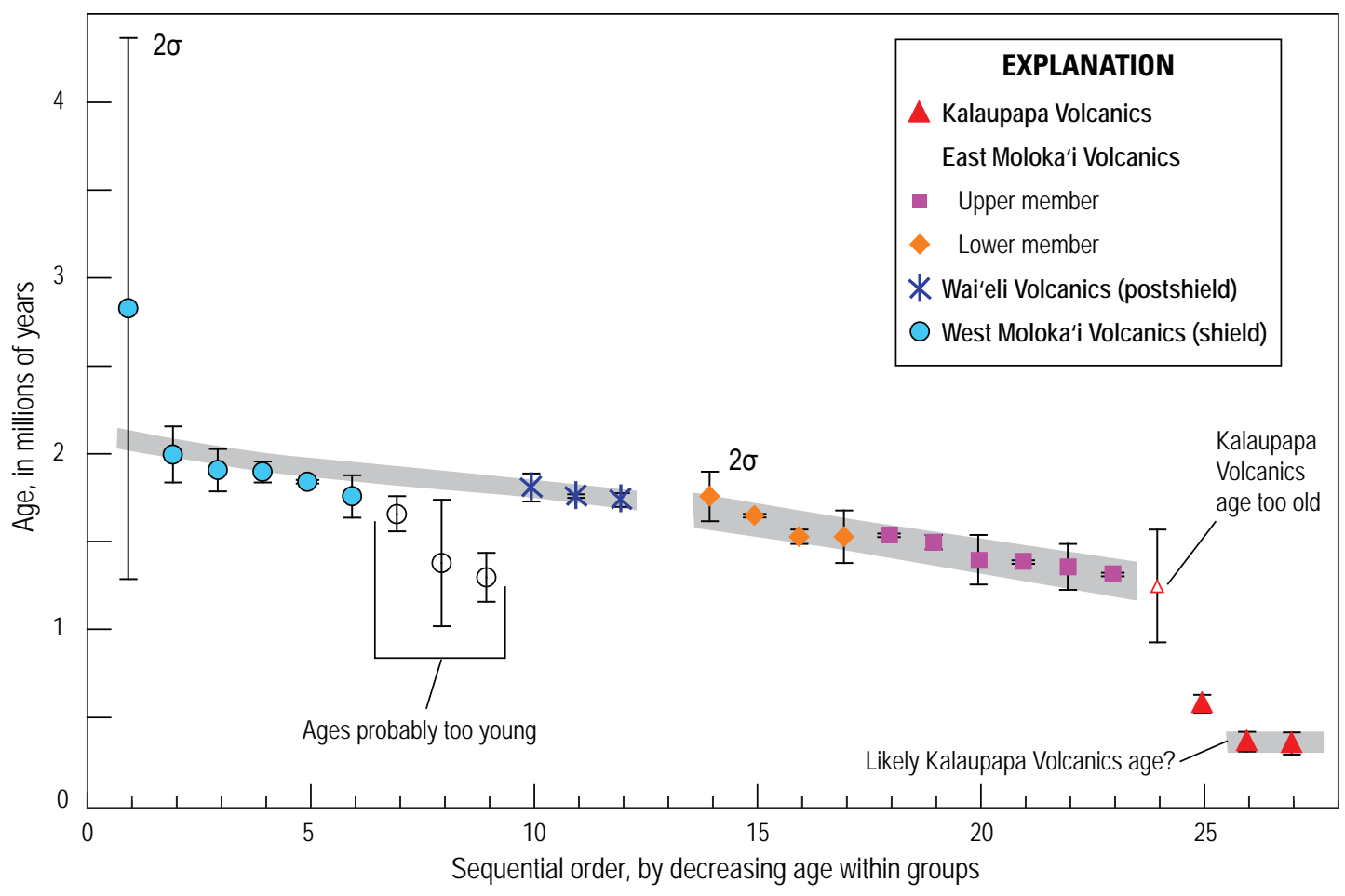

Figure 16. Radiometric ages from Moloka'i. Open symbols show ages likely too old (Kalaupapa Volcanics) or too young (West Moloka'i Volcanics). Gray bands show likely range of ages. Data from McDougall (1964), Naughton and others (1980), Clague and others (1982), Clague (1987a), and Sinton and others (2017). 
seen by us, so their depiction on our digital geologic map should be considered schematic. A recently discovered small submarine cone and associated lava flows lie about $15 \mathrm{~km}$ northeast of Kalaupapa (Clague and Moore, 2002). It, too, is likely part of rejuvenated-stage eruptions. Compositionally the Kalaupapa Volcanics ranges from tholeiitic basalt to basanite $\left(\mathrm{SiO}_{2}\right.$ ranges from 43.5 to 48 weight percent; fig. 15).

The hypothesis of a short-lived, monogenetic eruption is at odds with the radiometric dating, as acknowledged by Clague and Moore (2002). Three K-Ar ages range from about 0.57 to $0.34 \mathrm{Ma}$ (fig. 16). A preference toward the younger ages is indicated on figure 16 , but there is no statistical basis for discarding the $0.57-\mathrm{Ma}$ age. A substantially older age, about 1.24 Ma (Naughton and others, 1980) is too old, in light of only slightly older ages from the upper member of the East Moloka'i Volcanics.

Off the east shore of Moloka' $i$ is one other small vent that forms Mokuho'oniki and Kanahā islets (sheet 3). Interpreted by Stearns and Macdonald (1947) as part of the rejuvenated-stage sequence, it is shown separately on our map as the informally named tuff of Mokuho“oniki cone.

\section{Lāna'i}

\section{Setting and Stratigraphic Notes}

Lāna' $i$ is a one-volcano island, built up by shield-stage volcanic rocks assigned to the Lāna' $i$ Basalt stratigraphic unit (sheet 3; fig. 17). Rift zones radiating away from the summit to the northwest, southwest, and south have long been inferred on the basis of topography and dike concentrations (Stearns, 1940a). A partly infilled caldera about $5 \mathrm{~km}$ in diameter supposedly occupies the south-central part of the island, coincident with the topographic Pālāwai basin. Lāna'i became extinct while still in the shield stage of activity. All chemical analyses from Lāna'i are characteristic of shield-building volcanic rocks (fig. 18).

A large undersea landslide deposit, the Clark debris avalanche, can be traced back to the outer slope of Lāna' $i$ (bathymetric map, fig. 17; Eakins and others, 2003). Its upper limit of failure may be marked by the northwest-striking faults that nearly bisect the island (Moore and others, 1989). Indeed, if these faults are related to the Clark debris avalanche, then we might also question the caldera origin for the faults encircling the Pālāwai basin, which may have formed instead as a shallow sag when the island was weakly extended during Clark time. However, a 40-60-mGal Bouguer gravity anomaly centered over the Pālāwai basin suggests that a magma chamber, if not a caldera, may have been positioned in that area (fig. 17; Krivoy and Lane, 1965). The Clark debris avalanche is considered older than $0.65 \mathrm{Ma}$, on the basis of an estimated age for the deepest reef that originally grew on the shallow submarine shore of Lāna' $i$ during oxygen isotope stage 18 and has subsequently subsided (Moore and Campbell, 1987).

The Lāna' $i$ volcano is one of the lesser-studied volcanoes among the Hawaiian island chain. At this writing it has the fewest radiometric ages of any of the emergent volcanoes. Six samples collected by Bonhommet and others (1977) from around the southern third of the island yielded ages ranging from about 1.51
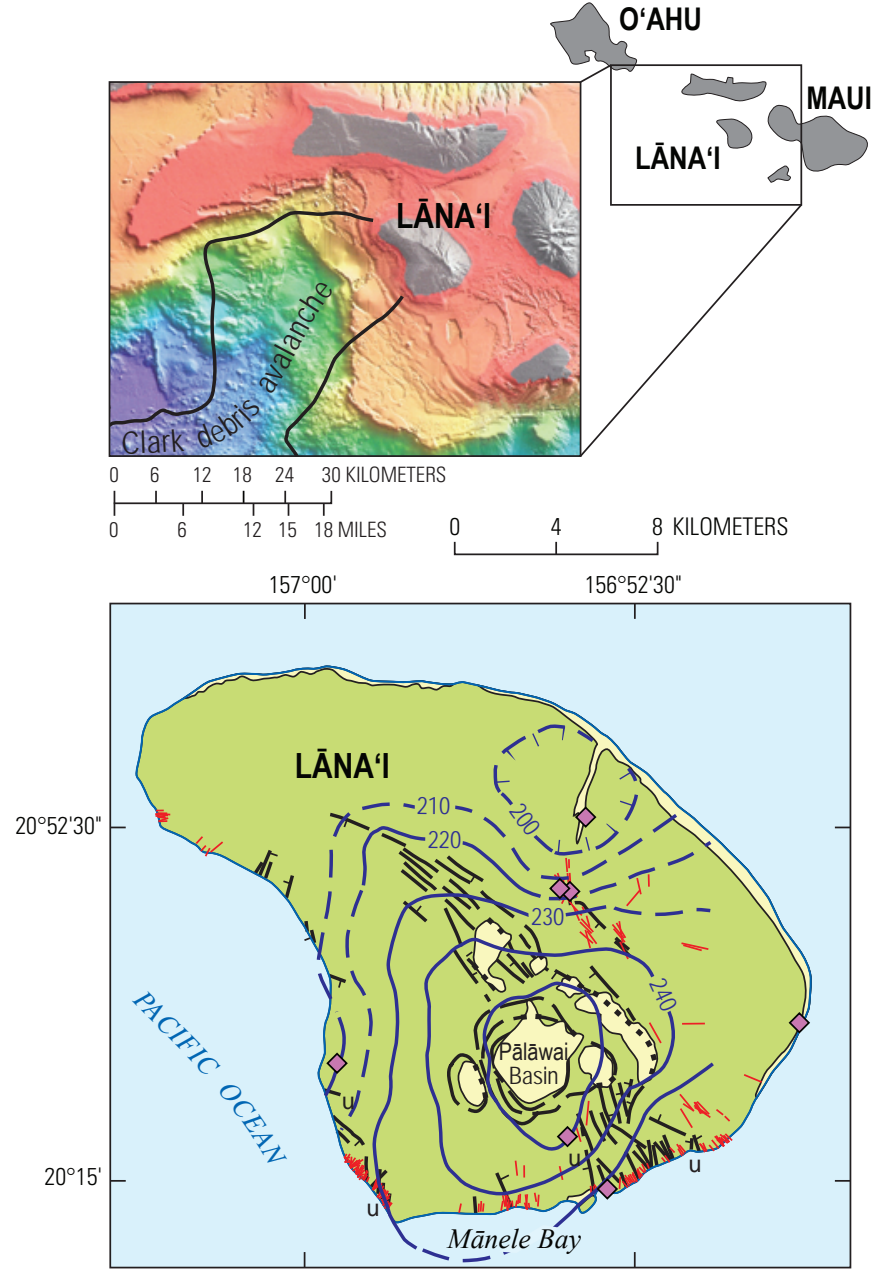

EXPLANATION

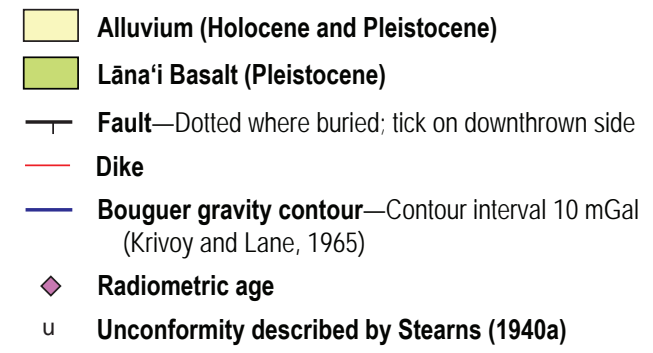

Figure 17. Geologic map of Lāna'i, generalized from this publication's digital map database. Geology from Stearns (1940a); gravity contours from Krivoy and Lane (1965). Bathymetric map (at top) from Eakins and others (2003). Clark debris avalanche outline from Moore and others (1989).

to $1.24 \mathrm{Ma}$ (fig. 19). No description was offered of the stratigraphic relations among the various sampled sites. As noted by Bonhommet and others (1977), the ages are indistinguishable at the 95-percent confidence level; therefore the ages were grouped to obtain a weighted mean age of $1.30 \pm 0.06 \mathrm{Ma}$. An alternative interpretation by isochron analysis yielded an age of $1.32 \pm 0.04 \mathrm{Ma}$, the age thought most representative of the top of the Lāna' $i$ volcanic shield (Bonhommet and others, 1977; recalculated by method of Dalrymple, 1979). Three other ages reported by Naughton and others (1980) had such large analytical error that they could correspond to eruptive events occurring anytime between 1.4 and $0.3 \mathrm{Ma}$. 
Figure 18. Alkali-silica $\left(\mathrm{Na}_{2} \mathrm{O}+\mathrm{K}_{2} \mathrm{O}\right.$ versus $\left.\mathrm{SiO}_{2}\right)$ diagram for analyzed rocks from Lāna'i. Grid fields labeled for those compositional types commonly recognized in Hawaiian islands; grid boundaries and Mauna LoaKîlauea data (small black $x$ and gray dot symbols) referenced in figure 2 caption. Lāna'i chemical data from West and others (1992, 21 analyses) and from Bonhommet and others (1977, 4 analyses).

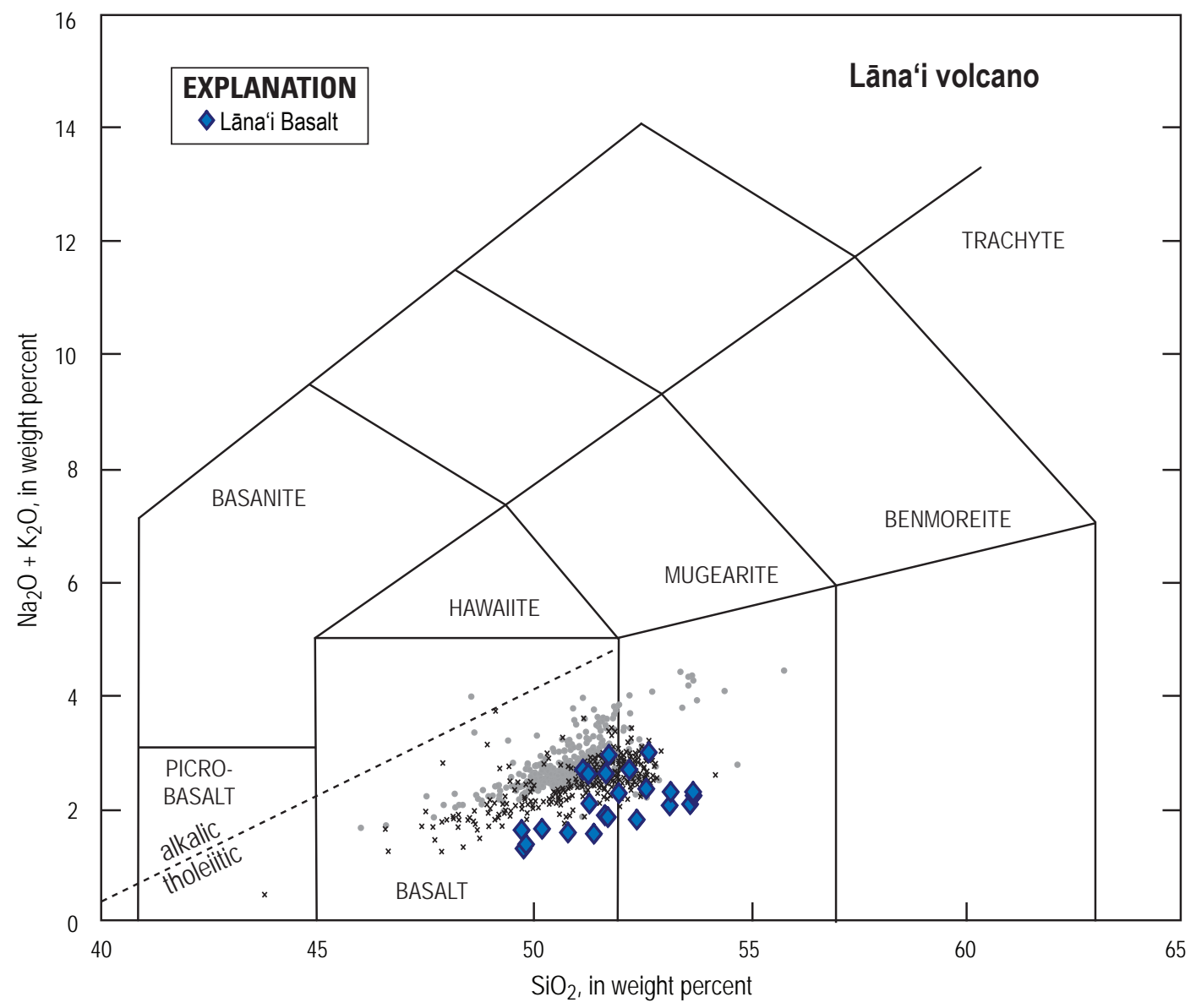

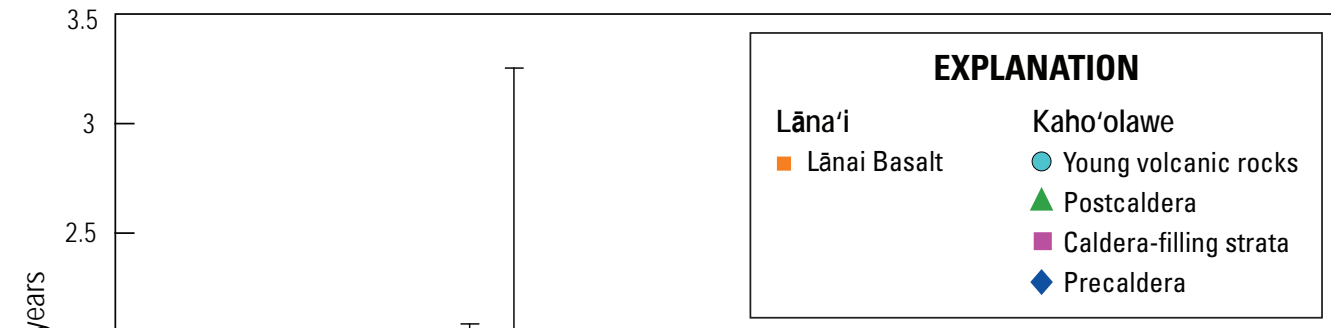

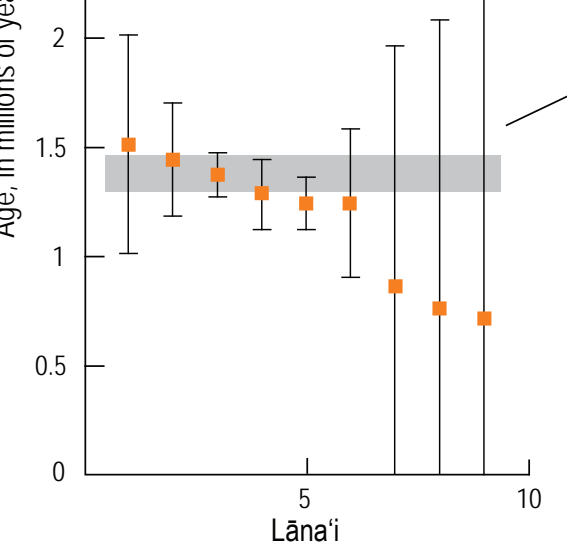

Lāna'i Basalt age if sampling is from narrow stratigraphic interval narrow stratigrap

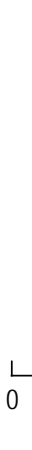

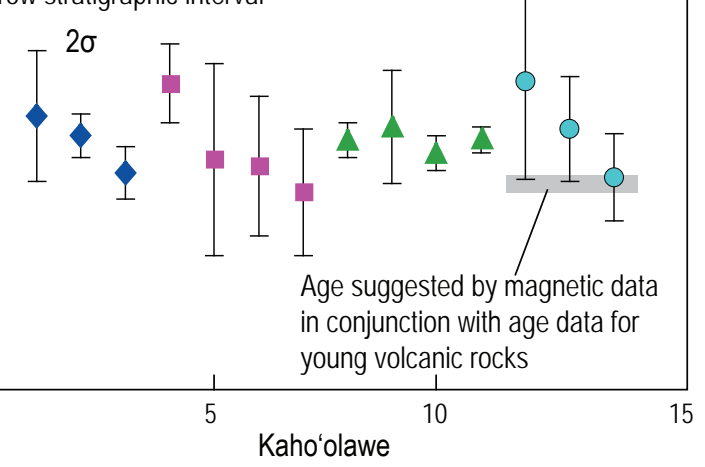

Figure 19. Radiometric ages from Lāna'i and Kaho'olawe. Gray bar across Lāna'i data shows age if sampling is from narrow stratigraphic interval, as suggested by Bonhommet and others (1977). For Kaho'olawe data, gray bar shows age range indicated by magnetic and age data. Data from Bonhommet and others (1977), Naughton and others (1980), Fodor and others (1992), and Sano and others (2006).

Sequential order, by decreasing age within groups

Stearns's original map was marked to indicate four sites where disconformities (erosional unconformities) were found in the stratigraphic sequence (Stearns, 1940a). The evidence in support of a disconformable relation was the interbedding of talus, hillwash colluvium, or mudflow deposits within the lava-flow sequence. It remains to be seen whether a dedicated effort to date the shield lava above and below the disconformities would yield ages that indicate a longer record of volcanism than is generally assigned to the top-of-shield stratigraphic sequence at Lāna'i. Reconnaissance paleomagnetic sampling found only 
reversed-polarity lava flows (Herrero-Bervera and others, 2000), but a more detailed study of a single 250 -m-thick sequence of lava flows suggests that as many as three normal-polarity subchronozones are present, corresponding to the Cobb Mountain, Jaramillo, and Kamikatsura Normal-Polarity Subchrons (HerreroBervera and Valet, 2003). If borne out (and details remain too vaguely reported to gauge), then Lāna'i volcanism may have continued until at least as recently as about $0.85 \mathrm{Ma}$.

Coarse calcareous breccia crops out at several localities on the south slope of Lāna'i (Stearns, 1940a). Today, most lies at altitudes lower than $70 \mathrm{~m}$, with isolated outcrops as high as about $170 \mathrm{~m}$. The deposits contain lava blocks, pebbles, and cobbles in a matrix of coral, coralline algae, and shells. As noted by Stearns (1940a), the lava clasts are chiefly angular to subangular. In addition there are calcite-filled veins at altitudes as high as about $375 \mathrm{~m}$. The origin of these deposits, perhaps the most accessible of the coralline breccia found on four islands, has been at the center of a controversy - either landslide-generated megatsunami or as storm beaches or uplifted shorelines — discussed in an earlier section entitled "Island Growth in Review."

\section{Kaho'olawe}

\section{Setting and Stratigraphic Notes}

Kaho'olawe is the smallest of the emergent volcanoes among the eight major islands. Its geologic history is known mainly from the early work by Harold Stearns (Stearns, 1940b). Subsequent studies have concentrated on geochemistry and radiometric ages of the island's lava flows.

The Kaho'olawe volcanic complex exposes the youngest part of shield-building strata, including a late-forming caldera and its infilling lava flows and thin tuff beds (sheet 3; fig. 20). Stearns (1940b) included the entire sequence and overlying postcaldera strata in a single stratigraphic unit, the Kanapou Volcanics. Geochemical analyses suggest that the postcaldera lava flows, which range from tholeiitic basalt to hawaiite, correspond to a transition into the postshield volcanic stage (fig. 21) (Fodor and others, 1992; Leeman and others, 1994).

According to Langenheim and Clague (1987), the lava of Kaho‘olawe volcano was erupted along a prominent rift zone trending west-southwest (azimuth 245). Stearns (1940b) made clear that the southwest rift zone was an assumption drawn from analogy with other Hawaiian volcanoes. No cliffs run transverse to the rift zone, so only a few of its dikes are exposed (Stearns, 1940b). Three cones lie along the zone. An east rift zone was presumed to extend eastward from the island's summit, on the basis of a dike swarm exposed along the northern part of Kanapou Bay (Stearns, 1940b). Stearns also suspected that a rift zone trended northward, an observation that thereby explained the slight topographic elongation of the island in that direction.

Geologic map data for Kaho‘olawe have always been sparse, mainly because the U.S. Navy condemned the island to a bombing range in the 1940s. Even now that the island has been partially cleaned of ordinance and control has been returned to the State, the hazard of unexploded ordnance creates nearly insurmountable obstacles for free-ranging map traverses. Stearns’ published geologic map was a generalized, small-scale $(1: 130,000)$, page-size figure appearing in the Kaho'olawe monograph (Stearns, 1940b, his fig. 25). Indeed, among the major islands portrayed geologically in the Hawai' $i$ Hydrography series, only Kaho“olawe lacked a depiction on a separate map plate at 1:62,500 scale. We obtained a copy of Stearns's hand-drafted, prepublication 1:62,500 portrayal of Kaho'olawe's geology to use for digitizing this map, courtesy of M.O. Garcia (written commun., 2003). This map showed Stearns' preliminary depiction of an approximate separation between shield-stage and late-shield or postshield lava on Kaho'olawe, which we have incorporated on our map (sheet 3; fig. 20). The contact also appeared as part of a previously published sketch geologic map (Leeman and others, 1994).

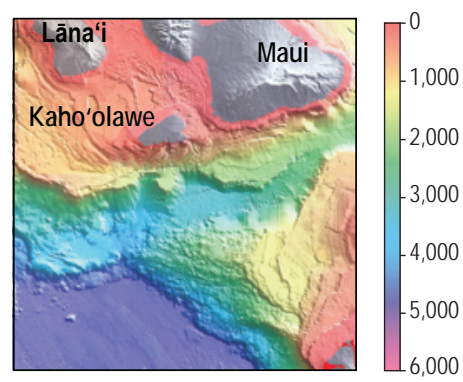

EXPLANATION Depth scale, in meters

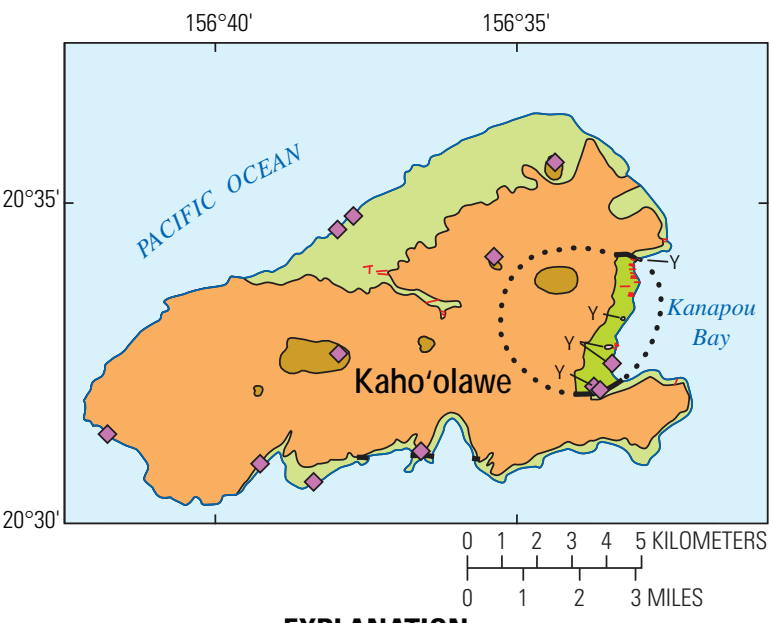

EXPLANATION

Young volcanic rocks (Pleistocene)-Some outcrops marked by "Y" where too small to show

Kanapou Volcanics (Pleistocene)

Vent deposits

Late-shield or postshield lava flows Caldera-filling strata—Chiefly lava flows

Precaldera lava flows

- Fault-Dotted where buried or flooded

- Dike

$\diamond$ Radiometric age sample location

Figure 20. Geologic map of Kaho'olawe, generalized from this publication's digital map database. Geology chiefly from Stearns (1940b) and a manuscript map (H.T. Stearns, unpub. data). Bathymetric map (at top) from Eakins and others (2003). 
Mapped separately from the Kanapou Volcanics are the deposits of a final volcanic episode, preceded by the slope collapse that carved out Kanapou Bay (Stearns, 1940b). Alluvial deposits accumulated on the west wall of Kanapou Bay after the collapse. Dikes then cut through the alluvial deposits at five(?) locations, erupting cinders and sparse lava flows that mantle the alluvial deposits. These dikes, cinders, and lava flows are tholeiitic in composition where sampled from two sites at the south end of Kanapou Bay (fig. 21; Fodor and others, 1992).

Overall, the radiometric ages indicate an age of about 1.25 Ma for the shield-forming lava flows (fig. 19). The individual ages are difficult to reconcile internally and probably suffer from the problems characteristic in dating the older Hawaiian shield volcanoes, namely low potassium content among tholeiitic rocks and weathering and mobility of potassium and argon in some samples (Fodor and others, 1992). For example, a lava flow collected near the top of the shield-stage Kanapou strata directly beneath a thick late-shield or postshield lava has an age of 1.25 $\pm 0.14 \mathrm{Ma}$ (Fodor and others, 1992). Another sample was assigned to the shield stage by Fodor and others (1992), apparently on the basis of its age, 1.40 \pm 0.09 Ma. However, according to Stearns’s unpublished mapping, the 1.40-Ma sample is part of the postcaldera suite, hence possibly of postshield stratigraphic position. These two ages were combined by Fodor and colleagues to suggest an average age for the shield of $1.34 \pm 0.08 \mathrm{Ma}$, but only the 1.25-Ma age may be pertinent if Stearns's mapping is correct. Two other ages from precaldera shield strata were viewed skeptically by Fodor and colleagues: an age of $0.99 \pm 0.06 \mathrm{Ma}$ from precaldera shield tholeiite and an age of $1.08 \pm 0.04 \mathrm{Ma}$ from the Keālialuna vent, which Stearns considered also of precaldera stratigraphic position. The ages seem too young in view of ages from possible postshield strata.

Several "postshield" lava ages range from about 1.20 to 1.14 Ma (Naughton and others, 1980; Fodor and others, 1992). These lava flows, chiefly alkali basalt, tend to be fresher and have higher potassium content, so their ages may be more accurate than those from the shield-stage lava flows. Two other ages, each about $1 \mathrm{Ma}$ and presumably from postshield strata, were collected by H.S. Palmer in 1925 and dated in the 1970s (Naughton and others, 1980; their "upper member" of Kaho'olawe volcanic strata). The published site descriptions are inadequate to determine stratigraphic setting, although one sample is from a thick platy flow that likely is of postcaldera emplacement age. The analytical error reported for these two samples is sufficiently large that they overlap other postcaldera ages (fig. 19). Thus, broadly viewed, postshield volcanism might have been active from about 1.2 to $1.1 \mathrm{Ma}$.

As part of this map project, we collected three samples for dating the youngest volcanic deposits, those that drape the wall of Kanapou Bay. The southerly cinders and lava are from a dike with normal-polarity magnetization, as measured in the field with a portable fluxgate magnetometer. The other sample is from a dike found $0.8 \mathrm{~km}$ north along the coast; its polarity was indeterminate owing to surprisingly weak magnetization. Both produced $\mathrm{K}-\mathrm{Ar}$ ages of about $1 \mathrm{Ma}$, which, in conjunction with the magnetization, suggests emplacement during the Jaramillo Normal-Polarity Subchron, about $0.98 \mathrm{Ma}$ (Sano and others, 2006). The implication is
Figure 21. Alkali-silica $\left(\mathrm{Na}_{2} \mathrm{O}+\mathrm{K}_{2} \mathrm{O}\right.$ versus $\left.\mathrm{SiO}_{2}\right)$ diagram for analyzed rocks from Kaho'olawe. Grid fields labeled for those commonly used in Hawaiian islands; grid boundaries and Mauna LoaKīlauea data (small black $\mathrm{x}$ and gray dot symbols) referenced in figure 2 caption. Kaho'olawe chemical data from Fodor and others (1992, 43 analyses), Leeman and others (1994, 13 analyses), Washington (1923, 1 analysis), Rudek and others (1992, 1 analysis), and Fodor and others (1993, 1 analysis).

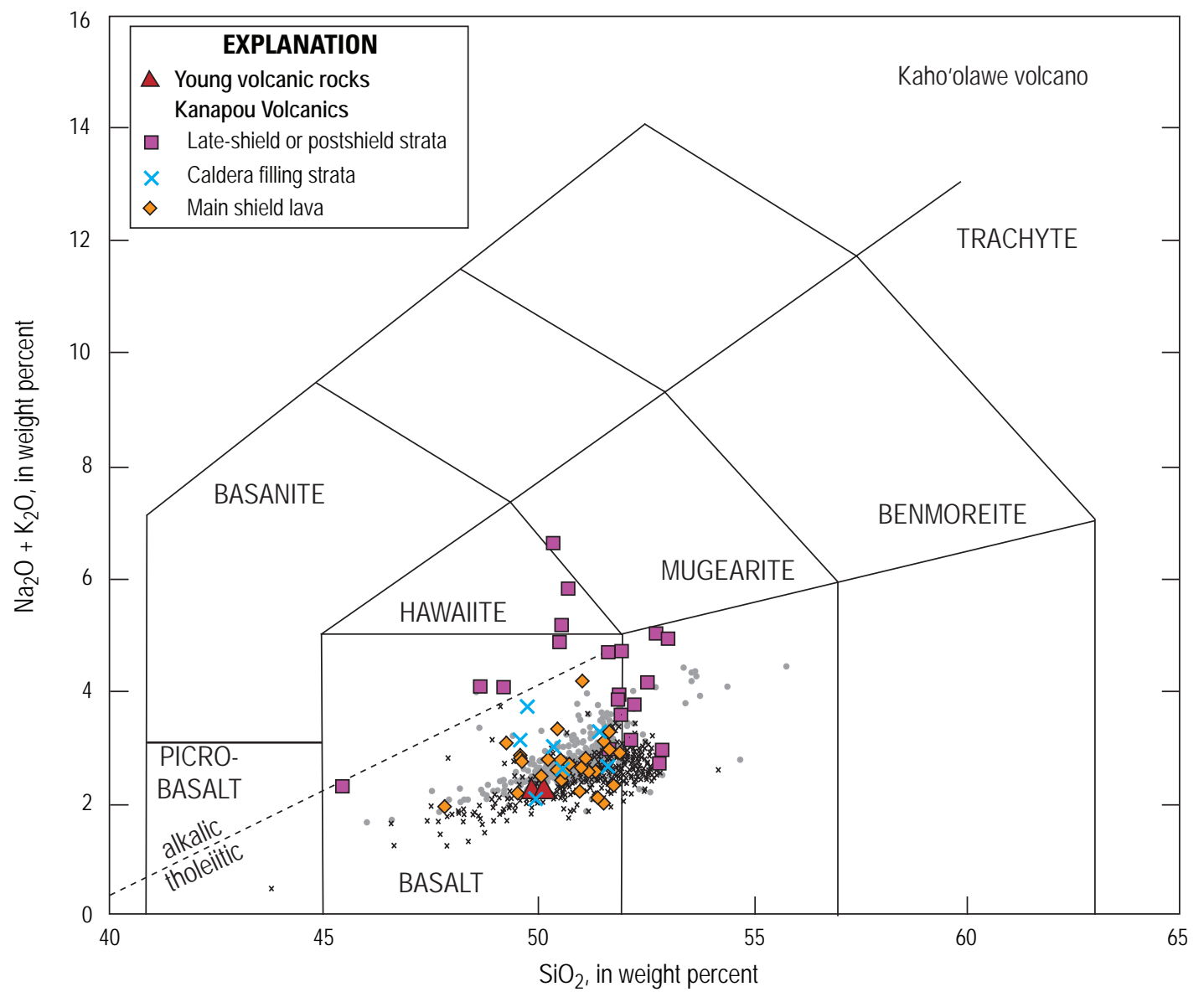


that the steep slopes of Kanapou Bay formed during Kanapou time as the volcano was ending its postshield activity, another example of how volcanic deposits in a post-erosional physiographic setting needn't be evidence for rejuvenated stage volcanism. The island has not had any volcanic activity in roughly 1 million years.

\section{Maui}

Maui is a two-volcano island. By one interpretation, its nickname, the "Valley Isle," originates from the broad lowland that lies between West Maui volcano and, to the east, Haleakalā volcano. Equally likely, the nickname is in reference to the valleys of Nā Wai'ehā (the Four Waters), a poetic name for Wailuku, Waiehu, Waihe‘e, and Waikapū.

\section{West Maui Volcano}

The relation between stratigraphic units and interpreted volcanic stages is so clearcut on West Maui that it formed the basis for the example we used in this explanatory text in the section "Island Growth in Review." West Maui's oldest strata are assigned to the Wailuku Basalt (sheet 4; fig. 22). A caldera-filling sequence and dike complex are mapped separately within the Wailuku Basalt. The caldera sequence, defining a roughly circular area about $3 \mathrm{~km}$ across, coincides approximately with the southern half of the 'Iao Valley headwall amphitheater. Rift zones that trend northward and south-southeastward from the volcano's central area are delineated on the basis of mapped dike complexes, other dikes mapped separately, and the topographic elongation of the volcano (Stearns and Macdonald, 1942). Other dike orientations and vent concentrations have led to proposals for additional minor rift zones oriented southwest and northeast, but those trends lack gravity or topographic expressions (Diller, 1981; Macdonald and others, 1983). Judging from the published record, West Maui has the greatest number of mappable stocks, plugs, and sills in its shield-stage unit (Stearns and Macdonald, 1942); on the other islands, most intrusions are dikes.

The Honolua Volcanics stratigraphic unit overlies the Wailuku Basalt, and it forms a thin cap of benmoreite and trachyte lava flows and domes (fig. 23). The Honolua Volcanics are found chiefly on the volcano's northern and southern flanks, but a few domes form prominent hills on the west flank. Honolua rocks tend to weather light to very light gray. Seen from Kahului, the light-colored cliffs along the northeast shore of West Maui are built of the benmoreite and trachyte of the Honolua Volcanics.

Radiometric ages from the Wailuku Basalt range from about 2 to $1.3 \mathrm{Ma}$, and those from the Honolua Volcanics range from 1.3 to 1.1 Ma (fig. 24; McDougall, 1964; Naughton and others, 1980; Sherrod and others, 2007a). Although the figure 24 depiction shows some Wailuku ages younger than, and some Honolua ages older than, 1.3 Ma, the 1.3-Ma transition considers stratigraphic position (Honolua lava always overlies Wailuku strata) and the analytical error of the ages. The overlap of ages at about 1.3 Ma suggests that very little time elapsed between the switchover from latest shieldstage eruptions to those of the postshield stage. No field-based evidence of interfingering is known, so the shield stage might be thought of as ending abruptly, geologically speaking, before the onset of postshield-stage volcanism.
Four cinder and spatter cones, two of which issued lava flows, represent rejuvenated-stage volcanism on West Maui. These deposits are named the Lahaina Volcanics for the town where the most extensive of the lava flows is exposed. All are broadly basanitic. Two eruptions occurred about $0.6 \mathrm{Ma}$ and two others about 0.3 Ma (Tagami and others, 2003). Chemical analyses indicate some compositional diversity within each of the two Lahaina eruptive episodes.

West Maui is flanked on its southwest and east sides by alluvial fans substantially older than those now being deposited by modern streams (fig. 22). West Maui has the third-greatest expanse of older alluvium of the Hawaiian volcanoes, $57 \mathrm{~km}^{2}$, and more extensive deposits are found only on Wai'anae and Ko'olau volcanoes, Island of $\mathrm{O}^{`}$ ahu (153 and $102 \mathrm{~km}^{2}$, respectively). One of West Maui's older fans underlies the Olowalu lava flow of the Lahaina Volcanics, emplaced about 0.61 Ma (Tagami and others, 2003), the only place on West Maui where a limiting minimum age has been ascertained for at least part of the older alluvium.

\section{Haleakalā Volcano}

East Maui volcano, better known today as Haleakalā, is one of the largest volcanoes in the island chain (Robinson and Eakins, 2006). It also is the only volcano beyond the Island of Hawai' $i$ that is considered potentially active, having erupted frequently during Holocene time and as recently as about A.D. 1600 (Sherrod and others, 2006).

The oldest exposed lava flows on Haleakalā are tholeiitic and alkalic basalt of the Honomanū Basalt (fig. 25). The Honomanū Basalt was considered part of the shield-building stage by Stearns and Macdonald (1942), and chemical analyses show that its lava flows are typical of those occurring in the late shield or transitional stages of several Hawaiian volcanoes, where lava compositions become increasingly alkalic. Ages from the Honomanū Basalt range from about 1.1 to $0.97 \mathrm{Ma}$ (fig. 26) (Chen and others, 1991).

A substantial episode of postshield volcanism is represented by the Kula and the Hāna Volcanics (Stearns and Macdonald, 1942). The Kula thickly mantles most of Haleakalā. It is more than $1 \mathrm{~km}$ thick at the summit of the volcano, where it forms the walls of Haleakalā Crater. Kula volcanism must have begun almost immediately at the close of Honomanū time, because the oldest dated Kula lava flow has an age of $0.93 \pm 0.33 \mathrm{Ma}$ (Chen and others, 1991), and several other ages are only slightly younger (fig. 26). Rocks of the Kula Volcanics around the rim of Haleakalā Crater have produced ages as young as about $0.15 \mathrm{Ma}$ (Sherrod and others, 2003).

The Kula Volcanics are chiefly 'a'ā lava flows, in contrast to the predominantly pāhoehoe lava in the Honomanū Basalt. Near the volcano's summit, pāhoehoe is exposed low in the walls of Haleakalā Crater, at a stratigraphic position near the base of the Kula Volcanics. Its stratigraphic setting and lithologic character led Stearns and Macdonald (1942) to assign the pāhoehoe lava flows to the Honomanū Basalt. Subsequent geochemical analyses lent doubt to this correlation, owing to their higher total alkali content, and for a short time the pāhoehoe was assigned to a newly named Kumu'iliahi Formation (Macdonald, 1978). Since the 1980s, these same strata have been considered part of the 

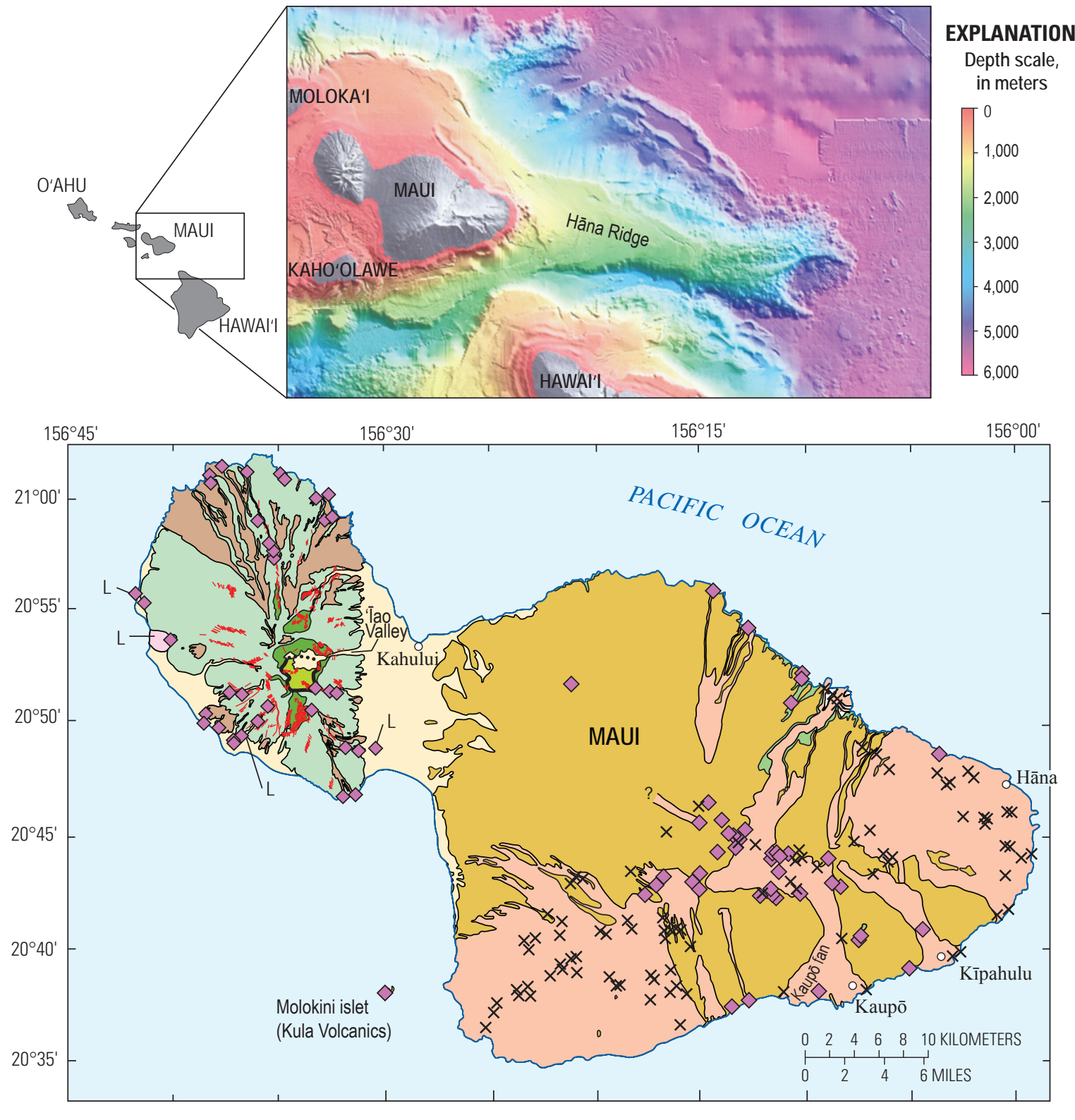

EXPLANATION

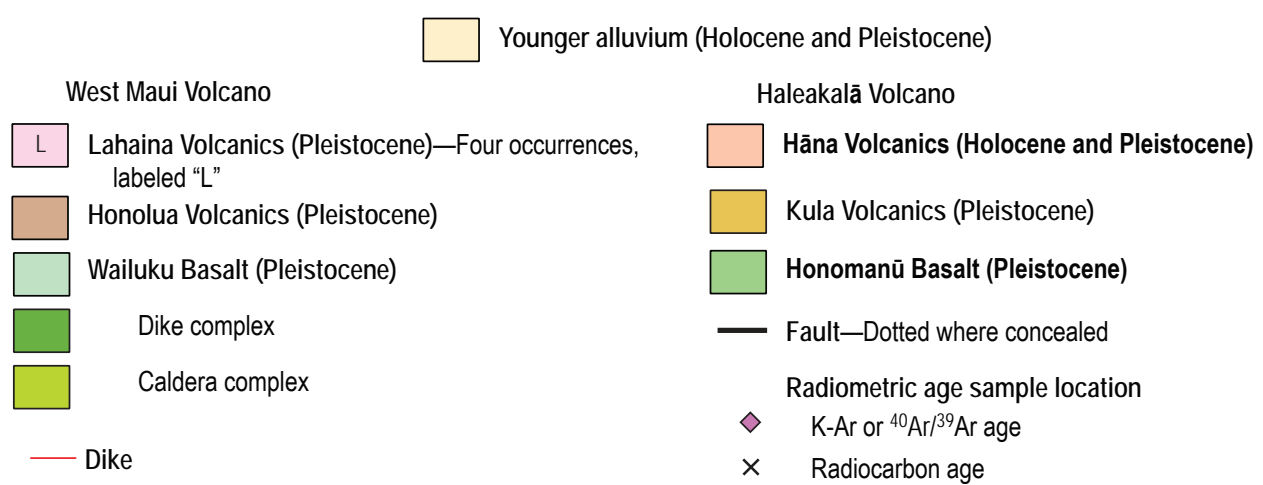

Figure 22. Geologic map of Maui, generalized from this publication's digital map database. Geology from Stearns and Macdonald (1942) and D.R. Sherrod (this map). Bathymetric map (at top) from Eakins and others (2003).

Kula Volcanics because of their alkalic character (Macdonald and others, 1983; Langenheim and Clague, 1987), a convention we followed as part of our mapping.

A thick sequence of debris-flow deposits is exposed on the volcano's south flank. Its stratigraphic name, the Kaupō Mud Flow, is anachronistic, given the advances in understanding how such poorly sorted deposits come to be emplaced; but we avoid changing the name in this publication, a task better left for a more detailed investigation of East Maui geology. The Kaupō Mud Flow unit is older than $0.12 \mathrm{Ma}$ on the basis of a K-Ar age from a lava in the overlying Hāna Volcanics, described herein (Sherrod and others, 2003). 


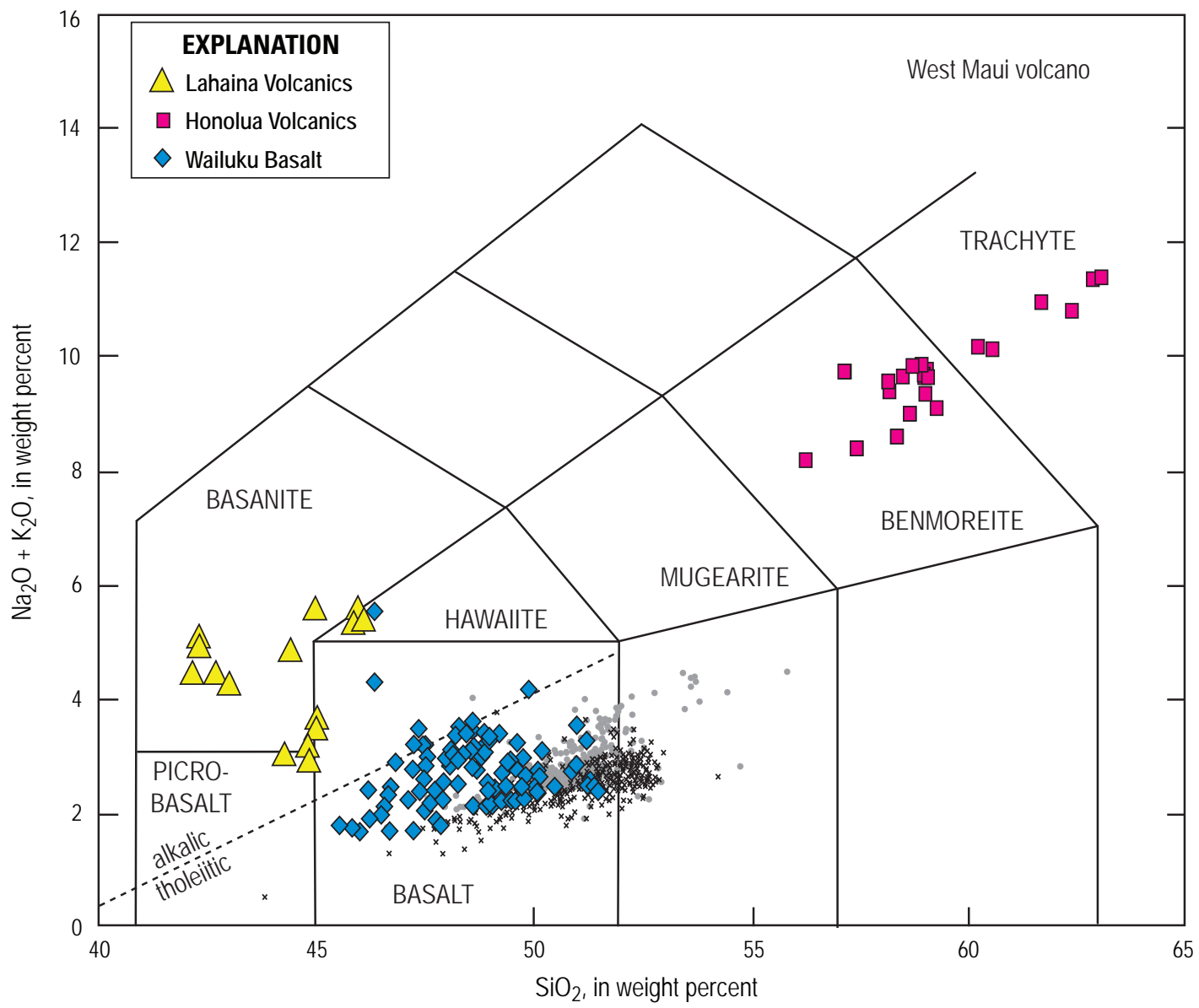

Figure 23. Alkali-silica $\left(\mathrm{Na}_{2} \mathrm{O}+\mathrm{K}_{2} \mathrm{O}\right.$ versus $\left.\mathrm{SiO}_{2}\right)$ diagram for analyzed rocks from West Maui. Grid fields labeled for those commonly used in Hawaiian islands; grid boundaries and Mauna Loa-Kīlauea data (small black $x$ and gray dot symbols) referenced in figure 2 caption. West Maui chemical data from Sherrod and others (2007a, 31 analyses), Diller (1982, 30 analyses), Gaffney and others (2004, 29 analyses), Macdonald and Katsura (1964, 18 analyses), Tagami and others (2003, 10 analyses), Macdonald (1968, 7 analyses), Sinton and others (1987, 4 analyses), and Sinton and Rowland (1997, 2 analyses).

Figure 24. Radiometric ages from West Maui volcano. Gray band shows likely range of ages across the suite. One Lahaina age considered much too old, compared to four other more precisely dated lava flows. Data from McDougall (1964), Naughton and others (1980), Tagami and others (2003), and Sherrod and others (2007a).

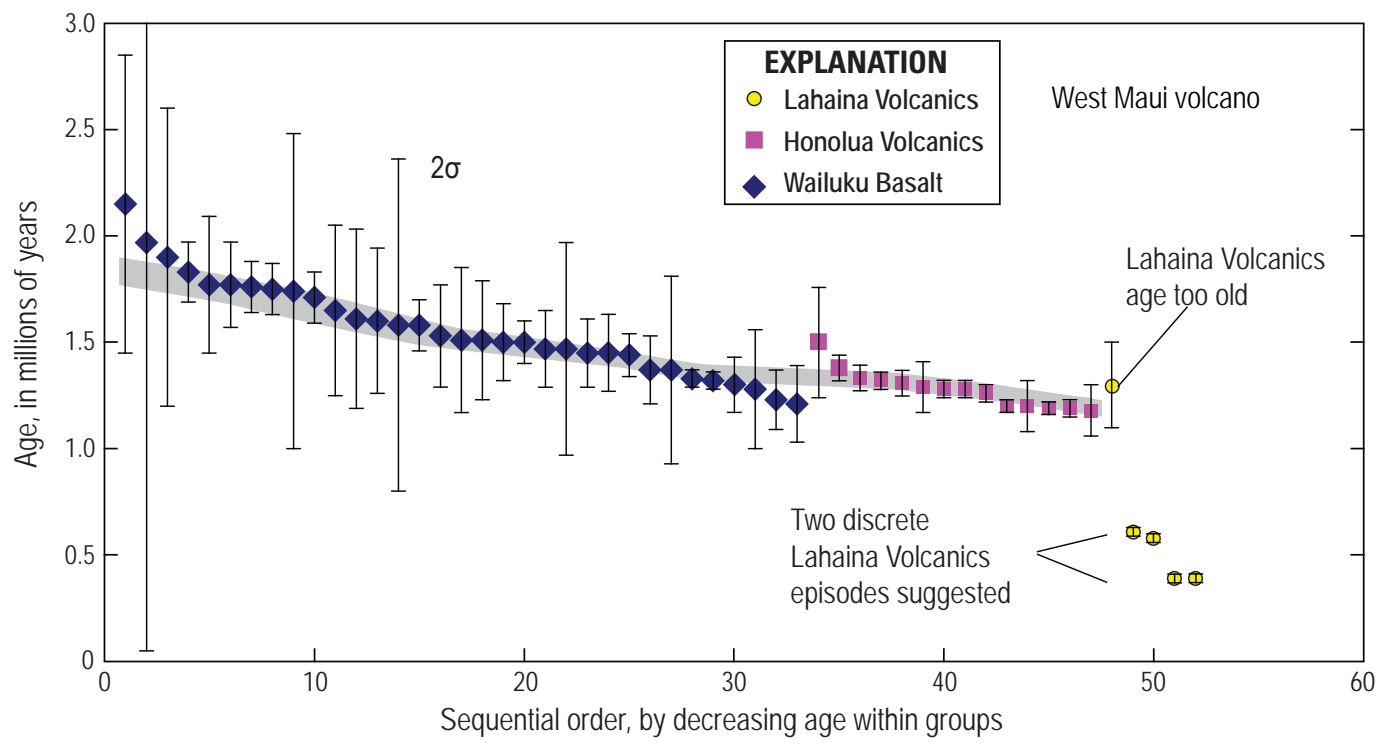

Young lava flows on Haleakalā, assigned to the Hāna Volcanics, issued from the same rift zones that produced the Kula Volcanics. Recent mapping and new radiocarbon and K-Ar ages have allowed a fairly detailed depiction, by age grouping, of lava-flow units within the Hāna Volcanics (fig. 27). The groupings are incorporated into the digital database for this geologic map, as are many informal flow-unit names, some of which are shown on figure 27. We abandon the term Kīpahulu Member, which designated a part of the Hāna Volcanics on the southeast side of East Maui (Stearns and Macdonald, 1942; Langenheim and Clague, 1987). Our mapping and dating find that these lava flows range widely in age and lithology, including ankaramitic lava flows erupted from a cinder cone at the mouth of Kippahulu Valley about 25,000 yr ago (Sherrod and others, 2006) and aphyric bench-capping lava flows that filled an ancestral Kippahulu Valley as early as $0.12 \mathrm{Ma}$ (Sherrod and others, 2003). These latter units are depicted as informally named sequences within the Hāna Volcanics on our map. 


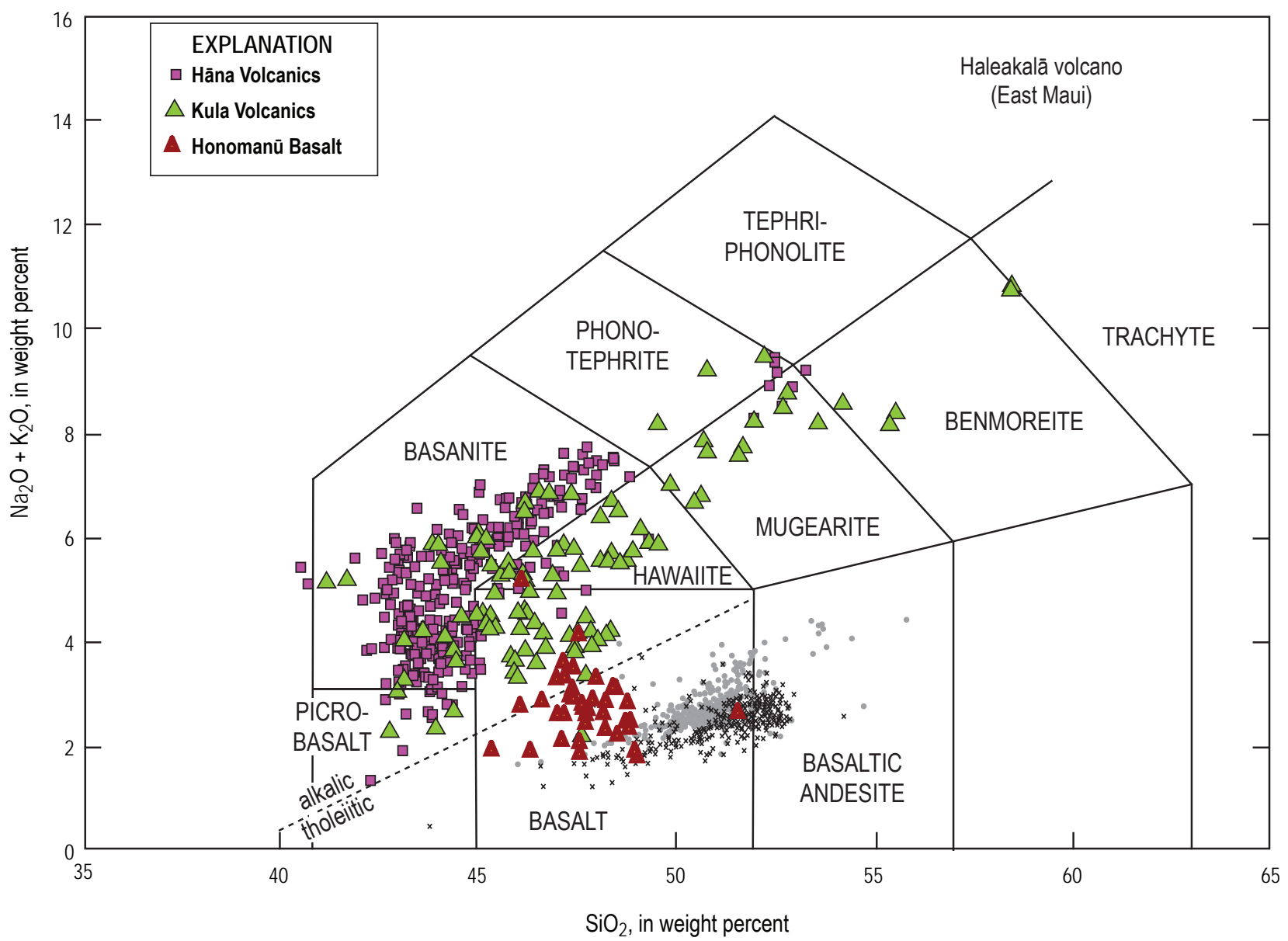

Figure 25. Alkali-silica $\left(\mathrm{Na}_{2} \mathrm{O}+\mathrm{K}_{2} \mathrm{O}\right.$ versus $\left.\mathrm{SiO}_{2}\right)$ diagram for analyzed rocks from Haleakalā volcano, East Maui. Grid boundaries and Mauna Loa-Kïlauea data (small black $x$ and gray dot symbols) referenced in figure 2 caption. Haleakalā chemical data from D.R. Sherrod (unpub. data, 184 analyses), Bergmanis (1998; with many appearing in Bergmanis and others, 2000; 99 analyses), Sherrod and others (2003, 52 analyses), West and Leeman (1994, 43 analyses), West (1988, 31 analyses), Chen and Frey (1985) and Chen and others (1990) (together, 29 analyses), Chen and others (1991, 23 analyses), Macdonald (1968, 16 analyses), Macdonald and Powers (1968, 15 analyses), Macdonald and Katsura (1964, 8 analyses), Brill (1975, 8 analyses), Macdonald and Powers (1946, 6 analyses), and Horton (1977, 6 analyses).

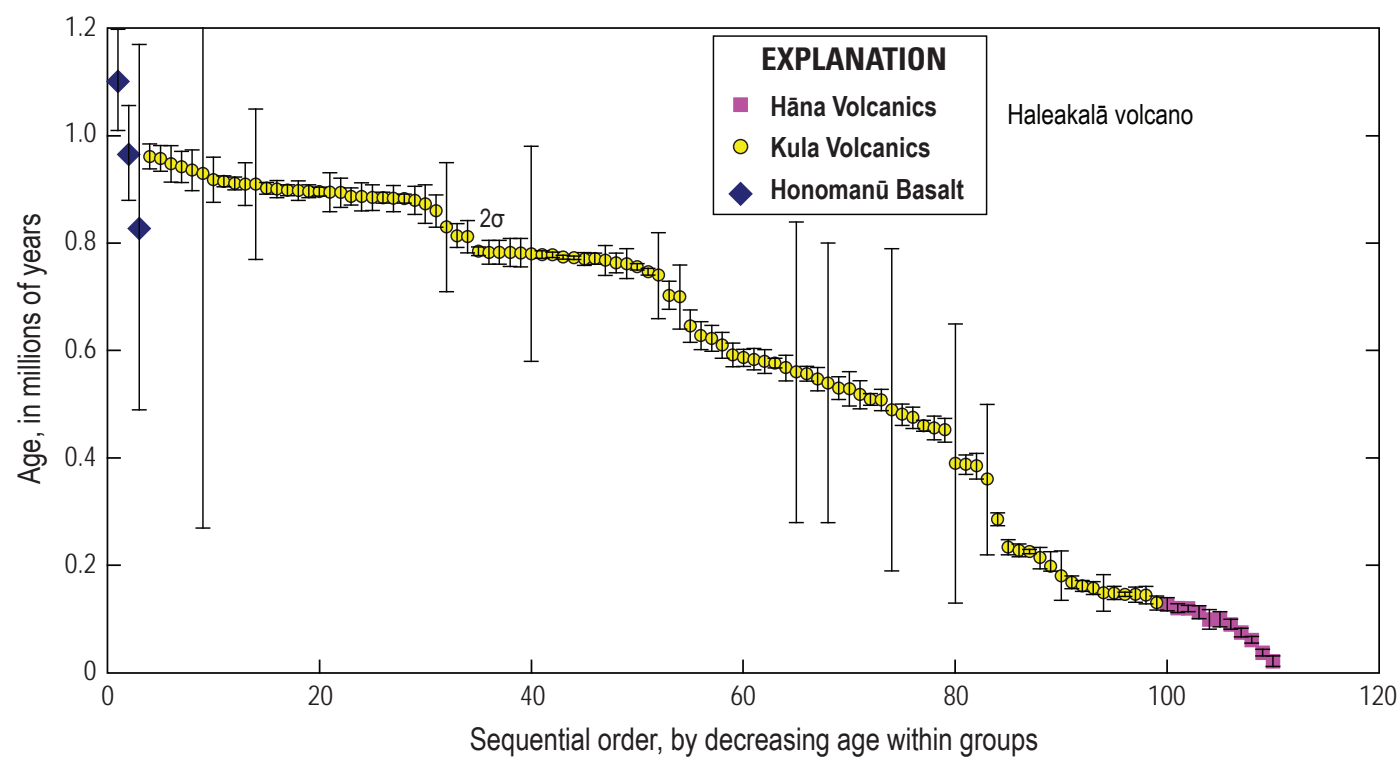

Figure 26. Radiometric ages from Haleakalā volcano. Data from McDougall (1964), Naughton and others (1980), Chen and others (1991), Baksi and others (1992), Singer and Pringle (1996), Singer and others (1999), Sherrod and others (2003), Coe and others (2004), and Kirch and others (2004). An additional 75 radiocarbon ages spanning the last 50,000 years are summarized in Sherrod and others (2006). 
The lava flows of the Hāna were thought to have been emplaced following a lengthy period of erosion, which led to their interpretation previously as rejuvenated-stage deposits. Radiometric dating, however, shows that the gap in ages between Kula and Hāna lava flows is small, only about 0.03 m.y. This brevity, and the geochemical similarity between Hāna and underlying Kula lava, indicates that the Hāna Volcanics unit marks the waning of postshield-stage volcanism, not a separate rejuvenated stage (Sherrod and others, 2003). Thus, the postshield volcanic strata of Haleakalā include both the Kula and Hāna Volcanics, whose combined ages span more than 900,000 years. This postshield longevity, more than three times that of any other Hawaiian volcano, is the most lengthy in the island chain. The reason for prolonged postshield activity at Haleakalā is still speculative. One idea relates the prolonged activity to the volume of lava produced during the shield stage, which may be a crude proxy for the amount of heat emplaced into the base of the lithosphere during a particular volcano's shield stage (Sherrod and others, 2003).

Though its volcanic vigor has lessened, Haleakalā has continued to erupt every 200 to 500 years (Bergmanis and others, 2000; Sherrod and others, 2006). It is the only volcano in the Hawaiian group besides those on the Island of Hawai' $i$ to show any recent activity. Its youngest lava, once thought as young as A.D. 1750-1790 (Stearns and Macdonald, 1942; Oostdam, 1965), is now thought to have formed between A.D. 1449 and 1633 , on the basis of calibrated radiocarbon ages from two sites (Sherrod and others, 2006).

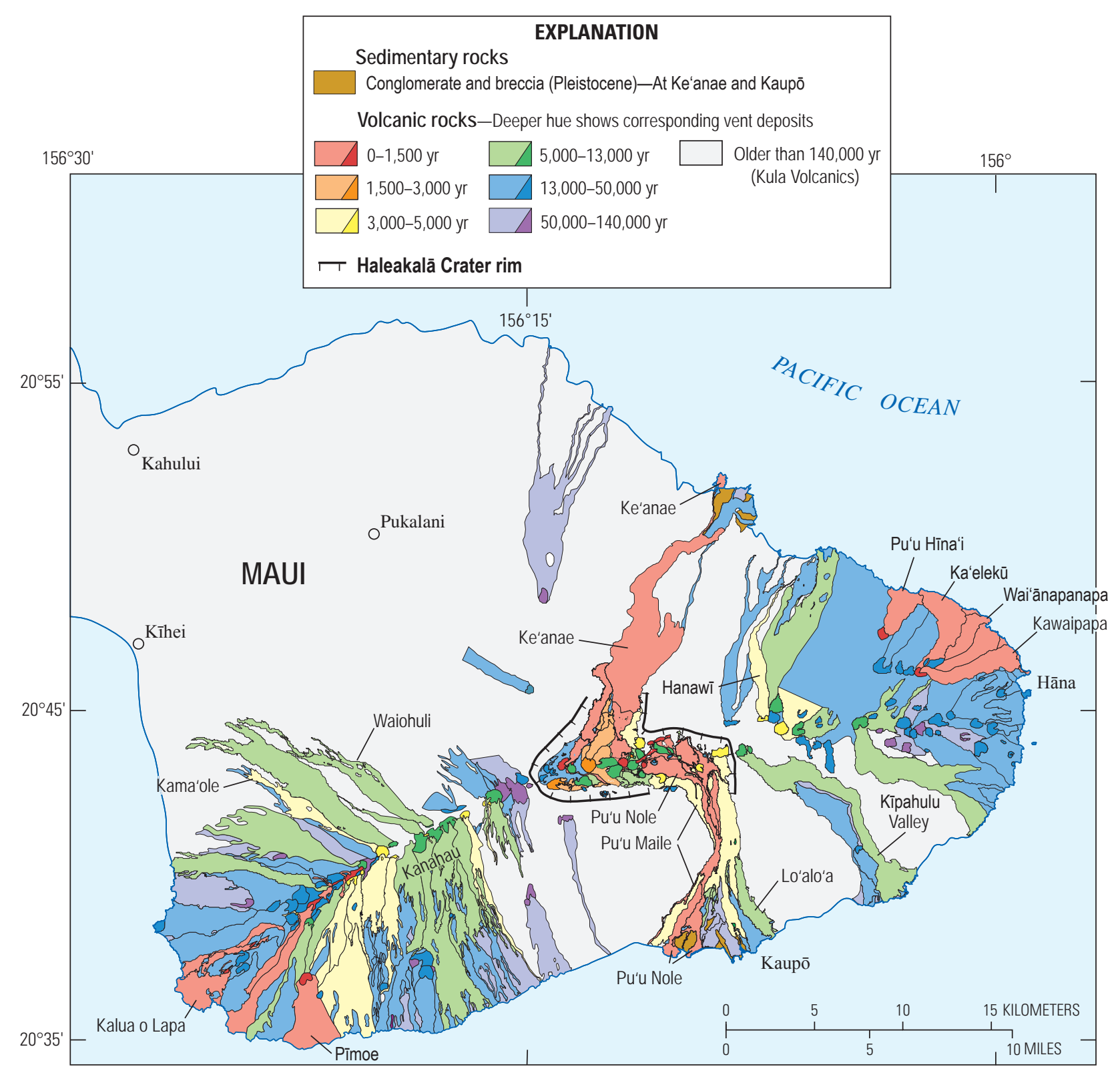

Figure 27. Map showing strata of the Hāna Volcanics, on Maui, by age (from Sherrod and others, 2006). Labeled are some informally named units. 


\section{Hawai'i}

Youngest of the islands in the Hawaiian archipelago, the Island of Hawai' $i$ encompasses five major shield volcanoes. A sixth volcano, Māhukona, lies flooded offshore north of KailuaKona (fig. 28). A seventh volcano, Lō'ihi, is the newest in the chain, albeit still lying $980 \mathrm{~m}$ beneath the sea. For an excellent synopsis of volcano growth and evolution, both conceptually for the island chain and specifically for the Island of Hawai' $i$, see Moore and Clague (1992).

\section{Kohala}

Kohala is the oldest of the volcanoes on the Island of Hawai'i. Its exposed lava flows are all younger than $0.78 \mathrm{Ma}$. Given growth rates of shield-stage volcanoes and rate for lithospheric plate transport above the Hawaiian hot spot, it is likely that the oldest parts of Kohala, now buried and below sea level, are as old as about $1 \mathrm{Ma}$, an estimate substantiated by newly obtained ages from offshore, discussed next.
Kohala has an axial rift zone that was active in both shield and postshield time. The trace of the southeast rift zone passes beneath Mauna Kea. By modern interpretations, it reappears farther southeast as the submarine Hilo Ridge, on the basis of correlation of submarine terraces between the ridge and Kohala's slopes and isotopic similarity of ridge samples and Kohala lava (see Holcomb and others, 2000). Also, the gravity expression of the Hilo Ridge aligns more directly with the trend of the gravity field coincident with Kohala (Kauahikaua and others, 2000) than with that of neighboring Mauna Kea, of which Hilo Ridge was once thought a part (Fiske and Jackson, 1972; Macdonald and others, 1983; Moore and Clague, 1992). The Hilo Ridge has bulk magnetic character that indicates it is built chiefly by reversedpolarity volcanic rocks, evidence that much of the ridge is older than $0.78 \mathrm{Ma}$ (Naka and others, 2002). Ages from pillow basalt clasts $\left({ }^{40} \mathrm{Ar} /{ }^{39} \mathrm{Ar}\right)$ collected from the distal toe of the Hilo Ridge are about 1.2-1.1 Ma (Lipman and Calvert, 2011).

Kohala shield-stage strata are assigned to the Pololū Volcanics (sheet 5; fig. 29). Fifty flow units from the lowest $140 \mathrm{~m}$ of exposed strata possess normal-polarity magnetization, which led to

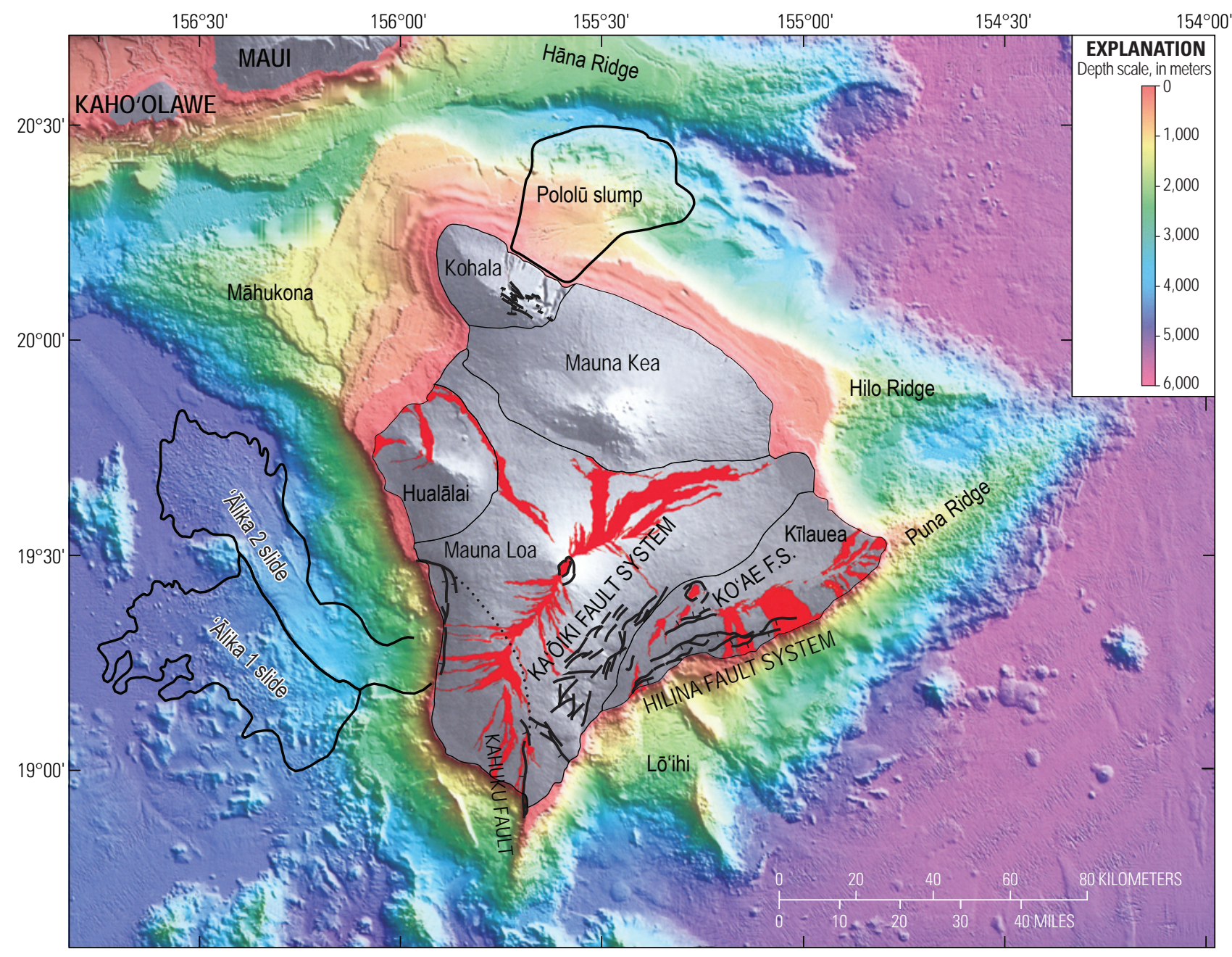

Figure 28. Bathymetric map for Island of Hawai'i, from Eakins and others (2003). Faults from Wolfe and Morris (1996a). Proposed buried trace of Kahuku fault shown dotted (from Lipman and others, 1990). Pololū slump from Smith and others (2002). 'Ālika 2 Slide from Lipman and others (1988). Red areas denote lava flows emplaced in the past 200 years. 


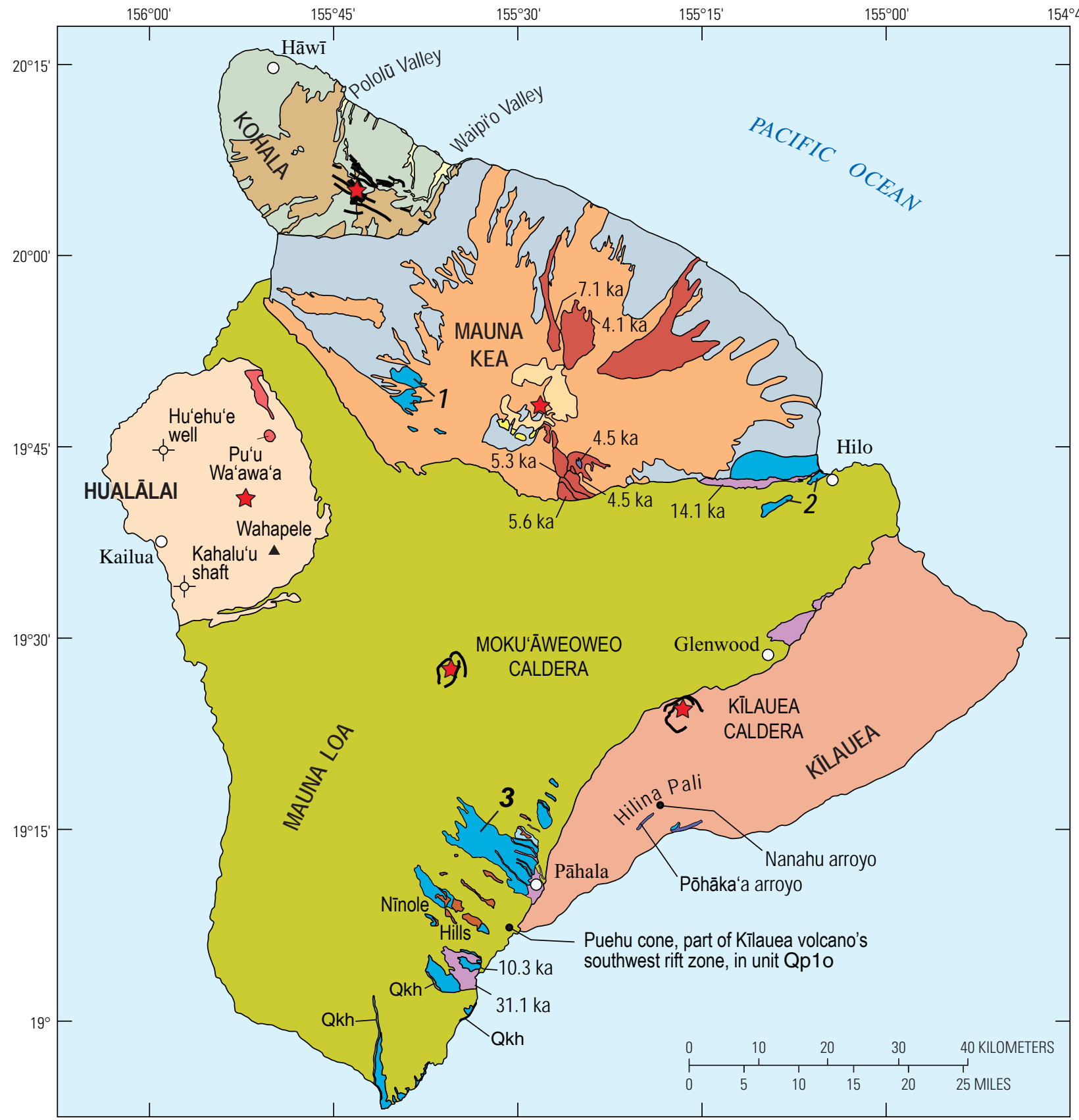

EXPLANATION

Alluvium (Holocene)-Kohala valleys

Tephra (Holocene and Pleistocene)—Primary and reworked fallout lapilli and ash from several sources. Numbered to indicate broad groupings:

1-Eolian deposits reworked from Holocene and Pleistocene eruptions of Mauna Kea

2-Homelani ash deposits (Pleistocene) of Buchanan-Banks (1993), derived from Mauna Loa or Mauna Kea

3-Pāhala Ash (Pleistocene) of previous workers, derived from one or both of Mauna Loa and Kïlauea

\section{Kïlauea Volcano}

Puna Basalt (Holocene and Pleistocene)

Hilina Basalt (Pleistocene)

\section{Mauna Loa volcano}

Ka'ū Basalt (units Qk1-5) (Holocene and Pleistocene)

Oldest part (unit Qk) (Pleistocene)

Qkh Kahuku Basalt (unit Qkh) (Pleistocene)

Ninole Basalt (Pleistocene)

Hualālai volcano

Hualālai Volcanics (Holocene and Pleistocene)

Wa'awa'a Trachyte Member (Pleistocene)

Mauna Kea volcano

Laupāhoehoe Volcanics (Holocene and Pleistocene)

Younger volcanic rocks member (Holocene and Pleistocene?)

Older volcanic rocks member (Holocene and Pleistocene)

Mākanaka Glacial Member (Pleistocene)

Hāmākua Volcanics (Pleistocene)

Waihu Glacial Member (Pleistocene)

\section{Kohala volcano}

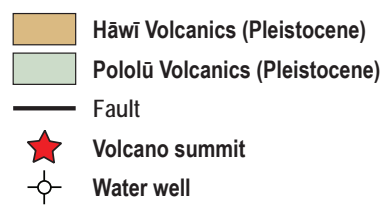

Figure 29. Map showing stratigraphic formations for volcanoes on Island of Hawai'i. 
the interpretation that the entire sequence is younger than $0.78 \mathrm{Ma}$ (Doell and Cox, 1965). Radiometric ages are mostly in the range from 0.45 to $0.32 \mathrm{Ma}$ (fig. 30) (McDougall, 1964; Lanphere and Frey, 1987). Three ages in the range 0.27-0.25 Ma were portrayed by Spengler and Garcia (1988, their fig. 2) and ascribed to G.B.

Dalrymple (unpub. data); $2 \sigma$ error is about $\pm 0.012 \mathrm{Ma}$ as estimated by scaling from the published figure. These ages are not included in our database owing to their ambiguous details.

Overlying the Pololū Volcanics is the postshield-stage Hāwī Volcanics, which ranges compositionally from hawaiite to trachyte (fig. 31). Most Hāwī ages range from 0.26 to $0.14 \mathrm{Ma}$ (fig. 30). The oldest of these ages may instead belong to a Pololū volcanic layer, on the basis of its low phosphorus content and stratigraphic position beneath a porphyritic Pololū lava flow (Spengler and Garcia, 1988). Regardless, the time interval that separates Pololū and Hāwī volcanic episodes is exceedingly brief, as first noted by Spengler and Garcia (1988).

Not tabulated in our database are five or six ages from Hāwī lava flows that are difficult to assess because they have never been published except by way of the small figure showing the distribution of Hāwī ages (Spengler and Garcia, 1988, their fig. 2). Two of these correspond to ages of 0.116 and $0.137 \mathrm{Ma}$, as determined by scaling from the graphical presentation of Spengler and Garcia (1988). Presumably the younger of these was the basis for assigning an age of $0.120 \mathrm{Ma}$ as the young limiting age of the Hāwī Volcanics (Wolfe and Morris, 1996a). The $2 \sigma$ error, also determined by scaling, corresponds to \pm 0.011 m.y.
The Hāwī Volcanics may contain strata younger than $0.12 \mathrm{Ma}$. For example, replicate ages of about $0.06 \mathrm{Ma}$ were obtained from two samples of the same lava flow on the volcano's east flank, collected about $170 \mathrm{~m}$ apart near the east rim of Waipi'o Valley (McDougall and Swanson, 1972). In a separate study, replicate ages of about 0.08 Ma were obtained from two sites on a west-flank lava flow (Malinowski, 1977). These four youngest Hāwī ages, which lie apart from other Hāwī ages on figure 30, might be viewed skeptically, and two of them have been challenged directly. The young east-flank ages $(0.064 \pm 0.004$ and 0.061 $\pm 0.002 \mathrm{Ma}$; McDougall and Swanson, 1972), which are disputed by Wolfe and Morris (1996a), were obtained from a lava flow that reportedly lies beneath a Mauna Kea flow with an age of $0.187 \pm 0.080 \mathrm{Ma}$ (Wolfe and others, 1997). The young west-side ages have not been tested by subsequent experiments. In summary, the Hāwī Volcanics is probably at least as young as about $0.12 \mathrm{Ma}$, conceivably younger. We accept the 0.12-Ma age limit as a conservative estimate for the end of Hāwī volcanism but find the question of youngest age yet to be rigorously answered.

Kohala is notable for several geomorphic features, all of which may be related to a large landslide or slump from its northeast side late in Pololū time (Moore and others, 1989). In plan view, the northeast coast has a prominent indentation extending along $20 \mathrm{~km}$ of shoreline from Waipi 'o to Pololū Valleys (fig. 28; valleys labeled on fig. 29). Large stream valleys have cut deeply into the volcano, perhaps a consequence of stream gradients thrown out of equilibrium when the landslide

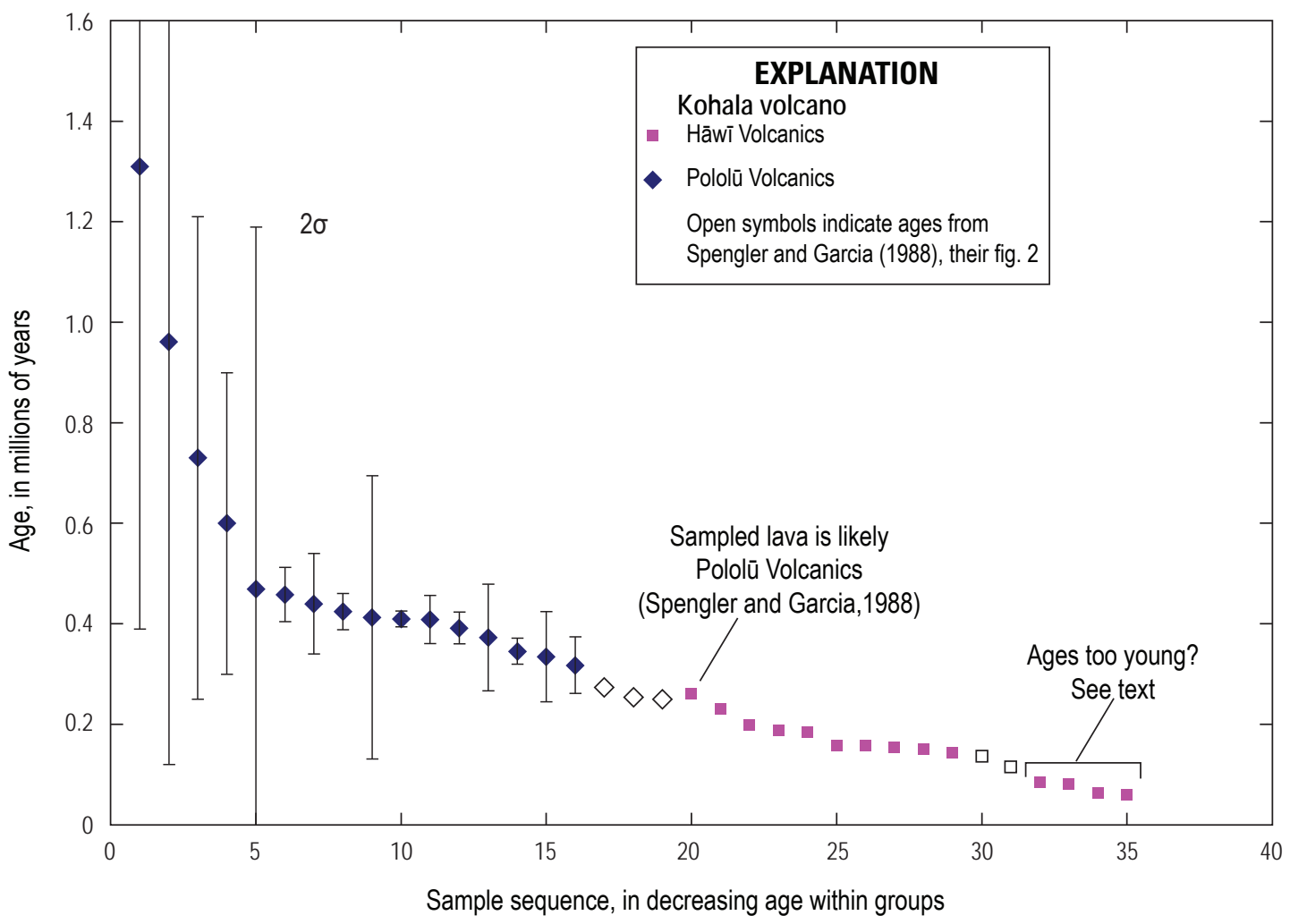

Figure 30. Radiometric ages from Kohala volcano, Island of Hawai'i. Data from Evernden and others (1964), McDougall (1969), Dalrymple (1971), McDougall and Swanson (1972), Malinowski (1977), Lanphere and Frey (1987), and G.B. Dalrymple, in Spengler and Garcia (1988). 


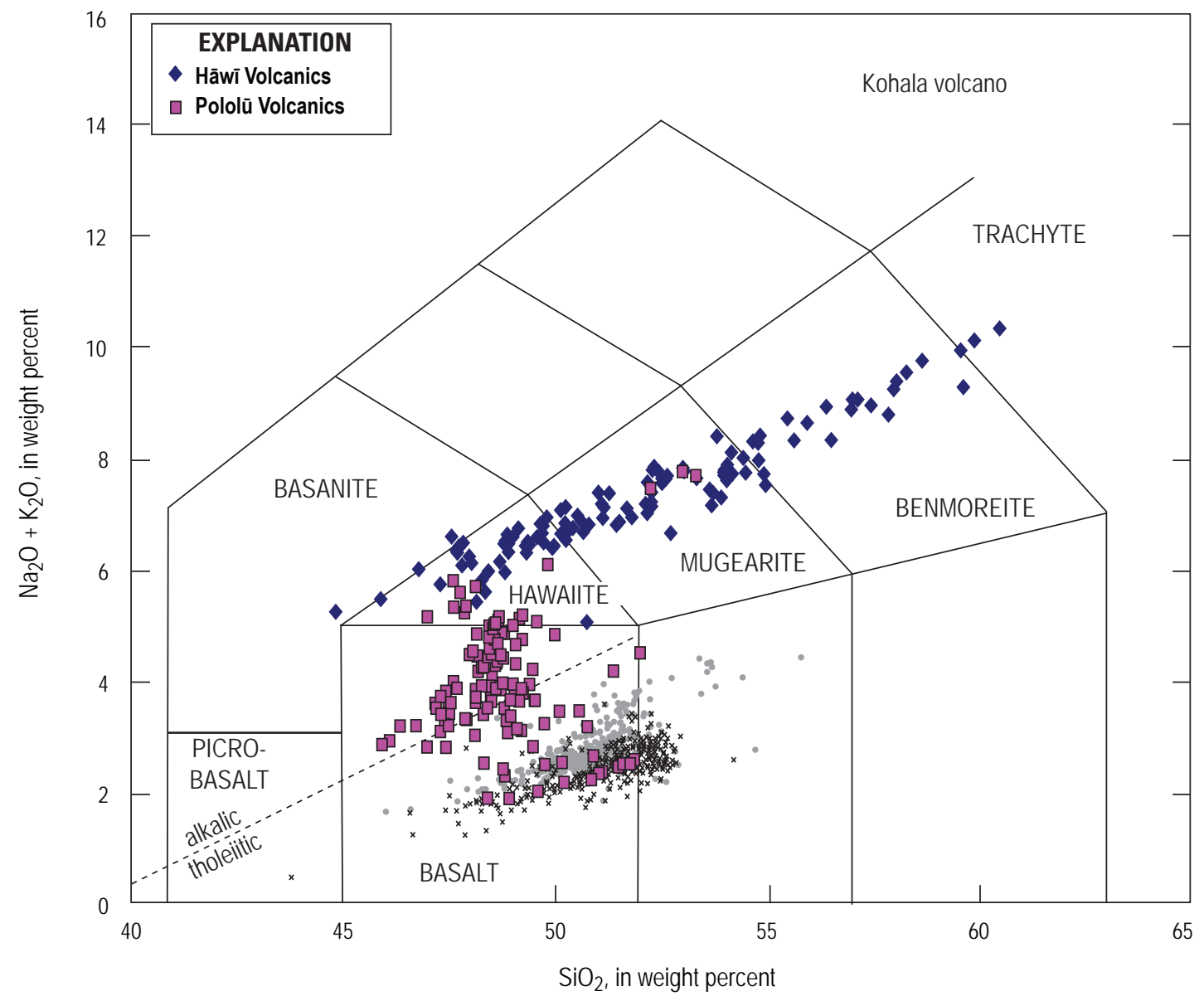

Figure 31. Alkali-silica $\left(\mathrm{Na}_{2} \mathrm{O}+\mathrm{K}_{2} \mathrm{O}\right.$ versus $\left.\mathrm{SiO}_{2}\right)$ diagram for analyzed rocks from Kohala volcano, Island of Hawai'i. Grid fields labeled for those commonly used in Hawaiian islands; grid boundaries and Mauna Loa-Kilauea data (small black x and gray dot symbols) referenced in figure 2 caption. Data from Wolfe and Morris (1996b, 235 analyses).

severed their paths. The summit of the volcano has faults that parallel the indented northeast coastline. "The resulting structural depression is regarded as a pull-apart graben developed at the head of the landslide" (Moore and others, 1989, p. 17,477). No faults are mapped connecting this summit graben with the coastal reach, however, so we prefer an interpretation in which the landslide headscarp is at the coast and the graben formed as a farfield response to changes in stress precipitated by the landslide. Regardless, volcanism continued after the landslide and after much of the large valleys had been carved, inasmuch as Hāwi lava flows draped the valley walls and flowed down into Pololū Valley (as first mapped by Stearns and Macdonald, 1946). Recent seafloor mapping has further elucidated details of the Pololū slump (Smith and others, 2002).

\section{Mauna Kea}

On an island rich in superlatives, Mauna Kea brings its own title as highest summit in the State of Hawai' $i$ and the State's only volcano known to have been glaciated. It is more symmetrical than other volcanoes on the island, lacking welldefined rift zones.
The oldest exposed volcanic strata of Mauna Kea are assigned to the Hāmākua Volcanics. The Hāmākua Volcanics unit is found on all flanks, although the south-flank outcrops are limited. It was divided into lower and upper members by Stearns and Macdonald (1946), of which the lower was later assigned to shield-stage volcanism and the upper to the postshield stage (Macdonald and others, 1983; Langenheim and Clague, 1987). The contact separating lower and upper members was described as gradational and, in many places, indefinite; consequently it was mapped only on the east flank and depicted by way of a small-scale figure (Stearns and Macdonald, 1946, their fig. 31). In contrast, Wolfe and others (1997) interpreted the Hāmākua's origin entirely as postshield volcanism and stated that no shieldstage strata are exposed, an interpretation based on the geochemical characteristics of lava in the Hāmākua Volcanics. They noted, however, that lava flows exposed near sea level in Laupāhoehoe gulch may represent the uppermost part of a transition zone between the tholeiitic shield and overlying alkaline (postshield) strata (Wolfe and others, 1997, p. 122).

Some more recent insight into this stratigraphic dilemma is found in the geochemical analyses from deeper Mauna Kea strata that were penetrated by the Hawai'i Scientific Drilling Program's 
phase-1 drill hole near Hilo (fig. 32). Tholeiitic basalt lava flows below 340-m depth form a linear array similar to that of shield volcanoes like Kīlauea and Mauna Loa. Mauna Kea strata above have chemical compositions that spread broadly from tholeiitic to alkalic basalt, largely coincident with the field defined by samples from the Hāmākua Volcanics sampled at the surface (Rhodes, 1996). The distinction, as seen in figure 32, supports the view that no typical shield-stage strata are exposed today at Mauna Kea and that the Hāmākua Volcanics is therefore entirely postshield in origin (Wolfe and others, 1997). A corollary is that neither East
Moloka ${ }^{\prime} i$ nor Haleakalā volcanoes have their shield-stage strata exposed today, if the total alkalis-silica diagrams are definitive (figs. 15, 25).

The age of the Hāmākua Volcanics is known from K-Ar dating. The radiometric ages range widely, in part because some samples have large analytical error. The span of likely age for the exposed Hāmākua sequence is as old as $300 \mathrm{ka}$ and as young as 74-64 ka, at the 95-percent confidence level (fig. 33). A similar interpretation, albeit slightly narrower-about 265 to $65 \mathrm{ka}$-was offered previously by Wolfe and others (1997).

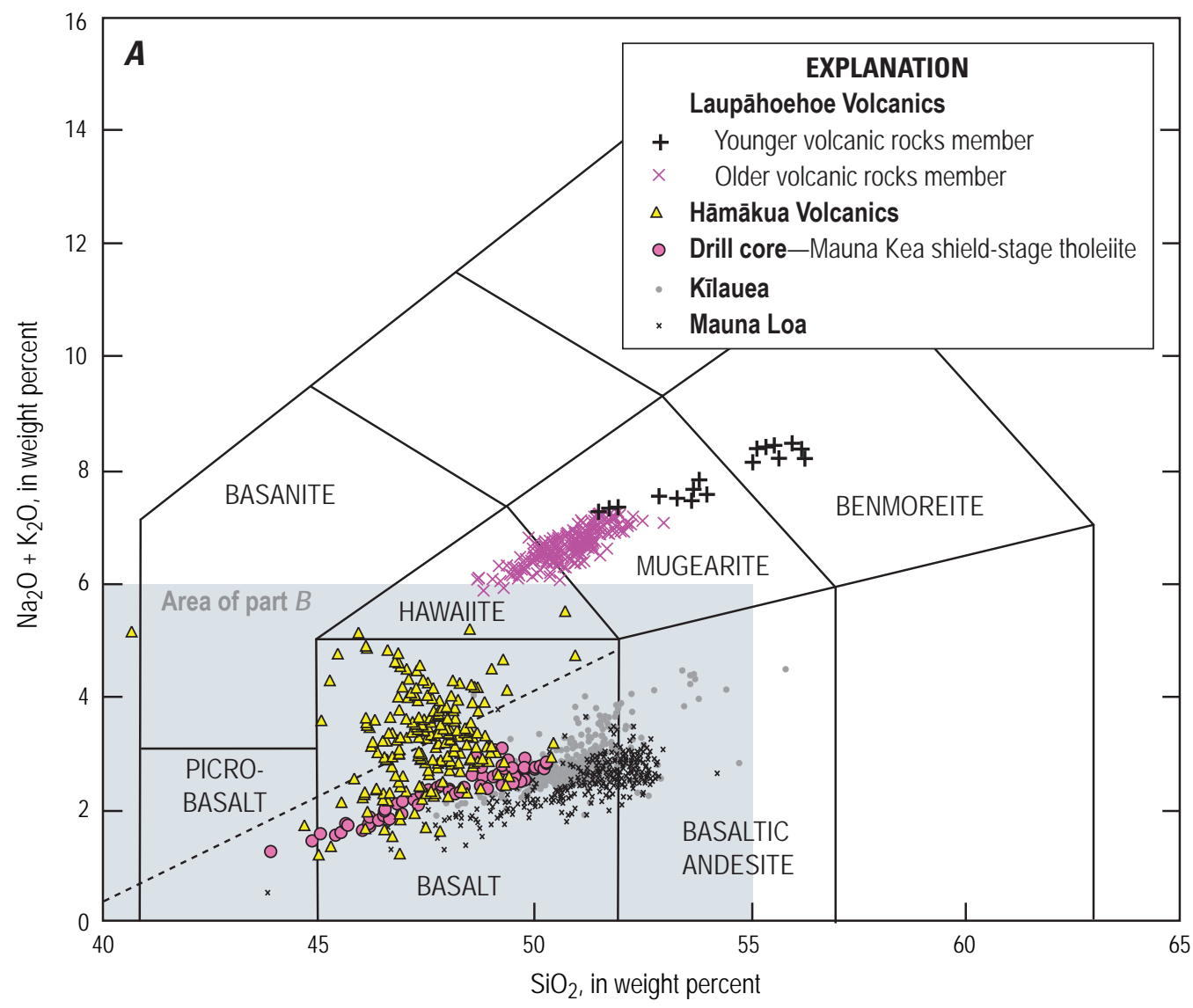

Figure 32. Alkali-silica $\left(\mathrm{Na}_{2} \mathrm{O}+\mathrm{K}_{2} \mathrm{O}\right.$ versus $\mathrm{SiO}_{2}$ ) diagram for rocks from Mauna Kea volcano, Island of Hawaii, as sampled at the surface (Wolfe and Morris, 1996b) and in Hilo drill hole (Rhodes, 1996). Grid boundaries and Mauna Loa-Kìlauea data (small black $x$ and gray dot symbols) referenced in figure 2 caption. Shaded box in lower main graph is enlarged in the overlapping inset. Ages from drill-core samples from Sharp and others (1996). Division of Hāmākua Volcanics into older and younger parts corresponds to Hopukani Springs and Liloe Spring Volcanic Members, respectively, as annotated in table 1 of Wolfe and others (1997).

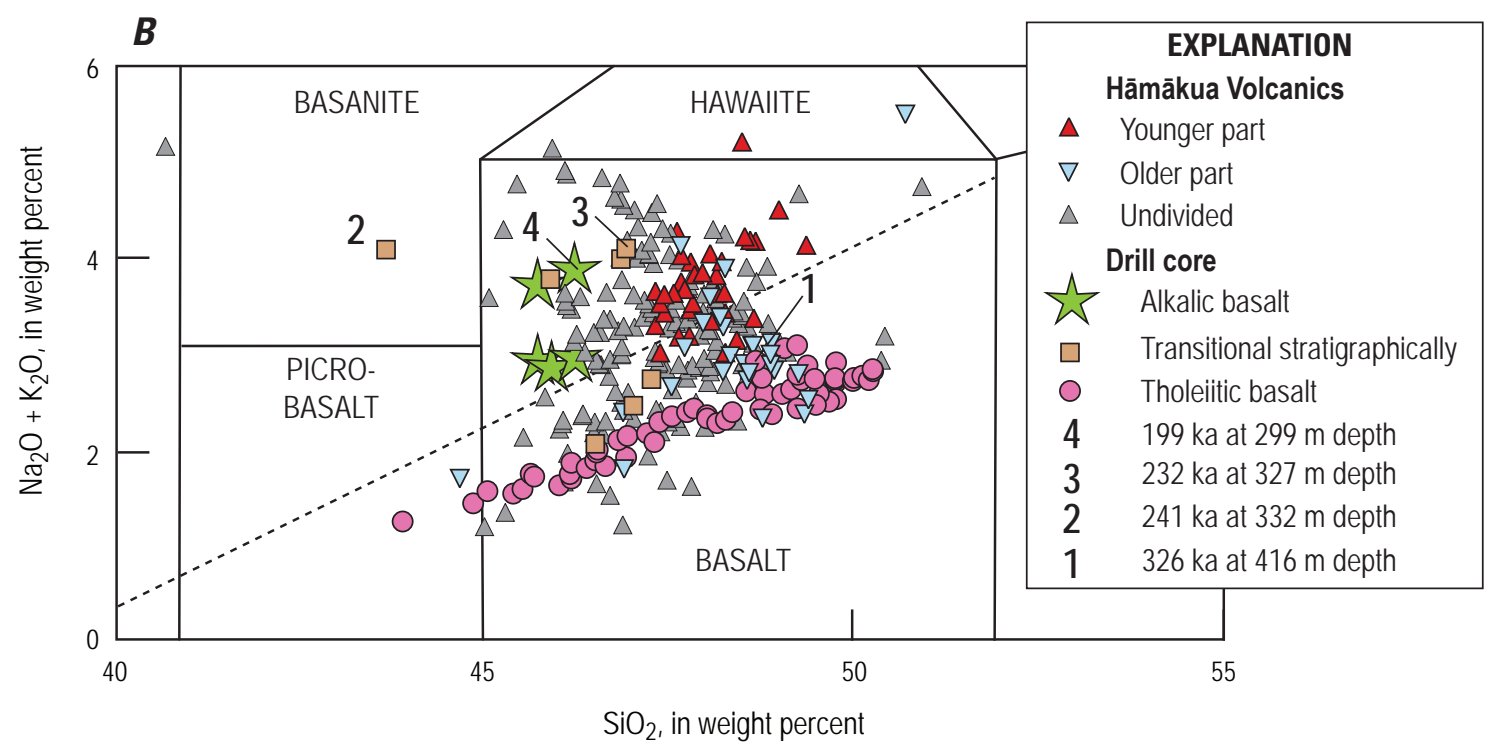




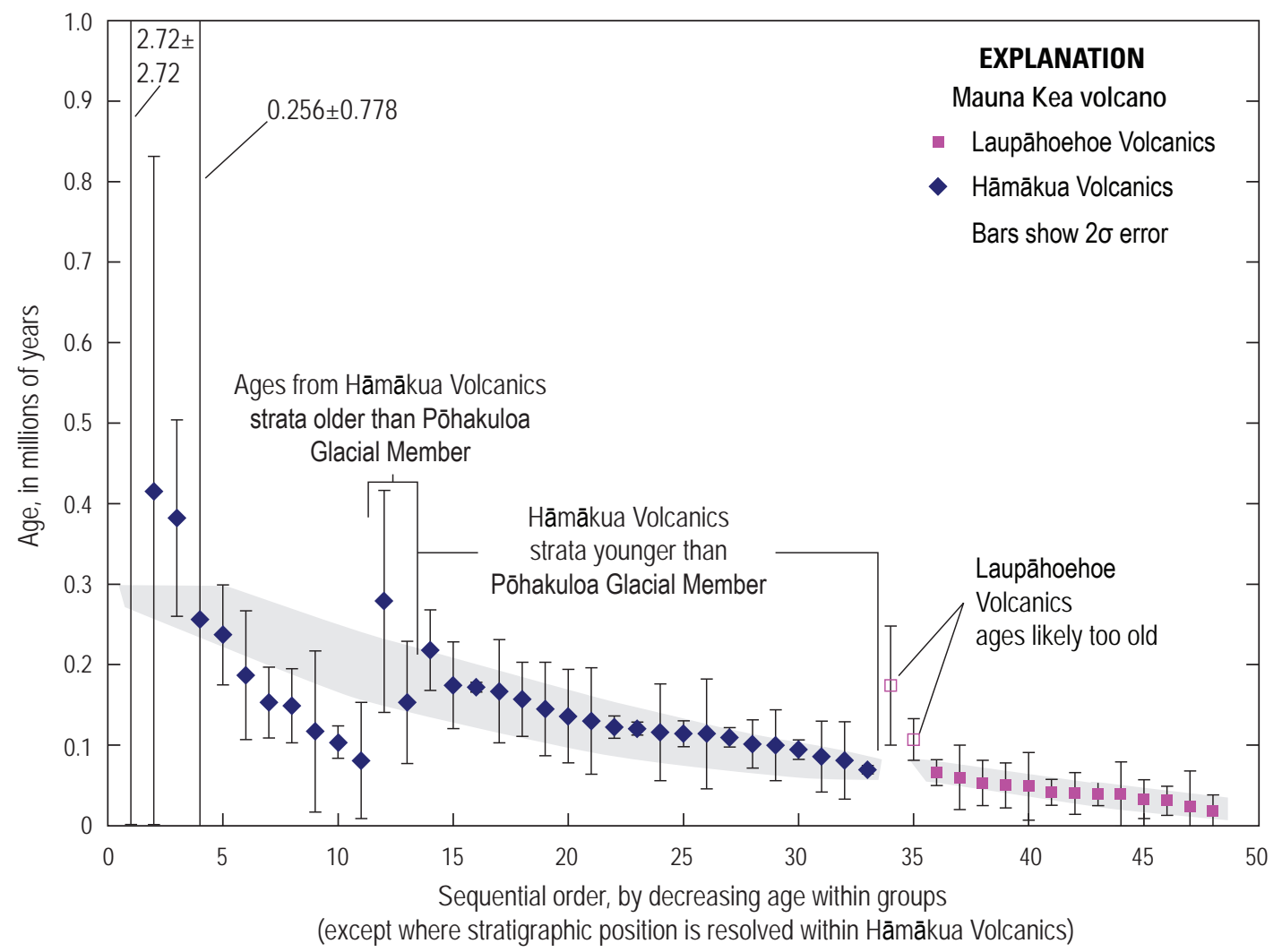

Figure 33. Potassium-argon ages from Mauna Kea's surface volcanic rocks. Data from Porter (1979) and Wolfe and others (1997). Samples 1 through 11 (in sequential ordering scheme), from the Hāmākua Volcanics, undivided, were collected from exposures on the lower flanks of Mauna Kea. Samples 12 through 33 are grouped according to stratigraphic position below or above the Pōhakuloa glacial member; these divisions correspond to the Hopukani Springs and Liloe Spring Volcanic Members, respectively (Wolfe and others, 1997). Open symbols, Laupāhoehoe Volcanics ages likely too old.
On the upper flanks of Mauna Kea, two glacial sequences, including till and outwash, are interbedded with the upper part of the Hāmākua Volcanics. The older of these is the Pōhakuloa Glacial Member; the younger is the Waihū Glacial Member. The Pōhakuloa Glacial Member is small in outcrop area and for that reason was not shown on the published compilation of Hawai'i Island geology (Wolfe and Morris, 1996a). We have added it to our map (map sheet 5) by digitizing it from the larger scale map of Mauna Kea (Wolfe and others, 1997), in order to depict all the glacial units.

The latest episodes of Mauna Kea volcanism are assigned to the Laupāhoehoe Volcanics, which consists chiefly of hawaiite, mugearite, and benmoreite lava flows. The Laupāhoehoe has been subdivided into various members by Wolfe and others (1997), all of which are shown on this map.

Mauna Kea's youngest lava flows, in the upper part of the Laupāhoehoe Volcanics, are dated by way of nine charcoal ages from beneath the lava flows of six stratigraphic units. These ages range from 7,100 to 4,400 radiocarbon years (Porter, 1979; Wolfe and others, 1997). Calibrated ages correspond to the time between about 8,200 and 4,580 yr ago (fig. 34). As stated by Wolfe and Morris (1996a, p. 13), these ages probably date the youngest, but not the oldest, lava flows in the upper part of the Laupāhoehoe Volcanics (their "younger volcanic rocks member"). Hence this stratigraphic volcanic member encompasses rocks of Holocene and possibly Pleistocene age.

Some reports have cited a ${ }^{14} \mathrm{C}$ age of 3,600 yr before present (B.P.) as the most recent volcanic event (for example, Porter, 1979). This age was derived by interpolating depth-age relations for tephra layers in sediment of Lake Waiau, near Mauna Kea's summit (Woodcock and others, 1966). In that experiment, two radiocarbon ages from organic matter (algae planktonic spicules and frustules) in the sediment were obtained from depths of about 1 and $2 \mathrm{~m}$; the ages are $2,270 \pm 500$ and $7,160 \pm 500{ }^{14} \mathrm{C}$ yr B.P., respectively (Woodcock and others, 1966; Ives and others, 1967). Calibrated ages correspond to the intervals 9,190-6,958 yr B.P. at 2-m depth and 3,477-1,182 yr B.P. at 1-m depth (inset, fig. 34). Porter (1973) mentioned a tephra layer at $1.3-\mathrm{m}$ depth and reported an approximate age of $3,600 \pm 300{ }^{14} \mathrm{C} \mathrm{yr}$ for it as the evidence of youngest volcanism. This age has also been reported as "3,300 years" (Porter and others, 1987; Moore and Clague, 1992). A Mauna Kea eruption is the most likely source for the drill-hole tephra, but no compositional data unequivocally relate the ash to Mauna Kea.

A graphical estimate for the calibrated age of the 1.3-m-deep tephra is in the range 5,380-3,130 years B.P., which overlaps substantially with ages of eruptions known from dated lava flows (fig. 34). Indeed, correlation with known events seems the simplest explanation for the origin of the tephra in the Lake Waiau drill core, in the absence of chemical or mineralogic evidence to negate the correlation. Of course, deriving the age of youngest volcanism by this analysis is hampered by the large analytical errors on the ages from bounding sedimentary strata and the assumption of unvarying sediment accumulation during the interim period. We take a conservative approach, citing "about $4.6 \mathrm{ka}$ " as the age of most recent volcanism, which concurs with a similar finding by Wolfe and Morris (1996a) but reported here in calibrated, not radiocarbon, years.

Mauna Kea's three glaciations have scoured lava flows at higher altitudes, which created striated surfaces that lead down to the moraines and outwash left by the glaciers. Some lava flows in the summit area have ice-contact features such as steep margins, pillows, glassy surfaces, spiracles, and palagonitized zones (Porter, 1987). The evidence for ice-contact features is found in 


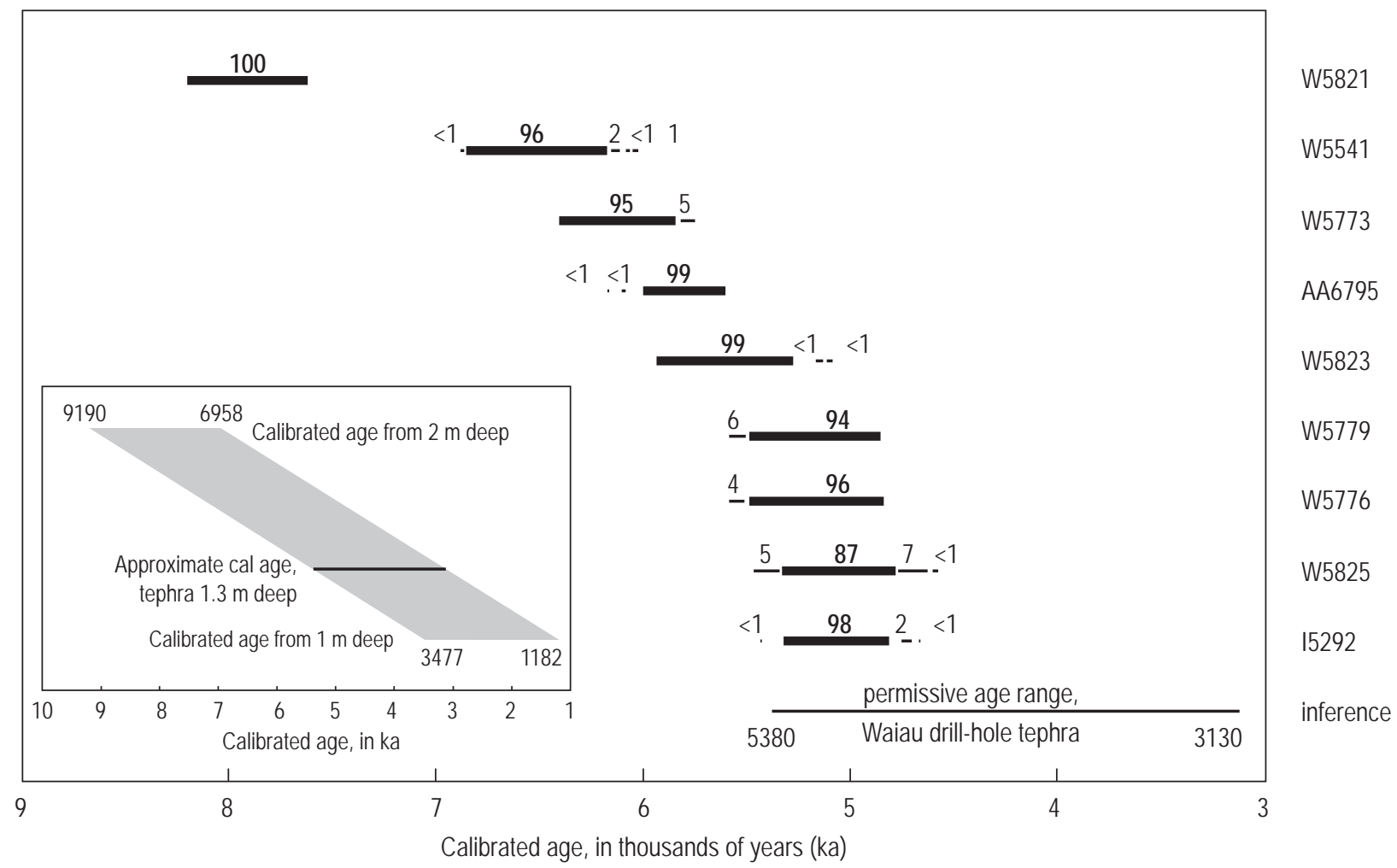

Figure 34. Calibrated ages from charcoal beneath Holocene volcanic rocks, Mauna Kea volcano, Island of Hawai'i. Sample numbers along right axis. Calibration from radiocarbon to sidereal ages produces a spectrum of likely age ranges, and these are shown as horizontal bars. Solely for emphasis, bars are bold where encompassing more than 85 percent probability for the possible span of each calibrated age. Thinner bars show much less likely age ranges. Numbers above bars show the probability (percent) that a sample's age corresponds to that designated interval. Inset shows graphical solution for simply estimated age range of tephra in a shallow drill hole at summit; that age range labeled "inference" on main graph.

deposits originating beneath the Mākanaka and Waihū ice caps. The Pōhakuloa glaciation likely produced similar effects, but none has been found among its sparse outcrops (Porter, 1987).

The estimated age and duration of the three glaciations have varied as the number of bracketing, dated lava flows increases; thus we report the interpretations offered by Wolfe and others (1997). Even so, the large analytical error for the ages precludes more than a general estimation for each. Knowledge from worldwide correlations, such as the cooling of ocean water as correlated with changes in oxygen isotope data, is critical to the final analysis. The oldest event, the Pōhakuloa, corresponds to marine oxygen isotope stage 6 , so it probably occurred sometime between about 180 and $130 \mathrm{ka}$. The Waihū Glacial Member was probably deposited during oxygen isotope stage 4 , or roughly 80-60 ka. The youngest, the Mākanaka, was underway by about $40 \mathrm{ka}$. It had ended by about $13 \mathrm{ka}$, the time when Lake Waiau became an ice-free depression capable of accumulating sediment (Peng and King, 1992). A small discontinuous body of permafrost was found at shallow depth beneath one of the summit cinder cones of Mauna Kea in the late 1960s, and another likely occurrence in a nearby cone was mentioned in passing (Woodcock, 1974). The two ice bodies persist: that described in detail by Woodcock (1974) has shrunk in volume by an order of magnitude and is expected to disappear soon; the other is still more than $50 \mathrm{~m}$ wide (Schorghofer and others, 2017).

\section{Hualālai}

Travelers arriving at, or departing from, Kailua-Kona's Keāhole International Airport taxi across alkali basalt lava flows emplaced in A.D. 1800-01 (fig. 35), Hualālai's youngest volcanic products (Kauahikaua and others, 2002). Hualālai volcano's subaerial edifice is completely coated with these and other postshield-stage alkali basalt, hawaiite, and trachyte, all assigned to the Hualālai Volcanics (fig. 36). Vents for the Hualālai Volcanics define rift zones trending northwest and southeast from the volcano's summit. These zones are displaced by $4 \mathrm{~km}$ from the volcano's dense substructure, which presumably marks the pathways for eruptions of the shield-building stage (Kauahikaua and others, 2000).

Shield-stage lava flows are found offshore along the volcano's northwest rift zone (Clague, 1982; Clague, 1987b; Hammer and others, 2006). Tholeiitic lava flows were also intercepted in the Kahalu' $u$ water well (Moore and others, 1987), an inclined shaft that penetrates about $230 \mathrm{~m}$ of stratigraphic section from a surface altitude of $175 \mathrm{~m}$ (R.T. Holcomb, unpub. USGS report for Hawaiian Volcano Observatory, 1975). The depth for the Kahalu'u samples has not been reported, but tholeiite apparently occurs as shallow as $75 \mathrm{~m}$ below surface (Clague, 1987b, his fig. 1 caption). Tholeiitic lava flows were also collected from below 440-m depth in the Hu'ehu'e water well (fig. 29), north of 


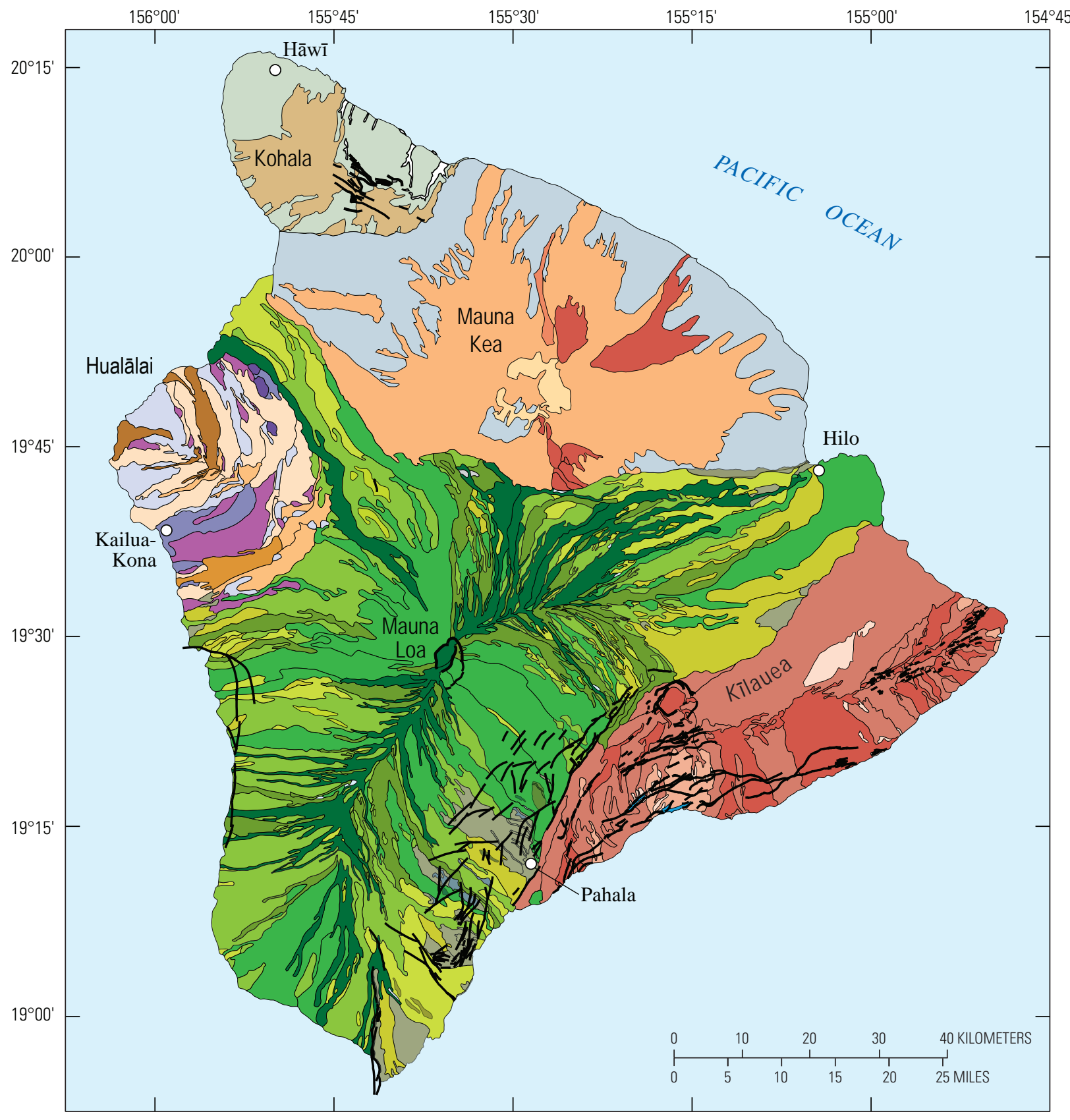

\section{EXPLANATION}

\section{Hualālai Mauna Kïlauea}

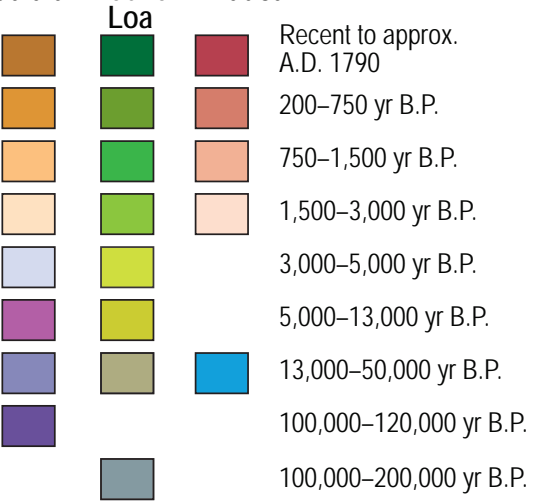

Figure 35. Map showing distribution of volcanic rocks by age and volcano for the Island of Hawai'i. Generalized from this publication's digital map database. Geology from Wolfe and Morris (1996a). Bold black lines are faults; B.P., before present; A.D., anno Domini.
Kohala Mauna Kea

4,000-7,000 yr B.P. 7,000-13,000 yr B.P.

Glacial deposits $13,000-65,00$ yr B.P. $65,000-300,000$ yr B.P. $120,000-250,000$ yr B.P. 250,000-600,000 yr B.P.

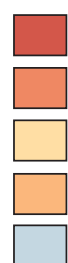




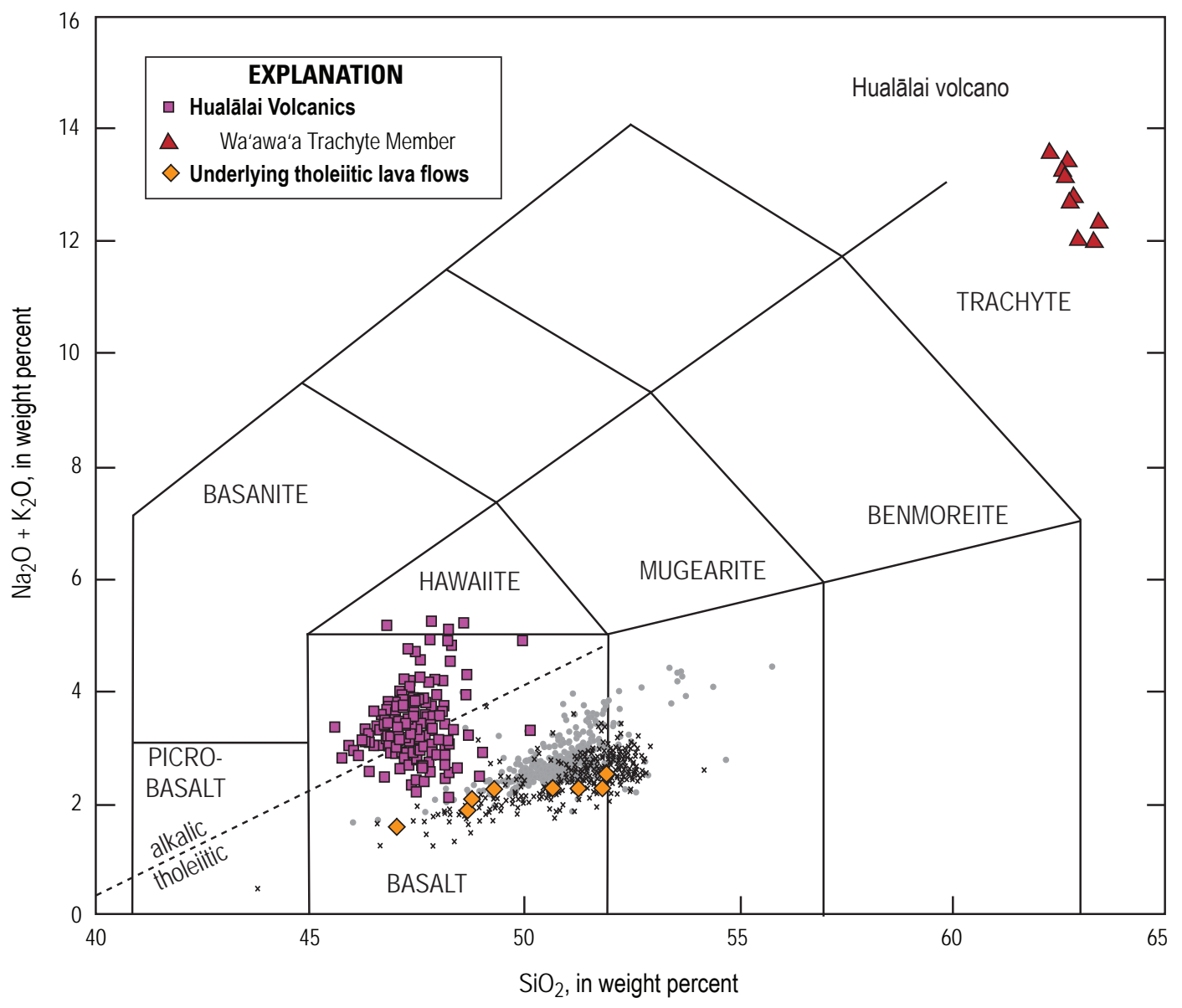

Figure 36. Alkali-silica $\left(\mathrm{Na}_{2} \mathrm{O}+\mathrm{K}_{2} \mathrm{O}\right.$ versus $\left.\mathrm{SiO}_{2}\right)$ diagram for analyzed rocks from Hualālai volcano, Island of Hawai'i. Grid fields labeled for those commonly used in Hawaiian islands; grid boundaries and Mauna LoaKïlauea data (small black $x$ and gray dot symbols) referenced in figure 2 caption. Hualālai chemical data from Wolfe and Morris (1996b, 106 analyses), Clague (1987b, 2 analyses), Moore and others (1987, 4 analyses), J.G. Moore and Clague, 1987 (2 analyses), and Cousens and others (2003, 7 analyses).
Kailua-Kona (Clague, 1987b), corresponding to altitudes lower than $14 \mathrm{~m}$ (sea-level datum). Tholeiitic flows dredged from the volcano's west flank about $8 \mathrm{~km}$ south of Kailua-Kona are likely from Hualālai, but they lie within $2 \mathrm{~km}$ of Mauna Loa offshore lava of similar composition, so they were assigned cautiously (Moore and Clague, 1987). Hualālai's tholeiitic eruptions persisted until sometime after $130 \mathrm{ka}$ (Moore and Clague, 1992).

A widespread sequence of trachyte, the Wa'awa'a Trachyte Member, presumably marks the base of the Hualālai Volcanics. Erupted in part from $\mathrm{Pu}^{\prime} \mathrm{u} \mathrm{Wa}^{\text {'awa'a }}$ (fig. 29), a pumice cone on the north flank of Hualālai (Clague and Bohrson, 1991; Moore and Clague, 1991; Shea and others, 2017), the Wa'awa'a Trachyte Member is exposed as the 100-275-m-thick Pu'u Anahulu lava flow and penetrated by several water-well holes. Trachytic fragments were disgorged as xenoliths from vents southeast of the volcano's summit (Clague and Bohrson, 1991), so doubtless other vents are buried along the northwest rift zone or thereabouts. Numerous radiometric ages indicate that the trachyte was erupted sporadically for about 20,000 yr, from 114 to $92 \mathrm{ka}$ (Clague, 1987b; Cousens and others, 2003).

Hualālai is one of several Hawaiian volcanoes known to have had phreatic explosions at high altitude along its rift zone. The vent, Wahapele (fig. 29), at about 1,600 m altitude, disgorged blocks of country rock and shed a layer of light gray to white ash as thick as $3 \mathrm{~m}$ during activity that culminated by about 800-700 yr B.P. (Moore and Clague, 1991).

\section{Mauna Loa}

The world's largest volcano, Mauna Loa, has come to epitomize shield-stage volcanism. Its volume is in the range $65,000-80,000 \mathrm{~km}^{3}$ of lava flows, vent deposits, and intrusions, an estimate that includes the edifice above the ocean floor but also that created by the 8-9 km of load-induced subsidence of the Pacific plate beneath Mauna Loa's summit (Lipman, 1995; Robinson and Eakins, 2006). The volcano's growth has been accompanied by several large landslides. Deposits of these slides retain their geomorphic form on the ocean floor west of Mauna Loa (for example, Lipman, 1980; Lipman and others, 1988; Moore and others, 1989). The headwalls for these slides coalesce to encompass a large sector of Mauna Loa's west flank. Exposed today at the northern and southern onshore limit are two normal faults, the Kahuku and Kealakekua faults, on Mauna Loa's west flank. The headwall's trace between these faults has been masked by subsequent lava flows (fault shown dotted on figure 28 and map sheet 5), but it likely had subaerial exposure in excess of 1,500-2,000 m, exceeding the modern topographic expression of the Hilina fault system, a similar series of faults on Kîlauea.

Oldest of Mauna Loa's exposed subaerial rocks are lava flows of the Ninole Basalt, which forms the Ninole Hills (fig. 29). The Ninole Basalt is thought to be 0.2-0.1 Ma in age (Lipman and others, 1990) on the basis of several K-Ar ages (fig. 37), but the samples have low potassium content, low radiogenic argon 


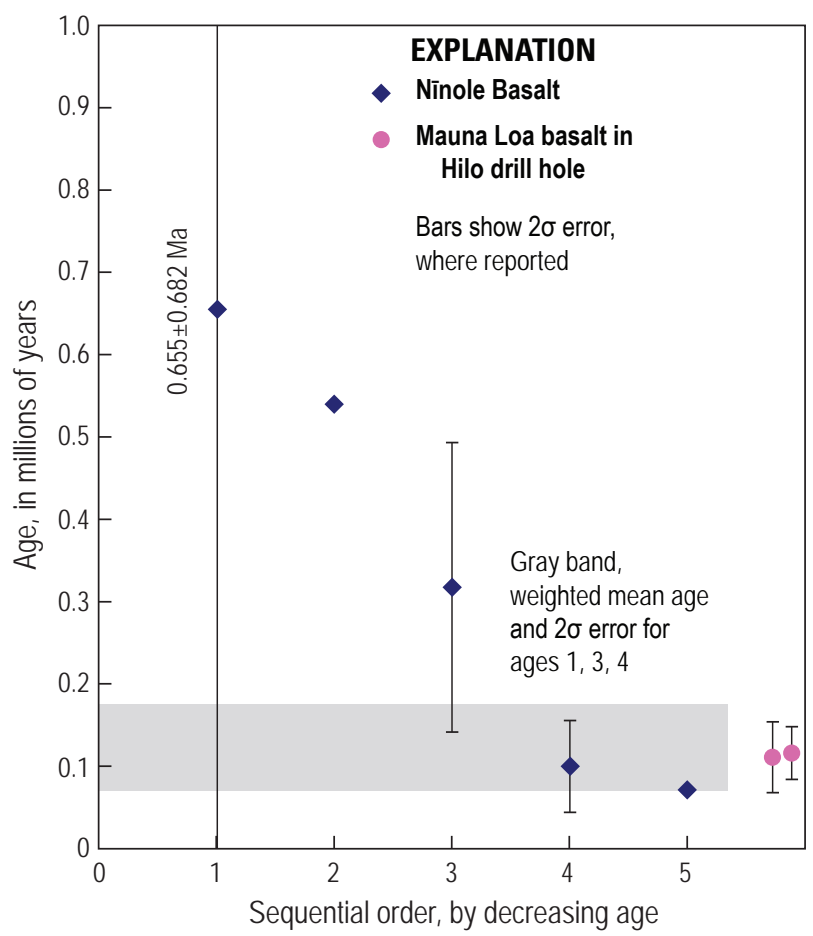

Figure 37. Radiometric ages from lava flows in the Ninnole Basalt (sampled in Ninole Hills and from Mauna Loa lava flows of similar age from the Hilo HSDP drill hole). Shown without analytical error are two Ninole Basalt ages from Evernden and others (1964), whereas the three others (from Lipman and others, 1990) were used to calculate weighted mean age and $2 \sigma$ error limit shown by gray band. Not shown are two ages from dikes that yielded impossibly old ages of 1.28 and $7.18 \mathrm{Ma}$ (Lipman and others, 1990). HSDP drill hole ages from Sharp and others (1996) and Sharp and Renne (2005).

yield, and fairly large analytical error — a problem that haunts the dating of young tholeiitic lava flows along the Hawaiian island chain. The Ninnole Hills form an erosionally dissected terrane against which younger Mauna Loa lava flows have banked. Their depth of incision and minor topographic isolation from the slope of Mauna Loa's south flank are thought to result from rapid erosion following an abrupt change in stream-base equilibrium after an ancestral slump truncated the island shoreline seaward of the hills (Lipman and others, 1990).

Mauna Loa strata similar in age to the Ninole Basalt were dated from two drill holes on the lower east flank (fig. 37). A ${ }^{40} \mathrm{Ar} /{ }^{39} \mathrm{Ar}$ plateau age of $132 \pm 64 \mathrm{ka}(2 \sigma)$ from $268 \mathrm{~m}$ depth was viewed cautiously (Sharp and others, 1996) owing to a discordant spectrum. It is within the range of a similar ${ }^{40} \mathrm{Ar} /{ }^{39} \mathrm{Ar}$ isochron age, 122 $\pm 86 \mathrm{ka}$, from 245-m depth (Sharp and Renne, 2005).

Younger lava flows from Mauna Loa are divided into two formations on the basis of an intervening thick ash deposit found on the lower southwestern flank of the volcano. The older of the two is the Kahuku Basalt, which is sparsely exposed in two escarpments on the lower southwest rift zone. The younger, and far more widespread, is the Ka' $\bar{u}$ Basalt (fig. 29).

The intervening ash deposits are probably best known from the area near Pāhala, from which comes the name most commonly assigned to them, Pāhala Ash. The unit consists of numerous primary and reworked beds that accumulated over a substantial period of time. Most of the glass is devitrified and altered, which has hindered efforts to subdivide the unit in a way that leads to new stratigraphic or structural insight. It had been suggested that the main body of the ash near Pāhala town is at least $30 \mathrm{ka}$ (Lipman and Swenson, 1984) on the basis of a radiocarbon age of 31,100 $\pm 900{ }^{14} \mathrm{C}$ yr B.P. from a lava flow in the overlying Ka ${ }^{6} \overline{\mathrm{u}}$ Basalt (sample W3935; Rubin and others, 1987). But subsequent dating and mapping indicates that younger ash deposits predominate, mainly with ages from about 30 to $13 \mathrm{ka}$ (F.A. Trusdell, oral commun., 2006). These ages are from charcoal beneath Mauna Loa lava flows interbedded with the ash along the southwest rift zone, mapped as the oldest part of the Ka' $\bar{u}$ Basalt. This latter age range - 30 to $13 \mathrm{ka}$-also characterizes a similar thick sequence where dated on nearby Kīlauea Volcano, discussed later.

Was Mauna Loa glaciated? The volcano had sufficient highaltitude area to maintain an ice cap in the time of the last glaciation 25-15 ka. This estimate is drawn after correcting Mauna Loa's current altitude downward by 150-300 $\mathrm{m}$ to compensate for lava accumulation at rates that characterize shield growth (see Sharp and others, 1996; Sharp and Renne, 2005). Till and outwash deposits that may have resulted from glaciation would now be buried throughout the summit area. Suitably old strata lie below 2,000 m altitude, too low to carry the evidence of glaciation if the example from Mauna Kea is a useful guide. Today, sporadic ice persists each summer in caves above 3,700 m, serving as an emergency source of water in the otherwise arid summit. But unlike Mauna Kea, no permafrost zone has been mapped at Mauna Loa. The aforementioned revision in age for much of the Pāhala Ash raises the tantalizing possibility that phreatomagmatic explosive eruptions related to glaciation at Mauna Loa may have been a contributing factor for the ash genesis (D.A. Swanson, oral commun., 2005).

Thin deposits of substantially younger explosion debris mantle the northwest and southeast rims of Moku'āweoweo caldera, at the summit of Mauna Loa. These deposits, which include blocks as large as $1 \mathrm{~m}$ across, originated from the caldera and were interpreted as phreatic in origin with no juvenile magmatic material (Macdonald, 1971). Those at the summit are probably only slightly younger than 1,000 yr, on the basis of recently obtained exposure ages of the deposits and ages ranging from 1,000 to 1,250 years from underlying lava flows (Trusdell and Swannell, 2003), but other deposits $3 \mathrm{~km}$ to the southeast are overlain by lava flows from the summit and likely are older, indicating at least two episodes of phreatic explosions. These explosions may have been driven by magma as it intercepted ground water perched in the dike swarms of the upper rift zones. Perhaps more likely, trapped $\mathrm{CO}_{2}$ may have been the expulsive agent (D.A. Swanson, written commun., 2006).

\section{Kīlauea}

Kîlauea, youngest of the emergent volcanoes in Hawai' $i$, is also perhaps the most active volcano in the world. The distinction certainly applies from the point of view of historical lava-flow production. (Some have argued that Stromboli volcano, Italy, has a longer record of perennial activity, disgorging tephra frequently during the past 2,000 years.) A long-lived eruption from 1983 to 2018 (see bibliography in Heliker and Mattox, 2003) has continued the shield-building process at Kîlauea. 
K1̄lauea's oldest strata include preshield-stage alkalic basalt as old as about $275 \mathrm{ka}$, the only Hawaiian volcano besides submarine Lō'ihi and possibly Hualālai where these earlyerupted rocks haven't been completely buried by shield lava (Lipman and others, 2002; Sisson and others, 2002; Hammer and others, 2006). The preshield alkalic samples were collected from the southern submarine slope by remotely operated submersibles. Ages are chiefly in the range 275-225 ka (fig. 38) (M.A. Lanphere, in Lipman and others, 2002) and presumably represent submarine lava flows.

Drill holes on Kīlauea's east rift zone have penetrated below the subaerial-submarine boundary—at about 738-787 m depth for hole SOH-1, corresponding to $551 \mathrm{~m}$ below sea level (Trusdell and others, 1999). The drilled sequence is entirely in tholeiitic lava flows and dikes (fig. 39). Ages from the different core holes are as old as about 450 ka (Guillou and others, 1997; Quane and others, 2000), and the older ages form a roughly linear age-depth curve (fig. 38). (In our graphical analysis we ignore an unreasonably old age of about 1.2 Ma from 1,808-m depth in SOH-1 described by Guillou and others, 1997).

Paleomagnetic inclination and intensity data from the $\mathrm{SOH}-1$ samples suggest the strata in the hole are younger than several of the ages might suggest, on the basis of correlation with shortlived magnetic reversals known from elsewhere in the world. That, and the constraining ages already mentioned for early Kîlauea alkaline fragments (fig. 38), indicates that the entire tholeiitic shield stage is younger than about $225 \mathrm{ka}$.

From surface mapping, Kîlauea's subaerial stratigraphic sequence is divided into three major units: from oldest to youngest they are (1) the Hilina Basalt, (2) an overlying thick accumulation

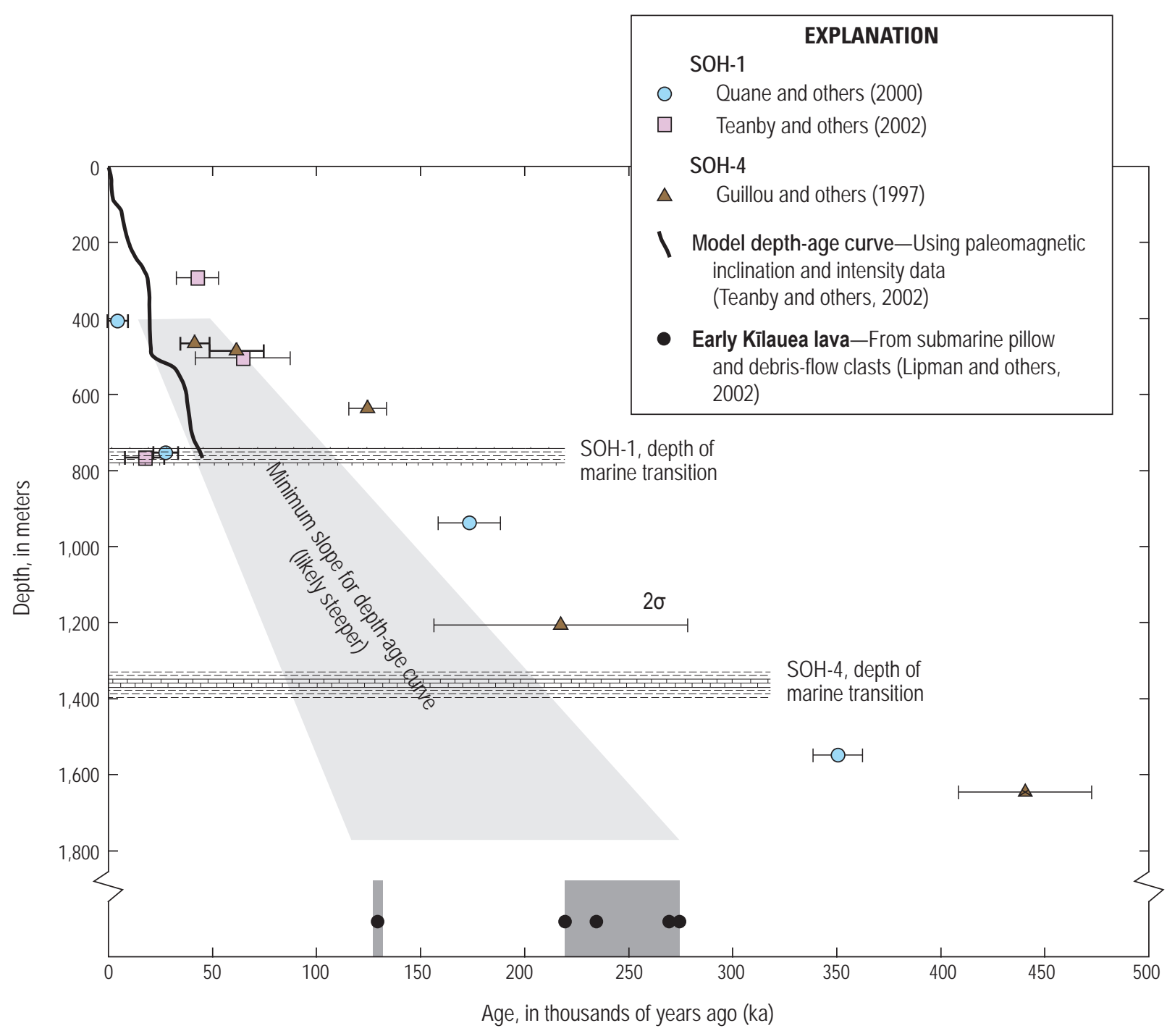

Figure 38. Radiometric ages from early alkalic volcanic rocks on Kīlauea's submarine flank (Lipman and others, 2002) and from tholeitic lava in SOH-1 and SOH-4 drill holes (Guillou and others, 1997; Quane and others, 2000; Teanby and others, 2002). Early Kīlauea submarine ages were reported without analytical error and are shown here as dots; other ages shown with $2 \sigma$ analytical error. Depth-age curve based on inclination reversals seen in drill core samples and correlation with worldwide geomagnetic data (from Teanby and others, 2002). Shaded area showing minimum slope for depth-age curve is fixed by shallowest possible depth for the early Kïlauea ages, which are at least as deep as, and more likely deeper than, base of holes. Depth of the stratigraphic boundary marking transition from subaerial to submarine environment of emplacement (marine transition) in SOH-1 and SOH-4 from Trusdell and others (1999 and 1992, respectively). 


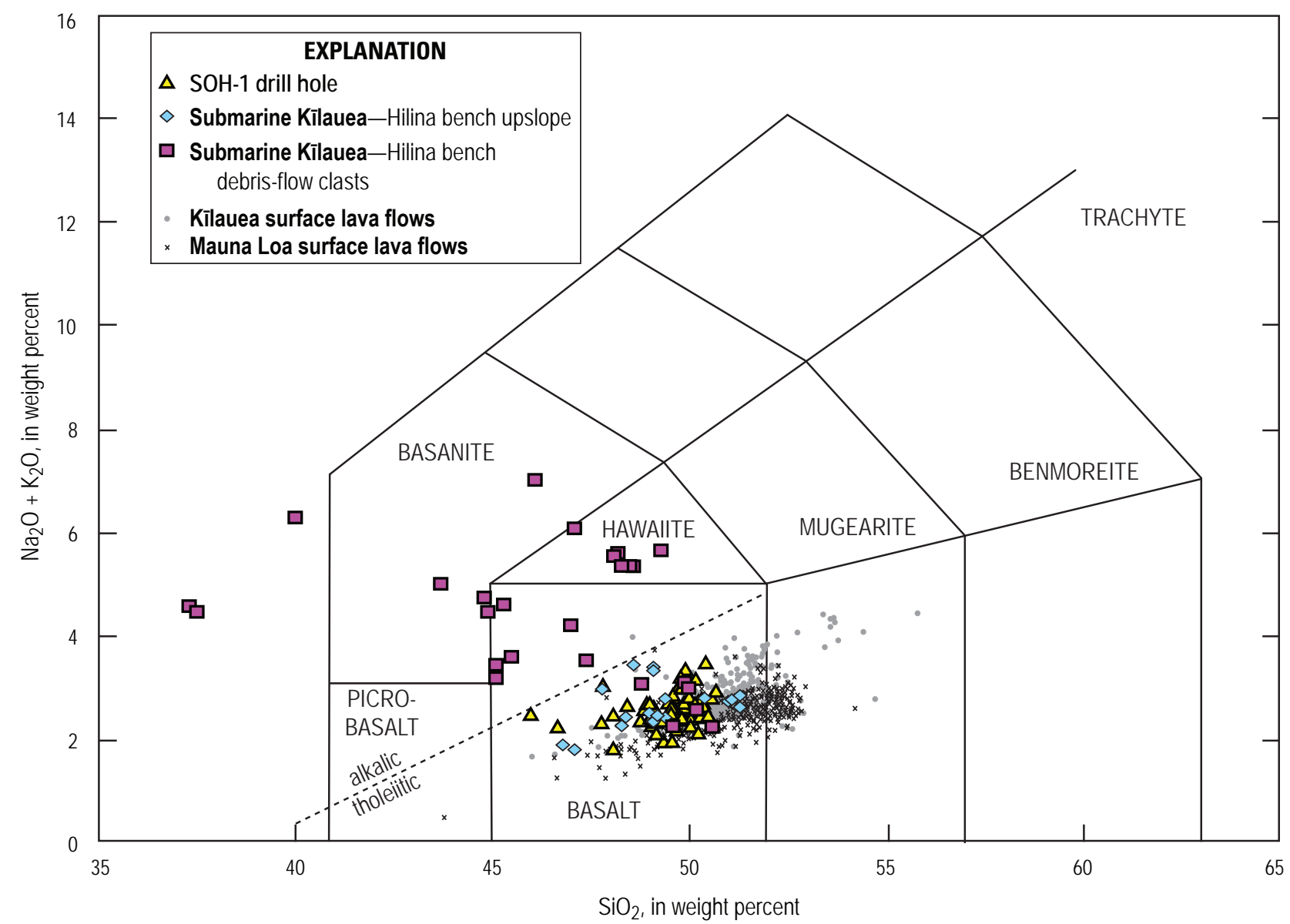

Figure 39. Alkali-silica $\left(\mathrm{Na}_{2} \mathrm{O}+\mathrm{K}_{2} \mathrm{O}\right.$ versus $\mathrm{SiO}_{2}$ ) diagram for analyzed rocks from Kīlauea Volcano sampled in $\mathrm{SOH}-1$ drill hole and offshore submarine setting (Sisson and others, 2002). Grid fields labeled for those commonly used in Hawaiian islands; grid boundaries and Mauna Loa-Kīlauea data (small black x and gray dot symbols) referenced in figure 2 caption. Data for Kīlauea's and Mauna Loa's subaerially exposed lava from Wolfe and Morris (1996b).

of basaltic ash (Pāhala Ash of many workers), and (3) the capping Puna Basalt (fig. 29). The Hilina Basalt is composed of tholeiitic lava flows thicker than $300 \mathrm{~m}$ in aggregate where exposed in fault escarpments along Kīlauea's south flank. Tephra-fall deposits are scattered within the sequence of Hilina lava flows, and a few have been assigned member status (for example, Easton, 1987). None of these individual ash beds is sufficiently thick to show on our map. Consequently, none is depicted in our GIS map database.

The base of the exposed lava-flow sequence was estimated to be about $100 \mathrm{ka}$ in age by Easton (1987), who calculated a stratigraphic accumulation rate of about $2.3 \mathrm{~m}$ per $1,000 \mathrm{yr}$ for a 17-m-thick section of the overlying Puna Basalt at Nanahu arroyo, a site where several radiocarbon ages were obtained (fig. 40). A slightly lower rate, about $1.93 \pm 0.08 \mathrm{~m}$ per $1,000 \mathrm{yr}$, is obtained if the radiocarbon ages are first calibrated to sidereal years (table 2). But the Nanahu exposure lies within an area periodically sheltered from summit-derived lava flows by uplift along the Koa'e fault system, so its accumulation rate during Puna time (past 16,000 yr) is likely nonrepresentative. Radiocarbon ages of 28.3 and $43 \mathrm{ka}$ from charcoal beneath lava flows within the Hilina Basalt (D.A. Clague, data reported by Riley and others, 1999) and the likely occurrence of the Mono Lake (35 ka) and Laschamp
(40 ka) geomagnetic excursions in the Hilina section (data of Riley and others, 1999, interpreted by Teanby and others, 2002) indicate accumulation of the Hilina Basalt at a rate about $6 \mathrm{~m}$ per 1,000 yr. This rate is in the range of the rate 7.8-8.6 $( \pm 3.1) \mathrm{m}$ per 1,000 yr that was calculated for Mauna Kea's shield-stage growth on the basis of radiometric ages from the Hilo deep drill hole (Sharp and others, 1996; Sharp and Renne, 2005). Thus we estimate that exposed Hilina lava flows are no older than about 70,000-50,000 yr (at rate $6 \mathrm{~m}$ per 1,000 yr).

The capping Puna Basalt dominates the surface of Kîlauea Volcano. The Puna Basalt includes latest Pleistocene strata, as judged from ages at its base that range from about $16,290 \pm 400 \mathrm{cal}$ yr B.P. $\left(13,675 \pm 50{ }^{14} \mathrm{C}\right.$ yr B.P.) to $12,240 \pm 480$ cal yr B.P. $\left(10,290 \pm 35{ }^{14}\right.$ C yr B.P; table 2$)$. But the older part of the sequence is difficult to show at the scale of this map. Indeed, the oldest Puna Basalt is grouped with unit Qp2, owing to its exposure only in cliffy sections along Hilina Pali (fig. 41). A single cinder cone, Puehu, is the only feature mapped as the lowest unit in the Puna Basalt, Qp1o (fig. 29); it lies isolated among younger Mauna Loa lava flows near Punalu'u. Similarly restricted in areal extent is unit Qp1y, which encompasses a fissure vent and lava flows near Pāhala (sheet 5). 
Figure 40. Photograph showing exposure of well-dated Puna Basalt sequence and underlying thick tephra deposits (Pāhala Ash), Nanahu arroyo. Thickness measured by total-station tacheometer in 2004. See table 2 for calibrated ages, geographic coordinates, and sources of data.

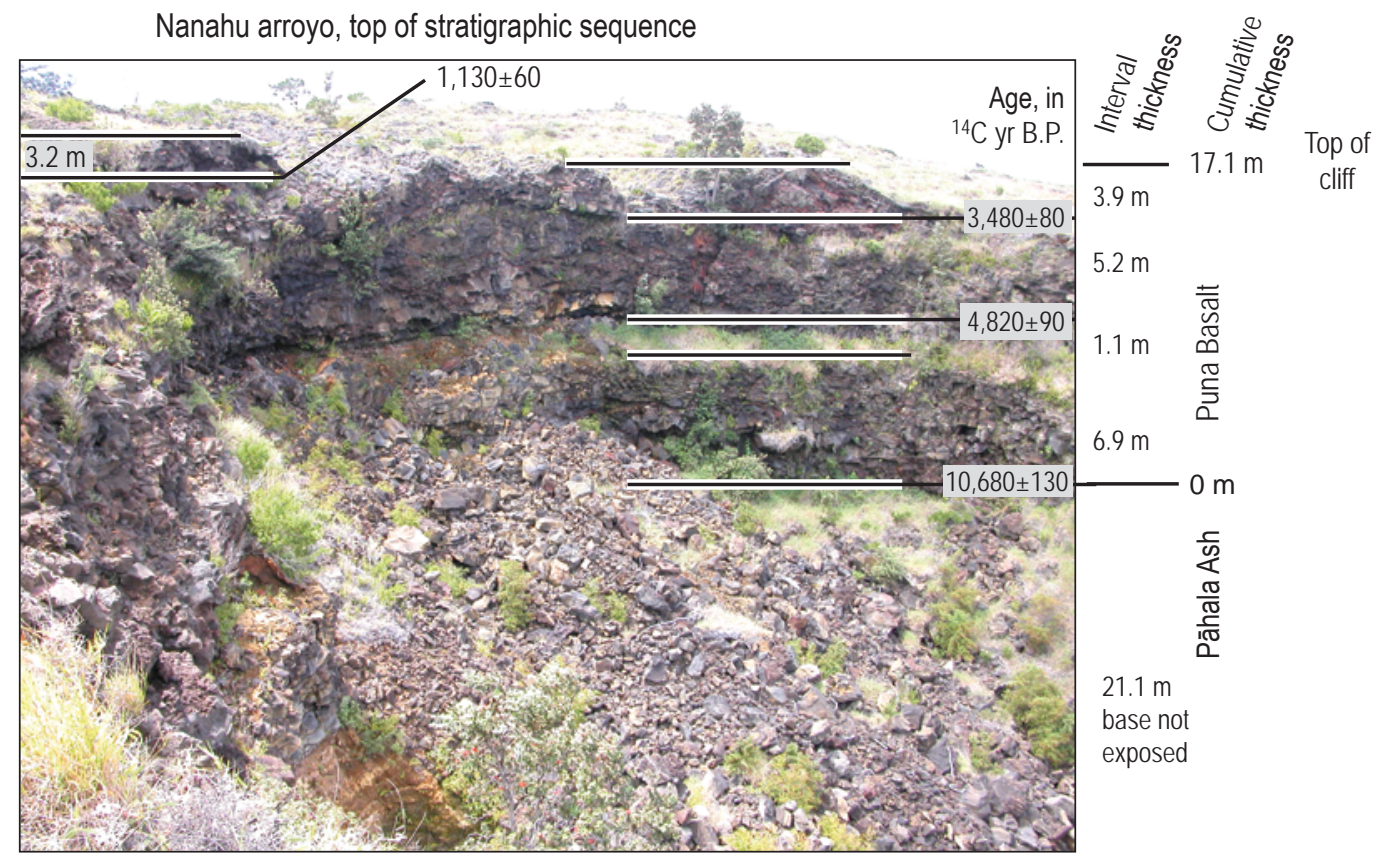

Table 2. Radiocarbon ages to determine rate of stratigraphic accumulation and age at base of Puna Basalt in Hilina Pali, Killauea Volcano, Hawai'i.

[New ages, referable to sheet 5 of this map, by John P. McGeehin, U.S. Geological Survey. Ages calibrated to sidereal years at $2 \sigma$ confidence using Calib 5.0 .1 (2005) software. Oldest age, which dates lava flow near base of thick tephra deposits (Pāhala Ash) that underlie Puna Basalt, is beyond calibration range (older than about $21,000{ }^{14} \mathrm{C}$ yr B.P.) and was not used for accumulation rate calculations. Arroyo names from Easton (1987). Only lab numbers were reported by Rubin and others (1987). Geographic coordinates in WGS84]

\begin{tabular}{|c|c|c|c|c|c|}
\hline Age, ${ }^{14} \mathrm{C}$ yr B.P. & Age, calibrated yr B.P. & Probability & Sample No. & Lab No. & Reference \\
\hline \multicolumn{6}{|c|}{$\begin{array}{c}\text { Nanahu arroyo } \\
55^{\circ} 18.1788^{\prime} \text { W. } 19^{\circ} 17.8980^{\prime} \text { N. Ka'ū }\end{array}$} \\
\hline \multirow[t]{2}{*}{$1,130 \pm 60$} & $930-1,178$ & 0.995 & - & W3827 & Rubin and others, $1987^{\dagger}$ \\
\hline & $1,215-1,221$ & 0.005 & & & \\
\hline $3,480 \pm 80$ & $3,561-3,973$ & 1.000 & - & W3831 & Rubin and others, $1987^{\dagger}$ \\
\hline \multirow[t]{2}{*}{$4,820 \pm 90$} & $5,321-5,421$ & 0.166 & - & W3798 & Rubin and others, $1987^{\dagger}$ \\
\hline & $5,437-5,732$ & 0.834 & & & \\
\hline $10,680 \pm 130$ & $12,237-12,320$ & 0.028 & - & W3809 & Rubin and others, $1987^{\dagger}$ \\
\hline Base of Puna Basalt & $12,344-12,902$ & 0.972 & & & \\
\hline \multicolumn{6}{|c|}{$\begin{array}{c}\text { Unnamed crease } \\
.9326^{\prime} \text { W. } 19^{\circ} 17.3475^{\prime} \text { N. Ka'ú D }\end{array}$} \\
\hline $10,290 \pm 35$ & $11,760-11,820$ & 0.072 & S03-KSW251 & WW4439 & This map \\
\hline \multirow[t]{4}{*}{ Base of Puna Basalt } & $11,859-12,379$ & 0.902 & & & \\
\hline & $12,508-12,556$ & 0.011 & & & \\
\hline & $12,627-12,686$ & 0.012 & & & \\
\hline & $12,709-12,719$ & 0.002 & & & \\
\hline \multicolumn{6}{|c|}{$\begin{array}{r}\text { Pohakaa Arroyo } \\
55^{\circ} 19.8282^{\prime} \text { W. } 19^{\circ} 16.5487^{\prime} \text { N. Kaūu }\end{array}$} \\
\hline $13,675 \pm 50$ & $15,939-16,691$ & 1.000 & S01-KSW8 & WW4118 & This map \\
\hline \multicolumn{6}{|l|}{ Base of Puna Basalt } \\
\hline $\begin{array}{c}30,990 \pm 250 \\
\text { near base Pāhala Ash }\end{array}$ & N/A & N/A & S01-KSW7 & WW4113 & This map \\
\hline
\end{tabular}

\footnotetext{
${ }^{\dagger}$ Reported location in error. Revised here from J.P. Lockwood (USGS, written commun., 2002).
} 

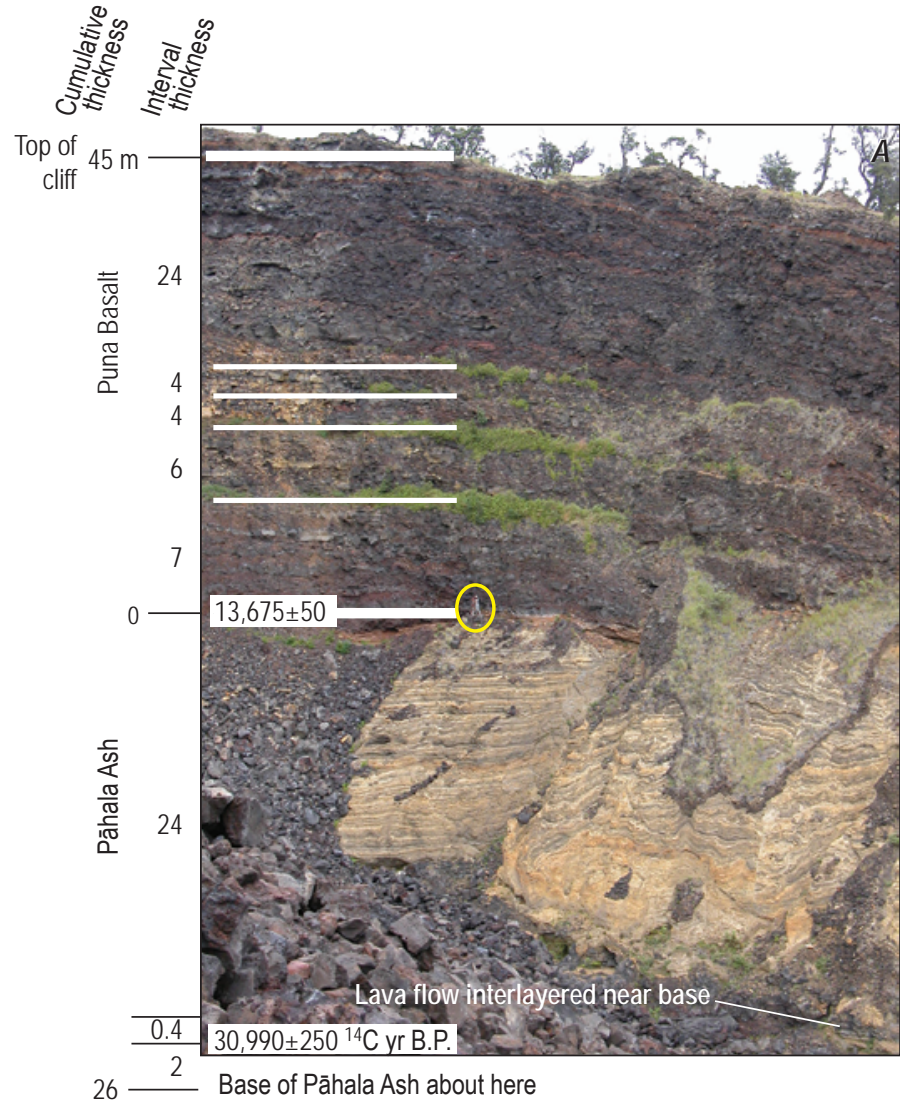

Lava flows younger than 1,500 years coat 90 percent of the volcano (fig. 35). The relative ease of distinguishing and mapping these flows has yielded a geologic map more detailed than elsewhere along the island chain (sheet 5; fig. 35). Also, many of Kinlauea's flows tend to be less extensive than those erupted at nearby Mauna Loa, where high lava production rates create areally extensive sheets of pāhoehoe and ' $a$ 'ā. Somewhat anomalous for Kîlauea's lava distribution pattern is the north flank of its East Rift Zone, which appears devoid of the detail found elsewhere on the volcano (fig. 35). This result is not a consequence of mapping hampered by the windward slope's high rainfall and dense vegetation but results instead from the emplacement of a single sequence of lava flows, the 'Ailā'au flows of the Puna Basalt (unit Qp4). These tube-fed flows spread from a small shield just east of the volcano's summit during a 50-yr period, mainly in the first half of the 15th century (A.D. 1410-1460), just before the development of Kîlauea Caldera (Clague and others, 1999).

The youngest lava of the Puna Basalt was emplaced in 2018 during Kîlauea's eruptions at the summit and lower East Rift Zone, a destructive end to the 35-year-long eruption of $\mathrm{Pu}^{\prime} \mathrm{u}$ ' $\overline{\mathrm{O}}^{`} \overline{\mathrm{o}}$ and a draining of the 10 -year-old lava lake within Halema'uma'u Crater (for example, Neal and others, 2019). Although these latest changes occurred late in the publication process of this map, we took advantage of the eruptive lull to update an earlier depiction (Sherrod and others, 2007b) and have included the 2018 flows in unit Qp5.

Though better known for its effusive eruptions, Kīlauea also ranks as an explosive volcano (Mastin and others, 1999).

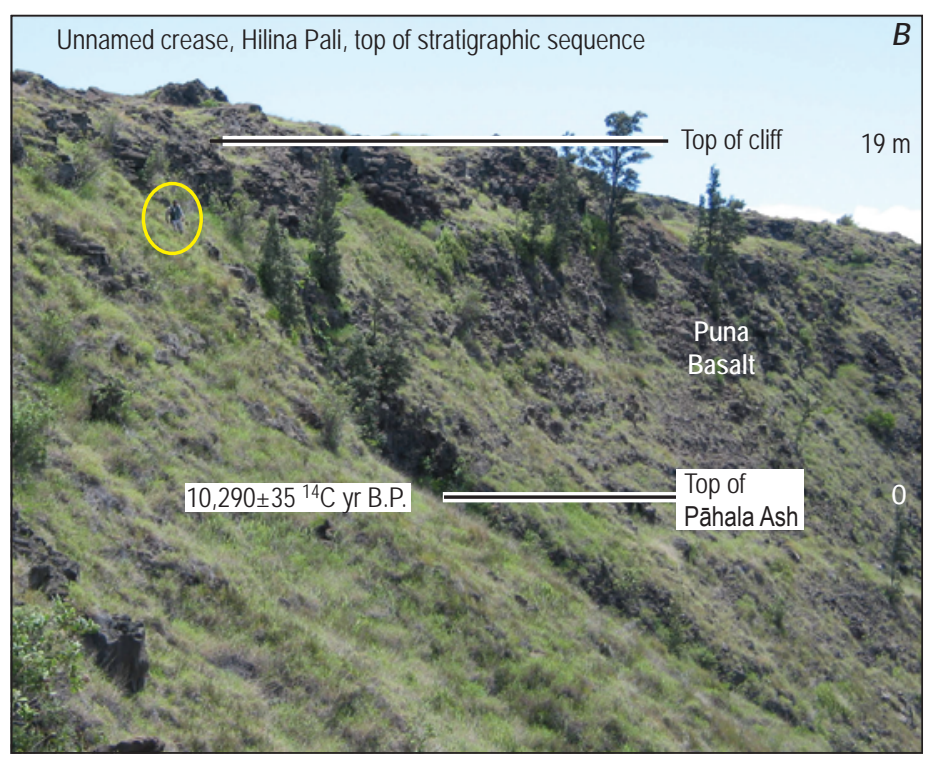

Figure 41. Photographs showing exposed base of Puna Basalt in Hilina Pali. Thickness, measured by total-station tacheometer in 2004, is rounded to nearest meter owing to variations along depositional surfaces that render more precise reporting meaningless. See table 2 for calibrated ages, geographic coordinates, and sources of data. $A$, Pohakaa Arroyo; T. Orr, surveyor; rodwoman for scale (circled). $B$, Unnamed crease; J.P. Kauahikaua, surveyor; rodman for scale (circled).

Tephra deposits in the stratigraphic record indicate a frequency of large explosive events that rivals that of Mount St. Helens, State of Washington (Swanson and others, 2002; Swanson and others, 2014). The summit of the volcano is mantled with thick tephra known as the Keanakāko'i Ash Member (a tephra sequence in the Puna Basalt, unit Qpa4y; see McPhie and others, 1990), which accumulated during a series of explosive eruptions spanning the time from about A.D. 1500 to 1790 (Swanson and others, 2004; Swanson and others, 2012). These deposits had been thought to be emplaced about A.D. 1790 and were thus shown slightly younger on previous renditions of Hawai'i Island geologic maps (Wolfe and Morris, 1996a; Trusdell and others, 2006). Another extensive deposit, the Uwēkahuna Ash Member and its upper part, the Kulanaokuaiki tephra (Fiske and others, 2009), is in the range 2,500-1,000 yr old (D.A. Swanson, written commun., 2006). Older, late Pleistocene tephra on Kîlauea is exposed chiefly near and at the top of the Hilina Basalt but is included within a regionally distributed tephra unit (Qt) owing to the uncertainty in assigning the tephra to specific volcanic sources.

Kīlauea's Hilina fault system (fig. 28), a prominent south-flank structure, has the greatest offset of any subaerially exposed faults within the island chain. The faults are highly active, with long-term vertical offset ranging from 2 to $20 \mathrm{~mm}$ per year along the system (Cannon and Bürgman, 2001). Physiographic relief is about $500 \mathrm{~m}$, and cross sections suggest separation as great as $670 \mathrm{~m}$ near Keanabihopa (Walker, 1969). These faults may penetrate to a detachment fault at or below the ocean floor-volcano boundary (for example, Lipman and 
others, 1985); or they may be shallow-rooted listric faults that flatten at depth within the volcanic pile (Swanson and others, 1976; Riley and others, 1999; Cannon and Bürgman, 2001).

The back-rotation of strata as might occur along listric faults was depicted on Walker's (1969) map. It has been corroborated independently by using paleomagnetic directions of strata in tilted and nontilted sequences (Riley and others, 1999). The rapidity of strain accumulation along the Hilina fault system led Swanson and others (1976) to anticipate the likelihood of a major earthquake - a forecast fulfilled when a magnitude 7.2 earthquake struck the volcano's south flank in November 1975, just 15 months after Swanson and his colleagues had submitted their paper for publication.

Our map depicts the Hilina and other fault systems of Kîlauea as shown by Wolfe and Morris (1996a). We make a few small changes, however, by positioning the fault within the escarpment near Keanabihopa instead of at the escarpment's foot (fig. 42). The escarpment is gullied deeply enough that the seaward limit of the upthrown block is exposed. The geomorphic escarpment has advanced seaward beyond that limit because young lava flows mantle the slope faster than the faults can extend upward. Placing the fault at the foot of the slope, as has been done in the past, indicates escarpment retreat. Exposures in the gullies near Keanabihopa show that escarpment advance is operative. The distinction centers neither on fault occurrence nor magnitude of offset (incontestable) but instead on positional accuracy, which is improved by 100-200 $\mathrm{m}$ if our interpretation is correct.

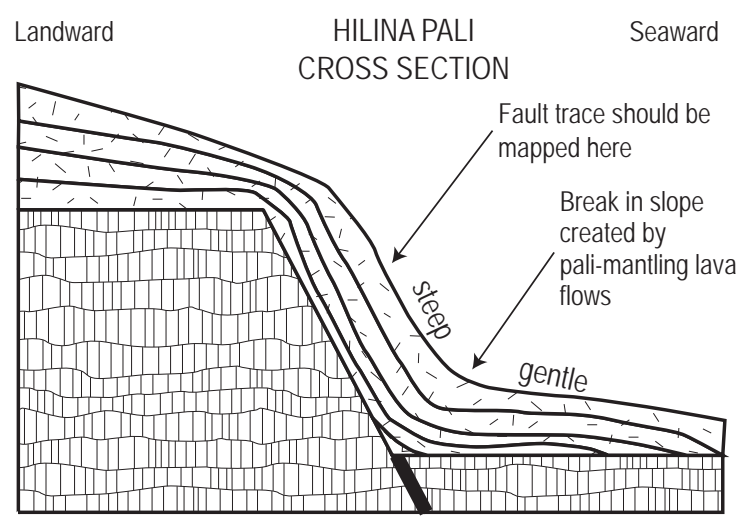

MAP VIEW

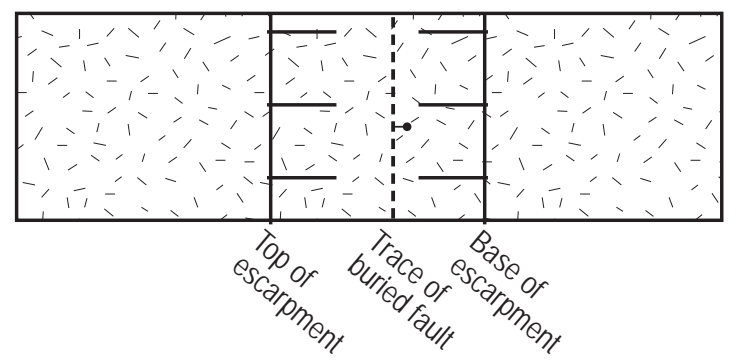

Figure 42. Diagram showing escarpment-mantling lava flows and positioning of faults. Existing geologic mapping places buried trace of fault at foot of slope, whereas fault-block exposure indicates location within the escarpment. Positional difference is $100-200 \mathrm{~m}$ in plan view for Hilina fault system near Keanabihopa, south flank of Kīlauea.

\section{DESCRIPTION OF MAP UNITS}

\section{SURFICIAL DEPOSITS}

Qf Fill (Holocene) - Manmade fill forming piers and harbor breakwaters along coastline

Qa Alluvium (Holocene and Pleistocene)-Unconsolidated deposits of silt, sand, and gravel along streams and in valley bottoms. In some areas, grades upslope to talus and colluvium (unit Qtc). On Mauna Kea, includes south-flank deposits at altitudes 2,000-2,600 m that were grouped simply as "slope deposits" by Wolfe and Morris (1996a). Where information is lacking, may include deposits more appropriately assigned to older alluvium (Qao) by virtue of greater consolidation or topographic settings not at grade with modern drainages

Qbd Beach deposits (Holocene) — Sand and gravel worked by surf into unconsolidated strand-line deposits along coastline. Chiefly cream-colored and calcareous in composition, derived from comminuted coral, shells, and foraminifera. Locally includes substantial stream-derived volcanic detritus ("black sand"), notably on East Moloka'i, East Maui, and Hawai'i. Also contains minor sandstone, known in Hawai‘i as beach rock. Typically forms deposits parallel to coast, in contrast to alluvium, which extends up drainages perpendicular to coast. This criterion was used to demarcate beach deposits on those islands like Kaho‘olawe where source maps showed all deposits as alluvium (unit Qa)

Qdy Younger dune deposits (Holocene)_Unconsolidated, mostly coralline sand forming eolian sheets and dunes. Found chiefly adjacent to beach deposits, but some reach inland as far as $2 \mathrm{~km}$ on $\mathrm{Ni}$ 'ihau and Kaua' $i$ and $7 \mathrm{~km}$ on western Moloka'i. As thick as $15 \mathrm{~m}$. On Kīlauea Volcano, unit comprises black glassy and lithic sand reworked downwind onto the volcano's southwest rift zone from 500-200-yr-old tephra deposits in the summit area 
Lake deposits (Holocene) — On Ni'ihau only. Exceedingly fine-grained calcareous sand blown into intermittent Halāli' $i$ Lake and washed into beach ridges by the lake. Natural lakes are rare in Hawai' $i$ and exposures of lake deposits even rarer

Qlg Lagoon deposits (Holocene)-Unconsolidated or poorly consolidated mud, silt, and sand. Found chiefly as mudflats in back-beach setting and some estuaries, where sediment from beach deposits and younger dune deposits (units Qbd and Qdy) is washed by water of brackish lagoons. May include marine marl or limey beds. On south-central Moloka'i, includes reddish-brown mud "carried into the sea as a result of overgrazing in the past 150 [now 200] years" (Stearns and Macdonald, 1947). As a consequence, the Moloka $i$ shoreline west of Kaunakakai has prograded substantially since the mapping by Stearns and Macdonald (1947), so that several nearshore areas shown on their topographic base map as ocean or mangrove swamp have now become fully emergent

Qls Landslide deposits (Holocene) - Blocks of lava flows and admixed soil that have slid from steep valley walls and sea cliffs. Some deposits incorporated preexisting volcanic ash deposits, which locally contributes high proportion of matrix, as in the Wood Valley area on south flank of Mauna Loa (Stearns and Macdonald, 1946; Wolfe and Morris, 1996a)

Talus and colluvium (Holocene) - Unconsolidated or poorly consolidated, poorly sorted silt, sand, and blocks that mantle slopes. Typically forms sheet or wedge-shaped deposits downslope from cliffy bedrock outcrops

Older dune deposits (Holocene and Pleistocene) —Lithified calcareous sand or eolianite. Forms dune fields inland of modern coastline. Ranges in lithification downsection, corresponding to deposits of increasingly older age. Youngest are typically weakly cemented cream-colored sand without capping caliche or red paleosol (Hearty and others, 2000), whereas older part includes eolian limestone in which pore space is completely replaced by calcite cement and individual sand grains have lost much original texture (Blay and Longman, 2001). On O'ahu these deposits, encompassing 700 ha, have been assigned to the Bellows Field Formation of Lum and Stearns (1970) and Stearns (1970). On Kaua'i, deposits exceed 28 m thickness and are mapped as the Māhā'ulepū Formation of Blay and Longman (2001). Most extensive is the 2,000-ha dune field that mantles the isthmus between West and East Maui, where dune-sand thickness is as great as 10-12 m. Holocene age assignment for youngest part stems from shells and bird bones that yielded radiocarbon ages roughly from 6,750 to $4,700{ }^{14} \mathrm{C}$ yr B.P. (for example, Hearty and others, 2000). A minimum age for the oldest part on Kaua'i was obtained by dating an interbedded lava flow of the Kōloa Volcanics, which yielded a ${ }^{40} \mathrm{Ar} /{ }^{39} \mathrm{Ar}$ age of $375 \pm 4 \mathrm{ka}$ (Hearty and others, 2005)

Tephra (Pleistocene) —Ash deposits, commonly well sorted and well bedded. Includes primary and reworked tephra. Windblown glassy tephra on $\mathrm{Ni}^{\text {' }}$ ihau was derived from Lehua cone (in unit QTekt) and forms both primary and reworked deposits (Stearns, 1947). This ash, which weathers into tan powdery soil, is younger than about $0.4 \mathrm{Ma}$ on basis of its position above lava flows of Ki'eki'e Basalt with ages $0.40 \pm 0.14$ and $0.47 \pm 0.06 \mathrm{Ma}$ (table 1). On Lāna'i, includes four small accumulations described as tuffaceous sandstone (Stearns, 1940a). These deposits, on southeast side of island, may have originated by downwind drift of ash from Haleakalā. Low on west flank of Mauna Kea (Island of Hawai $i$ i), comprises unconsolidated, cross bedded, very fine grained to fine grained dune sand and loess blankets interpreted as deposits of wind-reworked ash derived from eruptions at vents of the Laupāhoehoe Volcanics (units Qlcy, Qlc, Qlbc) (Wolfe and Morris, 1996a; Porter, 1997). Deeply weathered elsewhere on Island of Hawai'i where encompassing the "Pāhala Ash," a stratigraphic name applied to both primary and reworked tephra-fall deposits that originated from Kīlauea, Mauna Loa, Mauna Kea, and perhaps Kohala volcanoes (Wolfe and Morris, 1996a). Younger tephra of Kīlauea has been mapped as units within encompassing volcanic formations; for example, Keanakāko'i Ash Member is labeled as ash beds of age 500 to $200 \mathrm{yr}$ within the Puna Basalt (unit Qpa4). So too for deposits on other islands; for example, widespread ash of the Hāna Volcanics that mantles the summit crater and southwest rift zone of Haleakalā Crater is contained within that formation (unit Qhnt)

Qao Older alluvium (Pleistocene) — Consolidated sand and gravel, some of it sufficiently lithified to warrant the designation "conglomerate." Chiefly well rounded and moderately sorted, but includes minor, poorly sorted colluvial deposits. Forms terrace deposits and thick valley fills now being incised by modern drainages. Less commonly found mantling ridges, as on western Moloka'i. Similar sedimentary strata on Kaua'i and O`ahu, not widespread, are found interbedded with Pliocene volcanic rocks and customarily mapped as sedimentary members within associated volcanic formations there laminated lagoonal limestone. Reefs consist of coral heads and coralline algae cemented by a lime 
matrix (Stearns and Vaksvik, 1935, p. 169). Exposed subaerially on O`ahu only, although similar deposits are found as active and extinct submarine reefs that ring all the islands

Qcbc Calcareous breccia and conglomerate (Pleistocene)-Poorly to moderately sorted sedimentary deposits of marine provenance, as inferred from the presence of coralline detritus. Deposits on Lāna' $i$, which were subsequently assigned to the Hulopo“e Gravel (Moore and Moore, 1984) were described thusly: calcareous conglomerate consisting of subangular and angular lava rock, pebbles, and cobbles in a matrix of coral, coralline algae, and shells, or their weathered products (Stearns, 1940a, p. 52 ). Found on the south and southwest sides of the island at altitudes mostly below $170 \mathrm{~m} \mathrm{(550}$ ft) (Stearns, 1940a), these deposits emplaced during one or several events between about 137 and $105 \mathrm{ka}$, on basis of ages from coral fragments in deposits and estimated age of the 'A $\mathrm{Alika} 2$ Slide (Moore and Moore, 1988; Rubin and others, 2000; McMurtry and others, 1999). Two sites at higher altitude were described, including crevice-filling fossiliferous marine limestone at $326 \mathrm{~m}$ (1069 $\mathrm{ft}$ ) (Stearns, 1938). Moloka'i deposits, which extend $2 \mathrm{~km}$ inland and to altitudes as high as $72 \mathrm{~m}$, have a matrix of sandy lime mud cemented with calcite (Moore and others, 1994). Their carbonate clast component is mostly branching coral and coralline algae, with lesser gastropod shells, echinoid spines, and carbonate mud rip-up clasts, whereas the basaltic rock clasts range from angular to subrounded (A.L. Moore, 2000). On Ni'ihau, two occurrences of fossiliferous limestone are shown by an $\times$ symbol, mimicking the style on the source map (Stearns, 1947)

[In the following descriptions, many geologic notes for island stratigraphic features are drawn directly from bulletins of the Hawai'i hydrography publication series, and separate headnotes for each island's formations indicate the specific reference]

\section{VOLCANIC AND INTRUSIVE ROCKS ON THE ISLAND OF NI'IHAU}

[Bracketed page numbers refer to Stearns (1947) and Macdonald (1947), which are the chief source for description of $\mathrm{Ni}$ 'ihau geologic map units]

\section{NI'IHAU VOLCANO}

Ki‘eki‘e Basalt (Pleistocene)_-Moderately porphyritic and lesser nonporphyritic alkalic basalt (Langenheim and Clague, 1987). Olivine, less than $1.5 \mathrm{~mm}$ across, is generally the only phenocryst [p. 46]. Some samples have sufficient olivine phenocrysts to be described as transitional to picrite [p. 49]. Commonly overlain by as much as $1 \mathrm{~m}$ of red lateritic soil [p. 22]. Thickness above sea level ranges from 6 to $90 \mathrm{~m}$, but base of thicker sections not exposed because unit buries submarine bench $100 \mathrm{~m}$ deep [p. 19]. Fourteen radiometric ages range from about 2.28 to $0.35 \mathrm{Ma}$. Divided into:

Qekl Lava flows - Pāhoehoe, commonly massive and nearly horizontal, in contrast to the thin-bedded flows in the Pānī'au Volcanics [p. 14]. One 'a'ā flow was erupted from the Pu'ulehua cone, $1.3 \mathrm{~km}$ east of Nonopapa

Qekv

Qekt

Vent deposits - Thin-bedded, highly vesicular scoria, commonly with spatter at the summit

Tuff-Well-bedded vitric-lithic tuff, now mostly palagonitic, and tuffaceous breccia containing blocks of older tuff, lava, and reef limestone. Forms cones of Kawaihoa vent at southern tip of Ni 'ihau, and on Lehua island $1 \mathrm{~km}$ north of $\mathrm{Ni}$ 'ihau. Upper parts of cones contain subaerially deposited consolidated ash. Thinner deposits elsewhere on northern Ni'ihau, the larger two at mouth of Keanauhi Valley and north edge of island. Geographic relation of these thinner deposits to vent location unknown

Pān̄̄'au Basalt (Pliocene and Miocene) —Chiefly tholeiitic basalt. Aphyric to moderately porphyritic, with olivine phenocrysts $1-5 \mathrm{~mm}$ and sporadic augite to $4 \mathrm{~mm}$ [p. 42]. Total exposed thickness $390 \mathrm{~m}$. Radiometric ages range from about 6.30 to $4.68 \mathrm{Ma}$ (table 1). The large analytical error associated with the oldest age and the lack of other ages older than about 5.54 Ma suggests that the exposed sequence is entirely younger than $6 \mathrm{Ma}$. Vent marked by plug at Kā'eo was retained in the Pāni' au Basalt by Langenheim and Clague (1987) but described by them as belonging to postshield-stage volcanism, on the basis of unpublished chemical analyses. Two samples from that plug yielded ages of $4.67 \pm 0.08$ and $5.15 \pm 0.11 \mathrm{Ma}$ (table 1 ), indistinguishable from ages obtained elsewhere in the Pānī'au. No lava flows of postshield origin have been mapped separately. Divided into:

Tpl Lava flows - Thin-bedded, vesicular ' $a$ 'ā and pāhoehoe [p. 18], tholeiitic in composition. Includes a few beds of altered vitric basaltic tuff, the thickest of which is $1.5 \mathrm{~m}$ and traceable for $3 \mathrm{~km}$ [p. 18]

Tpi Intrusive rocks_-Dikes $0.2-5 \mathrm{~m}$ wide. Some are vesicular, but most are dense and cross jointed [p. 18]. Two small plugs mapped near central eastern tip of island and another at Kā'eo. Kā'eo plug has alkalic basalt composition 


\section{VOLCANIC AND INTRUSIVE ROCKS ON THE ISLAND OF KAUA`I}

[Bracketed page numbers refer to Macdonald and others (1960), which is the chief source for description of Kaua' $\mathrm{i}$ geologic map units]

\section{KAUA'I VOLCANO}

Kōloa Volcanics (Pleistocene and Pliocene)—Slightly porphyritic and aphyric basanite. Olivine typically is only phenocryst and is smaller than $2 \mathrm{~mm}$ across, but clinopyroxene is reported from some localities (Reiners and others, 1999). Unit found chiefly in unconformable contact with underlying volcanic units. Thickness in most exposures rarely exceeds $240 \mathrm{~m}$. A reported "exposed thickness" of $640 \mathrm{~m} \mathrm{(2,100} \mathrm{ft)} \mathrm{in} \mathrm{east} \mathrm{wall} \mathrm{of} \mathrm{Hanalei} \mathrm{River} \mathrm{valley} \mathrm{[p.} \mathrm{53]} \mathrm{must} \mathrm{be} \mathrm{in} \mathrm{error,} \mathrm{since} \mathrm{topographic}$ relief there is no greater than $280 \mathrm{~m}$ (920 ft). Thickness in Līhu'e basin is at least $270 \mathrm{~m}$ in Northeast Kilohana monitoring well (fig. 8, well NEK) and may exceed $300 \mathrm{~m}$ in Hanamā'ulu monitoring well (fig. 8, well H) if the lower $36 \mathrm{~m}$ of alkali basalt there is part of the unit. Includes sparse dikes and plugs. Sedimentary interbeds mapped separately in the Palikea Breccia Member of the unit. Divided into:

QTkol Lava flows - 'A' 'à and lesser pāhoehoe [p. 60]. Shown queried is patch of lava at $600 \mathrm{~m}$ altitude in Lumaha'i River, where correlation is from air-photo interpretation [p. 53]

QTkov

QTkot

Vent deposits - Cinder and spatter that form cones. Some rest on small lava shields [p. 68-70]

Palagonitic tuff - Gray to brown palagonitized vitric ash with lesser bombs and bomb fragments of basanitic lava. Contains blocks as large as $0.5 \mathrm{~m}$ of lava and reef limestone fragments. Forms large near-shore vent of Kīlauea Point, characteristic of eruptions that encountered near-surface water [p. 70-71]

QTkoa

QTkoi

Ash-Ash and cinder beds. Mapped separately only for three small exposures on northeastern part of island Intrusive rocks-Oligoclase gabbro plug upslope of Kalāheo and dike near the Manuhonohono vent west of Kōloa town. Other dikes too small to map were described [p. 74], as were the possible occurrence of two additional plugs on the basis of float found in streams

QTkop

Palikea Breccia Member-Sedimentary breccia and conglomerate, derived chiefly from erosion of the Waimea Canyon Basalt but also of Kōloa Volcanics locally. Thickness $210 \mathrm{~m}$ at type section in Palikea Ridge [p. 75]. Underlies and interbedded with lower part of the Kōloa Volcanics mainly along the east face of the Wai'ale'ale Range and in the larger valleys stemming from it. Age probably Pleistocene and Pliocene, but age span unknown. A Kōloa Volcanics lava flow with age of $2.59 \pm 0.06 \mathrm{Ma}$ (Clague and Dalrymple, 1988) in Wainiha River valley may overlie some part of the Palikea Breccia Member. Shown queried for four exposures of well-cemented conglomerate of uncertain age in Honopū and Nu'alolo Valleys along the Nāpali coast

Waimea Canyon Basalt (Pliocene and Miocene?) - Comprises all rocks of Kaua'i’s major shield volcano, including thin-bedded flank lava flows, caldera-filling lava flows, lava that fills a graben possibly related to caldera growth, sedimentary interbeds, and dikes and sparse sills. Composition chiefly tholeiitic basalt, but upper parts of caldera- and graben-filling sequence include minor hawaiite and mugearite. Age of Nāpali Member is Pliocene and late Miocene(?), on basis of radiometric ages ranging from 5.1 to $4 \mathrm{Ma}$. (Range of analytical error allows that some lava flows could be older than the 5.3-Ma Pliocene-Miocene age boundary.) Other members are Pliocene. Divided into:

Makaweli Member (Pliocene) — Tholeiitic and lesser alkalic basalt or hawaiite that fills graben adjacent to Olokele caldera. Divided into:

Twml Lava flows - 'A'ā greatly predominates over pāhoehoe [p. 46]. Slightly porphyritic, with olivine phenocrysts less than $3 \mathrm{~mm}$ across. Minor picrite and aphanitic basalt

Twmv Vent deposits - Cinders and scoria that form cone in Nāwaimaka Stream gorge. Another mapped occurrence of cinders was thought to have been washed or blown into position from Olokele caldera source [p. 46]

Twma Ash-Forms beds as thick as $1 \mathrm{~m}$ interbedded among lava flows. Several are described by Macdonald and others (1960), but only one found on their map and depicted on our rendition - a bed in the east wall of Waimea Canyon

Twmm Mokuone Breccia Beds-Comprises talus and conglomerate. Conglomerate is interbedded with lava flows of the unit. Poorly sorted talus breccia found at contact of unit with older members of the Waimea Canyon Basalt

Hā'upu Member (Pliocene) - Nearly flat-lying thick lava flows and underlying breccia. Found only in area of Hā'upu, a peak southwest of Līhu'e [p. 40-41]. Divided into: 
Lava flows - Thick vesicular olivine basalt and picrite closely resembling lava flows in the Olokele Member. No published chemical analyses. Undated but younger than underlying Nāpali Member, which in this area is probably earliest Pliocene in age

Twhb Breccia-Poorly sorted, indurated breccia. Interpreted by Macdonald and others (1960) as talus that mantles wall of a presumed Hā'upu caldera [p. 40], but may be landslide deposit related to origin of the Lìhu'e basin structural trough

Olokele Member (Pliocene) - Chiefly tholeiitic basalt lava flows except in upper part, where more alkalic flows, including sparse hawaiite and mugearite, occur. Thickness in excess of $800 \mathrm{~m}$; base nowhere exposed [p. 32]. Contact with adjacent Nāpali Member, where exposed, is along steep faults, some of which were mantled by ancient talus breccia prior to emplacement of buttressing lava flows. Divided into:

Twol Lava flows - Pāhoehoe and 'a'ā. Tend to be thicker—about $15 \mathrm{~m}$ - than lava flows in adjacent Nāpali Member, and this distinction is a criterion for defining the caldera-filling nature of the unit

Twov Vent deposits - Cinder cones (two mapped) and, at Koali hill, a small lava shield [p. 39]. Most eruptions from fissure vents that built no substantial edifices [p. 39]

Twob Breccia-Angular to subangular indurated breccia forming moderately to steeply dipping depositional wedges less than $15 \mathrm{~m}$ in thickness [p. 34-37]. Originated as caldera wall-mantling deposits; exposed today along fault that bounds the Olokele caldera

Nāpali Member (Pliocene and Miocene?)—Chiefly lava flows. Pyroclastic rocks form less than 1 percent of unit [p. 26]. Almost entirely tholeiitic basalt in composition. Divided into:

Twnl Lava flows-Pāhoehoe and 'a'ā approximately equal in abundance [p. 26]. Thin beds of ash and reddish ashy soil found between flows in many places, but beds more than a few millimeters thick are rare [p. 29]

Twnv Vent deposits - Cinder and scoria found in segments of cinder cones exposed by erosion. Includes some breccia deposits that may be pit-crater fillings [p. 30]. Some vents mapped on basis of thick dense lava thought to be crater fill; that at $\mathrm{Pu}$ 'u Ka Pele, on west rim of Waimea Canyon, is well crystallized, notably coarse-grained olivine basalt [p. 31]

Twi Intrusive rocks-Basaltic dikes and a few sills. No intrusive bodies larger than dikes have been found [p. 49]. Numerous dikes and the few sills are mapped in the Nāpali Member, but only 29 dikes were mapped in the Olokele and five in the Makaweli. Most of those in the Nāpali Member, mapped in Waimea Canyon and along Nāpali coast, trend chiefly west-southwest [p. 50], the basis for a postulated west-southwest rift zone [p. 49]. One sill at least $17 \mathrm{~m}$ thick is known from Koai'e canyon, about $0.5 \mathrm{~km}$ above confluence with Kawaiiki stream

\section{VOLCANIC AND INTRUSIVE ROCKS ON THE ISLAND OF O‘AHU}

[Bracketed page numbers refer to Stearns and Vaksvik (1935), which is the chief source for description of O'ahu geologic map units. Mapping in Wai'anae Range is newly presented here (J.M. Sinton)]

\section{KO`OLAU VOLCANO}

Honolulu Volcanics (Pleistocene) — Lava flows, vent deposits, and some wind-drifted tephra-fall deposits. Comprises a sequence of isolated, informally named lava-flow units (and their vents) or, where no lava issued, only a named vent (Stearns and Vaksvik, 1935; Winchell, 1947; Clague and Frey, 1982). Vent deposits form cones ranging from 10 to $150 \mathrm{~m}$ high. Informal names are coded in the GIS database for this map but, with two exceptions, are not described separately. Age is Pleistocene, and prior Holocene estimations are discounted, on basis of radiometric ages discussed herein. Geomorphologic evidence is consistent with assessment of an entirely Pleistocene age. Divided into:

Qokl

Deposits from Koko fissure system-Consists of:

Qokt Tuff-Gray to brown bedded crystal-lithic tuff and lapilli tuff. Includes Koko Crater, Koko Head, and Mānana Island. The alignment of tuff and spatter deposits from Koko Head to Kaupō Cove implies cogenetic eruptions along a northeast-striking fissure referred to as the Koko fissure system

Qoks Spatter-Red to brown coarse cinder and spatter

Deposits from Tantalus Peak and Sugarloaf vents-Consists of:

Qotl Lava flows

Qott Tuff-Bedded black cindery ash and lapilli. Ejected during strombolian eruptions. Blankets large area southwest of vents, likely owing to position of vents on high ridge and subsequent deflection of eruptive plume by trade winds 
Lava flows - Columnar jointed massive lava and flows typically described as 'a‘ā. Thickness generally 15-30 m where well exposed. Some flows (for example, the Kalihi, Ka'au, and Pali flows) contain lherzolite xenoliths

Qov

Qobr

Qot

QTkl

QTkt

QTkdc

QTki

QTkkl

QTkkdc

QTkkbr

Cinder vent deposits - Cinder, spatter, and ash that form cones

Breccia-Blocks of extrusive and intrusive basalt in fine-grained matrix. Typically structureless. Thought to fill throats of explosive vents (Stearns, 1939)

Tuff cone deposits - Gray to brown bedded tuff, lapilli tuff, and tuff breccia. Includes prominent vents such as Diamond Head, Punchbowl, and Salt Lake crater. Accidental lithic clasts include blocks of Ko'olau Basalt, limestone ripped from reef deposits, and, locally, xenoliths of pyroxenite, garnet pyroxenite, and lherzolite. Interpreted as hydromagmatic in origin, in contrast to cinder-vent deposits, which likely involved little entrainment of ground water or marine water during their eruptions

Ko'olau Basalt (Pleistocene and Pliocene) - Aphyric to porphyritic basalt, entirely tholeiitic in composition. Phenocrysts are olivine and plagioclase, rarely with clinopyroxene [p. 93] and orthopyroxene. Age Pliocene and Pleistocene in keeping with the definition of the Pliocene-Pleistocene boundary. Divided into:

Lava flows - 'A' ${ }^{\prime} \bar{a}$ and lesser pāhoehoe; proportions estimated to be 60 percent 'a'ā, with pāhoehoe thought to be more abundant near the crest of the Ko'olau Range [p. 93]

Vitric and lithic tuff-Vitric tuff is primary magmatic material, now fully devitrified, that originated as medial or distal fallout from small vents. Lithic tuff includes many angular rock fragments and is thought to have formed by phreatomagmatic eruptions [p. 94]. Thickness among the tuff beds commonly varies greatly over short distances and ranges from a few centimeters to $3 \mathrm{~m}$. Two occurrences of vitric tuff were recognized as erosional relicts of cinder cones underlain and overlain by

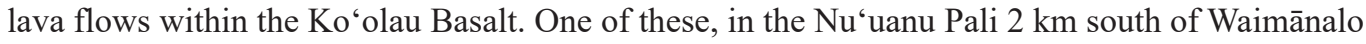
(northeast slope of $\mathrm{Pu}^{\prime} \mathrm{u}$ o Kona), lies at about $460 \mathrm{~m}$ altitude and is riddled with dikes; the other, near Kaimukī, was described only in text [p. 94]

Dike complex - Zone of abundant diking, corresponding to the denuded main rift zone of the Ko'olau volcano [p. 95]. Dikes constitute more than 40 percent of exposed rock over much of area, at expense of lava flows (unit QTkl) (Walker, 1987). Locally forms a sheeted complex where dikes have split existing dikes or intruded along their margins to create essentially 100 percent of exposed rock

Intrusive rocks-Dikes similar in composition to lava flows (unit QTkl). Width ranges from a few centimeters to $3.6 \mathrm{~m}$ but averages $0.6-1.5 \mathrm{~m}$. Mapped chiefly to indicate strays that lie outside dike complex [p. 97]; some shown in the dike complex give sense of average trend, as depicted on source map of Stearns (1939). Across the Ko'olau Range, northwest-striking dikes predominate, defining the structural grain of the volcano's principal rift zone. A secondary minor trend S. $30^{\circ} \mathrm{W}$. may be inferred from dikes in the head of Pālolo Valley and may indicate a secondary rift zone of that orientation [p. 97]

Kailua Member-Amygdaloidal basaltic lava flows and feeder dikes. Was once thought part of separate volcano that predated the Ko'olau, but later recognized as highly altered rocks of a caldera complex in the core of the Ko'olau volcano (Stearns, 1940c, p. 49). Divided into:

Lava flows - 'A' $\bar{a}$ and pāhoehoe. Joints and vesicles filled with quartz, zeolite, and other secondary minerals. Clinker in 'a'ā lava has been cemented into hard breccia [p. 88].

Dike complex within Kailua Member-Similar to dikes of the Ko'olau dike complex (unit QTkdc), from which they differ not so much in age as in extent of hydrothermal alteration (Stearns, 1940c, p. 49). Retained on this geologic map because the extent of the Kailua caldera is commonly drawn on the basis of the extent of the mapped dike complex and also because the alteration has greatly reduced the unit's permeability, which likely has important groundwater implications. May include Pleistocene rocks owing to intrusive nature for much of sequence

Breccia deposits-Angular to subangular basalt clasts in a fragmental matrix. Cemented and highly zeolitized; found in the eroded core of the Ko'olau volcano. Interpreted as deposits that fill pit craters associated with an ancient caldera [p. 97]

\section{WAI'ANAE VOLCANO}

Wai'anae Volcanics (Pliocene) - Comprises all volcanic rocks of the Wai'anae Range. Stratigraphic members assigned on basis of mapping and nomenclature of Sinton (1987), Presley and others (1997), and this map. Divided into:

Kolekole Member-Alkali basalt lava flows and cinder deposits. Phenocrysts mainly olivine 1-3 mm across (Presley and others, 1997). Commonly found are gabbro, pyroxenite, and dunite xenoliths as large as $10 \mathrm{~cm}$ across. Pyroxene and plagioclase xenocrysts are locally abundant, especially at 
Pu'uokapolei. Possesses normal-polarity magnetization throughout and is younger than about $3 \mathrm{Ma}$ (Presley and others, 1997). Divided into:

Talel

Talev

Talec

Tapl

Tapv

Takl

Takv

Takbr

Takmk

Takil

Takiv

Tall

Talv

Tai

Lava flows-' $A$ ' $\bar{a}$

Vent deposits-Cinder and spatter that form cones.

Debris flows-Poorly sorted, moderately indurated sedimentary deposits. Includes Kolekole Conglomerate of Stearns (1946), which is overlain by lava flows of Kolekole Member. Other occurrences are conglomerate cut by dikes at end of ridge south of Schofield valley and debris-flow deposits along the crest of the northern Wai'anae Range, all of which are likely to have formed before cessation of volcanic activity

Pālehua Member-Aphyric hawaiite with lesser porphyritic basalt, alkali basalt, and mugearite. Maximum thickness $250 \mathrm{~m}$, near Palikea in southern part of range. Divided into:

Lava flows - Characterized by ' $\mathrm{a}$ 'a $2-30 \mathrm{~m}$ thick with massive centers and thin rubbly tops and bases [p. 75]. Tends to form high cliffs of conspicuously light color in exposures near the top of the western slope of the Wai' anae Range (Macdonald, 1940a, p. 78)

Vent deposits - Cinder and spatter that form cones

Kamaile'unu Member-Tholeiitic and alkalic basalt and hawaiite that form a caldera-filling sequence and adjacent flanking strata. Generally possesses lower dips than underlying Lualualei Member in the central part of the range. Includes lava flows with normal- and reversed-polarity magnetization. Equivalent to middle member of Wai'anae volcanic series of Stearns and Vaksvik (1935). Age ranges from 3.5 to 3.1 Ma (McDougall, 1964; McDougall and Aziz-ur-Rahman, 1972; Doell and Dalrymple, 1973; Laj and others, 1999; and Guillou and others, 2000). Divided into:

Lava flows-Pāhoehoe and lesser ' $a$ 'āa, similar to Lualualei Member (unit Tall) but with more 'a'ā than the Lualualei. Almost always contains plagioclase phenocrysts, which are mostly lacking in the Lualualei Member

Vent deposits - Chiefly cinder

Breccia-Angular to subangular fragments of basaltic lava flows in a sedimentary sandy matrix. Generally well indurated. Interpreted as talus that accumulated against cliffs of caldera wall (Macdonald and others, 1983, p. 427) or other faults

Mauna Kūwale Rhyodacite Flow-Hornblende-biotite rhyodacite lava flow. Phenocrysts as large as $1 \mathrm{~mm}$ of plagioclase ( 20 percent), hornblende (12 percent), biotite ( 8 percent), and hypersthene (1 percent) (Macdonald, 1940a, p. 82). Weathers to conspicuous white to pink outcrops. Ranges in thickness from 40 to $110 \mathrm{~m}$

Icelandite lava flows - ' $\mathrm{A}$ ' $\bar{a}$ and blocky flows 5-15 m thick of icelandite (Al-poor, Fe-rich andesite) composition

Icelandite vent deposits - Coarse- to medium-grained scoria

Lualualei Member-Aphyric and porphyritic olivine basalt. Includes rare tuff beds distributed sporadically. All parts possess reversed-polarity magnetization and are older than 3.5 Ma (Guillou and others, 2000). Divided into:

Lava flows - Predominantly pāhoehoe, with minor 'a'a a [p. 68]. Individual flows range in thickness from 1.5 to $22 \mathrm{~m}$. Lava flows with about 50 percent olivine phenocrysts are present in $\mathrm{Pu}^{\prime} \mathrm{u}$ o Hulu Ridge and a few other places [p. 68]

Vent deposits - Partly buried cinder cone exposed in south side of $\mathrm{Pu}^{\text {'u Heleakalā }}$

Intrusive rocks - Olivine basalt dikes a few centimeters to $5 \mathrm{~m}$ thick; most are fine grained and resemble lava flows in hand sample. Microgabbroic texture characterizes a few dikes large enough to have cooled slowly (Macdonald, 1940a, p. 73). Also includes medium- to coarse-grained intrusion of plagioclase-rich diorite in Kaua'ōpu'u ridge. Comprises feeders for lava flows and vents of all four members of the Wai'anae Volcanics. Dikes in the northern part of the range oriented mainly $305^{\circ}$ and define a well-developed northwest rift zone, whereas elsewhere dike trends are more typically radial (Zbinden and Sinton, 1988)

\section{VOLCANIC AND INTRUSIVE ROCKS ON THE ISLAND OF MOLOKA`I}

[Bracketed page numbers refer to Stearns and Macdonald (1947), which is the chief source for description of East Moloka'i geologic map units. Mapping of West Moloka'i is newly presented here (J.M. Sinton)]

\section{EAST MOLOKA‘I VOLCANO}

Qppl Kalaupapa Volcanics (Pleistocene) - Porphyritic pāhoehoe lava flows that built the broad Kalaupapa Peninsula at base of the great windward cliff of East Moloka'i. Ranges in composition from tholeiitic to 
alkalic basalt (four analyses) and basanite (two analyses). Age is late or middle Pleistocene on basis of three K-Ar ages ranging from about 0.57 to $0.34 \mathrm{Ma}$ (Clague and others, 1982). Unit is mapped separately as:

Qppv Vent deposits_Low lava cone and its surmounting Kauhakō Crater and a cinder cone plastered on base of main Moloka'i escarpment

Qmv Tuff of Mokuho‘oniki cone (Pleistocene)—Palagonitic basaltic ash, spatter, sparse lava flows, and a few dikes that built Mokuho'oniki and Kanahā, two small islands $1.6 \mathrm{~km}$ off the eastern end of Moloka'i. The only petrographic description available, perhaps representative of the deposits as a whole, is for a picritic dike that contains about 30 percent olivine phenocrysts as large as $1 \mathrm{~mm}$ [p. 109]. Lithic fragments and coralliferous limestone commonly found as blocks in the bedded ash. Deposited chiefly by hydromagmatic eruptions, indicating substantial entrainment of water-probably sea water-into the shallow eruptive column. Commonly assigned an age similar to that of the Kalaupapa Volcanics [p. 109], although the unit is undated and known only to be younger than upper member of the East Moloka'i Volcanics; that is, younger than about 1.3 Ma

East Moloka‘i Volcanics (Pleistocene)_-All volcanic rocks of the East Moloka‘i topographic edifice, exclusive of Kalaupapa Peninsula. Divided into:

Upper member-Composition ranges from basanite to benmoreite, with a single trachyte dike. Nonporphyritic and porphyritic lava occur about equally [p. 100]. Phenocrysts chiefly feldspar, 1-2 mm and as much as 10 percent in abundance. Olivine much less common but where present is less than

$2 \mathrm{~mm}$ across and less than 5 percent. Upper member lacks mapped intrusive rocks. Age ranges from about 1.52 to $1.31 \mathrm{Ma}$, on basis of three K-Ar ages (McDougall, 1964) and three ${ }^{40} \mathrm{Ar} /{ }^{39} \mathrm{Ar}$ ages (Sinton and others, 2017). Consists of:

Qemul Lava flows - 'A' $\quad$ 'à ranging from 6 to $30 \mathrm{~m}$ thick. Pāhoehoe is rare [p. 100]. Flows commonly separated by ashy soil beds. Lava flows weather medium to light gray, producing a distinct light-on-dark color contrast where contact is exposed with underlying darker gray lava flows of the lower member of the East Moloka'i Volcanics

Qemuv Vent deposits-Cinder and spatter that forms bulky cones, the eruptive sites for the lava flows of the upper member. Shown queried are deposits east of Wailau, where two hills have geomorphic form of cinder cones but no exposures were found despite searching by Stearns and Macdonald (1947)

Qemud Domes_Extrusions of lava that likely piled up over vent sites. Some are found within the craters of vent deposits

Lower member-Tholeiitic and alkalic basalt. Age near top is as young as 1.52 Ma (McDougall, 1964; recalculated using modern decay constants) for a sample from the type locality along the trail to Kalaupapa Peninsula. At the east end of the island, a sample collected about $300 \mathrm{~m}$ beneath the top of the unit yielded an age of 1.75 Ma (Naughton and others, 1980). Consists of:

Qemll Lava flows - Pāhoehoe and 'a'ā of aphyric to porphyritic olivine basalt. Youngest flows include lava rich in olivine and augite phenocrysts

Qemlv Qemlcc Vent deposits-Cinder and spatter cones

Caldera complex - Thick lava flows, numerous intrusive plugs, and talus and fault breccias cut by dike swarms. Greater thickness of individual flows due to ponding, in contrast to thinner flows elsewhere in the East Moloka'i sequence. Rocks of caldera complex characterized by substantial secondary mineralization, occurring as vesicle linings and amygdules of calcite, quartz, and chalcedony, and irregular nodules of quartz and chalcedony. Many lava flows partly altered to smectitegroup clay minerals

Qemli Intrusive rocks_-Dikes, steep to vertical in inclination. Not mapped separately are stocks and plugs within the caldera complex (unit Qemlcc)

\section{WEST MOLOKA'I VOLCANO}

Wai'eli Volcanics (Pleistocene)_-Alkalic basalt and hawaiite lava flows and vent deposits. Nearly aphyric in most exposures, with sparse olivine less than $2 \mathrm{~mm}$ across. Most outcrops expose only one flow unit, thickness typically less than $10 \mathrm{~m}$ and, locally, underlying red ashy soil 0.2-1.2 m thick. In contrast, lava flows of the West Moloka'i Volcanics typically lack intervening soil horizons. Radiometric ages from four lava samples range from 1.80 to 1.73 Ma (Clague, 1987a; Sinton and others, 2017). Wai'eli Volcanics are newly recognized as products of postshield-stage volcanism on West Moloka' $i$ (Sinton and others, 2017). Their cumulative volume is less than $1 \mathrm{~km}^{3}$ as presently exposed on West Moloka'i. Includes the Mo'omomi and Ka'a units that were quarried by early Hawaiians, giving rise to the local name Kalua Ko'i (lit.: the adze pit) for the west end of West Moloka‘i. Divided into: 
Qwely Younger lava flows-Mostly ' $a$ ‘a a , all possessing reversed-polarity magnetization. Age less than 1.778 Ma, which marks the end of the next-older subchron, the Olduvai Normal-Polarity Subchron. Youngest age is poorly constrained by existing data

Qwevy Younger vent deposits-Cinder cones. Most are associated with alkalic lava flows possessing reversedpolarity magnetization

Qwelo Older lava flows - 'A' $\bar{a}$ lava with normal magnetic polarity. Distinguished from underlying normalpolarity tholeiitic lava of the West Moloka'i Volcanics on basis of chemical analyses and stratigraphic position. Erupted within the Olduvai Normal-Polarity Subchron; that is, 1.945-1.778 Ma. Oldest age may be no greater than $1.79 \pm 0.04 \mathrm{Ma}$, on the basis of ${ }^{40} \mathrm{Ar} / 39 \mathrm{Ar}$ ages from two lava flows (Sinton and others, 2017)

Qwevo Older vent deposits-Cinder cones feeding alkalic lava flows with normal magnetic polarity QTwmi Intrusive rocks (Pleistocene and Pliocene?)—Dikes

West Moloka'i Volcanics (Pleistocene and Pliocene?) - Lava flows and vent deposits of tholeiitic and, less commonly, compositionally transitional basalt. The abundance of nonporphyritic lava is unusual when compared to shield-building products from other Hawaiian volcanoes. Porphyritic lava, which forms about 30 percent of the unit, contains variable amounts of plagioclase, augite, and olivine phenocrysts. Radiometric dating is incomplete; could include strata of Pliocene age. Divided into:

Qwmly Younger lava flows (Pleistocene) - Nonvesicular ' $a$ 'a lava flows with normal-polarity magnetization. Radiometric ages and magnetic polarity indicate eruption during the Olduvai Normal-Polarity Subchron. Likely age based on radiometric ages and magnetic polarity is 1.95-1.8 Ma. Included in this unit is the 'Amikopala lava shield, about $3 \mathrm{~km}^{3}$ in volume, which hosted an important habitation site and adze quarry for early Hawaiians (Weisler, 2011)

Qwmvy Younger vent deposits (Pleistocene) - Cinder cones feeding normal-polarity tholeiitic lava flows

QTwmlo Older lava flows (Pleistocene and Pliocene?) —Pāhoehoe and 'a'ā tholeiitic basalt lava flows that form the main volcanic sequence on West Moloka'i. Notably thin bedded (less than $0.6 \mathrm{~m}$ ) at many localities. Older than Olduvai Normal-Polarity Subchron. Unit is mapped separately as:

QTwmloo Olivine-rich basalt- ' A' $\bar{a}$ lava flows with more than 15 percent olivine phenocrysts as large as about $5 \mathrm{~mm}$. Restricted to the southwest rift zone west of Hale o Lono and to Pu'u Pili on West Moloka'i's north flank

QTwmvo Older vent deposits (Pleistocene and Pliocene?)—Cinder and spatter cones associated with lava flows of units QTwmlo and QTwmloo

\section{VOLCANIC AND INTRUSIVE ROCKS ON THE ISLAND OF LĀNA'I}

[Bracketed page numbers refer to Stearns (1940a), which is the chief source for description of Lāna'i geologic map units]

\section{LĀNA'I VOLCANO}

Lāna'i Basalt (Pleistocene) — Tholeiitic basalt. Olivine phenocrysts, 1-3 mm in diameter, are found in about 40 percent of flow sequences; plagioclase is a less common phenocryst, and pyroxene phenocrysts are seen only rarely. Divided into:

QII Lava flows-Pāhoehoe and ' $a$ ' $\bar{a}$, the former more abundant in the summit areas, the latter along the periphery of the island. Individual flows range in thickness from 0.3 to $30 \mathrm{~m}$, average about $6 \mathrm{~m}$. Massive lens-shaped columnar-jointed flows seen in Kaholo Pali and cliff east of Mānele are craterfilling lava accumulations, not sills [p. 27]

QIv Vent deposits_Lava cones with subordinate amounts of spatter and cinder [p. 29]; no cones existing exclusively of cinders were found

Qler Filled craters-Pit craters originating by collapse and infilled by later lava flows. They may be marked by ponded flows, or steep, nonconformable contacts may be exposed, some with talus breccia onlapped by the infilling lava flows [p. 30-31]

Qlbr

Breccia in craters - Small patches of breccia filling eroded pit craters. Possibly related to northwest rift zone, because the unit forms a northwest-trending alignment defined by nine separate exposures along Wai'alalā Gulch, just east of the central part of the island

Qli

Intrusive rocks - Dikes, steep to vertical in orientation and ranging from 0.15 to $1.5 \mathrm{~m}$ in width. As on the source map, those dikes exposed only in sea cliffs have been extended inland to give them sufficient length to show on the map 


\section{VOLCANIC AND INTRUSIVE ROCKS ON THE ISLAND OF KAHO`OLAWE}

[Bracketed page numbers refer to two chapters in the Division of Hydrography Bulletin 6-Stearns (1940b, p.117-147) and Macdonald (1940b, p.149-173) — which are the chief sources for description of Kaho'olawe geologic map units]

\section{KAHO`OLAWE VOLCANO}

Qyvk Young volcanic rocks of Kaho'olawe (Pleistocene)—Dikes and isolated patches of cinder exposed in the wall of Kanapou Bay. Tholeiitic basalt. Some dikes cut older alluvium. One view of relative age was implied in a description of some cinder deposits, "the cinders are easily eroded and lie on such a steep cliff that they obviously could not persist long." [p. 143]. Recent dating and sparse magnetic sampling suggest an age of about 1.0-0.9 Ma (Sano and others, 2006). Considered products of rejuvenated-stage volcanism by Langenheim and Clague (1987) and Fodor and others (1992), but we find them the last gasp of late shield-postshield volcanism (Sano and others, 2006)

Kanapou Volcanics (Pleistocene) - All volcanic rocks of Kaho'olawe exclusive of the four small occurrences assigned to young volcanic rocks of Kaho'olawe (unit Qyvk). Comprises lava flows and vent deposits ranging in composition from tholeiitic basalt to hawaiite, including those that belong to the conceptual "shield" and "postshield" stages of Hawaiian volcanism. In original mapping (Stearns, 1940b), lava flow units were divided on basis of age relative to formation and filling of a caldera exposed at Kanapou Bay. Divided into:

Qnppl Postcaldera lava flows — Lava flows typically less vesicular than precaldera flows and thicker, even where not ponded. Unit is thickest where it fully filled the caldera; forms a thin cap over most of the rest of the island. Many flows are moderately porphyritic, with olivine, augite, and plagioclase, and "they form so much of the surface that one gains the impression at first that all the rocks of Kaho'olawe are augite, olivine, feldspar 'a'ā porphyries" [p. 140]. Hypersthene was reported in four of seven postcaldera samples analyzed by Macdonald [p. 156]. Considered products of postshieldstage volcanism by Langenheim and Clague (1987) and postshield- or late-shield-stage volcanism by Fodor and others (1992)

Qnppv Postcaldera vent deposits - Chiefly cinder cones, but includes lava domes or small shields of Keālialalo and Makika (shield surmounted by Moa' ula cone). The cones locally contain thin interbedded lava flows

Caldera-filling lava flows-Thickness of individual flows ranges from 3 to $60 \mathrm{~m}$. Many flows exhibit columnar jointing. Resemble precaldera lava flows petrographically but tend to be slightly coarser grained owing to greater flow thickness. Shown as fault bounded, in keeping with source maps (for example, Stearns, 1940b, his fig. 25) but may lie partly or entirely in buttress unconformity with precaldera lava flows (unit Qnpl)

Qnpct Tuff bed in caldera fill-Vitric tuff 10-15 m thick. Becomes finer in texture north and south of its midpoint. Other tuff beds in caldera fill are too thin and discontinuous to be depicted on source map (scale 1:62,500)

Qnpl Precaldera lava flows - Thin-bedded, slightly porphyritic and nonporphyritic ' $a$ ‘āa and lesser pāhoehoe [p. 160]. Olivine and plagioclase phenocrysts are widespread but not abundant; clinopyroxene phenocrysts are rare. Individual flows range in thickness from 2 to $30 \mathrm{~m}$ and average about $8 \mathrm{~m}$. Includes sparse beds of vitric tuff less than $0.3 \mathrm{~m}$ in thickness

Qnpv Precaldera vent deposits—Small lava mounds, tens of meters across, surmounted by cinder and spatter [p. 169]

Qnpi

Intrusive rocks-Dikes, steep to vertical in orientation and chiefly less than $0.5 \mathrm{~m}$ wide

\section{VOLCANIC AND INTRUSIVE ROCKS ON THE ISLAND OF MAUI}

\section{HALEAKALĀ VOLCANO}

[Bracketed page numbers refer to Stearns and Macdonald (1942). Mapping includes substantial new work presented here (Sherrod and others, 2007b)]

Hāna Volcanics (Holocene and Pleistocene) — Lava flows, vent deposits, and sparse debris-flow deposits. Aphyric lava flows predominate, but slightly to highly porphyritic rocks are common. Olivine, 1-3 $\mathrm{mm}$ in diameter, is most common phenocryst. Clinopyroxene increases in proportion in more porphyritic rocks. Scant plagioclase phenocrysts (xenocrysts?), typically as large as $1 \mathrm{~cm}$. Holocene and Pleistocene age is formally adopted herein, owing to numerous radiometric ages, the oldest of which indicate emplacement as early as $0.12 \mathrm{Ma}$ (Sherrod and others, 2003). Divided into: 
Lava flows (Holocene and Pleistocene)—Predominantly 'a'ā lava flows, with minor pāhoehoe. Shown queried where abruptly terminated for three lava-flow sequences whose downslope extent is poorly known (one each in units Qhn0 and Qhn1 on upper west flank and another in unit Qhn4 on upper northeast flank). Divided on the basis of age according to the following matrix:

\begin{tabular}{|c|c|}
\hline $\begin{array}{l}\text { Lava } \\
\text { flows }\end{array}$ & Age, years \\
\hline Qhn6 & $0-1,500$ \\
\hline Qhn5 & $1,500-3,000$ \\
\hline Qhn4 & $3,000-5,000$ \\
\hline Qhn3 & $5,000-13,000$ \\
\hline Qhn2 & $13,000-30,000$ \\
\hline Qhn1 & $30,000-50,000$ \\
\hline Qhno & $50,000-140,000$ \\
\hline
\end{tabular}

Qhnv Vent deposits (Holocene and Pleistocene) —Scoria and spatter that form vent deposits, mainly cinder cones. Not divided by age

Qhnt

Qhni

Tephra deposits (Holocene and Pleistocene)—Fallout tephra ranging from coarse to fine grained lapilli, ash, and crystals, deposited chiefly during downwind distribution from vent-building eruptions.

Includes intervening thin beds reworked by slope wash. Individual beds generally less than $5 \mathrm{~cm}$ thick, but aggregate deposits are locally thicker than $10 \mathrm{~m}$. Mapped where sufficiently extensive to blanket large areas completely; otherwise not shown separately

Intrusive rocks (Holocene and Pleistocene) - Dikes. Sparsely exposed, owing to lack of erosion into Hāna Volcanics. The eight dikes found on southwest flank of Kolekole, west of Haleakalā Crater, may be crack-filling lava that now presents a dikelike aspect as erosion proceeds. A ninth, in Haleakalā Crater, results from small fault north of Halali i $i$ i that uncovered the dike and striated its east-facing surface

Qhne

Explosion crater deposits (Pleistocene) - Sandy blanket of gray lithic lapilli and coarse ash. Surrounds two craters at 2,740 m (9,000 ft) altitude along southwest rift zone. No known relation to volcanic vent, but may have formed by heating of perched water as magma rose to feed vents farther east or west. State of preservation suggests late Pleistocene age

Qkamd Kaupō Mud Flow (Pleistocene)—Debris-flow deposits of breccia with clasts locally greater than $3 \mathrm{~m}$ across in a poorly sorted lithic-sand matrix. Older than $120 \mathrm{ka}$, the age of an overlying lava flow (in unit Qhn0). Unit is mapped separately as:

Qkamc Conglomerate-Sparse roundstone conglomeratic strata interbedded with debris-flow deposits Kula Volcanics (Pleistocene) - Aphyric to porphyritic lava flows, vent deposits, and intrusive rocks. Lower part ranges from hawaiite to mugearite with rare trachyte; upper part is more alkalic and includes basanite. Divided into:

Qkul

Qkuls

Lava flows - Chiefly ' $a$ 'ā; pāhoehoe is minor. Shown queried for lava flows of uncertain age that issued from vent at 2,800-m (9,100-ft) altitude on southwest rift zone. Unit is mapped separately as:

Summit ankaramite - Highly porphyritic 'a'ā lava flows. Informally named for exposures at and downslope from Haleakalā Visitor Center in Haleakalā National Park. Erupted from a vent now eroded but near there, judging from abundance of dikes and sills in east slope of Pāka'ao'ao. Likely youngest Kula stratum on west flank. Age $0.214 \pm 0.020 \mathrm{Ma}$ (2 $\sigma$ analytical error; Sherrod and others, 2003)

Qkuv

Vent deposits - Scoria and spatter that form cinder cones and sparse spatter ramparts. Shown queried for (1) some deposits of uncertain age assignment along upper southwest rift zone and (2) two geomorphic cones on upper northeast flank that lack exposure owing to burial by Hāna tephra deposits (unit Qhnt)

Qkui Intrusive rocks-Mainly dikes similar in composition and mineralogy to lava flows in Kula Volcanics. A few stocks are exposed in western summit area of volcano

Qmnl Honomanū Basalt (Pleistocene) - Pāhoehoe and 'a'ā lava flows. Surface exposures found along north and northeastern coast of East Maui and, near Ke'anae, upslope along canyon walls to as high as 900-m altitude. Most of exposed sequence possesses reversed-polarity magnetization. Exposures in Haleakalā Crater, mapped as Honomanū Basalt by Stearns and Macdonald (1942), are now considered part of Kula Volcanics on basis of whole-rock chemical and isotopic analyses (Macdonald and others, 1983; West and Leeman, 1987). We made similar finding for those in walls of Kīpahulu Valley, which have normal-polarity magnetization and basanitic composition 
[Bracketed page numbers refer to Stearns and Macdonald (1942), which is the chief source for description of West Maui geologic map units]

Lahaina Volcanics (Pleistocene) — Lava flows and vent deposits of basanitic composition. Aphyric to very slightly olivine phyric. Erupted from four discrete vents, two active about 0.6 Ma and another two about 0.4 Ma (Tagami and others, 2003). Divided into:

QIhl Lava flows_-Thick 'a'ā flows

QIhv Vent deposits-Cinders, spatter, and bombs

Honolua Volcanics (Pleistocene)_Lava flows, lava domes, vent deposits, and intrusive rocks. Unit is as thick as $230 \mathrm{~m}$ but averages $20 \mathrm{~m}$. Mainly benmoreite with lesser trachyte. Divided into:

Qul Lava flows_- 'A' à. Massive central parts are columnar jointed. Thickness generally ranges from 7 to $90 \mathrm{~m}$ but approaches $150 \mathrm{~m}$ thick near vents

Qud Domes-Bulbous masses of lava, mostly extrusive but including some shallow intrusive necks. (An excellent example of a bulbous dome grading down to a dike only $8 \mathrm{~m}$ wide is found about $3.6 \mathrm{~km}$ east of Olowalu [p. 179]). Concentric jointing prominent on some domes

Quv

Vent deposits - Bedded cinders similar in composition to lava flows. Some cinders surround and underlie lava domes, whereas those northwest of Olowalu have built a cone that lacks associated lava dome

Qui

Intrusive rocks-Dikes ranging in width from 2.5 to $8 \mathrm{~m}$

Wailuku Basalt (Pleistocene) — Comprises the main mass of West Maui's shield volcano, including thinbedded flank lava flows, caldera-filling lava flows, and dikes and sparse sills. Composition chiefly tholeiitic basalt, but upper part contains some alkalic basalt and minor hawaiite. Age is formally revised herein, Pleistocene, on basis of radiometric ages ranging from about 2 to $1.3 \mathrm{Ma}$ (Sherrod and others, 2007a). Divided into:

Qwl Lava flows_-Thin pāhoehoe and ' $a$ ' $\bar{a}$

Qwv

Vent deposits - Scoria and spatter of cinder cones

Qwt

Tuff_-Thin beds interspersed among lava flows, forming less than 1 percent of Wailuku Basalt [p. 163]. More numerous in upper part of lava-flow unit $(\mathrm{Qwl})$ and closer to rift zones. Generally mappable only on arid southwest side of volcano

Qwpc Pit crater deposits_Lava flows, breccia, talus, and slope wash that define the extent of collapse craters that formed along rift zones during Wailuku time. Lava flows are compositionally similar to those elsewhere in Wailuku Basalt but are found in buttress unconformity with adjacent deposits. Sedimentary units, also in unconformable contact, are well indurated and composed of Wailuku Basalt fragments

Qwlc Lava cone-Numerous, very thinly bedded lava flows thought to define near-vent accumulation. Mapped only along south coast

Qwp Phreatic explosion debris - Thin beds of lithic breccia containing blocks of Wailuku Basalt lava in a gray comminuted matrix [p. 172]. Deposits thin rapidly seaward, indicating explosions from vents in or near south end of summit caldera [p. 172]

Qwdc Dike complex-Closely spaced dikes. Individual dikes mostly less than 1 m wide, but abundance sufficiently great to exceed the area exposed by intervening wall rock

Qwcc Caldera complex-Firmly cemented vent breccia, lava flows, indurated talus, and pyroclastic deposits - an amalgam described as "the whole gamut of rocks" by Stearns and Macdonald (1942, their map-plate description). Characterizes a sequence of lithologically diverse volcanic products that individually are too restricted in their extent to be mapped separately [p. 166]. Interpreted as the accumulation of material in main summit caldera of West Maui volcano

Qwi Intrusive rocks_-Basaltic dikes and sparse plugs

\section{VOLCANIC AND INTRUSIVE ROCKS ON THE ISLAND OF HAWAI‘I}

\section{KĪLAUEA VOLCANO}

[Bracketed page numbers refer to Geologic Map of Island of Hawai'i (Wolfe and Morris, 1996a), which is the chief source for description of Hawai`i Island geologic map units]

Puna Basalt (Holocene and Pleistocene) - Vent deposits (unit Qpc), lava flows (unit Qp), littoral deposits (unit Qpld), and tephra deposits (unit Qpa) of tholeiitic basalt and rare transitional and alkalic basalt [p. 10]. Among lava flows, pāhoehoe slightly more abundant than 'a‘ā. Variably porphyritic, with phenocrysts of olivine, plagioclase, and rarely, pyroxene. Divided on the basis of lithology and age according to the following matrix (y, younger; o, older). West of Glenwood (fig. 29), a vast area 
blanketed by tephra of the Puna Basalt (unit Qpa2; Wolfe and Morris, 1996a) is mapped to show the extents of partially buried lava flows from Kīlauea and Mauna Loa, following the presentation of Trusdell and others (2006). Similarly, unit Qpa4y, which corresponds to the Keanakāko'i Ash Member of the Puna Basalt, is shown more restrictively across its extent in the summit area of Kîlauea Volcano. Age formally redefined here as Holocene and Pleistocene, in order to include lava flows of late Pleistocene age exposed at base sequence in upper slope of Hilina Pali (table 2)

\begin{tabular}{|c|c|c|c|c|c|}
\hline $\begin{array}{c}\text { Vent } \\
\text { deposits }\end{array}$ & \multicolumn{2}{|c|}{ Lava flows } & $\begin{array}{l}\text { Littoral } \\
\text { deposits }\end{array}$ & $\begin{array}{l}\text { Tephra } \\
\text { deposits }\end{array}$ & Age, years \\
\hline Qpc5 & Qp5 & & Qpld5 & Qpa5 & $0-200$ \\
\hline Qpc4y & \multirow{2}{*}{ Qp4 } & Qp4y & & Qpa4y & $200-400$ \\
\hline Qpc4o & & Qp4o & Qpld4o & Qpa4o & $400-750$ \\
\hline Qpc3 & Qp3 & & Qpld3 & & $750-1,500$ \\
\hline \multirow[t]{3}{*}{ Qpc2 } & Qp2 & & & Qpa2 & $1,500-3,000$ \\
\hline & Qp1y & & & & $3,000-5,000$ \\
\hline & Qp1o & & & & $5,000-16,000$ \\
\hline
\end{tabular}

Qhi Hilina Basalt (Pleistocene) —Lava flows and minor interbedded tephra deposits of tholeiitic basalt [p. 11]. Lithologically similar to overlying Puna Basalt, but the two units are separated by a widespread sequence of fallout tephra (unit Qt), the Pāhala Ash of previous workers

\section{MAUNA LOA VOLCANO}

$\mathrm{Ka}^{6} \overline{\mathbf{u}}$ Basalt (Holocene and Pleistocene) - Vent deposits (unit Qkc), lava flows (unit Qk), littoral deposits (unit Qkld), and tephra deposits (unit Qka) of tholeiitic basalt and rare transitional and alkalic basalt [p. 10]. Among lava flows, pāhoehoe slightly more abundant than ' $a$ 'ā. Variably porphyritic, with phenocrysts of olivine, plagioclase, and rarely, pyroxene. Divided on the basis of lithology and age according to the following matrix (y, younger; o, older)

\begin{tabular}{|c|c|c|c|c|c|c|}
\hline \multicolumn{2}{|c|}{$\begin{array}{c}\text { Vent } \\
\text { deposits }\end{array}$} & \multicolumn{2}{|c|}{ Lava flows } & \multirow{2}{*}{$\begin{array}{c}\begin{array}{c}\text { Littoral } \\
\text { deposits }\end{array} \\
\text { Qkld5 }\end{array}$} & $\begin{array}{l}\text { Tephra } \\
\text { deposits }\end{array}$ & \multirow{2}{*}{$\stackrel{\text { Age, years }}{\ulcorner 0-200}$} \\
\hline Qkc5 & & Qk5 & & & & \\
\hline Qkc4 & & Qk4 & & Qkld4 & & 200-750 \\
\hline Qkc3 & & Qk3 & & Qkld3 & Qka3 & $750-1,500$ \\
\hline Qkc2 & & Qk2 & & Qkld2 & & $1,500-3,000$ \\
\hline \multirow{2}{*}{ Qkc1 } & Qkc1y & \multirow{2}{*}{ Qk1 } & Qk1y & \multirow{2}{*}{ Qkld1 } & & $3,000-5,000$ \\
\hline & Qkc1o & & Qk10 & & & $5,000-11,000$ \\
\hline Qkc & & Qk & & & & $>11,000$ \\
\hline
\end{tabular}

Qkh Kahuku Basalt (Pleistocene)—Lava flows and minor interbedded tephra deposits of tholeiitic basalt [p. 12]. Lithologically similar to overlying $\mathrm{Ka}^{\prime} \overline{\mathrm{u}}$ Basalt, but the two units are separated by a widespread sequence of fallout tephra (unit Qt), the Pāhala Ash of previous workers

Qn Nīnole Basalt (Pleistocene) - Thin 'a'āa and pāhoehoe lava flows, minor interbedded tuff, and sparse dikes exposed as erosional remnants on scattered hills in the southern part of Mauna Loa's southwest flank. Age poorly determined but in the range 300-100 ka on basis of K-Ar geochronology. Thought to be eruptive products of early southwest rift zone of Mauna Loa that were isolated by massive landsliding of the volcano's west flank [p. 12]

\section{KĪLAUEA AND MAUNA LOA VOLCANOES}

Qcw Steep walls of calderas and pit craters (Holocene) - Lava flows and thin tephra beds exposed as a consequence of caldera- or crater-floor collapse. Deposits vary in age depending on depth of exposure; therefore several stratigraphic units may be included at different locations. Shown on Kīlauea and Mauna Loa. In walls of Kīlauea caldera, as much as $130 \mathrm{~m}$ (440 ft) of exposed strata range in age 
from 600 to 3,000 yr (corresponding to lava units Qp4, Qp3, and Qp2). Lava older than 3,000 yr (thus in Qp1y) conceivably is exposed in Pauahi and Makaopuhi Craters on the east rift zone, on basis of tephrastratigraphy (D.A. Swanson, written commun., 2009). On Mauna Loa, highest walls are at the summit caldera, Moku'āweoweo, where $180 \mathrm{~m}(600 \mathrm{ft})$ of exposed strata range in age from 3,000 to 200 yr B.P. (corresponding to lava units Qk4, Qk3, and Qk2; F.A. Trusdell, written commun., 2009). Three pit crater walls on lower southwest rift zone that were shown as unit Qcw by Wolfe and Morris (1996a) are depicted here more precisely as Kahuku Basalt (unit Qkh)

\section{HUALĀLAI VOLCANO}

Hualālai Volcanics (Holocene and Pleistocene) - Vent deposits and lava flows of transitional and alkali basalt and trachyte [p. 12]. The basaltic units are divided on basis of lithology and age according to the following matrix; whereas the trachyte belongs to a separately named member

\begin{tabular}{|c|c|c|c|}
\hline $\begin{array}{c}\text { Vent } \\
\text { deposits }\end{array}$ & $\begin{array}{l}\text { Lava } \\
\text { flows } \\
\end{array}$ & $\begin{array}{c}\text { Tephra } \\
\text { deposits }\end{array}$ & Age, years \\
\hline Qhc5 & Qh5 & & $0-200$ \\
\hline Qhc4 & Qh4 & Qha4 & $200-750$ \\
\hline Qhc3 & Qh3 & & $750-1,500$ \\
\hline Qhc2 & Qh2 & & $1,500-3,000$ \\
\hline Qhc1y & Qh1y & & $3,000-5,000$ \\
\hline Qhc10 & Qh10 & & $5,000-11,000$ \\
\hline Qhc & Qh & & $>11,000$ \\
\hline
\end{tabular}

Wa'awa'a Trachyte Member (Pleistocene) — Lava flow and vent deposits. Slightly porphyritic, containing fewer than 1 percent phenocrysts of biotite, plagioclase, and pyroxene. Widespread in subsurface, on basis of water-well data, xenolith inclusions elsewhere in Hualālai lava flows, and trachytic blocks in ejecta (unit Qha4) adjacent to a cinder cone south of Hualālai's summit. Emplaced across a span of about 20 k.y., on basis of radiometric ages ranging from about 114 to $92 \mathrm{ka}$ (Clague 1987b; Cousens and others, 2003). Divided into: Lava flow-Light-gray trachyte, altered to light brown where sheared [p. 13]. Blocky scoriaceous top grades downward into dense lava. Crescentic flow ridges 3-18 $\mathrm{m}$ high increase in height toward terminus of flow (Stearns and Macdonald, 1946). Terraces on its slopes suggest it is composed of several flow units 80-150 m thick (Stearns and Macdonald, 1946; Shea and others, 2017). Total thickness exceeds $275 \mathrm{~m}$; base not exposed (Clague and Bohrson, 1991). Cuttings from water well indicate two flow lobes, each at least $70 \mathrm{~m}$ thick, separated by about $40 \mathrm{~m}$ of pumice (Clague and Bohrson, 1991). Radiometric ages from lava flow and cone and from similar trachyte from water wells and disgorged blocks indicate eruption occurred during span of time from 114 to $92 \mathrm{ka}$ (Cousens and others, 2003)

Qwc Scoria cone - Generally loose fragments of pumice, obsidian, and massive, flow-banded trachyte [p. 13]. Other vents buried but required to explain subsurface distribution

\section{MAUNA KEA VOLCANO}

Laupāhoehoe Volcanics (Holocene and Pleistocene) - Volcanic rocks, composed of hawaiite, mugearite, and benmoreite, and associated glacial deposits [p. 13]. Divided into two informally named volcanic members and an intervening formally named glacial member, thus:

Younger volcanic rocks member (Holocene and Pleistocene?) —-Lava flows, scoria cones, and tephrafall deposits of hawaiite and mugearite. Postdates the Mākanaka Glacial Member (units Qlmt, Qlmo). Where glacial deposits are lacking, may be distinguished from older volcanic rocks on basis of youthful physiographic aspect and absence of mantling surficial deposits. Divided into:

Qlcy Qly Qlay

Scoria cones-Vesicular lapilli with lesser amounts of ash and bombs; some spatter

Lava flows - Predominantly ' $a$ 'ā and blocky 'a'ā. Pāhoehoe found locally

Tephra-fall deposits-Lapilli and ash. Distributed downwind from pyroclastic eruption columns. Shown only on east half of Mauna Kea, where deposits are found on leeward side of scoria cones (in unit Qlcy). On west half, stratigraphically equivalent tephra are dispersed more widely and mapped as part of tephra-fall deposits of the older volcanic rocks member (unit Qla) 
Older volcanic rocks member (Holocene and Pleistocene) — Lava flows, scoria cones, and tephra-fall deposits of hawaiite, mugearite, and benmoreite. Divided into: Tephra-fall deposits (Holocene and Pleistocene)—Lapilli and ash distributed downwind during eruptions of pyroclastic material at cinder cones. Chiefly Pleistocene in age but locally includes tephra stratigraphically equivalent to that in the younger volcanic rocks member (unit Qlay). On larger-scale geologic map, all tephra of Laupāhoehoe age are included in a single map unit (Wolfe and others, 1997, their air-fall deposits of the Laupāhoehoe Volcanics)

Qlc Qlbc

QI Qlb

QImt

QImo

Qhmc

Qhm

Qhmw

Qhmp

Scoria cones (Pleistocene) - Unit is mapped separately as:

Two cones with benmoreite composition-Two benmoreite cones identified on basis of chemical composition

Lava flows (Pleistocene) - Unit is mapped separately as:

Benmoreite lava flows-Benmoreite lava flows on northwest flank, identified on basis of chemical composition

Mākanaka Glacial Member (Pleistocene)—Glacial deposits. Divided into:

Till—Poorly sorted, poorly consolidated deposits containing subangular to subrounded pebbles, cobbles, and boulders in finer-grained matrix

Outwash—Subrounded to well-rounded silt, sand, and cobbly to bouldery gravel. Moderately well sorted

Hāmākua Volcanics (Pleistocene) — Basaltic volcanic rocks and associated glacial deposits. Volcanic member is divided to show lava flows separately from vent deposits. Consists of:

Basalt —Lava flows and cinder cones of alkalic and transitional basalt, minor hawaiite, tholeiitic basalt, and strongly undersaturated basalt. Variably porphyritic, with phenocrysts of olivine, plagioclase, and clinopyroxene. Divided into:

Vent deposits-Scoria cones

Lava flows - ' $A$ ' $\bar{a}$ and pāhoehoe from vents distributed widely across the volcano

Waihū Glacial Member-Chiefly till; thin beds of gravel occur as lenses or tongues locally. Exposed only on southwest flank

Pōhakuloa Glacial Member-Chiefly till; thin beds of glaciofluvial gravel occur locally. Separated from Waihū Glacial Member by lava flows of the Hāmākua Volcanics

\section{KOHALA VOLCANO}

Hāwī Volcanics (Pleistocene) - Vent deposits (unit Qhwc), lava domes (unit Qhwd), lava flows (unit Qhw), and tephra-fall deposits (unit Qhwa) of hawaiite, mugearite, benmoreite (unit Qhwb), and trachyte (unit Qhwt) [p. 14]. Aphyric to sparsely porphyritic. Divided on basis of lithology and composition according to the following matrix. (No implication for age relations among parts of the unit)

\begin{tabular}{|c|c|c|c|c|}
\hline $\begin{array}{c}\text { Vent } \\
\text { deposits }\end{array}$ & $\begin{array}{l}\text { Lava } \\
\text { domes }\end{array}$ & $\begin{array}{l}\text { Lava } \\
\text { flows }\end{array}$ & $\begin{array}{l}\text { Tephra } \\
\text { deposits }\end{array}$ & Composition \\
\hline Qhwc & Qhwd & Qhw & Qhwa & $\begin{array}{c}\text { Hawaiite and } \\
\text { muoearite }\end{array}$ \\
\hline \multirow[t]{2}{*}{ Qhwbc } & Qhwbd & Qhwb & & Benmoreite \\
\hline & Qhwtd & Qhwt & & Trachyte \\
\hline
\end{tabular}

Pololū Volcanics (Pleistocene) - Vent deposits (unit Qplc), a lava dome (unit Qpld), and lava flows (unit $\mathrm{Qpl})$. Most lava is basaltic, ranging from tholeiite to alkalic basalt and rarely hawaiite. Sparse mugearite lava flows (unit Qplm) and the single identified mugearite cone (unit Qplmc) are mapped separately, according to the following matrix. The lava dome is basaltic

\begin{tabular}{|l|l|l|l|l|}
\multicolumn{1}{c}{$\begin{array}{c}\text { Vent } \\
\text { deposits }\end{array}$} & \multicolumn{2}{c}{$\begin{array}{c}\text { Lava } \\
\text { dome }\end{array}$} & \multicolumn{2}{c}{$\begin{array}{c}\text { Lava } \\
\text { flows }\end{array}$} \\
\hline Qplc & Qplmc & Qpld & Qpl & Qplm \\
\hline
\end{tabular}




\section{Acknowledgments}

A project of this scope grows serendipitously, and a listing of compatriots becomes overwhelming. Acknowledged here specifically are a few for their sharing of data, concepts, and fieldwork: Glenn Bauer, David Clague, Brent Dalrymple, Dick Fiske, Amy Gaffney, Mike Garcia, Steve Gingerich, Tony Hartshorn, Rick Hazlett, Christina Heliker, Paul Higashino, Scot Izuka, Jenda Johnson, Jim Kauahikaua, Jack McGeehin, Takashi Murai, Ron Nagata, Yoshitomo Nishimitsu, David Okita, Tim Orr, Nora Shew, Forrest Starr, Don Swanson, Takahiro Tagami, Frank Trusdell, Ric Wilson, Ed Wolfe, and Tom Wright. The map and text were reviewed by Don Swanson, Ed Wolfe, Carolyn Donlin, Sarah Nagorsen, Claire Landowski, and Phil Frederick. With admiration we make special mention of librarian Jane Takahashi, whose resources at the Hawaiian Volcano Observatory sweetened what otherwise would have been nightmarish research.

This map began its progression to publication in 2008, received USGS Bureau approval in 2010, then lagged while in press. A hallmark of the Earth sciences is the rapid growth and development of ideas. Faced with that, we made sparse changes in 2017 and again in 2019 to revise the most glaring of differences between the original manuscript and an evolving understanding of Hawaiian Islands geology.

Mapping update for the Island of Hawai'i lava emplaced between 2004 and 2018 owes largely to field work by Hawaiian Volcano Observatory geologists Tim Orr, Matt Patrick, Carolyn Parcheta, and Liliana DeSmithers. The authors acknowledge the substantial GIS skills of Joel Robinson, who wrangled map data at several different scales and helped to gracefully incorporate the 2018 flows into the geologic map of the Island of Hawai' $i$; and Katie Sullivan, who constructed and finessed the base maps for all eight islands.

\section{References Cited}

Baksi, A.K., Hsu, V., McWilliams, M.O., and Farrar, E., 1992, ${ }^{40} \mathrm{Ar} /{ }^{39} \mathrm{Ar}$ dating of the Brunhes-Matuyama geomagnetic field reversal: Science, v. 256, p. 356-357.

Bauer, G.R., Fodor, R.V., Husler, J.W., and Keil, K., 1973, Contributions to the mineral chemistry of Hawaiian Rocks III., Composition and mineralogy of a new rhyodacite occurrence on Oahu, Hawaii: Contributions to Mineralogy and Petrology, v. 40, p. 183-194.

Beeson, M.H., 1976, Petrology, mineralogy, and geochemistry of the East Molokai Volcanic Series, Hawaii: U.S. Geological Survey Professional Paper 961, 53 p.

Bergmanis, E.C., 1998, Rejuvenated volcanism along the southwest rift zone, East Maui, Hawaii-eruptive history of the Hana Volcanics: Mānoa, Univ. of Hawaii, M.S. thesis, 70 p.

Bergmanis, E.C., Sinton, J.M., and Trusdell, F.A., 2000, Rejuvenated volcanism along the southwest rift zone, East Maui, Hawai'i: Bulletin of Volcanology, v. 62, p. 239-255.

Blay, C.T., and Longman, M.W., 2001, Stratigraphy and sedimentology of Pleistocene and Holocene carbonate eolianites, Kaua'i, Hawai'i, U.S.A., in Abegg, F.E., Harris, P.M., and Loope, D.B., eds., Modern and ancient carbonate eolianites-Sedimentology, sequence stratigraphy, and diagenesis: Society of Exploration Petrologists and Mineralogists (SEPM) Special Publication 71, p. 93-115.

Bogue, S.W., and Coe, R.S., 1984, Transitional paleointensities from Kauai, Hawaii, and geomagnetic reversal models: Journal of Geophysical Research, v. 89, no. B12, p. 10341-10354.

Bonhommet, N., Beeson, M.H., and Dalrymple, G.B., 1977, A contribution to the geochronology and petrology of the island of Lanai, Hawaii: Geological Society of America Bulletin, v. 88, no. 9, p. 1282-1286.

Brill, R.C., 1975, The geology of the lower southwest rift of Haleakala, Hawaii: Mānoa, Univ. of Hawai'i, M.S. thesis, 65 p.

Buchanan-Banks, J.M., 1993, Geologic map of the Hilo 7 1 1/2' quadrangle, Island of Hawaii: U.S. Geological Survey Miscellaneous Investigations Series Map I-2274, scale 1:24,000.

Cannon, E.C., and Bürgman, R., 2001, Prehistoric fault offsets of the Hilina fault system, south flank of Kilauea Volcano, Hawaii: Journal of Geophysical Research, v. 106, no. B3, p. 4207-4219.

Chen, C.-Y., and Frey, F.A., 1985, Trace element and isotopic geochemistry of lavas from Haleakala volcano, East Maui, Hawaii-implications for the origin of Hawaiian basalts: Journal of Geophysical Research, v. 90, no. B10, p. 8743-8768.

Chen, C.-Y., Frey, F.A., and Garcia, M.O., 1990, Evolution of alkalic lavas at Haleakala Volcano, east Maui, Hawaii: Contributions to Mineralogy and Petrology, v. 105, p. 197-218.

Chen, C.-Y., Frey, F.A., Garcia, M.O., Dalrymple, G.B., and Hart, S.R., 1991, The tholeiite to alkalic basalt transition at Haleakala Volcano, Maui, Hawaii: Contributions to Mineralogy and Petrology, v. 106, p. 183-200.

Clague, D.A., 1982, Petrology of tholeiitic basalt dredged from Hualalai Volcano, Hawaii [abs.]: Eos (Transactions of American Geophysical Union), v. 63, no. 45, p. 1138.

Clague, D.A., 1987a, Petrology of West Molokai volcano [abs.]: Geological Society of America Abstracts with Programs, v. 19 , no. 6 , p. 366 .

Clague, D.A., 1987b, Hawaiian xenolith populations, magma supply rates, and development of magma chambers: Bulletin of Volcanology, v. 49, no. 4, p. 577-587.

Clague, D.A., 1990, Kauai, Hawaii, in Wood, C.A., and Kienle, J., eds., Volcanoes of North America: Cambridge, Cambridge University Press, p. 321-323.

Clague, D.A., 1996, The growth and subsidence of the Hawaiian-Emperor volcanic chain, in Keast, A., and Miller, S.E., eds., The origin and evolution of Pacific Island biotas, New Guinea to Eastern Polynesia: patterns and processes: Amsterdam, SPB Academic Publishing, p. 35-50.

Clague, D.A., and Beeson, M.H., 1980, Trace element geochemistry of the East Molokai Volcanic Series, Hawaii: American Journal of Science, v. 280-A (pt. 2), p. 820-844.

Clague, D.A., and Bohrson, W.A., 1991, Origin of xenoliths in the trachyte at Puu Waawaa, Hualalai volcano, Hawaii: Contributions to Mineralogy and Petrology, v. 108, p. 439-452.

Clague, D.A., and Dalrymple, G.B., 1987, The HawaiianEmperor volcanic chain, Part I, geologic evolution: U.S. Geological Survey Professional Paper 1350, v. 1, p. 5-54. 
Clague, D.A., and Dalrymple, G.B., 1988, Age and petrology of alkalic postshield and rejuvenated-stage lava from Kauai, Hawaii: Contributions to Mineralogy and Petrology, v. 99, p. 202-218.

Clague, D.A., Dao-gong, C., Murnane, R., Beeson, M.H., Lanphere, M.A., Dalrymple, G.B., Friesen, Walter, and Holcomb, R.T., 1982, Age and petrology of the Kalaupapa Basalt, Molokai, Hawaii: Pacific Science, v. 36, no. 4, p. 411-420.

Clague, D.A., Frey, F.A., Garcia, M.O., Huang, S., McWilliams, M., and Beeson, M.H., 2016, Compositional heterogeneity of the Sugarloaf melilite nephelinite flow, Honolulu Volcanics, Hawai'i: Geochimica Cosmochimica Acta, v. 185, p. 251-277.

Clague, D.A., and Frey, F.A., 1982, Petrology and trace element geochemistry of the Honolulu Volcanics, Oahu-Implications for the oceanic mantle below Hawaii: Journal of Petrology, v. 23, no. 3, p. 447-504.

Clague, D.A., Hagstrum, J.T., Champion, D.E., and Beeson, M.H., 1999, Kīlauea summit overflows - their ages and distribution in the Puna District, Hawai'i: Bulletin of Volcanology, v. 61, no. 6, p. 363-381.

Clague, D.A., and Moore, J.G., 2002, The proximal part of the giant submarine Wailau landslide, Molokai, Hawaii: Journal of Volcanology and Geothermal Research, v. 113, nos. 1-2, p. 259-287.

Clague, D.A., and Sherrod, D.R., 2014, Growth and degradation of Hawaiian volcanoes, chap. 3 of Poland, M.P., Takahashi, T.J., and Landowski, C.M., eds., Characteristics of Hawaiian volcanoes: U.S. Geological Survey Professional Paper 1801, p. 97-146, https://pubs.usgs.gov/pp/1801/.

Coe, R.S., Singer, B.S., Pringle, M.S., and Zhao, X., 2004, Matuyama-Brunhes reversal and Kamikatsura event on Maui-paleomagnetic directions, ${ }^{40} \mathrm{Ar} /{ }^{39} \mathrm{Ar}$ ages and implications: Earth and Planetary Science Letters, v. 222, p. 667-684.

Coombs, C.R., Hawke, B.R., and Wilson, L., 1990, Terrestrial analogs to lunar sinuous rilles-Kauhako crater and channel, Kalaupapa, Molokai, and other Hawaiian lava conduit systems: Proceedings of the 20th Lunar and Planetary Science Conference, v. 20, p. 195-206.

Coombs, M.L., Clague, D.A., Moore, G.F., and Cousens, B.L., 2004, Growth and collapse of Waianae Volcano, Hawaii, as revealed by exploration of its submarine flanks: Geochemistry, Geophysics, Geosystems $\left(\mathrm{G}^{3}\right)$, v. 5, no. 5, doi:10.1029/2004GC000717, 30 p.

Cousens, B.L., Clague, D.A., and Sharp, W.D., 2003, Chronology, chemistry, and origin of trachytes from Hualalai Volcano, Hawaii: Geochemistry, Geophysics, Geosystems $\left(\mathrm{G}^{3}\right)$, v. 4, no. 9, doi:10.1029/2003GC000560, 27 p.

Cross, W., 1915, Lavas of Hawaii and their relations: U.S. Geological Survey Professional Paper 88, 97 p.

Dalrymple, G.B., 1971, Potassium-argon ages from the Pololu Volcanic series, Kohala volcano, Hawaii: Geological Society of America Bulletin, v. 82, no. 7, p. 1997-1999.

Dalrymple, G.B., 1979, Critical tables for conversion of K-Ar ages from old to new constants: Geology, v. 7, no. 11, p. 558-560.

Dana, J.D., 1890, Characteristics of volcanoes, with contributions of facts and principles from the Hawaiian Islands: New York, Dodd, Mead, 399 p.
Diller, D.E., 1981, Structural evolution of West Maui volcano, Hawaii [abs.]: Eos (American Geophysical Union Transactions), v. 62, no. 45, p. 1068.

Diller, D.E., 1982, Contributions to the geology of West Maui volcano, Hawaii: Mānoa, Univ. of Hawai' ${ }^{\prime}$, M.S. thesis, 237 p.

Doell, R.R., 1972, Paleomagnetism of volcanic rocks from Niihau, Nihoa, and Necker Islands, Hawaii: Journal of Geophysical Research, v. 77, no. 20, p. 3725-3730.

Doell, R.R., and Cox, A., 1965, Paleomagnetism of Hawaiian lava flows: Journal of Geophysical Research, v. 70, no. 14, p. 3377-3405.

Doell, R.R., and Dalrymple, G.B., 1973, Potassium-argon ages and paleomagnetism of the Waianae and Koolau Volcanic Series, Oahu, Hawaii: Geological Society of America Bulletin, v. 84, no. 4, p. 1217-1241.

Eakins, B.W., Robinson, J.E., Kanamatsu, T., Naka, J., Smith, J.R., Takahashi, E., and Clague, D.A., 2003, Hawaii's volcanoes revealed: U.S. Geological Survey Geologic Investigations Series Map I-2809, scale about 1:850,000.

Easton, R.M., 1987, Stratigraphy of Kilauea Volcano: U.S. Geological Survey Professional Paper 1350, v. 1, p. 243-260.

Easton, W.H., and Olson, E.A., 1976, Radiocarbon profile of Hanauma Reef, Oahu, Hawaii: Geological Society of America Bulletin, v. 87, no. 5, p. 711-719.

Evernden, J.F., Savage, D.E., Curtis, G.H., and James, G.T., 1964, Potassium-argon dates and the Cenozoic mammalian chronology of North America: American Journal of Science, v. 262, p. 145-198.

Feigenson, M.D., 1984, Geochemistry of Kauai volcanics and a mixing model for the origin of Hawaiian alkali basalts: Contributions to Mineralogy and Petrology, v. 87, no. 2, p. 109-119.

Felton, E.A., Crook, K.A.W., and Keating, B.H., 2000, The Hulopoe Gravel, Lanai, Hawaii-new sedimentological data and their bearing on the "giant wave" (mega-tsunami) emplacement hypothesis: Pure and Applied Geophysics, v. 157 , nos. 6-8, p. 1257-1284.

Ferrall, C.C., 1981, Evidence for Honolulu Volcanic Series eruptions less than 12,000 years before present [abs.]: Eos (Transactions of American Geophysical Union), v. 62, no. 17, p. 431.

Fiske, R.S., and Jackson, E.D., 1972, Orientation and growth of Hawaiian volcanic rifts - the effect of regional structure and gravitational stresses: Proceedings of the Royal Society of London, series A, v. 329, p. 299-326.

Fiske, R.S., Rose, T.R., Swanson, D.A., Champion, D.E., and McGeehin, J.P., 2009, Kulanaokuaiki Tephra (ca. A.D. 400-1000) — newly recognized evidence for highly explosive eruptions at Kīlauea Volcano, Hawai'i: Geological Society of America Bulletin, v. 121, nos. 5-6, p. 712-728, https://doi.org/10.1130/B26327.1.

Fletcher, C.H., Murray-Wallace, C.V., Glenn, C.R., Sherman, C.E., and Popp, B., 1999, Late Quaternary eolianite geochemistry, petrology, and aminostratigraphy at Kaiehu Point (Moomomi), Molokai, Hawaii, in Fletcher, C.N. III, ed., Molokai field trip guide for participants of the nonsteady state of the inner shelf and shoreline-coastal change on the time scale of decades to millennia in the late Quaternary: Honolulu, University of Hawaii, p. 15-41. 
Fodor, R.V., Frey, F.A., Bauer, G.R., and Clague, D.A., 1992, Ages, rare-earth element enrichment, and petrogenesis of tholeiitic and alkalic basalts from Kahoolawe Island, Hawaii: Contributions to Mineralogy and Petrology, v. 110, p. $442-462$.

Fodor, R.V., Rudek, E.A., and Bauer, G.R., 1993, Hawaiian magma-reservoir processes as inferred from the petrology of gabbro xenoliths in basalt, Kahoolawe Island: Bulletin of Volcanology, v. 55, p. 204-218.

Frey, F.A., Garcia, M.O., and Roden, M.F., 1994, Geochemical characteristics of Koolau Volcano - implications of intershield differences among Hawaiian volcanoes: Geochimica et Cosmochimica Acta, v. 58, no. 5, p. 1441-1462.

Funkhouser, J.G., Barnes, I.L., and Naughton, J.J., 1966, Problems in the dating of volcanic rocks by the potassiumargon method: Bulletin of Volcanology, v. 29, p. 709-717.

Funkhouser, J.G., Barnes, I.L., and Naughton, J.J., 1968, The determination of a series of ages of Hawaiian volcanoes by the potassium-argon method: Pacific Science, v. 22, p. 369-372.

Gaffney, A.M., Nelson, B.K., and Blichert-Toft, J., 2004, Geochemical constraints on the role of oceanic lithosphere in intra-volcano heterogeneity at West Maui, Hawaii: Journal of Petrology, v. 45, no. 8, p. 1663-1687.

Garcia, M.O., 1993, Pliocene-Pleistocene volcanic sands from Site 842: products of giant landslides, in Wilkens, R.H., Firth, J. , and Bender, J., eds., Proceedings of the Ocean Drilling Program, scientific results, Hawaiian Arch: College Station, Texas, Ocean Drilling Program, v. 136, p. 53-63.

Garcia, M.O., Swinnard, L., Weis, D., Greene, A.R., Tagami, T., Sano, H., and Gandy, C.E., 2010, Petrology, geochemistry, and geochronology of Kaua'i lavas over 4.5 Myr-implications for the origin of rejuvenated volcanism and the evolution of the Hawaiian plume: Journal of Petrology, v. 51, no. 7, p. 1507-1540, https://doi.org/10.1093/petrology/egq027.

Gibbard, P., and Van Kolfschoten, T., 2004, The Pleistocene and Holocene epochs, chap. 22 of Gradstein, F.M., Ogg, J.G., and Smith, A.G., eds., A geologic time scale 2004 (reprinted with corrections 2006): Cambridge, Cambridge University Press, p. 441-452.

Gibbard, P.L., Head, M.J., Walker, M.J.C., and the Subcommission on Quaternary Stratigraphy, 2010, Formal ratification of the Quaternary System/Period and the Pleistocene Series/Epoch with a base at 2.58 Ma: Journal of Quaternary Science, v. 25, no. 2, p. 96-102, https://doi.org/10.1002/jqs.1338.

Gingerich, S.B., and Izuka, S.K., 1997a, Construction, geologic log, and aquifer tests of the Northwest Kilohana monitor well (State Well 2-0126-01), Lihue, Kauai, Hawaii: U.S. Geological Survey Open-File Report 97-40, 20 p.

Gingerich, S.B., and Izuka, S.K., 1997b, Construction, geologic log, and aquifer tests of the Puakukui Springs Monitor Well (State well 2-5626-01), Lihue, Kauai, Hawaii: U.S. Geological Survey Open-File Report 97-38, 18 p.

Gradstein, F.M., Ogg, J.G., and Smith, A.G., 2004, Construction and summary of the geologic time scale, chap. 23 of Gradstein, F.M., Ogg, J.G., and Smith, A.G., eds., A geologic time scale 2004 (reprinted with corrections 2006): Cambridge, Cambridge University Press, p. 455-464.
Gramlich, J.W., Lewis, V.A., and Naughton, J.J., 1971, Potassiumargon dating of Holocene basalts of the Honolulu Volcanic Series: Geological Society of America Bulletin, v. 82, no. 5, p. 1399-1404.

Grigg, R.W., and Jones, A.T., 1997, Uplift caused by lithospheric flexure in the Hawaiian Archipelago as revealed by elevated coral deposits: Marine Geology, v. 141, p. 11-25.

Guillou, H., Turpin, L., Garnier, F., Charbit, S., and Thomas, D.M., 1997, Unspiked K-Ar dating of Pleistocene tholeiitic basalts from the deep core $\mathrm{SOH}-4$, Kilauea, Hawaii: Chemical Geology, v. 140, p. 81-88.

Guillou, H., Sinton, J., Laj, C., Kissel, C., and Szeremeta, N., 2000, New K-Ar ages of shield lavas from Waianae Volcano, Oahu, Hawaiian Archipelago: Journal of Volcanology and Geothermal Research, v. 96, p. 229-242.

Hammer, J.E., Coombs, M.L., Shamberger, P.J., and Kimura, J.-I., 2006, Submarine sliver in North Kona-A window into the early magmatic and growth history of Hualalai Volcano, Hawaii: Journal of Volcanology and Geothermal Research, v. 151, p. 157-188.

Haskins, E.H., and Garcia, M.O., 2004, Scientific drilling reveals geochemical heterogeneity within the Ko'olau shield, Hawai'i: Contributions to Mineralogy and Petrology, v. 147, no. 2, p. 162-188.

Hazlett, R.W., and Hyndman, D.W., 1996, Roadside geology of Hawai‘i: Missoula, Mont., Mountain Press Publishing Co., $304 \mathrm{p}$.

Hearty, P.J., 2002, The Ka'ena highstand of O'ahu, Hawai'i: further evidence of Antarctic ice collapse during the middle Pleistocene: Pacific Science, v. 56, no. 1, p. 65-81.

Hearty, P.J., Karner, D.B., Renne, P.R., Olson, S.L., and Fletcher, S., 2005, ${ }^{40} \mathrm{Ar} /{ }^{39} \mathrm{Ar}$ age of a young rejuvenation basalt flow: implications for the duration of volcanism and the timing of carbonate platform development during the Quaternary on Kaua'i, Hawaiian Islands: New Zealand Journal of Geology and Geophysics, v. 48, p. 199-211.

Hearty, P.J., Kaufman, D.S., Olson, S.L., and James, H.F., 2000, Stratigraphy and whole-rock amino acid geochronology of key Holocene and last interglacial carbonate deposits in the Hawaiian Islands: Pacific Science, v. 54, no. 4, p. 423-442.

Heliker, C.C., and Mattox, T.N., 2003, The first two decades of the $\mathrm{Pu}^{\prime} \mathrm{u}$ ' $\overline{\mathrm{O}}^{`} \overline{\mathrm{o}}-\mathrm{Ku}$ paianaha eruption: chronology and selected bibliography: U.S. Geological Survey Professional Paper 1676, p. 1-27.

Herrero-Bervera, E., Margas-Viñuela, J., and Valet, J.-P., 2000, Paleomagnetic study of the ages of lavas on the island of Lana'i, Hawai'i: Journal of Volcanology and Geothermal Research, v. 104, p. 21-31.

Herrero-Bervera, E., and Valet, J.-P., 2003, Paleomagnetism of a long sequence of lavas recorded on the Island of Lana'i, Hawai'i, USA [abs.]: Eos (Transactions of the American Geophysical Union), v. 84, no. 46, p. F529.

Holcomb, R.T., 1985, The caldera of East Molokai volcano, Hawaiian Islands: National Geographic Society Research Reports 1980-1983, v. 21, p. 81-87.

Holcomb, R.T., Nelson, B.K., Reiners, P.W., and Sawyer, N.-L., 2000, Overlapping volcanoes: the origin of Hilo Ridge, Hawaii: Geology, v. 28, no. 6, p. 547-550. 
Holcomb, R.T., Reiners, P.W., Nelson, B.K., and Sawyer, N.-L., 1997, Evidence for two shield volcanoes exposed on the island of Kauai, Hawaii: Geology, v. 25, no. 9, p. 811-814.

Horton, K.A., 1977, Geology of the upper southwest rift zone of Haleakala volcano, Maui, Hawaii: Mānoa, Univ. of Hawai`i, M.S. thesis, 115 p.

Ives, P.C., Levin, Betsy, Oman, C.L., and Rubin, M., 1967, U.S. Geological Survey radiocarbon dates IX: Radiocarbon, v. 9, p. 505-529.

Izuka, S.K., and Gingerich, S.B., 1997a, Construction, geologic log, and aquifer tests of the Hanamaulu monitor well (State Well 2-5923-08), Lihue, Kauai, Hawaii: U.S. Geological Survey Open-File Report 97-36, 23 p.

Izuka, S.K., and Gingerich, S.B., 1997b, Construction, geologic $\log$, and aquifer tests of the Northeast Kilohana monitor well (State Well 2-0124-01), Lihue, Kauai, Hawaii: U.S. Geological Survey Open-File Report 97-37, 21 p.

Izuka, S.K., and Gingerich, S.B., 1997c, Construction, geologic log, and aquifer tests of the Pukaki Reservoir monitor well (State Well 2-0023-01), Lihue, Kauai, Hawaii: U.S. Geological Survey Open-File Report 97-41, 22 p.

Izuka, S.K., and Gingerich, S.B., 1997d, Construction and geologic log of the South Wailua monitor well (State Well 2-0121-01), Lihue, Kauai, Hawaii: U.S. Geological Survey Open-File Report 97-38, 14 p.

Jackson, E.D., and Wright, T.L., 1970, Xenoliths in the Honolulu Volcanic Series, Hawaii: Journal of Petrology, v. 11, no. 2, p. 405-430.

Juvik, S.P., Juvik, J.O., and Paradise, T.R., 1998, Atlas of Hawai'i, 3d ed.: Honolulu, University of Hawai'i Press, 333 p.

Kauahikaua, J., Cashman, K.V., Clague, D.A., Champion, D., and Hagstrum, J.T., 2002, Emplacement of the most recent lava flows on Hualālai volcano, Hawai' $i$ : Bulletin of Volcanology, v. 64, p. 229-253.

Kauahikaua, J., Hildenbrand, T., and Webring, W., 2000, Deep magmatic structures of Hawaiian volcanoes, imaged by three-dimensional gravity models: Geology, v. 28, no. 10, p. 883-886.

Kay, R.W., and Gast, P.W., 1973, The rare earth content and origin of alkali-rich basalts: Journal of Geology, v. 81, no. 6, p. 653-682.

Kirch, P.V., Hartshorn, A.S., Chadwick, O.A., Vitousek, P.M., Sherrod, D.R., Coil, J., Holm, L., and Sharp, W.D., 2004, Environment, agriculture, and settlement patterns in a marginal Polynesian landscape: Proceedings of National Academy of Sciences, v. 101, no. 26, p. 9936-9941.

Krivoy, H.L., Baker, M., Jr., and Moe, E.E., 1965, A reconnaissance gravity survey of the Island of Kauai, Hawaii: Pacific Science, v. 19, no. 3, p. 354-358.

Krivoy, H.L., and Lane, M.P., 1965, A preliminary gravity survey of the Island of Lanai, Hawaii: Pacific Science, v. 19, no. 3, p. 346-348.

Laj, C., Guillou, H., Szeremeta, N., and Coe, R., 1999, Geomagnetic paleosecular variation at Hawaii around $3 \mathrm{Ma}$ from a sequence of 107 lava flows at Kaena Point (Oahu): Earth and Planetary Science Letters, v. 170, p. 365-376.

Langenheim, V.A.M., and Clague, D.A., 1987, The HawaiianEmperor volcanic chain, Part II, Stratigraphic framework of volcanic rocks of the Hawaiian Islands: U.S. Geological Survey Professional Paper 1350, v. 1, p. 55-84.

Lanphere, M.A., and Dalrymple, G.B., 1980, Age and strontium isotopic composition of the Honolulu Volcanic Series, Oahu, Hawaii: American Journal of Science, v. 280-A, p. 736-751.

Lanphere, M.A., and Frey, F.A., 1987, Geochemical evolution of Kohala Volcano, Hawaii: Contributions to Mineralogy and Petrology, v. 95, p. 100-113.

Le Bas, M.J., Le Maitre, R.W., Streckeisen, A., and Zanettin, B.A., 1986, Chemical classification of volcanic rocks based on the total alkali-silica diagram: Journal of Petrology, v. 27, no. 3, p. 745-750.

Leeman, W.P., Gerlach, D.C., Garcia, M.O., and West, H.B., 1994, Geochemical variations in lavas from Kahoolawe volcano, Hawaii-evidence for open system evolution of plume-derived magmas: Contributions to Mineralogy and Petrology, v. 116, p. 62-77.

Leopold, M., Morelli, A., and Schorghofer, N., 2016, Subsurface architecture of two tropical alpine desert cinder cones that hold water: Journal of Geophysical Research, Earth Surface, v. 121, p. 1148-1160, https://doi.org/10.1002/2016JF003853.

Lipman, P.W., 1980, The southwest rift zone of Mauna Loa: implications for structural evolution of Hawaiian volcanoes: American Journal of Science, v. 280-A, p. 752-776.

Lipman, P.W., 1995, Declining growth of Mauna Loa during the last 100,000 years - rates of lava accumulation vs. gravitational subsidence, in Rhodes, J.M., and Lockwood, J.P., eds., Mauna Loa Revealed: American Geophysical Union Geophysical Monograph 92, p. 45-80.

Lipman, P.W., and Calvert, A.T., 2011, Early growth of Kohala volcano and formation of long Hawaiian rift zones: Geology, v. 39, no. 7, p. 659-662, https://doi.org/10.1130/G31929.1.

Lipman, P.W., Lockwood, J.P., Okamura, R.T., Swanson, D.A., and Yamashita, K.M., 1985, Ground deformation associated with the 1975 magnitude-7.2 earthquake and resulting changes in activity of Kilauea Volcano, Hawaii: U.S. Geological Survey Professional Paper 1276, 45 p.

Lipman, P.W., Normark, W.R., Moore, J.G., Wilson, J.B., and Gutmacher, C.E., 1988, The giant submarine Alika debris slide, Mauna Loa, Hawaii: Journal of Geophysical Research, v. 93, no. B5, p. 4279-4299.

Lipman, P.W., Rhodes, J.M., and Dalrymple, G.B., 1990, The Ninole Basalt-implications for the structural evolution of Mauna Loa volcano, Hawaii: Bulletin of Volcanology, v. 53, p. 1-19.

Lipman, P.W., Sisson, T.W., Ui, T., Naka, J., and Smith, J.R., 2002, Ancestral submarine growth of Kîlauea volcano and instability of its south flank, in Takahashi, E., Lipman, P.W., Garcia, M.O., Naka, J., and Aramaki, S., eds., Hawaiian volcanoesdeep underwater perspectives: American Geophysical Union Geophysical Monograph 128, p. 161-191.

Lipman, P.W., and Swenson, A., 1984, Generalized geologic map of the southwest rift zone of Mauna Loa volcano, Hawaii: U.S. Geological Survey Miscellaneous Investigations Series Map I-1323, scale 1:100,000.

Lum, D., and Stearns, H.T., 1970, Pleistocene stratigraphy and eustatic history based on cores at Waimanalo, Oahu, Hawaii: Geological Society of America Bulletin, v. 81, no. 1, p. 1-16. 
Maaløe, S., James, D., Smedley, P., Petersen, S., and Garmann, L.B., 1992, The Koloa volcanic suite of Kauai, Hawaii: Journal of Petrology, v. 33, pt. 4, p. 761-784.

Macdonald, G.A., 1940a, Petrography of the Waianae Range, Oahu: Hawaii Division of Hydrography, Bulletin 5, p. 63-91.

Macdonald, G.A., 1940b, Petrography of Kahoolawe: Hawaii Division of Hydrography Bulletin 6, p. 149-173.

Macdonald, G.A., 1947, Petrography of Niihau: Hawaii Division of Hydrography, Bulletin 12, pt. 2, p. 39-51.

Macdonald, G.A., 1968, Composition and origin of Hawaiian lavas: Geological Society of America Memoir 116, p. 477-522.

Macdonald, G.A., 1971, Geologic map of the Mauna Loa quadrangle, Hawaii: U.S. Geological Survey Geologic Quadrangle Map GQ-897, scale 1:24,000.

Macdonald, G.A., 1978, Geologic map of the crater section of Haleakalā National Park, Maui, Hawaii: U.S. Geological Survey Miscellaneous Investigations Map I-1088, scale $1: 24,000$.

Macdonald, G.A., Abbott, A.T., and Peterson, F.L., 1983, Volcanoes in the sea, 2d ed.: Honolulu, University of Hawaii Press, 517 p.

Macdonald, G.A., Davis, D.A., and Cox, D.C., 1960, Geology and ground-water resources of the Island of Kauai, Hawaii: Hawaii Division of Hydrography Bulletin 13, 212 p.

Macdonald, G.A., and Katsura, T., 1964, Chemical composition of Hawaiian lavas: Journal of Petrology, v. 5, no. 1, p. 82-133.

Macdonald, G.A., and Powers, H.A., 1946, Contribution to the petrography of Haleakala volcano, Hawaii: Geological Society of America Bulletin, v. 57, no. 1, p. 115-123.

Macdonald, G.A., and Powers, H.A., 1968, A further contribution to the petrology of Haleakala volcano, Hawaii: Geological Society of American Bulletin, v. 79, no. 7, p. 877-887.

Malinowski, M.J., 1977, Geology of the Kawaihae quadrangle, Kohala Mountain, Island of Hawaii: Mānoa, Univ. of Hawai'i, M.S. thesis, 155 p.

Mastin, L.G., Christiansen, R.L., Swanson, D.A., Stauffer, P.H., and Hendley, J.W., II, 1999, Explosive eruptions at Kīlauea Volcano, Hawai'i?: U.S. Geological Survey Fact Sheet 132-98, 2 p.

McDougall, I., 1963, Potassium-argon ages from western Oahu, Hawaii: Nature, v. 197, no. 4865, p. 344-345.

McDougall, I., 1964, Potassium-argon ages from lavas of the Hawaiian Islands: Geological Society of America Bulletin, v. 75, no. 2, p. 107-127.

McDougall, I., 1969, Potassium-argon ages on lavas of Kohala volcano, Hawaii: Geological Society of America Bulletin, v. 80 , no. 12 , p. 2597-2600.

McDougall, I., 1979, Age of shield-building volcanism of Kauai and linear migration of volcanism in the Hawaiian island chain: Earth and Planetary Science Letters, v. 46, p. 31-42.

McDougall, I., and Aziz-ur-Rahman, 1972, Age of the GaussMatuyama boundary and of the Kaena and Mammoth events: Earth and Planetary Science Letters, v. 14, p. 367-380.

McDougall, I., and Swanson, D.A., 1972, Potassium-argon ages of lavas from the Hawi and Pololu Volcanic Series, Kohala volcano, Hawaii: Geological Society of America Bulletin, v. 83, no. 12, p. 3731-3737.
McMurtry, G.M., Fryer, G.J., Tappin, D.R., Wilkinson, I.P., Williams, M., Fietzke, J., Garbe-Schoenberg, D., and Watts, P., 2004, Megatsunami deposits on Kohala volcano, Hawaii, from flank collapse of Mauna Loa: Geology, v. 32, no. 9, p. 741-744.

McMurtry, G.M., Herrero-Bervera, E., Cremer, M.D., Smith, J.R., Resig, J., Sherman, C., and Torresan, M.E., 1999, Stratigraphic constraints on the timing and emplacement of the Alika 2 giant Hawaiian submarine landslide: Journal of Volcanology and Geothermal Research, v. 94, p. 35-58.

McPhie, J., Walker, G.P.L., and Christiansen, R.L., 1990, Phreatomagmatic and phreatic fall and surge deposits from explosions at Kilauea volcano, Hawaii, 1790 A.D.Keanakakoi Ash Member: Bulletin of Volcanology, v. 52, p. 334-354.

Moore, A.L., 2000, Landward fining in onshore gravel as evidence for a late Pleistocene tsunami on Molokai, Hawaii: Geology, v. 28, no. 3, p. 247-250.

Moore, G.W., and Moore, J.G., 1988, Large-scale bedforms in boulder gravel produced by giant waves in Hawaii: Geological Society of America Special Paper 229, p. 101-110.

Moore, J.G., 1987, Subsidence of the Hawaiian Ridge: U.S. Geological Survey Professional Paper 1350, v. 1, p. 85-100.

Moore, J.G., Bryan, W.B., and Ludwig, K.R., 1994, Chaotic deposition by a giant wave, Molokai, Hawaii: Geological Society of America Bulletin, v. 106, no. 7, p. 962-967.

Moore, J.G., and Campbell, J.F., 1987, Age of tilted reefs, Hawaii: Journal of Geophysical Research, v. 92, no. B3, p. 2641-2646.

Moore, J.G., and Clague, D., 1987, Coastal lava flows from Mauna Loa and Hualalai volcanoes, Kona, Hawaii: Bulletin of Volcanology, v. 49, p. 752-764.

Moore, J.G., and Clague, D.A., 1992, Volcano growth and evolution of the island of Hawaii: Geological Society of America Bulletin, v. 104, no. 11, p. 1471-1484.

Moore, J.G., and Clague, D.A., 2002, Mapping the Nuuanu and Wailau landslides in Hawaii, in Takahashi, E., Lipman, P.W., Garcia, M.O., Naka, J., and Aramaki, S., eds., Hawaiian volcanoes - deep underwater perspectives: American Geophysical Union Geophysical Monograph 128, p. 223-244.

Moore, J.G., Clague, D.A., Holcomb, R.T., Lipman, P.W., Normark, W.R., and Torresan, M.E., 1989, Prodigious submarine landslides on the Hawaiian Ridge: Journal of Geophysical Research, v. 94, no. B12, p. 17465-17484.

Moore, J.G., Clague, D.A., and Normark, W.R., 1982, Diverse basalt types from Loihi seamount, Hawaii: Geology, v. 10, no. 2, p. 88-92.

Moore, J.G., and Moore, G.W., 1984, Deposit from a giant wave on the Island of Lanai, Hawaii: Science, v. 226, p. 1312-1315.

Moore, R.B., and Clague, D.A., 1991, Geologic map of Hualalai volcano, Hawaii: U.S. Geological Survey Miscellaneous Investigations Series Map I-2213, scale 1:50,000.

Moore, R.B., Clague, D.A., Rubin, M., and Bohrson, W.A., 1987, Hualalai Volcano - a preliminary summary of geologic, petrologic, and geophysical data: U.S. Geological Survey Professional Paper 1350, v. 1, p. 571-585.

Muir, I.D., and Tilley, C.E., 1963, Contributions to the petrology of Hawaiian basalts, II. The tholeiitic basalts of Mauna Loa 
and Kilauea: American Journal of Science, v. 261, no. 2, p. 111-128.

Mukhopadhyay, S., Lassiter, J.C., Farley, K.A., and Bogue, S.W., 2003, Geochemistry of Kauai shield-stage lavasImplications for the chemical evolution of the Hawaiian plume: Geochemistry, Geophysics, Geosystems $\left(\mathrm{G}^{3}\right)$, v. 4, no. 1, 32 p., https://doi.org/10.1029/2002GC000342.

Naka, J., Kanamatsu, T., Lipman, P.W., Sisson, T.W., Tsuboyama, N., Morgan, J.K., Smith, J.R., and Ui, T., 2002, Deep-sea volcaniclastic sedimentation around the southern flank of Hawaii, in Takahashi, E., Lipman, P.W., Garcia, M.O., Naka, J., and Aramaki, S., eds., Hawaiian volcanoes - Deep underwater perspectives: American Geophysical Union Geophysical Monograph 128, p. 29-50.

Naughton, J.J., Macdonald, G.A., and Greenberg, V.A., 1980, Some additional potassium-argon ages of Hawaiian rocks - the Maui volcanic complex of Molokai, Maui, Lanai and Kahoolawe: Journal of Volcanology and Geothermal Research, v. 7, p. 339-355.

Neal, C.A., Brantley, S.R., Antolik, L., Babb, J.L., Burgess, M., Calles, K., Cappos, M., Chang, J.C., Conway, S., Desmither, L., Dotray, P., Elias, T., Fukunaga, P., Fuke, S., Johanson, I.A., Kamibayashi, K., Kauahikaua, J., Lee, R.L., Pekalib, S., Miklius, A., Million, W., Moniz, C.J., Nadeau, P.A., Okubo, P., Parcheta, C., Patrick, M.R., Shiro, B., Swanson, D.A., Tollett, W., Trusdell, F., Younger, E.F., Zoeller, M.H., Montgomery-Brown, E.K., Anderson, K.R., Poland, M.P., Ball, J.L., Bard, J., Coombs, M., Dietterich, H.R., Kern, C., Thelen, W.A., Cervelli, P.F., Orr, T., Houghton, B.F., Gansecki, C., Hazlett, R., Lundgren, P., Diefenbach, A.K., Lerner, A.H., Waite, G., Kelly, P., Clor, L., Werner, C., Mulliken, K., and Fisher, G., 2019, The 2018 rift eruption and summit collapse of Kīlauea Volcano: Science, v. 363, no. 6425, p. 367-374, https://doi. org/10.1126/science.aav7046.

Ogg, J.G., and Smith, A.G., 2004, The geomagnetic polarity time scale, chap. 5 of Gradstein, F.M., Ogg, J.G., and Smith, A.G., eds., A geologic time scale 2004 (reprinted with corrections 2006): Cambridge, Cambridge University Press, p. 63-86.

Oostdam, B.L., 1965, Age of lava flows on Haleakala, Maui, Hawaii: Geological Society of America Bulletin, v. 76, no. 3, p. 393-394.

Ozawa, A., Tagami, T., and Garcia, M.O., 2005, Unspiked K-Ar dating of the Honolulu rejuvenated and Koolau shield volcanism on Oahu, Hawaii: Earth and Planetary Science Letters, v. 232, p. 1-11.

Palmiter, D.B., 1975, Geology of the Koloa Volcanic Series of the south coast of Kauai, Hawaii: Mānoa, University of Hawai'i, M.S. thesis, 87 p.

Peng, L., and King, J.W., 1992, A late Quaternary geomagnetic secular variation record from Lake Waiau, Hawaii, and the question of the Pacific nondipole low: Journal of Geophysical Research, v. 97, no. B4, p. 4407-4424.

Peterson, D.W., and Moore, R.B., 1987, Geologic history and evolution of geologic concepts, Island of Hawaii: U.S. Geological Survey Professional Paper 1350, v. 1, p. 149-189.
Porter, S.C., 1973, Stratigraphy and chronology of late Quaternary tephra along the south rift zone of Mauna Kea volcano, Hawaii: Geological Society of America Bulletin, v. 84 , no. 6, p. 1923-1939.

Porter, S.C., 1979, Quaternary stratigraphy and chronology of Mauna Kea, Hawaii - a 380,000-yr record of mid-Pacific volcanism and ice-cap glaciation: Geological Society of America Bulletin, v. 90, pt. 2, no. 7, p. 980-1093 (microfiche card 1, frames 3 through 95 and card 2, frames 3 through 21).

Porter, S.C., 1987, Pleistocene subglacial eruptions on Mauna Kea: U.S. Geological Survey Professional Paper 1350, v. 1, p. 587-598.

Porter, S.C., 1997, Late Pleistocene eolian sediments related to pyroclastic eruptions of Mauna Kea volcano, Hawaii: Quaternary Research, v. 47, p. 261-276.

Porter, S.C., Garcia, M.O., Lockwood, J.P., and Wise, W.S., 1987, Guidebook for Mauna Loa-Mauna Kea-Kohala field trip, Hawaii Symposium on How Volcanoes Work: International Association of Volcanology and Chemistry of the Earth's Interior, Hilo, Hawaii, Jan. 19-25, 1987, 40 p.

Potter, C.A., 1976, Basalts of West Molokai: Middlebury, Vt., Middlebury College, B.A. honors thesis, 89 p.

Presley, T.K., Sinton, J.M., and Pringle, M, 1997, Postshield volcanism and catastrophic wasting of the Waianae Volcano, Oahu, Hawaii: Bulletin of Volcanology, v. 58, p. 597-616.

Pukui, M.K., and Elbert, S.H., 1986, Hawaiian dictionary, revised and enlarged edition: Honolulu, University of Hawaii Press, 572 p.

Quane, S.L., Garcia, M.O., Guillou, H., and Hulsebosch, T.P., 2000, Magmatic history of the east rift zone of Kilauea Volcano, Hawaii based on drill core from SOH 1: Journal of Volcanology and Geothermal Research, v. 102, p. 319-338.

Reimer, P.J., Baillie, M.G.L., Bard, E., Bayliss, A., Beck, J.W., Bertrand, C.J.H., Blackwell, P.G., Buck, C.E., Burr, G.S., Cutler, K.B., Damon, P.E., Edwards, R.L., Fairbanks, R.G., Friedrich, M., Guilderson, T.P., Hogg, A.G., Hughen, K.A., Kromer, B., McCormac, F.G., Manning, S.W., Ramsey, C.B., Reimer, R.W., Remmele, S., Southon, J.R., Stuiver, M., Talamo, S., Taylor, F.W., van der Plicht, J., and Weyhenmeyer, C.E., 2004, IntCal04 terrestrial radiocarbon age calibration, 26 - 0 ka BP: Radiocarbon, v. 46, p. 1029-1058.

Reiners, P.W., and Nelson, B.K., 1998, Temporal-compositionalisotopic trends in rejuvenated-stage magmas of Kauai, Hawaii, and implications for mantle melting processes: Geochimica et Cosmochimica Acta, v. 62, no. 13, p. 2347-2368.

Reiners, P.W., Nelson, B.K., and Izuka, S.K., 1999, Structural and petrologic evolution of the Lihue basin and eastern Kauai, Hawaii: Geological Society of America Bulletin, v. 111, no. 5, p. 674-685.

Rhodes, J.M., 1996, Geochemical stratigraphy of lava flows sampled by the Hawaii Scientific Drilling Project: Journal of Geophysical Research, v. 101, no. B5, p. 11729-11746.

Riley, C.M., Diehl, J.F., Kirschvink, J.L., and Ripperdan, R.L., 1999, Paleomagnetic constraints on fault motion in the Hilina Fault System, south flank of Kilauea Volcano, Hawaii: Journal of Volcanology and Geothermal Research, v. 94, p. 233-249. 
Robinson, J.E., and Eakins, B.W., 2006, Calculated volumes of individual shield volcanoes at the young end of the Hawaiian Ridge: Journal of Volcanology and Geothermal Research, v. 151, p. 309-317.

Roden, M.F., Frey, F.A., and Clague, D.A., 1984, Geochemistry of tholeiitic and alkalic lavas from the Koolau Range, Oahu, Hawaii-implications for Hawaiian volcanism: Earth and Planetary Science Letters, v. 69, p. 141-158.

Rubin, K.H., Fletcher, C.H., III, and Sherman, C., 2000, Fossiliferous Lana'i deposits formed by multiple events rather than a single giant tsunami: Nature, v. 408, p. 675-681.

Rubin, M., Gargulinski, L.K., and McGeehin, J.P., 1987, Hawaiian radiocarbon dates: U.S. Geological Survey Professional Paper 1350, v. 1, p. 213-242.

Rubin, M., and Suess, H.E., 1956, U.S. Geological Survey radiocarbon dates III: Science, v. 123, no. 3194, p. 442-448.

Rudek, E.A., Fodor, R.V., and Bauer, G.R., 1992, Petrology of ultramafic and mafic xenoliths in picrite of Kahoolawe Island, Hawaii: Bulletin of Volcanology, v. 55, p. 74-84.

Sano, H., Sherrod, D.R., and Tagami, T., 2006, Youngest volcanism about 1 million years ago at Kahoolawe, Hawaii: Journal of Volcanology and Geothermal Research, v. 152, p. 91-96.

Satake, K., Smith, J.R., and Shinozaki, K., 2002, Three-dimensional reconstruction and tsunami model of the Nuuanu and Wailau giant landslides, Hawaii, in Takahashi, E., Lipman, P.W., Garcia, M.O., Naka, J., and Aramaki, S., eds., Hawaiian volcanoes_-deep underwater perspectives: American Geophysical Union Geophysical Monograph 128, p. 333-346.

Schorghofer, N., Leopold, M., and Yoshikawa, K., 2017, State of high-altitude permafrost on tropical Maunakea volcano, Hawaii: Permafrost and Periglacial Processes, v. 28, p. 685-697, https://doi.org/10.1002/ppp.1954.

Sharp, W.D., and Renne, P.R., 2005, The ${ }^{40} \mathrm{Ar} /{ }^{39} \mathrm{Ar}$ dating of core recovered by the Hawaii Scientific Drilling Project (phase 2), Hilo, Hawaii: Geochemistry, Geophysics, Geosystems $\left(\mathrm{G}^{3}\right)$, v. 6, no. 4, Q04G17, doi:10.1029/2004GC000846, 18 p.

Sharp, W.D., Turrin, B.D., Renne, P.R., and Lanphere, M.A., 1996, The ${ }^{40} \mathrm{Ar} /{ }^{39} \mathrm{Ar}$ and $\mathrm{K} / \mathrm{Ar}$ dating of lavas from the Hilo 1-km core hole, Hawaii Scientific Drilling Project: Journal of Geophysical Research, v. 101, no. B5, p. 11607-11616.

Shea, T., Leonhardi, T., Geichetti, T., Lindoo, A., Larsen, J., Sinton, J., and Parsons, E., 2017, Dynamics of an unusual cone-building trachyte eruption at Pu'u Wa'awa'a, Hualalai volcano, Hawai'i: Bulletin of Volcanology, v. 79, no. 4, art. 26, 24 p., https://doi.org/10.1007/s00445-017-1106-z.

Sherrod, D.R., Hagstrum, J.T., McGeehin, J.P., Champion, D.E., and Trusdell, F.A., 2006, Distribution, ${ }^{14} \mathrm{C}$ chronology, and paleomagnetism of latest Pleistocene and Holocene lava flows at Haleakalā volcano, Island of Maui, Hawai' $\mathrm{i}$ - A revision of lava-flow hazard zones: Journal of Geophysical Research, v. 111, B05205, 24 p., https://doi. org/10.1029/2005JB003876.

Sherrod, D.R., Izuka, S.K., and Cousens, B.L., 2015, Onset of rejuvenated-stage volcanism and the formation of Līhu' $\mathrm{e}$ basin-Kaua'i events that occurred 3-4 million years ago, chap 6 of Carey, R.J., Cayol, V., Poland, M.P. and Weis, D., eds., Hawaiian volcanoes-from source to surface: American Geophysical Union Monograph 208, p. 105-123, doi:10.1002/9781118872079.ch6.

Sherrod, D.R., Murai, T., and Tagami, T., 2007a, New K-Ar ages for calculating the end-of-shield extrusion rates at West Maui volcano, Hawaiian island chain: Bulletin of Volcanology, v. 69, no. 6, p. 627-642.

Sherrod, D.R., Nishimitsu, Y., and Tagami, T., 2003, New K-Ar ages and the geologic evidence against rejuvenated-stage volcanism at Haleakalā, East Maui, a postshield-stage volcano of the Hawaiian island chain: Geological Society of America Bulletin, v. 115, no. 6, p. 683-694.

Sherrod, D.R., Sinton, J.M., Watkins, S.E., and Brunt, K.M., 2007b, Geologic map of the State of Hawaii: U.S. Geological Survey Open-File Report 2007-1089, 83 p., 8 plates, scales 1:100,000 and 1:250,000, with GIS database, https:// pubs.usgs.gov/of/2007/1089/.

Singer, B.S., Hoffman, K.A., Chauvin, A., Coe, R.S., and Pringle, M.S., 1999, Dating transitionally magnetized lavas of the late Matuyama Chron: toward a new ${ }^{40} \mathrm{Ar} /{ }^{39} \mathrm{Ar}$ timescale of reversals and events: Journal of Geophysical Research, v. 104, no. B1, p. 679-693.

Singer, B.S., and Pringle, M.S., 1996, Age and duration of the Matuyama-Brunhes geomagnetic polarity reversal from ${ }^{40} \mathrm{Ar} /{ }^{39} \mathrm{Ar}$ incremental heating analyses of lavas: Earth and Planetary Science Letters, v. 139, nos. 1-2, p. 47-61.

Sinton, J.M., 1987, Revision of stratigraphic nomenclature of Waianae volcano, Oahu, Hawaii: U.S. Geological Survey Bulletin 1775-A, p. A9-A15.

Sinton, J.M., 2005, Geologic mapping, volcanic stages and magmatic processes in Hawaiian volcanoes [abs.]: Eos (American Geophysical Union Transactions), v. 86, no. 52, Fall meeting supplement, V51A-1471.

Sinton, J.M., Diller, D.E., and Chen, C.-Y., 1987, Trip 3, geology and petrological evolution of West Maui volcano, in Sinton, J.M., ed., Field trip guide to Maui: Geological Society of America Cordilleran section meeting, 83rd, May 20-22, Hilo, Hawaii, p. 13-30.

Sinton, J.M., Eason, D.E., and Duncan, R.A., 2017, Volcanic evolution of Moloka'i, Hawai'i-implications for the shield to postshield transition in Hawaiian volcanoes: Journal of Volcanology and Geothermal Research, v. 340, p. 30-51.

Sinton, J.M., Eason, D.E., Tardona, M., Pyle, D., van der Zander, I., Guillou, H., Clague, D.A., and Mahoney, J.J., 2014, Ka'ena volcano - a precursor volcano of the island of O'ahu, Hawai'i: Geological Society of America Bulletin, v. 126, nos. 9-10, p. 1219-1244, https://doi.org/10.1130/B30936.1.

Sinton, J.M., and Rowland, S.K., 1997, Petrology and volcanology of Maui, in Batiza, R., Lee, P., and McCoy, F., Molokai and Lanai, Maui, and Hawaii: Geological Society of America Cordilleran section meeting, 93rd, May 21-23, Kailua-Kona, Hawaii, p. 1-19.

Sinton, J.M., and Sinoto, Y.H., 1997, A geochemical database for Polynesian adze studies, in Weisler, M.I., ed., Prehistoric long-distance interaction in Oceania_-an interdisciplinary approach: New Zealand Archaeological Association Monograph 21, p. 194-204. 
Sisson, T.W., Lipman, P.W., and Naka, J., 2002, Submarine alkalic through tholeiitic shield-stage development of Kīlauea volcano, Hawai'i, in Takahashi, E., Lipman, P.W., Garcia, M.O., Naka, J., and Aramaki, S., eds., Hawaiian volcanoes_-deep underwater perspectives: American Geophysical Union Geophysical Monograph 128, p. 193-219.

Smith, J.R., Satake, K., Morgan, J.K., and Lipman, P.W., 2002, Submarine landslides and volcanic features on Kohala and Mauna Kea volcanoes and the Hana Ridge, Hawaii, in Takahashi, E., Lipman, P.W., Garcia, M.O., Naka, J., and Aramaki, S., eds., Hawaiian volcanoes-deep underwater perspectives: Washington, D.C., American Geophysical Union, Geophysical Monograph 128, p. 11-28.

Spengler, S.R., and Garcia, M.O., 1988, Geochemistry of the Hawi lavas, Kohala Volcano, Hawaii: Contributions to Mineralogy and Petrology, v. 99, p. 90-104.

Stearns, H.T., 1938, Ancient shore lines on the island of Lanai, Hawaii: Geological Society of America Bulletin, v. 49, p. 615-628.

Stearns, H.T., 1939, Geologic map and guide of the Island of Oahu, Hawaii: Hawaii Division of Hydrography, Bulletin 2, scale 1:62,500.

Stearns, H.T., 1940a, Geology and ground-water resources of the islands of Lanai and Kahoolawe, Hawaii: Hawaii Division of Hydrography, Bulletin 6, part 1, p. 1-60.

Stearns, H.T., 1940b, Geology and ground-water resources of the islands of Lanai and Kahoolawe, Hawaii: Hawaii Division of Hydrography, Bulletin 6, part 2, p. 117-147.

Stearns, H.T., 1940c, Supplement to the geology and groundwater resources of the island of Oahu, Hawaii: Hawaii Division of Hydrography, Bulletin 5, p. 1-55.

Stearns, H.T., 1946, Geology of the Hawaiian Islands: Hawaii Division of Hydrography, Bulletin 8, 106 p.

Stearns, H.T., 1947, Geology and ground-water resources of the island of Niihau, Hawaii. Hawaii Division of Hydrography, Bulletin 12, part 1, p. 1-38.

Stearns, H.T., 1970, Ages of dunes on Oahu, Hawaii: Honolulu, Hawaii, Occasional Papers of Bernice P. Bishop Museum, v. 24, no. 4, p. 49-72.

Stearns, H.T., 1978, Quaternary shorelines in the Hawaiian Islands: Bernice P. Bishop Museum Bulletin 237, 57 p.

Stearns, H.T., and Dalrymple, G.B., 1978, The K-Ar age of the Black Point dike on Oahu, Hawaii, and its relation to the Yarmouth interglaciation: Occasional Papers of Bernice P. Bishop Museum, v. 24, no. 16, p. 307-313.

Stearns, H.T., and Macdonald, G.A., 1942, Geology and ground-water resources of the island of Maui: Hawaii Division of Hydrography Bulletin 7, 344 p.

Stearns, H.T., and Macdonald, G.A., 1946, Geology and ground-water resources of the island of Hawaii: Hawaii Division of Hydrography Bulletin 9, 363 p.

Stearns, H.T., and Macdonald, G.A., 1947, Geology and ground-water resources of the island of Molokai, Hawaii: Hawaii Division of Hydrography Bulletin 11, 113 p.

Stearns, H.T., and Vaksvik, K.N., 1935, Geology and groundwater resources of the island of Oahu, Hawaii: Hawaii Division of Hydrography Bulletin 1, 479 p.
Steiger, R.H., and Jäger, E., 1977, Convention on the use of decay constants in geo- and cosmochronology: Earth and Planetary Science Letters, v. 36, p. 359-362.

Stuiver, M., and Reimer, P.J., 1993, Extended ${ }^{14} \mathrm{C}$ database and revised CALIB radiocarbon calibration program, Radiocarbon 35:215-230. [Program ver. 5.0.1, copyright 2005, available online at http://radiocarbon.pa.qub.ac.uk/calib, accessed February 2006.]

Swanson, D.A., Duffield, W.A., and Fiske, R.S., 1976, Displacement of the south flank of Kilauea volcano: the result of forceful intrusion of magma into the rift zones: U.S. Geological Survey Professional Paper 963, 39 p.

Swanson, D.A., Fiske, R.S., and Rose, T., 2002, Explosive eruptions at Kilauea [abs.]: American Association for the Advancement of Science, Pacific Division Proceedings, Program with Abstracts [83rd annual meeting, Waimea, Hawaii, June 12-16, 2002], v. 21, pt. 1, p. 52.

Swanson, D.A., McGeehin, J.P., Rose, T.R., and Fiske, R.S., 2004, Age of the Keanakako 'i Ash, Kilauea Volcano [abs.]: Eos (Transactions of the American Geophysical Union), v. 85, no. 28 , abs. no. V33A-88.

Swanson, D.A., Rose, T.R., Fiske, R.S., and McGeehin, J.P., 2012, Keanakāko'i Tephra produced by 300 years of explosive eruptions following collapse of Kîlauea's caldera in about 1500 CE: Journal of Volcanology and Geothermal Research, v. 215-216, p. 8-25.

Swanson, D.A., Rose, T.R., Mucek, A.E., Garcia, M.O., Fiske, R.S., and Mastin, L.G., 2014, Cycles of explosive and effusive eruptions at Kîlauea Volcano, Hawai' $\mathrm{i}$ : Geology, v. 42, no. 7, p. 631-634, https://doi.org/10.1130/G35701.1.

Tagami, T., Nishimitsu, Y., and Sherrod, D.R., 2003, Rejuvenated-stage volcanism after 0.6-m.y. quiescence at West Maui volcano, Hawaii-new evidence from K-Ar ages and chemistry of Lahaina Volcanics: Journal of Volcanology and Geothermal Research, v. 120, p. 207-214.

Taylor, J.R., 1982, An introduction to error analysis: Mill Valley, Calif., University Science Books, 270 p.

Teanby, N., Laj, C., Gubbins, D., and Pringle, M., 2002, A detailed palaeointensity and inclination record from drill core SOH1 on Hawaii: Physics of the Earth and Planetary Interiors, v. 131, p. 101-140.

Trusdell, F.A., Novak, E., and Evans, S.R., 1992, Core lithology, State of Hawaii Scientific Observation Hole 4, Kilauea volcano, Hawaii: U.S. Geological Survey OpenFile Report 92-586, 72 p.

Trusdell, F.A., Novak, E., Evans, S.R., and Okano, K., 1999, Core lithology from the State of Hawaii Scientific Observation Hole 1, Kilauea Volcano, Hawai'i: U.S. Geological Survey Open-File Report 99-389, 67 p.

Trusdell, F.A., and Swannell, P., 2003, Explosive deposits on Mauna Loa [abs.]: Cities on Volcanoes 3, Abstracts volume, Hilo, Hawaii, July 14-18, 2003, p. 135.

Trusdell, F.A., Wolfe, E.W., and Morris, J., 2006, Digital database of the geologic map of the Island of Hawai' $\mathrm{i}$ : U.S. Geological Survey Data Series 144, ver. 1.0, accessed March 2006, at http://pubs.usgs.gov/ds/2005/144/.

University of Chicago Press, 2003, The Chicago Manual of Style, 15th ed.: Chicago, University of Chicago Press, 956 p. 
Van der Zander, I., Sinton, J.M., and Mahoney, J.J., 2010, Late shield-stage silicic magmatism at Wai'anae VolcanoEvidence for hydrous crustal melting in Hawaiian volcanoes: Journal of Petrology, v. 51, p. 671-701, https://doi. org/10.1093/petrology/egp094.

Walker, G.P.L., 1987, The dike complex of Koolau volcano, Oahu: internal structure of a Hawaiian rift zone: U.S. Geological Survey Professional Paper 1350, v. 2, p. 961-993.

Walker, G.P.L., 1990, Kalaupapa and Mokuhooniki, Molokai, Hawaii, in Wood, C.A., and Kienle, Jürgen, eds., Volcanoes of North America: Cambridge, Cambridge University Press, p. 330-331.

Walker, G.P.L., 1995, Plant molds in Hawaiian basalts; was Oahu a desert, and why?: Journal of Geology, v. 103, p. 85-93.

Walker, G.W., 1969, Geologic map of the Kau Desert quadrangle, Hawaii: U.S. Geological Survey Geologic Quadrangle Map GQ-827, scale 1:24,000.

Washington, H.S., 1923, Petrology of the Hawaiian Islands; I, Kohala and Mauna Kea, Hawaii: American Journal of Science, v. 5, p. 465-502.

Washington, H.S., and Keyes, M.G., 1926, Petrology of the Hawaiian Islands; V, the Leeward Islands: American Journal of Science, v. 12, p. 336-352.

Webster, J.M., Clague, D.A., Braga, J.C., Spalding, H., Renema, W., Kelley, C., Applegate, B., Smith, J.R., Paull, C.K., Moore, J.G., and Potts, D., 2006, Drowned coralline algal dominated deposits off Lanai, Hawaii; carbonate accretion and vertical tectonics over the last $30 \mathrm{ka}$ : Marine Geology, v. 225 , p. 223-246.

Weisler, M., 2011, A quarried landscape in the Hawaiian Islands: World Archaeology, v. 43, no. 2, p. 298-317.

Wentworth, C.K., and Winchell, H., 1947, Koolau Basalt Series, Oahu, Hawaii: Geological Society of America Bulletin, v. 58, p. 49-77.

West, H.B., 1988, The origin and evolution of lavas from Haleakala Crater, Hawaii: Houston, Texas, Rice University, Ph.D. dissertation, 351 p.

West, H.B., Garcia, M.O., Gerlach, D.C., and Romano, J., 1992, Geochemistry of tholeiites from Lanai, Hawaii: Contributions to Mineralogy and Petrology, v. 112, p. 520-542.
West, H.B., and Leeman, W.P., 1987, Isotopic evolution of lavas from Haleakala Crater, Hawaii: Earth and Planetary Science Letters, v. 84, p. 211-225.

West, H.B., and Leeman, W.P., 1994, The open-system geochemical evolution of alkalic cap lavas from Haleakala Crater, Hawaii, USA: Geochimica et Cosmochimica Acta, v. 58 , no. 2 , p. 773-796.

Wilkinson, J.F.G., and Stolz, A.J., 1983, Low-pressure fractionation of strongly undersaturated alkaline ultrabasic magma: the olivine-melilite-nephelinite at Moiliili, Oahu, Hawaii: Contributions to Mineralogy and Petrology, v. 83, p. 363-374.

Winchell, H., 1947, Honolulu series, Oahu, Hawaii: Geological Society of America Bulletin, v. 58, p. 1-48.

Wolfe, E.W., and Morris, J., 1996a, Geologic map of the Island of Hawaii: U.S. Geological Survey Miscellaneous Investigations Series I-2524-A, scale 1:100,000.

Wolfe, E.W., and Morris, J., 1996b, Sample data for the geologic map of the Island of Hawaii: U.S. Geological Survey Miscellaneous Investigations Series I-2524-B, scale $1: 100,000$.

Wolfe, E.W., Wise, W.S., and Dalrymple, G.B., 1997, The geology and petrology of Mauna Kea Volcano, HawaiiA study of postshield volcanism: U.S. Geological Survey Professional Paper 1557, 129 p.

Woodcock, A.H, 1974, Permafrost and climatology of a Hawaii volcano crater: Arctic and Alpine Research, v. 6, no. 1, p. 49-62.

Woodcock, A.H., Rubin, M., and Duce, R.A., 1966, Deep layer of sediments in alpine lake in the tropical mid-Pacific: Science, v. 154, no. 3749, p. 647-648.

Xu, G., Frey, F. A., Clague, D. A., Weis, D., and Beeson, M. H., 2005, East Molokai and other Kea-trend volcanoes; magmatic processes and source as they migrate away from the Hawaiian hot spot: Geochemistry, Geophysics, Geosystems $\left(\mathrm{G}^{3}\right)$, v. 6, no. 5, 28 p, https://doi.org/10.1029/2004GC000830.

Yoder, H.S., Jr., and Tilley, C.E., 1962, Origin of basalt magmas: an experimental study of natural and synthetic rock systems: Journal of Petrology, v. 3, no. 3, p. 342-532.

Zbinden, E.A., and Sinton, J.M., 1988, Dikes and the petrology of Waianae Volcano, Oahu: Journal of Geophysical Research, v. 93, no. B12, p. 14856-14866. 


\section{Appendix 1. Information About the Recalculating of Radiometric Ages for Hawai' $i$ State Geologic Map}

Data for radiometric ages were compiled from the published literature. Some additional data were obtained from unpublished sources and are newly presented here. To simplify the tabulation, we report the weighted mean age in those instances where multiple gas extractions led to multiple age determinations from single samples. Ages are weighted by the inverse of the variance (Taylor, 1982).

Decay standards and isotopic abundances used in calculating K-Ar ages were standardized in 1977 (Steiger and Jäger, 1977). For consistency, all ages were checked by recalculation, and revised ages are reported here. Consequently, our tabulation might appear discrepant if a reader makes only a casual comparison of previously published ages for specific samples. Described here, in chronologic order, are specific examples of changes made for those publications that preceded the complete adoption of the new standards.

Evernden and others, 1964-Data are insufficient to allow recalculation. Therefore, we used the method of Dalrymple (1979), which leads to ages about two percent older than originally reported by Evernden and colleagues.

McDougall, 1964-All ages were recalculated using data originally published. No analytical error was assigned to specific ages in the original document, but an estimation for $2 \sigma$ error was provided - (1) about 3 percent of the reported age where the proportion of radiogenic to atmospheric argon exceeds 15 percent and (2) 5-10 percent for radiogenic argon less than 15 percent (McDougall, 1964, p. 111). We used 3 percent and 10 percent for the two cases, respectively.

Gramlich and others, 1971—Recalculated using modern decay constants. Weighted mean ages were estimated for those samples that had multiple gas extractions.
McDougall and Aziz-ur-Rahman, 1972—Ages recalculated here using the data originally published. Samples had multiple gas extractions; therefore, we assigned the original $1 \sigma$ error to our newly recalculated age and then determined the weighted mean age reported in our database. Additionally, some earlier ages, which were first reported without analytical error (McDougall, 1964), appeared in the 1972 report with $1 \sigma$ analytical error, which we adopted.

McDougall and Swanson, 1972—Recalculated using modern decay constants. Weighted mean ages were estimated for the three samples that had multiple gas extractions.

Doell and Dalrymple, 1973 — Recalculated using modern decay constants. Weighted mean ages were estimated for those samples that had multiple gas extractions.

Bonhommet and others, 1977-Recalculated using modern decay constants. Weighted mean ages were estimated for those samples that had multiple gas extractions.

Stearns and Dalrymple, 1978 - Used modern decay constants. No changes reported here.

McDougall, 1979—Used modern decay constants. No changes reported here.

Lanphere and Dalrymple, 1980 - The reported decay constants reported therein differ from modern values, but the data are unchanged by our efforts at recalculating.

Naughton and others, 1980 — Used modern decay constants. No changes reported here.

After 1980, the next publication describing K-Ar ages was issued in 1982 (Clague and others, 1982). It and all subsequent publications use modern decay standards for calculating ages. 